\title{
La Villita Earthworks (41BX677): San Antonio, Texas A Preliminary Report of Investigations of Mexican Siege Works at the Battle of the Alamo
}

Joseph H. Labadie

Follow this and additional works at: https://scholarworks.sfasu.edu/ita

Part of the American Material Culture Commons, Archaeological Anthropology Commons, Environmental Studies Commons, Other American Studies Commons, Other Arts and Humanities Commons, Other History of Art, Architecture, and Archaeology Commons, and the United States History Commons

Tell us how this article helped you.

This Article is brought to you for free and open access by the Center for Regional Heritage Research at SFA ScholarWorks. It has been accepted for inclusion in Index of Texas Archaeology: Open Access Gray Literature from the Lone Star State by an authorized editor of SFA ScholarWorks. For more information, please contact cdsscholarworks@sfasu.edu. 


\section{La Villita Earthworks (41BX677): San Antonio, Texas A Preliminary Report of Investigations of Mexican Siege Works at the Battle of the Alamo}

\section{Creative Commons License}

\section{(c) (1) \&}

This work is licensed under a Creative Commons Attribution-NonCommercial 4.0 International License 


\section{LA VILLITA EARTHWORKS}

(41 BX 677): San Antonio, Texas

A Preliminary Report of Investigations of Mexican Siege Works at the Battle of the Alamo

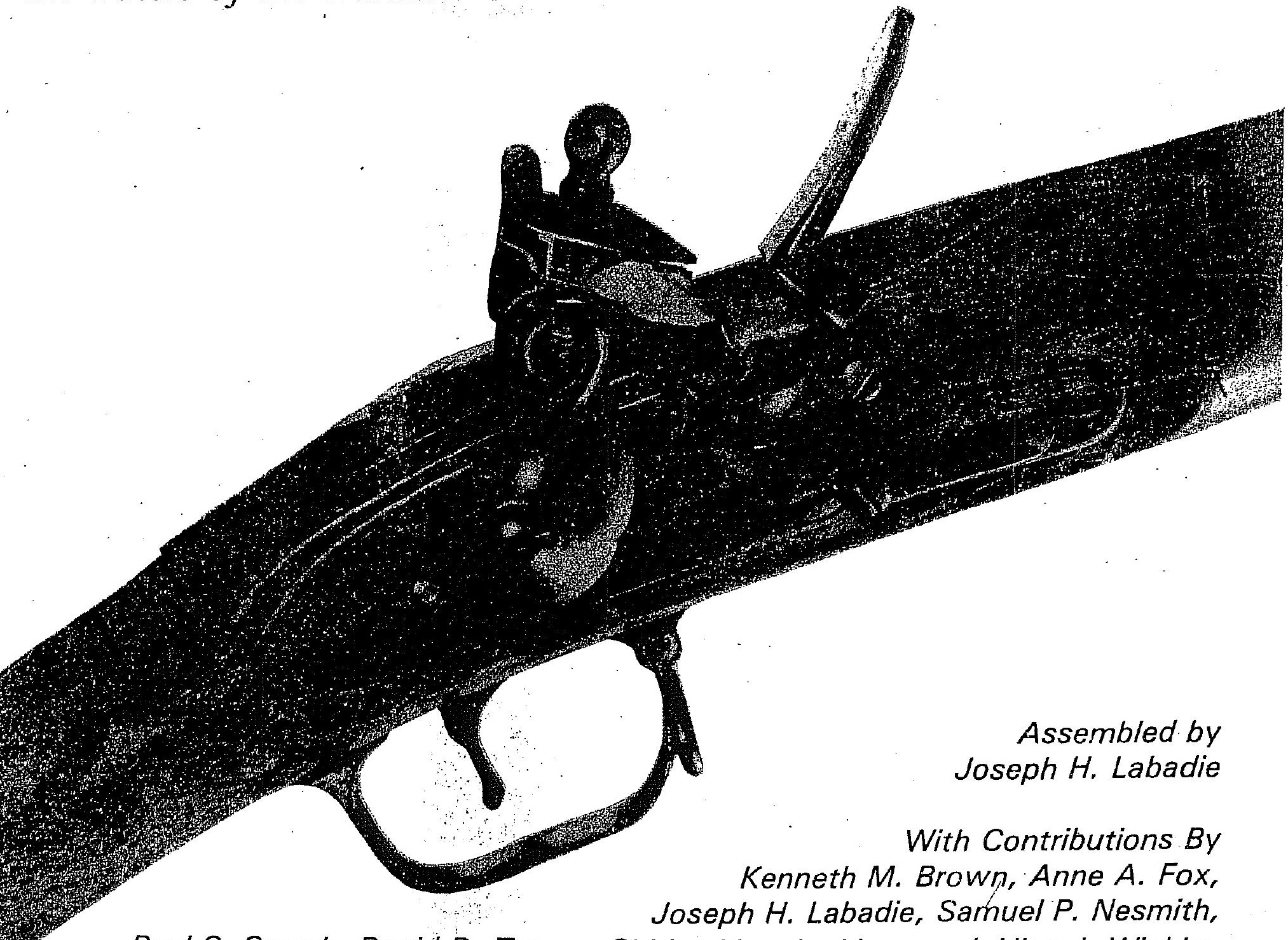

Paul S. Storch, David D. Turner, Shirley Van der Veer, and Alisa J. Winkler

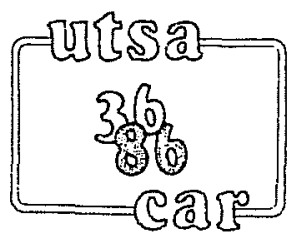

Center for Archaeological Research The University of Texas at San Antonio Archaeological Survey Report, No. 159 1986

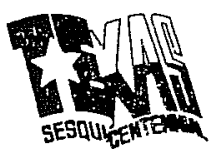

(C) 1981 State of Texas 

COVER ILLUSTRATION: Lock from India Pattern Brown Bess musket (ca. 1809-1815), typical of those carried by the Mexican infantry at the battle of the $A$ lamo. Cover iliustration by Kerineth M. Brown. 

A Preliminary Report of Investigations of Mexican Siege Works at the Battle of the Alamo

Assembled by Joseph H. Labadie

With contributions by

Kenneth M. Brown, Anne A. Fox, Joseph H. Labadie, Samuel P. Nesmith, Paul S. Storch, David D. Turner, Shirley Van der Veer, and Al isa J. Winkler

Texas Antiquities Committee Permit No. 480

Thomas R. Hester, Principal Investigator

Center for Archaeological Research The University of Texas at San Antonio Archaeological Survey Report, No. 159 
The following information is provided in accordance with the General Rules of Practice and Procedure, Chapter 41.11 (Investigative Reports), Texas Antiquities Committee:

1. Type of investigation: monitoring of foundation excavations for the relocation of the Fairmount Hotel;

2. Project name: Fairmount I Project;

3. County: Bexar;

4. Principal investigator: Thomas R. Hester; comprincipal investigator: Jack D. Eaton;

5. Name and 1ocation of sponsoring agency: Alamo Architects, San Antonio, Texas;

6. Texas Antiquities Committee Permit No. 480;

7. Published by the Center for Archaeological Research, The University of Texas at San Antonio 78285-0658, 1986.

A 1 ist of publications offered by the Center for Archaeological Research can be obtained by sending $\$ 1.00$ to the Center for Archaeological Research, The University of Texas at San Antonio, San Antonio, Texas 78285-0658. 


\section{ABSTRACT}

La Villita Earthworks is located in the heart of downtown San Antonio, Texas. The site appears to have been formed initially in 1 ate February 1836, by Mexican soldiers with General Santa Anna's invading forces during the second battle of the Alamo. The outcome of this battle has been the topic for 1 itera $17 y$ thousands of books over the past 149 years. Now, for the first time, archaeological evidence has been discovered which provides the first real glimpse at the Mexican side of the battle of the Alamo. The ramifications of the discovery are yet to be fully realized. Military historians and other scholars now have material evidence from the actual battle by which to evaluate the accuracy of the several eyewitness accounts of the battle. For archaeologists, the site represents the most comprehensive look yet afforded at San Antonio during this famous period. 


\section{TABLE OF CONTENTS}

ABSTRACT . . . . . . . . . . . . . . . . . . . . . . .

LIST OF FIGURES . . . . . . . . . . . . . . . . . . .

LIST OF TABLES ... . . . . . . . . . . . . . . . . . . .

ACKNOWLEDGMENTS ...........................

CHAPTER 1: PROJECT OVERVIEW (Joseph H. Labadie) . . . . . . . . . .

Introduction .................... 1

Phase I Investigations (Monitoring Program) . . . . . . . 2

Phase II Investigations (Shove1 Test Program) . . . . . 3

Phase II Investigations (Controlled Excavation) . . . . . 6

Field Recording System (Shirley Van der Veer) . . . . . . 6

CHAPTER 2: HISTORICAL AND ARCHIVAL RESEARCH (Joseph H. Labadie) • • • 9

Introduction . . . . . . . . . . . . . . . . . 9 9

Problems Associated With Archival Research in San Antonio - 11

Spanish Missions and Colonizing Period (1528-1800) . . . . . 12

Anglo-American and European Colonization of Texas

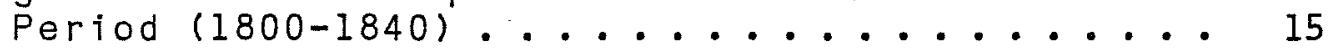

The Republic of Texas Period $(1836-1846) \ldots . . . . . . .17$

Texas in the Lone Star State Period (1846-1861) . . . . . 19

Victorian Texas Period (1874-1901) . . . . . . . . . 19

Summary and Conclusions ................. 21

References Cited................... 25

CHAPTER 3: STRUCTURE AND STRATIGRAPHY OF THE SITE (Kenneth M. Brown) $\quad 28$

Geologic Setting................ 28

Location of the Site................ 28

Layout of the Earthworks ............... 29

Stratigraphy of the Ditch Fill ............. 33

Features: Intrusive and Otherwise . . . . . . . . 37

The Sequence of Events Recorded by the Ditch Fill . . . . 44

19th-Century Conventional Field Fortification . . . . . . 45

Fortifications in the First Battle of the Alamo . . . . . 48

Siege Fortifications in the Second Battle of the Alamo . . . 53

Fortifications During the Woll Invasion, 1842 . . . . . 55

Function of the Site................ 55

Summary and Conclusions............... 57

Acknowledgments ................ 58

References Cited . . . . . . . . ......... 58

CHAPTER 4: ANALYSIS OF MILITARY RELATED ARTIFACTS (Samuel P. Nesmith) . 62

Introduction ................... 62

Historical Background . . . . . . . . . . . . . 62

Artillery Projectiles . . . . . . . . . . . 63

Smal1 Arms Ammunition............... 64

Firearms Parts .. . . . . . . . . . . . . 65

Edged Weapons................... 67

Horse Equipment . . . . . . . . . . . . . . 68

Personal Items . . . . . . . . . . . . . 70

Description of the Military Artifacts . . . . . . . 73

Summary and Conclusions . . . . . . . . . . . . 100

References Cited... . . . . . . . . . . . 103 
CHAPTER 5: CERAMICS (Anne A. Fox) ............ 107

Introduction ............... 107

Soft Paste Earthenwares ............. 109

Unglazed Earthenwares ............. 109

Burnished Earthenwares ............ 111

Lead-Glazed Earthenwares ........... 111

Tin-G1 azed Earthenwares ............ 111

Hard Paste Earthenwares .............. 111

Refined Earthenwares ............. 111

Lusterwares ................. . . . 122

Yellow Ware........................ 122

Porcelain ................... 122

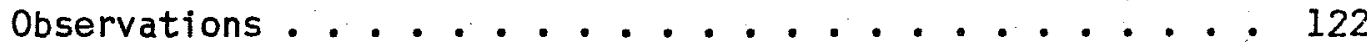

Conclusions . . . . . . . . . . . . . . 126

References Cited ................. 127

CHAPTER 6: PRELIMINARY ANALYSIS OF FAUNAL REMAINS (ATisa J. WinkTer) , 128

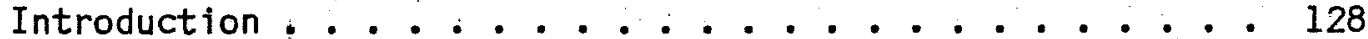

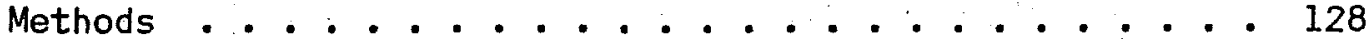

Description of Taxa ......................... 131

Butchering Patterns .............. . . 133

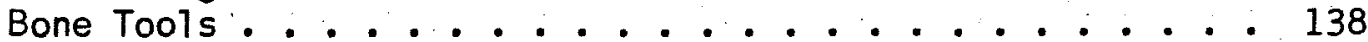

Discussion and Conclusions............... 138

References Cited ................ . . 139

CHAPTER 7: GLASS ARTIFACTS (David D. Turner) .......... 140

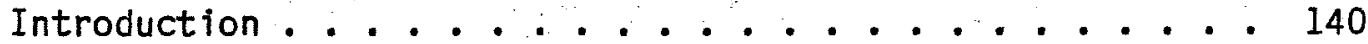

Background ................... . . 140

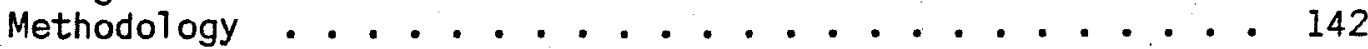

Description and Discussion of Glass Artifacts . . . . . 148

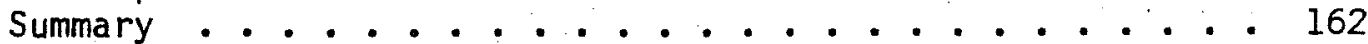

Conclusions ..................... 168

References Cited . . . . . . . . . . . . . . . 169

CHAPTER 8: CONSERVATION REPORT (PauT S. Storch) .......... 172

Introduction ................. 172

The Artifacts ................. . . 172

Analysis ............................... 173

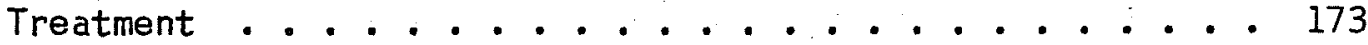

Conciusions .................. 174

Acknowledgments ............... 177

CHAPTER 9: CONCLUDING REMARKS (Kenneth M. Brown) . . . . . . . 178

References Cited.............. 181 


\section{LIST OF FIGURES}

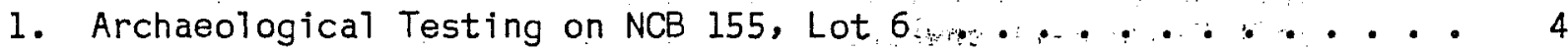

2. Location of the Phase II Shovel Tests and Hand-Excavated Units on the Northern Portion of NCB 155, Lot $6 \ldots . . . . . . .25$

3. Location of La Villita Earthworks (4I BX 677) on the Northern Half of NCB 155, Lot 6........................... 10

4. Early Labores and Barrios of San Antonio During the Early.

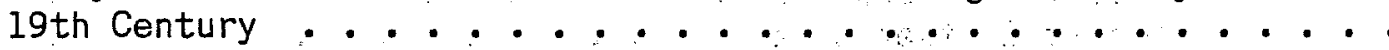

5. New City Block Numbers in the Vicinity of La Vilitita Historical District in Downtown San Antonio, Texas . . . . . . . 18

6. A Portion of Koch's 1886 Bird's Eye View Map of San Antonio Which Depicts a Structure at the Corner of East Nueva and South Alamo Streets .................... 20

7. Aerial View of La Villita Historical District in $1939 \ldots . . . . . . .22$

8. Schematic Section of the Site, Looking North . . . . . . 30

9. Profile of Part of North Face of Island, Looking South ..... . 31

10. Profile Along Egg Line, Looking West ........... 32

11. Plan of Excavations ......................... 39

12. Feature 1 , Hearth ........................... 40

13. Profile of Part of North Face of Island; View of Feature 4 (Stone Foundation and Footing Trench) ........... 42

14. Map Showing Location of Mexican Entrenchments During the First and Second Battles of the Alamo, Along with Other Key Points . . 51

15. Part of a Manuscript Map by Dr. Morgan W. Merrick (1853), Entitled "Rout of Johnson + Milam's Columns from Mol ino Blanco

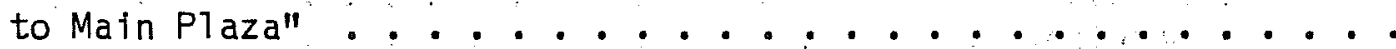

16. Diagram of the Brown Bess Musket Detailing the Location of its

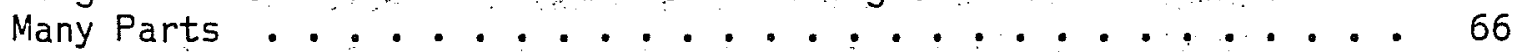

17. Diagram of a Brown Bess Bayonet . . . . . . . . . . . . 67

18. Nomenclature of a Sword and Hilt . . . . . . . . . . . . 69

19. Diagram of a 19th-Century Horseshoe . . . . . . . . . . . 71

20. 19th-Century Military Button Types ............... 72

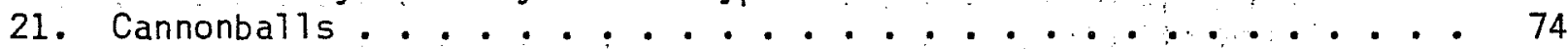

22. Lead Balls ........................... 76

23. Gunflints and Lead Pads . . . . . . . . . . . . . 79

24. Schematic Diagram of the Lock Plate for a Brown Bess Flintlock Musket ..................... 82

25. Musket Hardware . . . . . . . . . . . . . . . 85

26. Knife Blades and Sword Guard . . . . . . . . . . . . 87

27. Knife Blades and Possible Sword Blades . . . . . . . . . 89

28. Bayonets and Possible Pike Head . . . . . . . . . . . . . 91

29. Horse Equipment . . . . . . . . . . . . . . . . 95

30. Butt Plate, Spur Rowel, and Stirrup.............. 97

31. Buttons, Hooks, and Buckles . . . . . . . . . . . . . . . . 99

32. Level Concordance, With Ceramic Cross-Mends . . . . . . . . . 110

33. Soft Paste Earthenwares . . . . . . . . . . . . . . . . . 113

34. Burnished and Tin-Giazed Earthenwares . . . . . . . . . . 115

35. Lead-Glazed Earthenware Sherds from Two Different "Chocolatera"

Vessels . . . . . . . . . . . . . . . . . 116

36. Refined Earthenwares (Banded S1 ip and Mocha) . . . . . . . . 119

37. Lusterwares and Refined Earthenwares (Transfer-Printed Pearlwares). 121

38. Range and Variation in Edge-Decorated Davenport Plates . . . . 123 
39. Back Stamps and Importers' Marks Which Date from 1830 to 1850 . . 125

40. Partially Excavated Bone Bed in Excavation Units $C$ and $D$ at

La Villita Earthworks . . . . . . . . . . . . . . . . 129

41. Selected Faunal Remains . . . . . . . . . . . . . . . 135

42. Examples of Butchered Bos taurus Bones . . . . . . . . . . . . 136

43. Common Neck/Lip Treatments . . . . . . . . . . . . . . . . 147

44. Basal Fragments . . . . . . . . . . . . . . . . . . . . 151

45. Clear and Black Basal Fragments . . . . . . . . . . . . . . 153

46. BIM Fragments and Slug Plate Tag . . . . . . . . . . . . . . 157

47. Neck/Mouth Fragments (Category B) . . . . . . . . . . . . 161

48. Tablewares and Miscellaneous Items . . . . . . . . . . . . . 165

49. Options for Treating Corroded Metal . . . . . . . . . . . . . 175

50. Specimens After Treatment . . . . . . . . . . . . . . 176

\section{LIST OF TABLES}

1. Temporal Subdivisions as Defined by the State Historical Resources Inventory (1966) . . . . . . . . . . . . . . . . . . 11

2. Compilation of Known Deed Records and Businesses Located on

NCB 155, Lot 6 . . . . . . . . . . . . . . 23

3. Provenience of Ceramic Sherds in Units J, C, D, M, and U . . . . 108

4. Record of Cross-Mending of Ceramic Sherds . . . . . . . . . . . 109

5. Summary of Information on Refined Earthenwares from 41 BX 677 . . . 117

6. Faunal List and Specimen Information . . . . . . . . . . . . 130

7. Skeletal Composition of Bos, Including Probable Bos (Bos/Equus)

Remains, with Percentage Burned and Butchered . . . . . . . . . 132

8. Glass Artifacts Recovered from 41 BX 677 . . . . . . . . . . . . 163

9. Glass Artifacts Selected for Analysis . . . . . . . . . . . 166 


\section{ACKNOWLEDGMENTS}

The Fairmount I Project provided a unique set of circumstances and problems which were met by an equally unique set of individuals. Over 1300 man-hours were expended during the field work, with 12-hour days routine. On the final day of field work the crew put in a 17-hour day, working from morning's first light until after midnight. The rains, mud, curious pedestrians, and constant media attention from newspaper, radio, and television reporters had 1 ittle effect on the progress of the excavations made by the 63 peop 1 e who worked on the eight-day project.

The success of this project is due solely to the many dedicated individuals who volunteered their time (and paid their own expenses) to help save this unique piece of San Antonio's colorful history.

The project leaves many people to thank; I apologize for any oversights. Deserving of special thanks are the staff at the Center for Archaeological Research at The University of Texas at San Antonio: Dr. Thomas R. Hester, Anne A. Fox, Kenneth M. Brown, Lynn Highley, Jeff Huebner, David Hafernik, Roger Wayne Johnson, Ray Smith, Sylvia Reyna, Beth Craig, Ralph Snavely, Martha Morgan, Frances Meski11, Kay Hindes, Anne Kerr, I. Waynne Cox, A. J. Taylor, Bob Harrison, Joe Tovar, Dr. Joel Gunn, and A1 McGraw.

Anthropology students from The University of Texas at San Antonio involved in the project were Linda Wooten, David Turner, Debbie King, Adrian Garcia, Bruce Mergele, Cathy Dodt, Janet Steele, Rita Neurether, James E11 is, Don McEwan, and Wilson Mckinney

The bulk of volunteer excavators came from the Southern Texas Archaeological Association (STAA) and the Texas Archeological Society (TAS). It was Shirley $V$ an der Veer, treasurer of the STAA, who single-handed $1 y$ contacted nearly a 11 the volunteers, and coordinated work loads and work schedules. STAA and TAS volunteers during the project were Santiago Escobedo, Lenora Metting, Kathy Labadie, Mike Gibbons, Herb Al 1 ison, Harry Crouse, C. K. Chandler, Tom Mil1 1 er, Cecil Pee1, Dortha Pee1, Shirley Van der Veer, W. R. Van der Veer, Kate Vaught, Dar 1a Cox, Heidi Mitche1 1, and Judy Crouse. Other volunteer excavators were Mike MCGlone, Ann MCGlone, Elizabeth Ethridge-Huebner, Sarah Schwartz, Rich Langdon, Rhonda Bridges, Fern Brady, Dan Agler, Robert Wilkes, Bridget Smart, Scott Highley, Fred Oglesby, Ken and Nancy Graham, and Drew Van Steenburg.

Special thanks are also due to the Fairmount Hotel developers, Belton $\mathrm{K}$. Johnson, C. Thomas Wright, and Virginia Van Steenburg, who provided us with a 25- $\times$ 25-foot canopy tent to protect the excavations from the frequent rains. They also provided the electric generator, lights, hot coffee, and food necessary to complete excavations of the final day of work.

A thank you is also extended to Mike McGlone (Alamo Architects), Frank Perry (City of San Antonio, Special Projects Officer), the San Antonio Police Department, and the Bexar County Sheriff's Department for increased patrols in the vicinity of the site during nighttime hours, Guido Construction Company (Jonnie Sirianni) for the use of equipment and storage facilities, the Four Seasons Hotel (John Indrieri and Chester Hoyack) for several elegant 
1 unches and use of their parking facilities, Holly Morgan (Witte Museum) for initial faunal identifications, and Dr. LaVerne Herrington (Texas Historical Commission) for her frequent visits and keen interest in the progress of the excavations.

The project is also indebted to those individuals who dug through the archives while others dug through dirt; they include: Bernice Strong and Sharon Crutchfield (Daughters of the Republic of Texas Research Library), John Leal (Bexar County Courthouse Deed Records), and Bruce Mergele (UTSA graduate internist at the San Antonio Historic Preservation Office). We would also like to gratefully acknowledge the permission by Sharon Crutchfield and the Daughters of the Republic of Texas to reproduce the Merrick manuscript map as Figure 15. Richard Garay, an independent researcher, provided invaluable assistance and shared information from his own research on a Spanish colonial structure known as the "Quartel." A special thank you is extended to David Hafernik for his many hours in the archives following the field work. Cathy Dodt assisted Kenneth Brown in running a transit traverse from Arneson Theater to the benchmark at the site.

The preliminary report of investigations is the product of many individuals from several different research facilities and institutions and has been written by five principal authors. Several individuals deserve special thanks for their help with the report preparation: Kenneth M. Brown, David Hafernik, Bruce E1 1 is, and Cathy Dodt for map and figure preparations; Gary L. Foreman and Elizabeth Craig for their expertise behind the camera and in the darkroom; Lynn Highley for her organizational and cataloguing skil1s which are essential to al1 artifact analyses; and Kelly Scott for her assistance in the preparation of this manuscript. Ernest Lundelius, Jr., Melissa Winans, Eileen Johnson, and Dale Winkler provided helpful discussions during analysis of the animal bone (Chapter 6); Dale Winkler also identified the bird remains.

Without the combined efforts of these many people, this preliminary report of investigations at La Vil1 ita Earthworks could never have been possible.

Joseph H. Labadie

Project Director 



\title{
CHAPTER 1 \\ PROJECT OVERVIEW
}

\author{
Joseph H. Labadie
}

\section{INTRODUCTION}

Archaeologists from the Center for Archaeological Research (CAR), The University of Texas at San Antonio (UTSA) recently completed excavations (February 16-March 1, 1985) in downtown San Antonio, located at the corner of South Alamo Street and East Nueva Street. On March 6, 1985, at ceremonies commemorating the 149.th anniversary of the battle of the Alamo, Dr. Thomas R. Hester, director of the Center of Archaeological Research at UTSA announced that the preliminary analyses of the artifacts discovered at the South Alamo Street and Nueva Street site could be directly 1 inked to the battle of the A 1 amo. Specifical1y, the site consisted of an L-shaped remnant of a trench dug as part of an earthworks for a military position used by General Santa Anna's Mexican soldiers during their siege of the Alamo in 1836. Shortly after the battle, the earthworks were partially filled, preserving some of the military objects that had been abandoned by Mexican soldiers. The upper deposits in the trench contained household refuse from La Villita, along with scattered military items, which date from the 1830 s to the $1850 \mathrm{~s}$.

The site is considered to be unique for reasons other than just the artifacts themselves, as this site is the first military post ever discovered that relates the Mexican side of the battle of the Alamo. The site is one of several known to have been used by Santa Anna, but it is the only one to have been found through archaeology.

This preliminary report of investigations of La Villita Earthworks (41 BX 677) has been conducted under the terms of Texas Antiquities Committee Permit No. 480. The report is not intended to be an all inclusive treatment of the project. Rather, it is designed to provide the reader with a timely summary of the excavations, historical research, and 7 aboratory analyses that have occurred to date. A final report, which will contain a complete study of all materials, is currently in preparation.

At this point in the project, artifact analyses have proceeded at different rates due principally to the sheer volume of materials to be studied. Each analysis though, has reached a point that allows for some detailed observations and general interpretations of what this site means to San Antonio's history.

At present, six special studies are in progress: military artifact analysis, ceramic analysis, faunal analysis, paper fragment analysis, $X-r a y$ analysis of metal artifacts, and historical and archival research. Additional special studies will be necessary to address the materials that were not included in the initial analyses. These studies will include prehistoric artifacts (1 ithics and ceramics), personal items (beads, jewelry, pipes), clothing items (buttons, buckles, and other types of fasteners), domestic items of a nonmilitary nature (spoons, knives, handles, pans), domestic construction items (nails, window glass, plaster), furniture items, (knobs, handles), flotation studies of soil matrix samples, and studies of artifacts that 
reflect past activities (toys, writing materials). The final report of investigations will provide a vast array of data by which all past, and future, archaeological interpretations of San Antonio during, and following, the battle of the Alamo, can be further compared.

\section{PHASE I INVESTIGATIONS (MONITORING PROGRAM)}

Prior to the commencement of bul1dozing activities and lot preparation at the Fairmount Hotel relocation site (New City Block [NCB] 155, Lot 6), the archaeological monitoring program was discussed at the site by representatives from the CAR-UTSA (Joe Labadie), Alamo Architects (Mike McGlone), and Guido Construction Company (Johnnie Sirianni). The archaeological monitoring was done under contract with Alamo Architects (dated February 4, 1985).

Two maps of the 1 ot had been prepared by the CAR-UTSA, one depicting 20thcentury construction and the other of 19 th-century construction; the maps were prepared from historical research provided by Alamo Architects. No historical research had been conducted by the CAR-UTSA prior to the Phase I investigations. The probability of hitting subsurface building foundations was discussed, noting specific structures on both maps. It was stated that if such features were encountered, they would need further investigation by the CAR monitor (archaeologist) to isolate the specific structure represented by the foundations or features.

It was stated by the CAR monitor that if any archaeological deposits were identified during bul1dozing activities, each would have to be further investigated to define the depth, areal extent, and temporal placement of each feature; all features would be mapped prior to continuing lot preparation. It was noted that a typical archaeological deposit may consist of wood charcoal and ash, broken pieces of ceramics and tablewares, animal bones, and rusty pieces of metal.

The approximate size and 1ocation of the Canterbury home (a mid-to-1ate 19thcentury residential structure known to have existed on Lot 6) was noted on the prepared maps. The distinct probability of finding some sort of 1 inear feature (east-west) along the rear lot or property 1 ine associated with this structure, was also discussed. For this reason, it was agreed by al1 parties that the bul1dozers would strip the soil down, rather than taking out large scoops of earth and destroying such a feature, if one stil1. existed. The differences in the location of East Nueva Street and South A1 amo Street prior to widening (early 20th century) were noted on both maps. Mike McGlone noted additional changes in the traffic flow patterns on South Alamo Street which were related to the Hemisfair Project during the $1960 \mathrm{~s}$.

The objective of the bulldozing was to excavate approximately two-thirds of Lot 6 to a depth of nearly 10 feet below present-day street 1 evel. Once accomplished, the new foundation for the Fairmount Hotel would be constructed and ready before the building made its much heralded trip from its original location. To accomplish this, two bulldozers, loading five dump trucks, began removing earth at the lot on February 16, 1985. 
The bulldozers began work on opposite sides of the lot (east and west) after a 1 imestone block wal1, which had enclosed the lot, was demolished. After the asphalt surface had been ripped up, fill was removed in about six-inch increments across the entire lot, and then piled in the center of the lot for loading into dump trucks. Earth removed from the site was taken to Saint Joseph's Elementary School to be used as fill (personal communication with Johnnie Sirianni).

At approximately three feet below the street level, a linear ashen feature was exposed by the bul1dozer operator on the eastern side (South Alamo Street) of Lot 6 . The bu 17 dozer operator was ordered to work el sewhere unti 1 the archaeologist from the CAR had time to investigate the deposit and map the approximate location, depth, and areal extent on a map al ready prepared for such an occasion. The ashen feature was orjented east-west and contained 1 arge quantities of ash, wood charcoal, unburned animal bones, and four different types of ceramic sherds. The probability of finding a household midden deposit associated with the Canterbury home in this approximate area had been previously discussed. The artifacts, however, indicated the ashen feature could be dated to about 1850; a majolica pottery sherd suggested an even earlier date. The feature was clearly not associated with the Canterbury home, and predated any known residential occupation on Lot 6 according to the historical research supp 1 ied by Alamo Architects. Bu11dozing activities on the eastern portion of Lot 6 were suspended for the remainder of the day. On February 17, an area rough 7 y $7 \mathrm{~m} \times 11 \mathrm{~m}$ was roped off, and an intensive shovel test program (Phase II investigations) began (Fig. 1,a).

\section{PHASE II INVESTIGATIONS (SHOVEL TEST PROGRAM)}

The shovel testing program intensively investigated the subsurface soil of an area roughty $77 \mathrm{~m}^{2}$. This area had been roped off to prevent any additional destruction of the deposits; bul1 dozing activites continued outside this area and eventual1y created a 77-m 2 island" which rose nearly $2 \mathrm{~m}$ above the final bul1dozed surface (Fig. 1,b). A total of 31 individual shovel test probes, employed in a grid pattern, was necessary to define the areal extent of the deposits. The location of test probes is presented in Figure 2.

The grid pattern technique provided the quickest and most comprehensive method of sampling by which to determine the depth, areal coverage, and temporal placement of the deposits. The ground surface at which this program began was approximately $1 \mathrm{~m}$ below the present-day street level; the ground surface sloped nearly $1 \mathrm{~m}$ from west to east across the $77-\mathrm{m}^{2}$ area.

A1 1 shovel tests were approximately $20 \mathrm{~cm}$ to $25 \mathrm{~cm}$ in diameter; their depths ranged from $20 \mathrm{~cm}$ to $87 \mathrm{~cm}$. On 1 y two types of soil were identified during this phase of testing: (1) beige caliche (10 YR 7.5/3, according to Munse 11 color charts), which contained no cultural materials; and (2) Houston B1ack clay (10 YR 4.5/1), which contained an incredible volume of cultural materials, and a11 appeared at the time to predate 1850. The contact between these two types of soil was sharp and well defined across the site. 

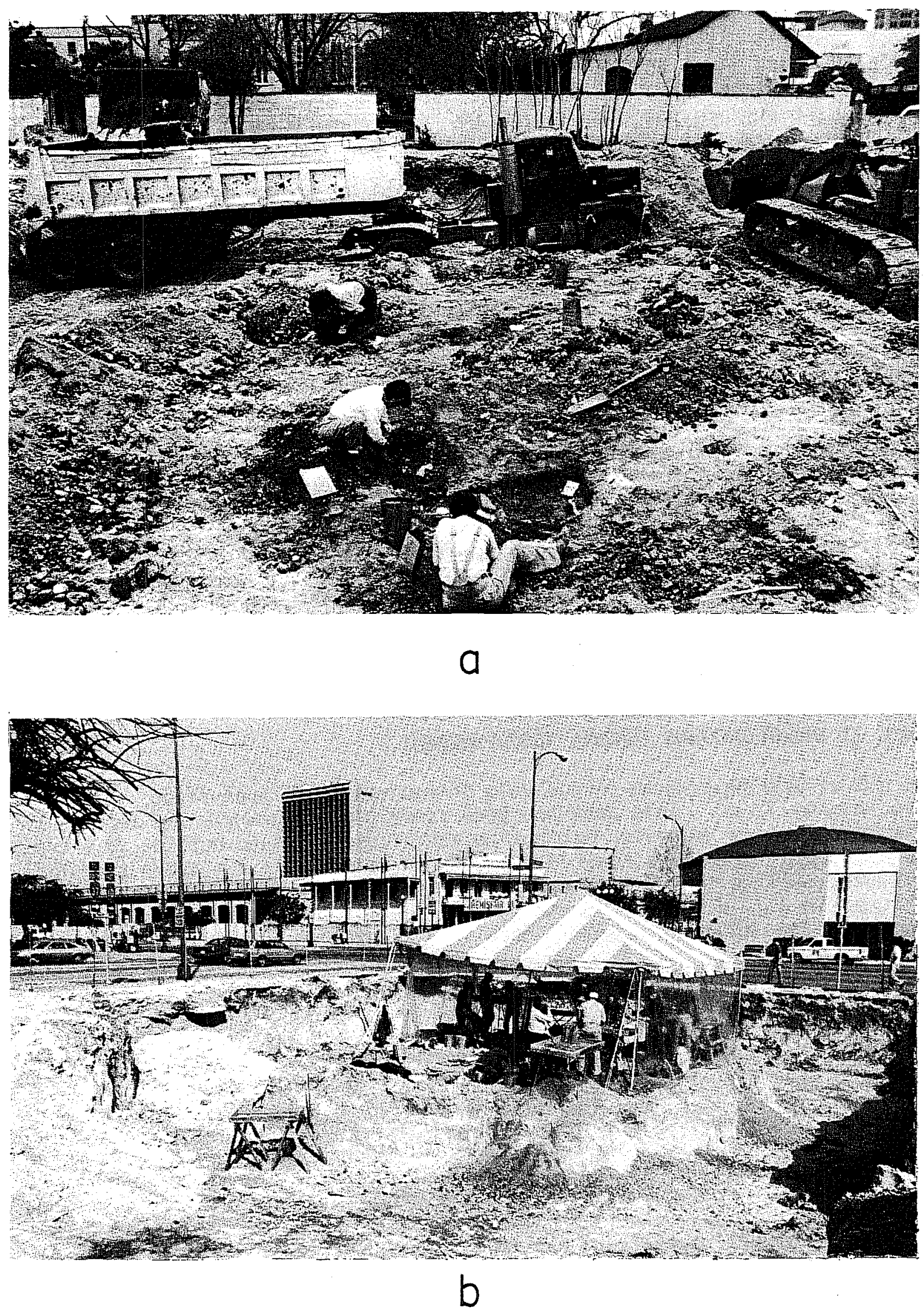

Figure 1. Archaeological Testing on NCB 155, Lot 6. a, testing and 1 ot preparation; $b$, the "island" created by bulldozing at the corner of East Nueva Street and South Alamo Street in downtown San Antonio, Texas. 


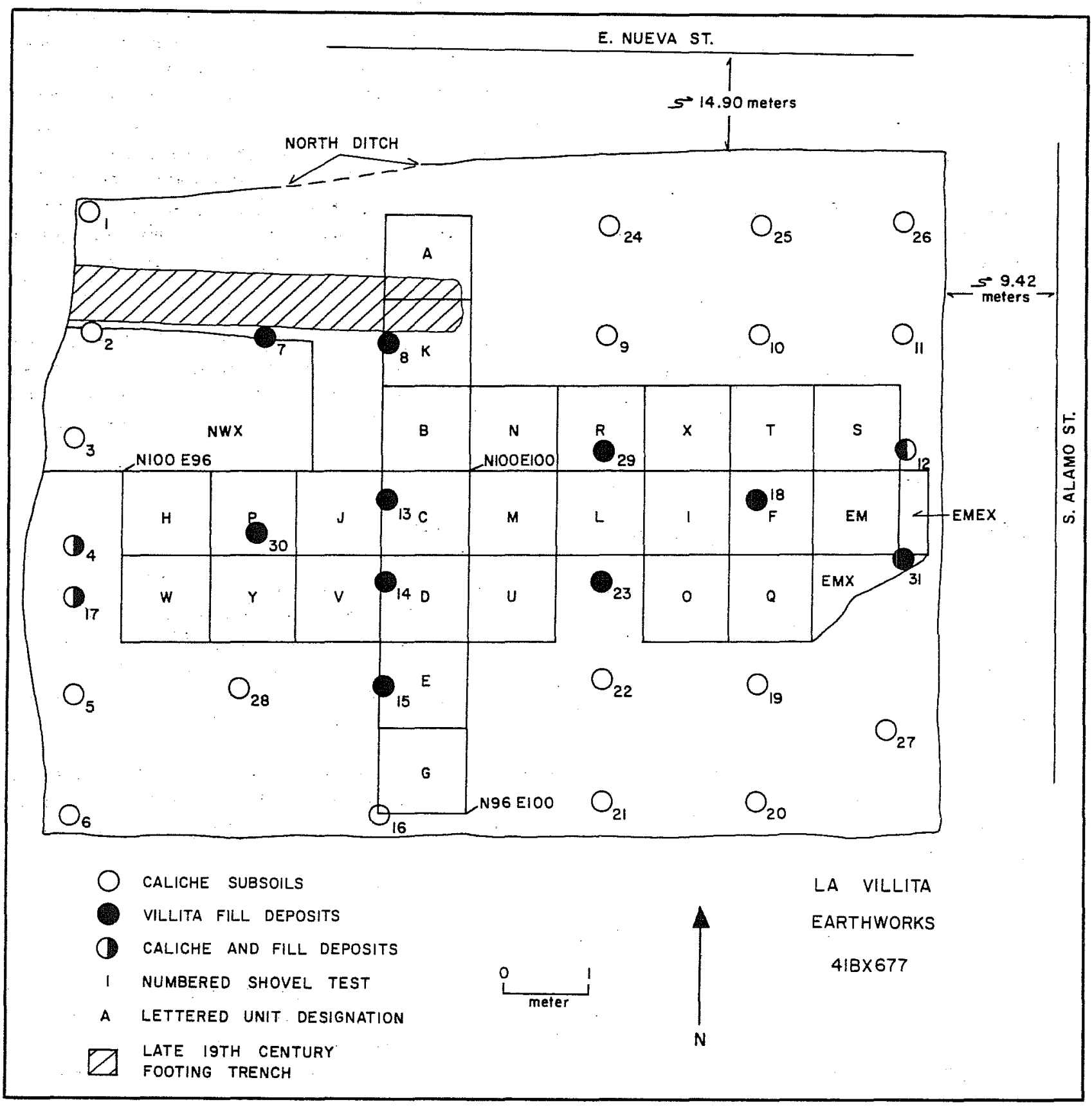

Figure 2. Location of the Phase II Shovel Tests and Hand-Excavated Units on the Northern Portion of NCB 155, Lot 6. 
The results of the Phase II shovel testing revealed that the areal extent of the deposits was confined within the $77-\mathrm{m}^{2}$ area that had been roped off previously. The east-west 1 imits had been defined fairly accurately (see Fig. 2, ST-4, ST-17, ST-12, ST-31). The north-south extent varied from $1 \mathrm{~m}$ (ST-23 to ST-29) to almost $4 \mathrm{~m}$ (ST-8 to ST-15). The depth of deposits ranged from $30 \mathrm{~cm}(S T-18)$ to more than $87 \mathrm{~cm}$ (ST-8). A 1 arge number of artifacts were recovered from the 31 separate shovel tests: ceramic sherds leight patterns of European-made transferwares, al1 pre-1850s; tin-g1azed majolica sherds; and several bone-tempered Goliad ware sherds), 1 arge animal bones (vertebrae, ribs, and teeth), and numerous small rusty iron fragments. Four musket bal1s (0.61 to 0.69 caliber) and a gunflint were surface collected at this time.

Once the depth and areal extent of deposits had been identified, the 77-m ${ }^{2}$ area was gridded in $1-m^{2}$ excavation units. An agreement had been reached with the developers, and the original contract was amended which allowed for additional testing of the midden deposits through controlled excavation of selected grid units.

\section{PHASE II INVESTIGATIONS (CONTROLLED EXCAVATION)}

Phase II investigations at the site were scheduled to 1 ast for five working days (February 20-26), utilizing a team of six archaeologists (contract between Alamo Architects and the CAR-UTSA, dated February 22, 1985). Due to heavy rains, and several extensions granted by the developers, Phase II operations actual1y 1 asted from February 20 to March 1 . A total of 63 workers spent over 1300 man-hours during this phase of operations alone.

The original plan was to excavate eight $1-\mathrm{m}^{2}$ units along two axes which would transect the main deposits north-south and east-west. With the huge number of volunteer excavators from local archaeological organizations (STAA and TAS), a total of 29 excavation units was eventualiy dug.

\section{FIELD RECORDING SYSTEM (Shirley Van der Veer)}

The archaeological testing and controlled stratigraphic excavation at La Vil1ita Earthworks followed standard archaeological procedures. Documentation of the field work included the use of unit-level recording forms completed by excavators; scaled profile, feature, and floor plan drawings; and photographic recording.

Photographic recording consisted of two formats, $35 \mathrm{~mm}$ and $1 / 2-$ inch color video tape. Project photograph logs were maintained for $35 \mathrm{~mm}$ field record shots in black-and-white print film (Pan-X and Plus-X) and color slide film (Kodachrome 25 and 64). A local Public Broadcasting Station in San Antonio (KLRN Channel 9) filmed about six hours of 1/2-inch color video tape which spanned six of the 10 days of field work. This $f i 1 \mathrm{~m}$ has been acquired from the station and will form the nucleus of a film documentary on this excavation. 
The initial establishment of the field recording system was made by the field director. A three-dimensional system was designed to provide a method for plotting the relative location of artifacts. Opening elevations for excavation units were calculated on an arbitrary $100.00 \mathrm{~m}$ vertical system by the use of transit and stadia rod. This arbitrary system was eventualiy then calculated relative to the city benchmark (651.05 feet mean sea level [MSL]) at the corner of East Nueva Street and South Al amo Street. The northeast corner of each excavation unit was established as a vertical datum for each excavated level by the use of string and line level.

The grid system employed at the site consisted of a main north-south base 1 ine oriented on magnetic north (Fig. 2). An east-west base 1 ine intersected the main base 1 ine at the main site datum (NI00 E100). This grid system consisted of $1-m^{2}$ excavation units. Units were assigned both grid and letter designations (e.g., grid N103 E100 at the northeast corner of Unit A). Each unit was excavated in $10 \mathrm{~cm}$ arbitrary levels and screened through 1/4-inch hardware cloth; screeners collected everything, including unmodified rocks.

Units were given letter designations of the grid system as they were opened by the field director (Units $R$ and $V$ were assigned but not excavated). When excavations were discontinued, units had been assigned through the letter $Y$, and an additional three units were given designations, indicating the extension of the east-west trench to the east beyond the grid: the EM area (Eastern Margin) originally extended the east-west trench only part of $1 \mathrm{~m}$ (see Fig. 2) and was subsequently excavated farther to the east; when the EM area became a $1-m$ unit, the extension beyond EM to the east (approximately $30 \mathrm{~cm} \times 100 \mathrm{~cm}$ ) was designated EMEX (Eastern Margin-Extra Extension) and was stopped when the edge of the block was only a few centimeters away. An additional irregular area approximately $30 \mathrm{~cm} \times 100 \mathrm{~cm}$ was excavated to extend the south side of the EM unit. This small area was designated EMX (Eastern Margin Extension). One other area, designated NWX (Northwest Extension), was outside the established grid but was troweled and examined for evidence of the trench.

Under normal conditions, the field director and excavators would be responsible for al1 documentation pertaining to their work. However, it was deemed essential that time be saved in any reasonable manner, and this responsibility was then placed with a knowledgeable volunteer crew member who, with assistance from the laboratory director during rush times, kept the basic map of the excavation area showing unit assignments, and assigned sacks and unit level record forms for each level excavated, giving each sack and its accompanying - paper work a "Bag Number." Identifying information (such as bag number, coordinates, unit letter, level, excavator, and remarks) was written on the central $1 \mathrm{og}$, and when each $10-\mathrm{cm}$ level was completed the bags were brought in, checked off the $1 \mathrm{og}$, and stored for transport to the laboratory. The excavator was responsible for the completion of a unit-level form where a 11 information pertaining to their work was recorded. When an excavator was assigned to a different unit, al 1 paper work was returned to the documentation station to be used by the next excavator of that unit. Initially, the field director assigned item numbers to artifacts of special interest. It soon became apparent that this was time-consuming and was eventual 1 y abandoned except in a few cases. Every effort was made by the documentation station to make note on the central $10 \mathrm{~g}$ of any unusual 
artifacts in any one bag, or any pertinent 1 aboratory processing information that might be useful. This procedure became almost impossible to maintain as artifacts were so prolific. However, it is one of the best ways to help find a particularly outstanding artifact when it is needed later.

Occasionally, artifacts needing special care were excavated. The 1aboratory director was on hand to designate the method of recording, preserving, and how to transport the item to the 1 aboratory. As artifacts were excavated that were considered too large or heavy to be included in the level bag, they were taken to the documentation station with identifying information, wrapped in aluminum foil or boxed and taken to the 1 aboratory in separate containers.

Screeners helped in supplying excavators, the field director, and other key personnel with vials, plastic sacks, aluminum foil, and other equipment, and in carrying messages or doing other errands, thus saving excavator's and field director's time.

On the final day of work (February 28), excavation continued until 1 ate evening. Portable 1 ights and a gasoline-powered generator were installed during the 1 ate afternoon and early evening, and work continued. Upon cessation of excavation (9:00 P.M.), those remaining were given buckets for designated areas, and they were instructed to remove the material in the area stil1 untouched, using trowel or pick and shovel as seemed appropriate, taking care not to damage any artifacts encountered, if at al 1 possible. These artifacts were then placed in the buckets and bagged and 1 abeled as "unprovenienced."

Work stopped around midnight. The next morning the remaining soil was removed by a bul1dozer; a portion (three dump trucks) was taken to the The University of Texas at San Antonio and placed near the archaeology 1 aboratory to be screened. In the ensuing days, several volunteers as well as staff members came to screen the material. Sacks for the artifacts were provided by the laboratory, marked as BD (backdirt), and processed in the same manner as provenienced artifacts. 


\section{CHAPTER 2 \\ HISTORICAL AND ARCHIVAL RESEARCH}

Joseph H. Labadie

\section{INTRODUCTION}

The artifact assemblage from La Vili ita Earthworks (41 BX 677) has been designated as a State Archeological Landmark. The site is located on New City Block (NCB) 155, Lot 6 (Fig. 3). In recent years, the 1 and ownership of the various 1 ots on NCB 155 has been the top ic of numerous reports and may well be the most intensively researched city block in downtown San Antonio other than the areas adjacent to the Alamo (Santos 1967; Fox, Valdez, and Bobbitt 1978; Ivey 1978; Katz 1978; F.ox 1983; Garay n.d.; Luckett n.d.; Schuetz n.d.). The issue of the location of a Spanish colonial structure known as the "Quartel" has stimulated much of this previous research; this issue will not be specifically addressed in this preliminary report.

The archival research for this project has centered on the sequence of 1 and ownership for the site area, beginning with the establishment of Mission San Antonio de Valero on May 1, 1718, and ending with the City of San Antonio's acquisition of the 1 and (1960s), which has subsequent 7 y been 7 eased to the Fairmount Hotel Company (1985). The archival and historical research has been designed to answer several specific questions:

1. When, and by whom, was the first residential structure built on the site?

2. Were there any structures on the lot (or immediate vicinity) in 1835 and 1836; if so, who owned the property at that time?

3. When, and by whom, was the first residential construction on the lot postdating 1836 ?

4. When, and by whom, was the structure built that is depicted in Augustus Koch's maps of 1873 and 1886 at the corner of East Nueva Street and South ATamo Street?

5. When, and by whom, was the gas station constructed on Lot 6 ? It is known to have existed in 1939 and is clearly visible in a photograph taken of the area now designated as La Vilitita Historical District in that year.

6. When were the buildings on Lot 6, as photographed in 1939, razed and the lot paved over for parking?

7. What building or structure is represented by the stone foundation and footing trench (Feature 4, see Chapter 3) identified during excavation?

The documentary research necessary to answer these questions is wel1 underway but is still far from complete. To date, hundreds of individual documents located at several different archival locations in San Antonio have been 


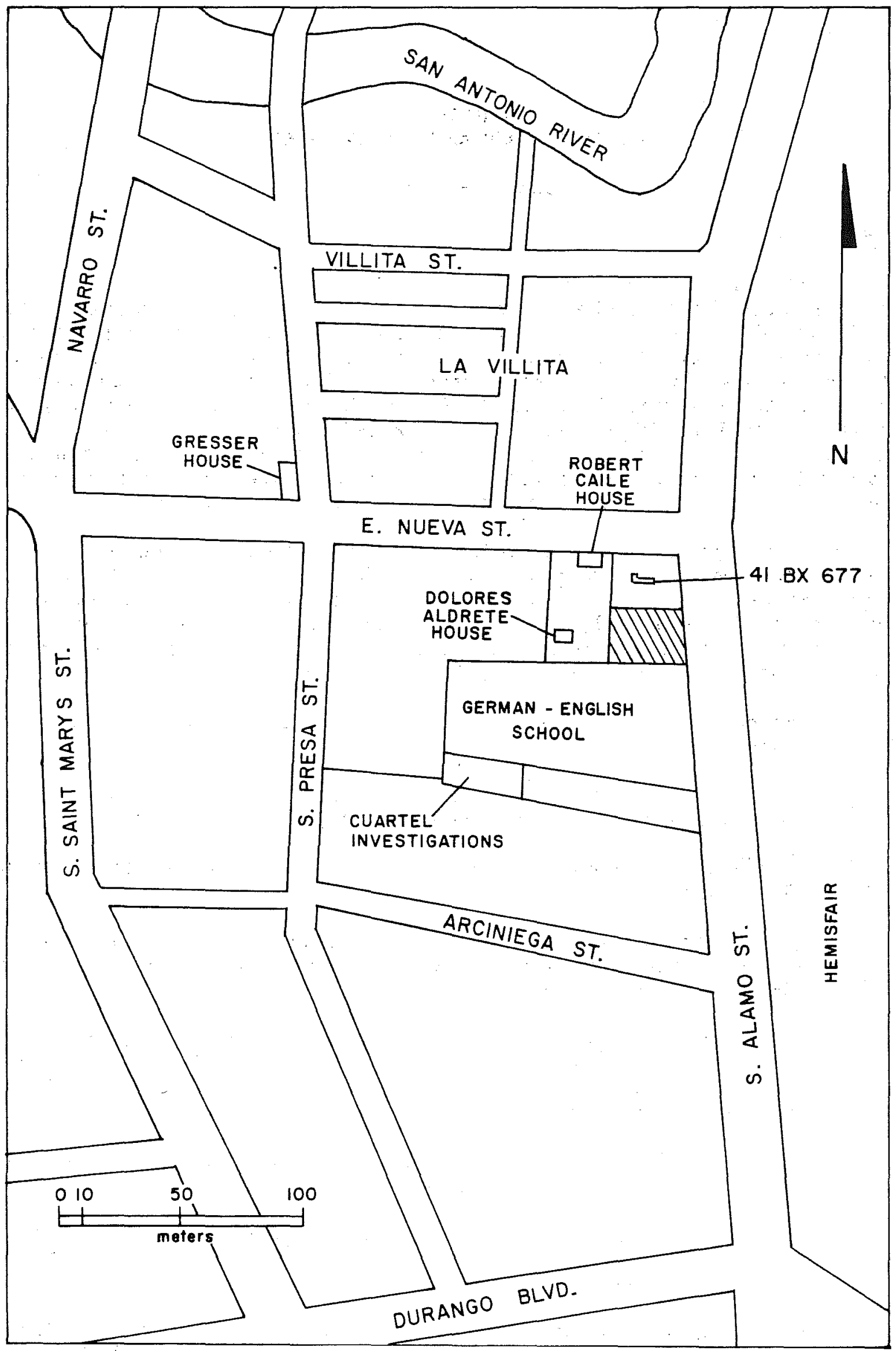

Figure 3. Location of La Villita Earthworks (4l BX 677) on the Northern Half of NCB 155, Lot 6. The southern half of Lot 6 (shaded) was tested during the Fairmount II Project (June 12-14, 1985; Labadie 1986). Adapted from Fox, Valdez, and Bobbitt (1978:Fig. 1). 
examined. The fol 1 owing documents located in the Bexar County Courthouse were consulted: Bexar County Deed Records (BCDR), 1720s to 1970s; Bexar County Land Grants (BCLG), 1720 s to 1847; Bexar County Probate Minutes (BCPM), 1820s to 1910; Bexar County birth, baptisma1, marriage, and death records. San Antonio city records examined are found in the following locations: City Right-of-Way Office, City Engineer's Office, San Antonio Historic Preservation Office (City Plat Index records), Minutes of City Council (SAMCC), and City and County Clerk's Records. District court records and Texas Supreme Court records and transcripts have also been consulted for information on specific court cases which involved 1 and ownership disputes for property located on NCB 155.

The presentation of the historical and archival data relating to NCB 155 , Lot 6, will generally follow the temporal subdivisions defined by the State Historical Resources Inventory (1966). These periods reflect the major historical changes which affected San Antonio and the State of Texas as a whole (Table 1).

TABLE 1. TEMPORAL SUBDIVISIONS AS DEFINED BY THE STATE HISTORICAL RESOURCES INVENTORY (1966)

EAS Exploration and Settlement (beginning 1528)

SMC Spanish Missions and Colonizing (1528-1800)

AEC Anglo-American and European Colonization of Texas (1800-1840)

TWI Texas War for Independence (1836)

ROT The Republic of Texas (1836-1846)

LSS Texas, The Lone Star State of the United States of America (18461861)

TCW Texas in the Civil War (1861-1865)

RP Reconstruction Period (1865-1874)

VT Victorian Texas (1874-1901)

FDT Texas in the First Decades of the 20th Century (1901-1930)

\section{PROBLEMS ASSOCIATED WITH ARCHIVAL RESEARCH IN SAN ANTONIO}

The documentary record relating to San Antonio's history spans nearly three centuries. As might be expected with a documentary continuum of this 1 ength, a varjety of problems confronts any archival researcher. Documents written in Castilian Spanish, inconsistently translated documents, or copies of originals, in both Spanish and English are commonplace. These 1 anguage and contextual problems are partially responsible for some of the disagreements which currently exist in the 7 iterature for this particular portion of downtown (e.g., location of the "Quarte1," the location of Miguel Arciniega's residence, the location of the Canterbury house, and the multiplicity of names for a single street such as East Nueva Street or South Alamo Street). 
Another problem, common to nearly a 11 documentary continua of this length, concerns the gaps or 1 ack of documents for a specific time period or geographic location within the city. San Antonio's early violent military history is partially responsible for these gaps and missing records. Some of the early Spanish Land Grant documents, under the charge of Baron de Bastrop, supposedly were destroyed with his residence around 1813 (Texas Supreme Court Records Vo1. 31:47, in Luckett n.d.). General Arrendondo reported ly damaged the Bexar Archives when he occupied the city in 1813, and may have taken some of the records with him to Laredo. Additional gaps and blank spaces in title transfers and acquisitions occurred when residents did not bother to file for grants or title, al though they occupied the 1 and for years (e.g., Dolores Aldrete deed, BCDR Vo1. LGS-44). During the Revolution of 1836, the Bexar Archives undoubtedly suffered casualities as well.

These problems, briefly discussed, are not insurmountable; rather, they create the environment within which any research must be conducted in $S a n$ Antonio. Historical research, therefore, requires a healthy skepticism of most of the early or transcribed records as inconsistencies between groups of records do exist. Several 1 ines of investigation are often required to resolve a particular issue or to confirm the reliability of any single document.

\section{SPANISH MISSIONS AND COLONIZING PERIOD (1528-1800)}

The 1 and ownership for the property on which La Vil1ita Earthworks was discovered can be traced back to the beginning of the settlement of what is now known as San Antonio. On May 1, 1718, Mission San Antonio de Valero was founded, named in honor of Saint Anthony of Padua and the Marquis de Valero, the Viceroy of New Spain (Fox, Bass, and Hester 1976:2). By 1727, the mission complex had for the third time been relocated, which is the presentday location. The population at the mission had increased to 70 families from three Indian nations, the Xarames (Aranamas), the Payayas, and the Yerebipiamos (Ervipiame; ibid.:3). Construction at the mission location at this time consisted of a convent, a granary, and sleeping quarters. The digging of the "Acequia Madre" (main irrigation ditch) had reached to within about one league of the mission.

In 1720, Mission San José was established just a few miles south, down river from Mission San Antonio de Valero. By 1731, three additional missions (Missions Espada, Concepción, and San Juan) were also in operation down river from Mission San Antonio de Valero (Corner 1890:37). The "Pajalache" or Concepción ditch (acequia) was also begun during this decade. The dam for the acequia was built across the river just west of present-day Presa Street (hence the name "Presa") and roughly followed Garden Street (now known as St. Mary's Street) in a direct 1 ine to Mission Concepcion (Corner 1890:43). This chain of five missions along the San Antonio River was connected by the "Cal le que va para 1 as Misiones Abajo" (BCDR Vo1. SP-2:92), which began at Mission San Antonio de Valero and continued southward to the lower missions. This Royal Highway, denoted by "Cal1e" has been referred to by a variety of names during the past 250 years (Calle Real de Alamo [BCDR Vo1. A-2:303], La Calle principal que va para 1 as misiones [BCDR Vol. El:171], Street of the 
A] amo [BCDR Vol. F2:422], Mission Street [BCDR Vo1. A2:221-222]). Today, the street is known as Alamo Street.

By the mid 18th century, the general site area was referred to as the "Labor de Abajo" (1ower 1abor); the upper 1 abor, "Labor de Arriba," was the area near the acequia northwest of the mission (Fig. 4). The lower 1 abor area, delimited by the Concepcion Acequia on the west, the Acequia Madre on the east, the Alameda (Commerce Street) on the north, and the intersection of these two acequias on the south, was used for cultivation and pasturage during most of the 18th century. It has rich alluvium from overbank flooding of the San Antonio River and would have had an abundant water supply from the two nearby acequias.

A11 records from the period indicate that the lower 1 abor was unpopulated, although squatters or residents without legal title to the 1 and could well have occupied some portions of this area. The constant threat of Indian depredations 1 imited the populated sections of the town to two separate areas: (1) the mission compound and adjacent areas on the east side of the San Antonio River; and (2) the area of the Presidio de Bexar on the west side of the river, including "La Plaża de 1 as Yslas," which was established after 1731 for the Canary Islanders (Fig. 4).

Sometime between 1783 and 1785, Mission San Antonio de Valero ceased to be a mission (Corner 1890:76), although the Viceroy's official suppression order did not occur until January 9, 1793. In 1788, census figures show a resident population of 44 Indians, reduced from 144 Indians in 1783 (Habig 1939:65). Following the Viceroy's decree of 1793, the lower mission farmlands (Labor de Abajo) were surveyed and subdivided into suertes (ibid.:66); not al1 suertes were of equal size. The area of our excavation is part of one of these suertes of 1 and.

On Apri1 11, 1793, Father Jose Francisco Lozano, acting on Governor Manuel Munoz's order of February 23, 1793, began the distribution of property and goods which belonged to Mission San Antonio de Valero to the Indians and residents of the mission, which included some 40 refugees from the abandoned Presidio of Adaes in east Texas. Some of the cattle, horses, corn, beans, and salt were assigned to the new Mission of Refugio (Habig 1939:66). Also on that day (February 23), Father Lozano:

- . distributed among 39 mission Indians a supply of corn which was to take care of their needs until the new crop was harvested. This was given to ten heads of families, one of them a widow, and to four other unmarried adults. Each of the 14 persons also received a pair of oxen, a plow, a harrow, a hoe, and a cow with a calf. Additional corn and other supplies including 10 horses, were given to them two days 1 ater. The other 18 mission Indians, who were Lipan Apaches, were to be moved to Mission San Jose. . . they were also permitted to stay (Habig 1939:66).

Pedro Huizar had surveyed and subdivided the lower mission farm (Labor de Abajo) with his assistant Vicente Amador. On Apri1 12, 1793, both received a suerte of 1 and for their work (ibid.:67). The 1 ands divided among the 40 Adaiseños, the mission Indians, and 14 families of San Antonio were located 


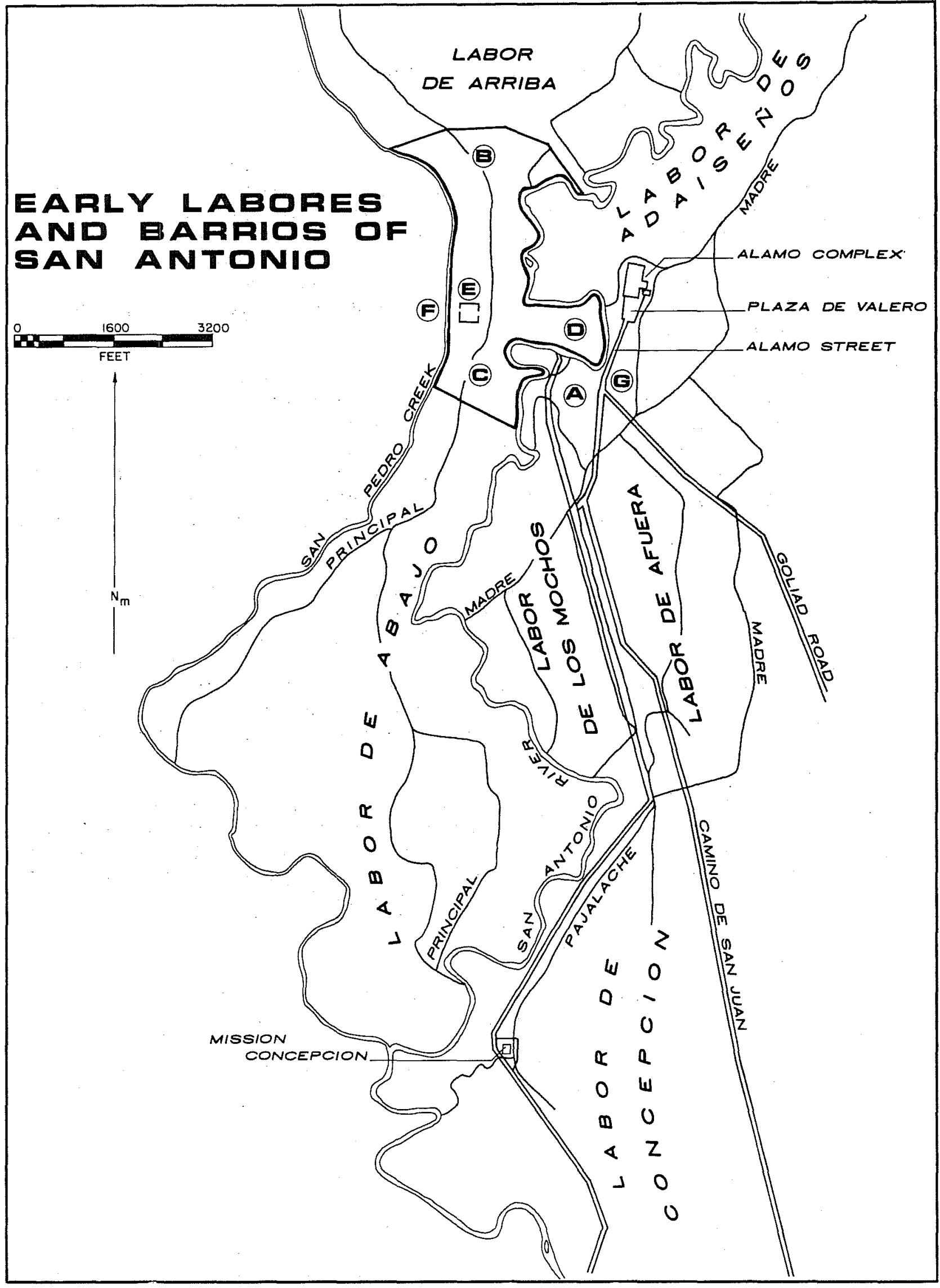

Figure 4. Early Labores and Barrios of San Antonio During the Early 19th Century. A, Villlita; B, Barrio Del Norte; C, Barrio Del Sur; D, El Potrero; E, Plaza De Armas; F, Laredito; G, Barrio Del Alamo. 
on the east side of the San Antonio River and north of the mission. Governor Munoz also gave:

- . to each of the 14 heads of families and unmarried adults a tract of 1 and 1 arge enough for the planting of one and three-fifths bushels of seed (Habig 1939:37).

Who actually received title to the property on which La Villita Earthworks is situated, following the initial 1 and distributions in 1793, is unknown. It was not until 1811 that the first recorded deed which mentions the site area appears in the Bexar County Deed Records (BCDR Vo1. LGS-40).

\section{ANGLO-AMERICAN AND EUROPEAN COLONIZATION OF TEXAS PERIOD (1800-1840)}

With the secularization of Mission San Antonio de Valero in 1793, the role of the Alamo as a mission ended. The mission records were transferred to the Villa de San Fernando Church Archives, the farmlands distributed among mission residents, and the mission building complex and corrales were officially abandoned. The buildings were stripped of usable items such as doors and locks (Chabot 1937:14), and the complex went unoccupied after 1800.

On December 29, 1802, a Spanish cavalry unit, the Compañia Volante of San Carlos de Parras de Alamo from Chihuahua, was permanently reassigned to San Antonio and occupied the abandoned mission complex (Fox, Bass, and Hester 1976:6-7). By 1810, repairs and improvements, which included the addition of a fully equipped 30-bed hospital, had made the old mission complex a habitable and defensible military outpost for Spain once again. Evidentiy, the old mission became known as the "Alamo" during this time.

The soldiers who were assigned to the Compañia probably 1 ived in and around the Alamo complex. Records from the time indicate that company members and their families were recorded as a distinct group within the 1 arger populace of San Antonio in each census of the Compañia (Bexar County Archives, microfilm roll 35:561, microfilm roll 43:656, cited in Ivey 1978:1). A smal1 populated area southwest of the Alamo became known as the "barrio del Al amo" and undoubtedly housed some of the soldiers and families from the Compañia.

The area south of the "Potrero," fronting on South Alamo Street, bounded by East Nueva Street on the south, and the San Antonio River on the west, may a 1 so have been occupied by these soldiers and families. By 1807, the area south of Commerce Street, along the west side of South Alamo Street, was being referred to as "La Villita" (see Fig. 4). Deed records for the next few years (1807-1810) witnessed a flurry of activity in lot sales and title transfers around the Alamo and La Villita. After 1 ate 1810, there was a general hiatus in the sale and transfer of property everywhere fol lowing Hidalgo's Revolution in Mexico City. Beginning in 1ate 1813-ear1y 1814, and following three years of violence, property confiscations (by Casas in 1811 and Arrendondo in 1813), and several political/military administrations (Saucedo in 1810, Casas in 1811, Zambrano in 1812, Gutierrez-Magee in 1812, and Arrendondo in 1813), San Antonio returned to a period of moderate tranquility. 
The first recorded deed record which mentions an owner (Clemente Delgado) for the site area is dated November 14, 1811 (BCDR Vo1. LGS-40). Gregorio Arciniega petitioned the Judge of Valero (Vicente Gortari) for a tract of 7 and south of La Villita which was:

- . situated on the street which leads to the lower missions [South Alamo St.]; this 1 and is bounded on the east by said street; on the south by 1 and of Cayento Domingues... and on the north by Clemente Delgado (BCDR Vo1. LGS-40:1)

Arciniega did not receive the tract of 7 and he had originally requested, and, on November 25,1811, was granted a solar of 1 and in the same general area measuring "30 varas in frontage and 60 varas in depth"; he had requested a tract measuring 140 varas by 200 varas frontage on South A1 amo Street (ibid.). The solar of 1 and which he received from the Judge of Valero was:

- . bounded on the north by the solar of Clemente Delgado with a street between [Arciniega Street]; on the west by pub 1 ic 1 and; on the south by pub 1 ic 1 and, and on the east by the road leading to the missions [South AT amo Street] (BCDR Vo1. LGS-40:4).

The legal description for the solar of 1 and granted to Gregorio Arciniega is rather precise when compared to other deeds recorded during the early 1800 s. Arciniega's solar of 1 and has been reported previously (Katz 1978:12) as being 1 ocated on the eastern portion of NCB 155, "probably Lot 6 on the northeast corner" (East Nueva Street and South A1 amo Street). Katz p 1 aces the Delgado tract on NCB 114 (the two blocks [NCB 155 and NCB 114] are divided by East Nueva Street), but provides no reference for this evaluation. As additional proof that Arciniega owned the eastern portion of NCB 155, Katz cites a deed transfer from Jose Antonio Delgado to John W. Smith (n.d.), dated May 14, 1839. This deed (Smith n.d.) refers to a parcel of 1 and in La Villita "being 20 varas by 100 varas, bounded by Nueva Street, South Alamo Street, Arciniega Street, and the property of Marfa Josefa Delgado" (Katz 1978:12). The deed (Delgado to Smith) refers to that property which is designated as NCB 155, Lot 6; the Miguel Arciniega deed (BCDR V01. LGS-40) does not refer to the same lot; it refers to the northeastern portion of NCB 901 which is the first block south of NCB 155 (Fig. 5). If the Delgado tract was located on NCB 114, as previously reported, how could Clemente give his son, Jose Antonio Delgado, land located on a different block--as evidenced by the description in the Delgado to Smith deed of 1839 (BCDR Vol. $A-2: 221-222)$ ?

Additional evidence that the Miguel Arciniega grant of 1811 was located on NCB 901, and not on NCB 155, is contained in the Delgado to Smith deed of 1839 (BCDR Vol. A-2:221-222). The description of the property reads:

- - being 20 varas front by 100 deep commencing on Mission Street [South A1 amo Street]... and from the Al amo to the Missions at the corner of and on the street that runs East and West and in front of Vicinte Miche $1 \mathrm{i}$ to, and dwe $11 \mathrm{ing}$ [South Presa and East Nueva Streets] thence south along sajd street. . . 100 varas to the street on the North and in front of Miguel Arciniega's [South Alamo Street and Arciniega Street], thence with said street in 
front of Arciniega's residence and immediately north of same in a west direction 20 varas to the Southeast corner of a lot belonging to Maria Josepha Delgado 100 varas to the street running east and west in front of Vicinte Micheli's making 2000 square varas.

The legal description for the 1 and acquired by John $W$. Smith is precise--on NCB 155; the 1ot was 20 varas deep by 100 varas in 1ength which fronted on South Alamo Street. This deed clearly places the Vicinte Micheli house (in 1839) on the northwest corner of NCB 155 (probab7y Lots 16 and 17) where the Saint John's Lutheran, Church now stands. The location for the Migue? Arciniega residence is also precise, and was located (in 1839) on the northeast corner of NCB 901 (Fig. 5).

\section{THE REPUBLIC OF TEXAS PERIOD (1836-1846)}

John W. Smith legally acquired NCB 155, Lot 6, from Jose Antonio Delgado in 1839. Jose Delgado had acquired the 1 and, by inheritance, fol 1 owing his father's death in 1834. His father, at the time of his death in 1834, had been residing in a stone house on two sitios of 1 and which he acquired in 1829 (Chabot 1937:174). The lot is described as:

- . fronting 17.5 varas north on the south side of the 'plaza principa]' [A1 amo Plaza], going back 130 varas to the street called 'of the lower 1 abor'. The eastern boundary of this property was the house of Gertrudis Salinas; the western, a jacal of Doña Gertrudis Salinas (Chabot 1937:174).

There appears to be some question as to which of Clemente Delgado's children (he had at least three, possibly four) received legal title to the property which John W. Smith purchased for $\$ 150$ cash in 1839. In 1832, Clemente Delgado made a "donation" of a parcel of 1 and, 20 varas by 100 varas (BCDR V01. C-1:97-99) to one of his children. The property description is nearly identical to the Smith deed of 1839--sold to him by Jose Antonio Delgado. In the Smith deed, Jose Antonio claimed ownership by inheritance. As to which one of Clemente Delgado's children "legally" owned the lot is unclear. The fact that John W. Smith purchased a 1ot, which had at one time belonged to Clemente Delgado before his death in 1834, seems apparent.

In 1839, John W. Smith appears to have had lega 1 title to Lot 6 . It cannot be determined if any type of structure stood on the 1 ot in 1835 and 1836. Normally, deed records will note if a structure exists on a lot at the time of the deed transaction. In other cases, the paid purchase price may imply that structure(s) existed; a low purchase price implying an unimproved lot. Clemente Delgado gave this lot as a "donation" to his daughter in 1834; there was no purchase price, and the deed does not specifically mention any structure. No archaeological evidence was found during excavation which could suggest a pre-1850 structure. Further archival research is necessary to determine if a residential structure existed on the lot during the time of the second $A l$ amo battle. It still seems plausible that someone was in fact making Lot 6 their residence; Dolores Aldrete had been 1 iving in the "palisado" home on Lot 7 since 1818. The house which once belonged to Dolores Aldrete is still standing in 1986. 


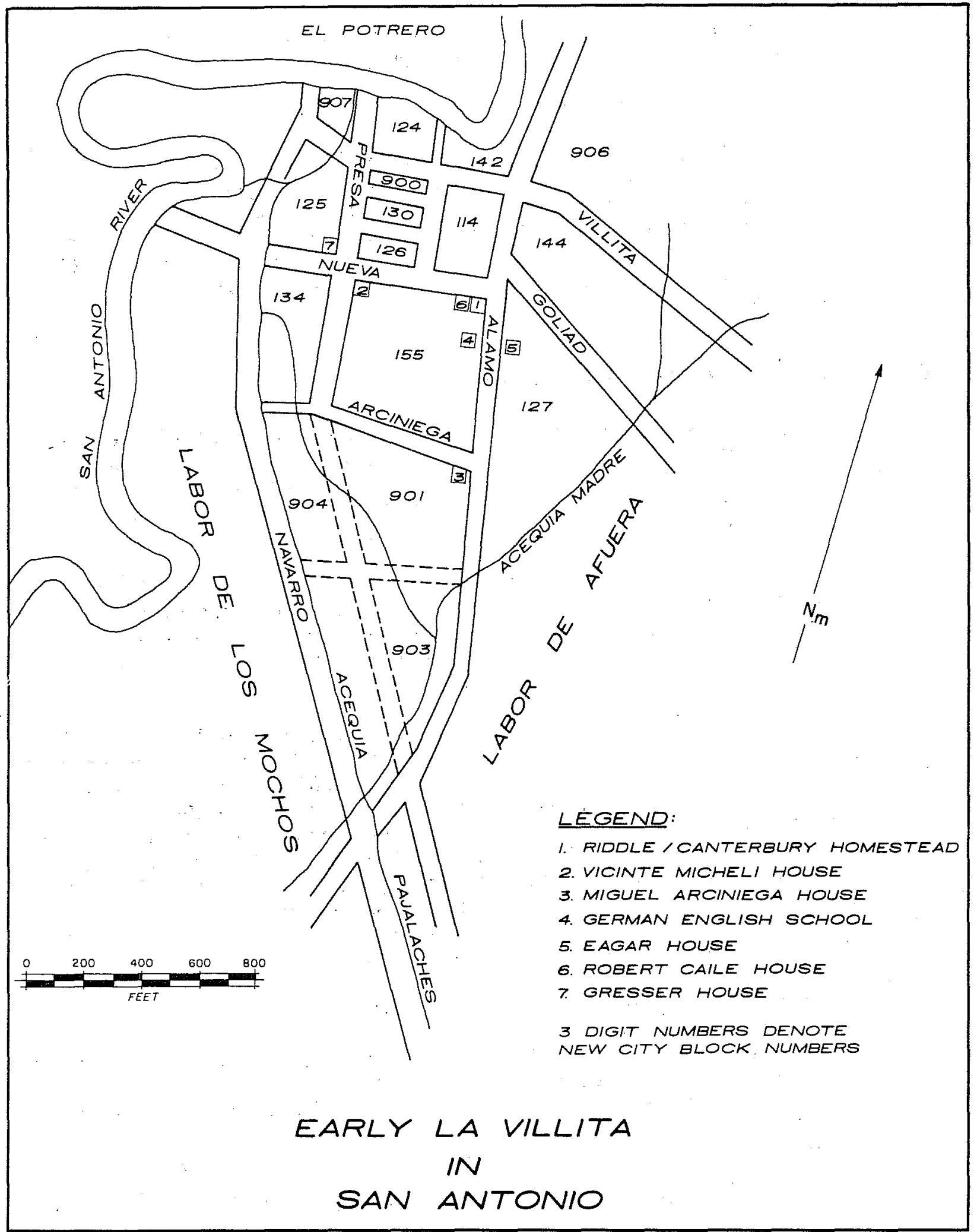

Figure 5. New City Block Numbers in the Vicinity of La Villita Historical District in Downtown San Antonio, Texas. 


\section{TEXAS IN THE LONE STAR STATE PERIOD (1846-1861)}

John Smith died in August 1848, and his will named his wife, Maria de Jesus de Lee, as executor of his estate (BCPM Vol. AB:63). Apparent1y, Smith's widow failed to meet taxes due on the inherited estate, and, by 1852 , the property was sold at public auction for back taxes. On March 4, 1852, Joseph H. Beck purchased Lot 6 which had formal 1 y been in the estate of John $W$. Smith (BCDR Vol. K-2:94). Beck apparently purchased this lot as an investment as he sold it to Durante Noble the following year (BCDR Vol. K$2: 547)$.

By 1858, John Riddle had acquired Lot 6 and transferred ownership to E1 izabeth Menefee Ridd1e, his sister-in-1aw (BCDR Vol.P-2:550). Records were not found to indicate a Durante Noble to John Riddle deed transaction or if the property had been owned by some third person between 1853 and 1858 . The Riddle-to-Riddle 1858 deed record provides no clues as to whether or not the lot included a homestead or structures of any kind.

\section{VICTORIAN TEXAS PERIOD (1874-1901)}

Lot 6, owned by E. M. (Riddle) Canterbury, was deeded to her son, John Warren Canterbury by 1880. In 1880, John W. Canterbury sold Lot 6 , with the Canterbury-Riddle homestead, to another family member, John W. Riddle (BCDR V01. 16:271). The homestead referred to in this 1880 deed record is probabiy the same one depicted in Augustus Koch's 1886 map of San Antonio (Fig. 6).

By 1896, E. M. Canterbury had again acquired legal title to Lot 6 , as she deeded the Canterbury-Riddle homestead and 1 ot "located at the northeast corner of Nueva and A1 amo Streets" (BCDR V01. 175:258) to her daughter Sara A. Eager. Exact1y how E. M. Canterbury reacquired the lot after she had deeded it in 1880 (BCDR Vol. 16:271) is stil1 unclear.

In 1927, South A1 amo Street and East Nueva Street were widened by the city. East Nueva Street was widened from 34 feet to 60 feet. The project p 1 an map on file in the City Right-of-Way Office (Vol. 957:398) clearly indicates the relationship of the old and new street right-of-way which has been superimposed on an updated 1904 Sanborn insurance map (Sanborn Map and Publishing Company, Ltd. 1904). The property that was needed to widen the street was purchased from owners on the south side of Nueva Street. Nearly every building on NCB 155 which fronted on Nueva Street was directly impacted by the new right-of-way. On Lot 6, the city acquired about 24 to 26 feet of property; this new property 1 ine ran right through the Canterbury-Riddle homestead. Structures on Lot $7,8,9,10,11$, and 12 were also within the new right-of-way and were probably torn down or radically modified.

Since the destruction of the Canterbury-Riddle homestead in 1927, Lot 6 has been the scene of strictly business and retail activities. By 1929, the Casseb brothers owned and operated a gas station on the northern half of Lot 6 (San Antonio City Directory 1928-1929). During the CAR excavations, three concrete pilings attributable to this gas station were recorded (Features 5, 6, and 7 discussed in Chapter 3 ). Two of the pi 7 ings intruded upon the deposits within the fortification ditch. The workers who dug the 


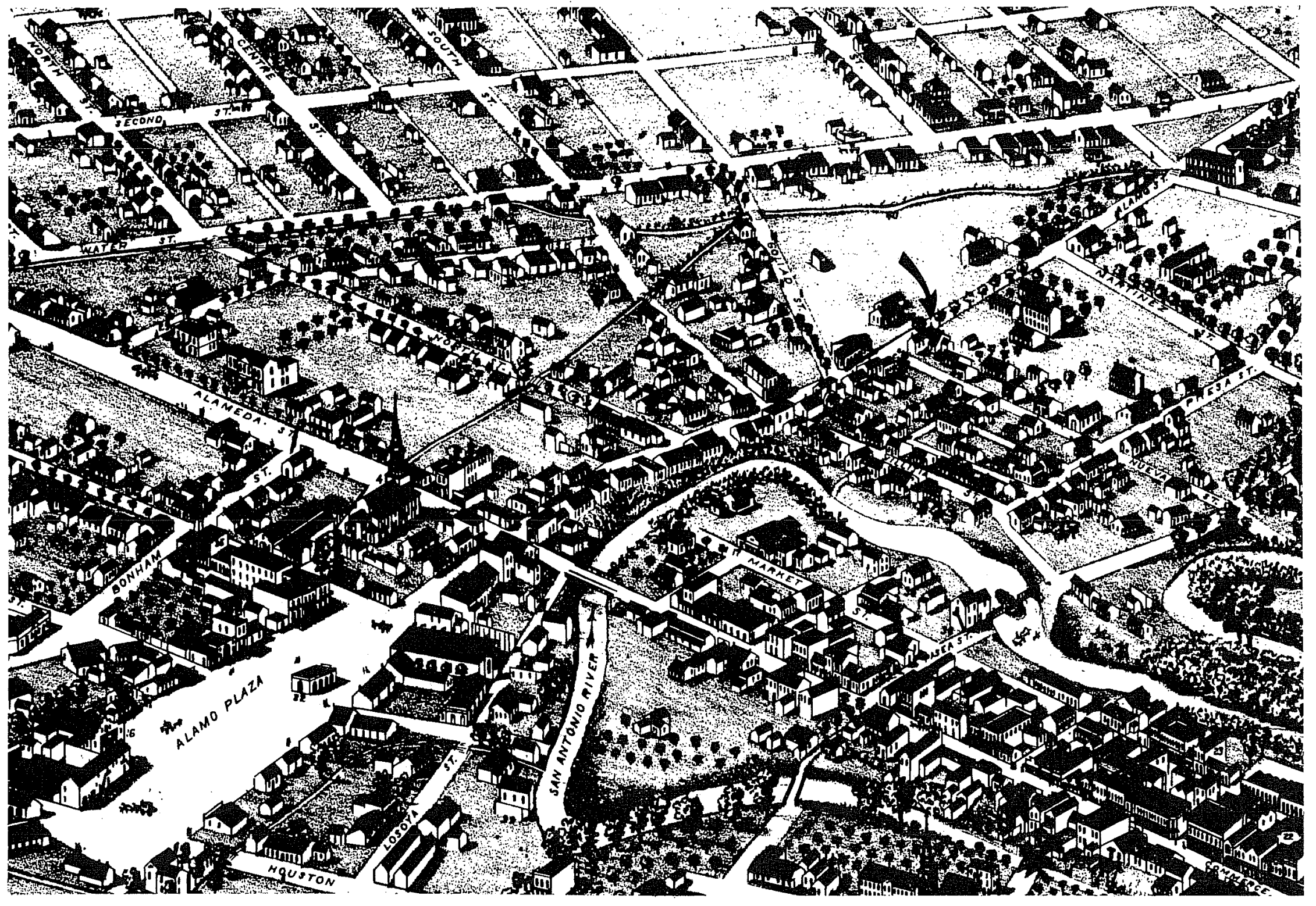

Figure 6. A Portion of Koch's 1886 Bird's Eye View Map of San Antonio Which Depicts a Structure at the Corner of East Nueva and South $A 1$ amo Streets. The structure the arrow is indicating may be the Canterbury-Riddle homestead. 
footings for these pilings undoubtedly found some of the same types of artifacts as those recovered by the CAR investigations.

It is interesting to note a very similar situation which focurred on $L$ ot 6 during the 1880s. The San Antonio Daily Express (Jahuary 28, 1882:4) reported that workers, while stablizing a sinking building foundation, had unearthed human bones and old trash during the course of their work at the Canterbury-Riddle homestead. The CAR excavations recorded a cut 7 imestone block building foundation and footing trench (Feature 4 discussed in Chapter 3) which also had intruded upon the fortification ditch. Several artifacts attributab 1 e to the 1 ate 19 th century (e.g., Owen's manufactured screw top $j$ ar) were found in the fill of Feature 4 and strongly suggest that this feature represents a portion of the stabilized foumdation for the Canterbury-Riddle homestead.

A 7 so about 1929, a two-story brick commercial structure was built on the southern half of Lot 6 (Labadie 1986:5, 6). This building apparently housed a bowling alley on the ground floor and a small retail business on the second floor (personal communication with Harvey Smith, Jr., who attended the German-English School on the adjacent lot during the 1930s). Both of these structures are clearly visible in an aerial photograph taken of La Villita Historical District that appeared in a book about the district pub 7 ished by then Mayor Maury Maverick (Fig. 7). These commercial structures housed several different businesses from 1929 to the early 1960 s (Tab1e 2). It appears that both buildings were razed shortly after the lot was acquired by the City of San Antonio in 1964. The lot was paved over and used by the city in connection with Hemisfair in 1968. By the early 1980s, this parking lot was being used for customers at the Four Seasons Hotel. By February 16, 1985. Lot 6 had been leased to the Fairmount Hote 1 Company as the relocation site for the historic Fairmount Hotel.

\section{SUMMARY AND CONCLUSIONS}

Table 2 provides a compilation of known 1 and ownership and occupants for NCB 155, Lot 6. The historical research for La Villita Earthworks is still in a preliminary stage of investigation. Sufficient archival research has been completed to address the seven research questions presented in the Introduction to Chapter 2, although there are several nagging issues which are still to be resolved.

1. The designation of the 1 ot as NCB (New City B 1ock) 155, Lot 6, did not occur until 1848 ( $G$ iraud 1848). It appears that $\mathrm{Clemente} \mathrm{Delgado}$ was the first "legal" owner of the eastern portion of NCB 155 following the secularization of Mission San Antonio de Valero in 1793. It is not known if Clemente Delgado or his children ever constructed a residence on the $10 t$ during their tenure of 1 and ownership (1811-1839).

2. It is not known if any structures were standing on Lot 6 during 1835 and 1836. The deed records provide no indication one way or the other; no archaeological evidence was found to indicate a structure during this time. 


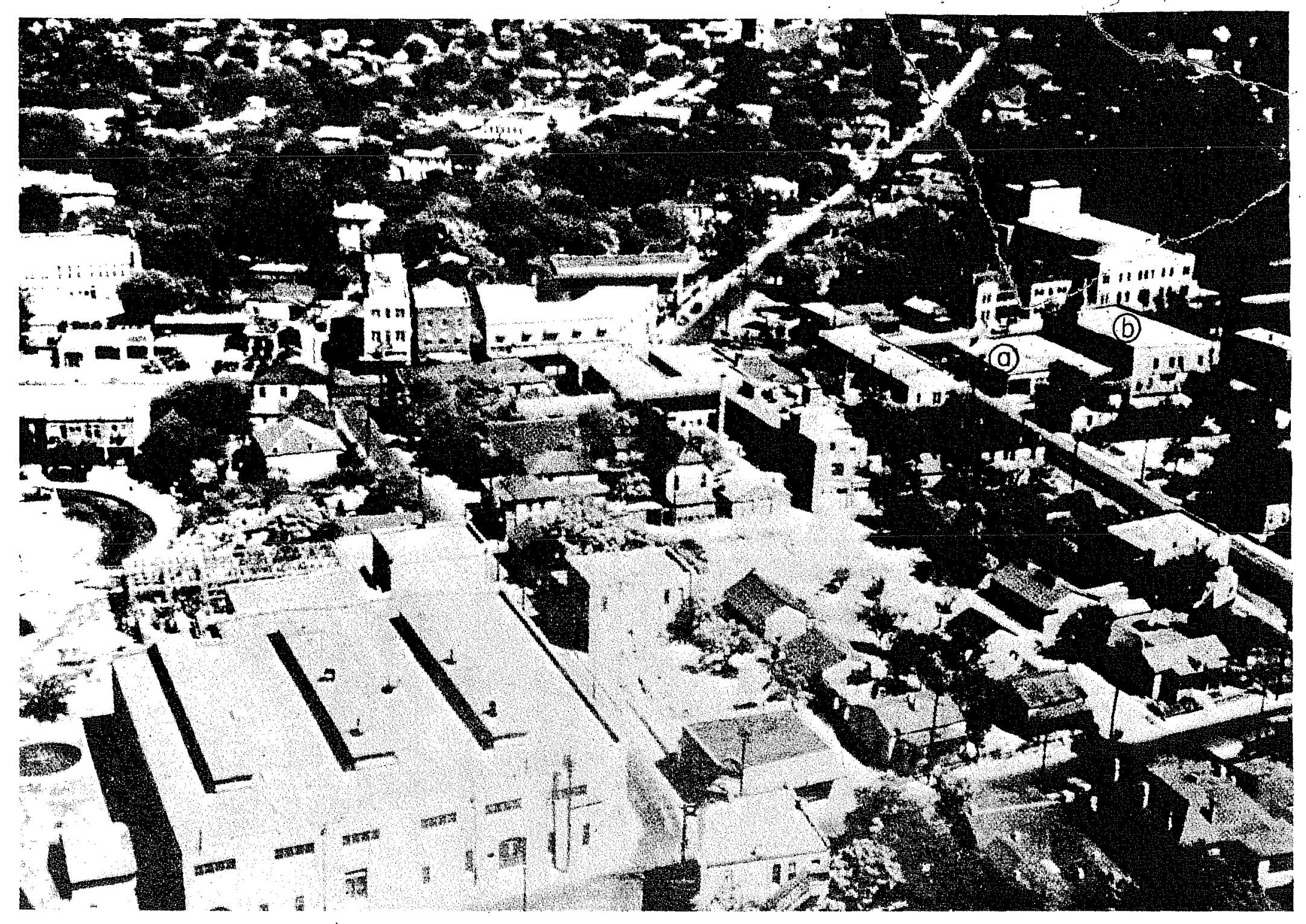

Figure 7. Aerial View of La Villita Historical District in 1939. (a) the Casseb Brothers Service Station at the corner of East Nueva Street, (b) two-story brick commercial structure fronting on South Al amo Street. Taken from Maverick (1939:21). 
TABLE 2. COMPILATION OF KNOWN DEED RECORDS AND BUSINESSES LOCATED ON NCB 155, LOT 6

\begin{tabular}{|c|c|c|c|}
\hline Year & Grantor & Grantee & Reference \\
\hline 1832 & Clemente Delgado & María Josefa Delgado & BCDR Vol. C-1:97-99 \\
\hline 1839 & Jose Antonio Delgado & John W. Smith. & BCDR Vol. A-2:221 \\
\hline 1848 & John W. Smith (decd) & Marla de Jesus de Lee (widow) & Inheritance \\
\hline 1853 & Joseph H. Beck & Durante Noble & BCDR Vol. K-2:547 \\
\hline $18 ? ?$ & $?$ & John Riddle & $?$ \\
\hline 1858 & John Riddle & ETizabeth M. Canterbury & BCDR Vol. P-2:550 \\
\hline $18 ? ?$ & Elizabeth M. Canterbury & John W. and Mary L. Canterbury & $?$ \\
\hline 1880 & John W. and Mary L. Canterbury & James Riddle & BCDR Vol. 16:271 \\
\hline 1934 & John A. Power opens a gas station & & Appler 1933-1934 \\
\hline $1951-1957$ & Lot $\sigma$ is vacant at this time & & \\
\hline $1958-1962$ & $\begin{array}{l}\text { Frank A. Schroeder App } 7 \text { iance } \\
\text { Company }\end{array}$ & & $\begin{array}{l}\text { San Antonio City } \\
\text { Directory 1957-1964 }\end{array}$ \\
\hline $1963-1964$ & Lot 6 is vacant at this time & & \\
\hline 1964 & $\begin{array}{l}\text { Land is acquired by the City of } \\
\text { San Antonio }\end{array}$ & & \\
\hline 1985 & $\begin{array}{l}\text { Lot } 5 \text { and } 6 \text { are leased to the } \\
\text { Fairmount Hotel Company }\end{array}$ & & \\
\hline
\end{tabular}


3. and 4. The first structure, postdating 1836, constructed on this 1 ot appears to have been the Canterbury-Riddle homestead. It.would have been built after 1858, and may very well be the structure depicted in Augustus Koch's maps of 1873 and 1886. This structure stood at the corner of East Nueva Street and South A 1 amo Street until at 1east 1927, and was probably torn down due to the widening of East Nueva Street that same year.

5. and 6. The gas station pictured (Fig. 7) in 1939, as existing on the northern half of Lot 6 , was constructed after the 1927 widening of East Nueva Street. A two-story brick commercial structure was built on the southern hal 1 of Lot 6 at about the same time (Fig. 7). Both structures stood until the early 1960s when the property was acquired by the City of San Antonio. Both structures were razed shortly thereafter; the 1 ot was paved over for parking to be used in connection with Hemisfair in 1968.

7. The construction date for the stone foundation and footing trench (Feature 4) identified during excavation at the site is still open to some debate. The size and shape of the prepared limestone blocks which comprised the feature are not consistent with the types of foundations norma $11 \mathrm{y}$ associated with jacal and palisado construction or rammed earth structures. This feature is too massive, extending nearly $1 \mathrm{~m}$ into a prepared footing trench, to be associated with a jacal or palisado type of structure, based on other excavations in the downtown area. Feature 4 probably represents the foundation for a $1-1 / 2$ or two-story structure, and may very we 11 be a portion of the Canterbury-Riddle homestead.

The preliminary archival research has shown that there are several gaps in the deed records pertaining to NCB 155, Lot 6 , that will require additional: research. One of these gaps involves the Canterbury-Riddle ownership of Lot 6 from 1858 to 1896. It is not known what year the Canterbury-Riddle homestead was built on Lot 6 ; it could not have occurred before 1858. There are still some conflicting documents which make it difficult to positively establish if the structurementioned in an 1880 deed is the same structure torn down as part of the 1927 widening of East Nueva Street. Another uncertain area in the deed records involves the period of the Delgado-Smith ownership of Lot 6 (1834 to 1848). It stil1 seems $p 1$ ausib 1 e, but yet to be proven, that someone resided on the lot during 1835 and 1836; several of the adjacent lots were occupied during this time.

The historical research has shown that the deposition of the artifacts recovered at La Villita Earthworks would have occurred.prior to the construction of the Canterbury-Riddle homestead. The shortest period of deposition for these artifacts, based on the present evidence, would have been 22 years (1836-1858). We have several additional documents in need of further verification which might cut the period of deposition to just nine years (1836-1845). 
REFERENCES CITED

Appler, J. A.

1927-1928 General Directory of the City of San Antonio. San Antonio, Texas.

1933-1934 General Directory of the City of San Antonio. San Antonio, Texas.

Bexar County, Texas

Bexar County Archives

Originals and microfilm located in the basement of the Bexar County Courthouse, San Antonio, Texas.

Bexar County Deed Records (BCDR)

Originals and microfilm located in the Bexar County Courthouse, San Antonio, Texas.

Bexar County Probate Minutes (BCPM)

Originals and microfilm located in the basement of the Bexar County Courthouse, San Antonio, Texas.

Chabot, F. C.

1937 With the Makers of San Antonio. Artes Graficas, San Antonio, Texas.

Corner, W.

1890 San Antonio De Bexar. Bainbridge and Corner, San Antonio, Texas.

Fox, A. A., F. Bass, Jr., and T. R. Hester

1976 The Archaeology and History of Alamo Plaza. Center for Archaeological Research. The University of Texas at San Antonio, Archaeological Survey Report 16.

Fox, D. E.

1983 Traces of Texas History: Archeological Evidence of the Past 450 Years. Corona Publishing Company, San Antonio, Texas.

Fox, D. E., F. Valdez, Jr., and L. O. Bobbitt

1978 An Archaeological Assessment of the Dolores Aldrete House Property San Antonio, Texas. Center for Archaeological Research, The University of Texas at San Antonio, Archaeological Survey Report 58. 
Garay, R.

n.d. Unpublished manuscript and notes on the location of the Spanish colonial structure known as the "Quartel." On file, Center for Archaeological Research, The University of Texas at San Antonio.

Giraud, F.

1848 City Plat Book. Vol. 1. Contains the original maps drawn by Giraud of the New City Block numbers in San Antonio. Copy located at the San Antonio Historical Preservation Office, City Hal 1 Annex, San Antonio, Texas.

Habig, M. A.

1939 The A1 amo Chain of Missions, A History of San Antonio's Five $01 d$ Missions. Franciscan Herald Press, Chicago, I1 1 inois.

Ivey, J. E.

1978 Archaeological Investigations at the Gresser House (41 BX 369), San Antonio, Texas. Center for Archaeological Research, The University of Texas at San Antonio, Archaeological Survey Report 60.

Katz, P. R.

1978 Archaeological and Historical Investigations in the Arciniega Street Area, Downtown San Antonio, Texas. Center for Archaeological Research. The University of Texas at San Antonio, Archaeological Survey Report 61.

Koch, A.

1873 Bird's Eye View of the City of San Antonio, Bexar County, Texas, 1873. Reproduced from the collection of the San Antonio Museum Association. Published by R. H. Holl and.

1886 Bird's Eye View of San Antonio, Bexar County, Texas, 1886, Looking Northeast. Reproduced from the collection of the Randolph Blueprint Company, San Antonio, Texas.

Labadie, J. H.

1986 Additional Archaeological and Historical Studies for the Fairmount Hotel Project in San Antonio, Texas. Center for Archaeological Research. The University of Texas at San Antonio, Archaeological Survey Report 160. 
Luckett, $B$.

n.d. Report of the Impossibility of the Stable Remains in N.C.B. 155, Lot 26, Being Originaliy a Spanish Fort. Manuscript on file, Office of the State Archeologist, Texas Historical Commission, Austin.

Maverick, M.

1939

01d La Villita. Published by the City of San Antonio, Texas.

\section{San Antonio City Directory}

1928-1929 Located in the San Antonio Main Public Library, San Antonio, 1957-1964. Texas.

\section{San Antonio Daijy Express}

1882 Untitled story about the stabilization of the foundation of the Canterbury homestead, January 28, 1882:4.

\section{Sanborn Map and Publishing Company, Ltd.}

1904 Map of San Antonio, Texas. New York.

Santos, R.

1967 The Quartel de San Antonio de Bexar. Texana 5(3):187-203.

Schuetz, M.

n.d. Archeology of the Quartel. Manuscript on file, Office of the State Archeologist, Texas Historical Commission, Austin.

Smith, J. D.

n.d. John.W. Smith Papers. Daughters of the Republic of Texas Research Library, Alamo, San Antonio, Texas.

State Historical Resources Inventory

1966 Criteria by which historic, architectural, and archaeological potential of sites in Texas are evaluated prior to nomination to the National Register of Historic Places.

\section{Texas Supreme Court Records}

Microfilm available for court cases originating in Bexar County, located in the Bexar County Courthouse, San Antonio, Texas. 


\section{CHAPTER 3 \\ STRUCTURE AND STRATIGRAPHY OF THE SITE}

Kenneth M. Brown

\section{GEOLOGIC SETTING}

Relatively little is known about the geologic and physiographic setting of the site. This part of San Antonio is very old, having altered and covered the terrain long before the advent of modern mapping. Indeed, it is at times difficult to be sure with any precision where the presettlement ground surface was. The site sits on a low terrace of the San Antonio River, outside of and 7 ess than $200 \mathrm{~m}$ to the south of a 1 arge angular meander of the river. The original surface of this terrace 1 ay at about 650 feet above mean sea level (MSL), and is estimated at about $30 \mathrm{~cm}$ below the city bench mark (651.05 feet MSL) on the curb at South Alamo and Nueva Streets. The terrace surface is therefore about $6.5 \mathrm{~m}$ above the bed of the river at the nearby Arneson Theater. The bulldozer excavation that preceded our field work left a 1 arge square pit about $3.0 \mathrm{~m}$ deep, with a relatively consistent stratigraphic section exposed in all the walls. Below the upper $30 \mathrm{~cm}$ or so, consisting of modern concrete and gravel fil1, about $2.7 \mathrm{~m}$ of Quaternary sediments (probably Holocene in age) were exposed. The upper $40 \mathrm{~cm}$ (approximately) consist of Houston Black clay, very plastic and dark gray brown in color, with a lower contact that is clear but very irregular. This is a thinner solum than that reported by Taylor, Hailey, and Richmond (1966:21) for other Houston Black soils developed on terrace sediments, perhaps indicating some of the topsoil has been removed in this area. Test pits dug in 1978 at the Caile and Dolores Aldrete houses next door (NCB 155, Lots $7,8,9)$ encountered this same dark brown sol1 as much as $60 \mathrm{~cm}$ be 1 ow the modern ground surface (Fox, Valdez, and Bobbitt 1978). The occasional prehistoric artifact found in our excavations in the fortification ditch may have been displaced from this soil zone. Below this soil is approximately $1.3 \mathrm{~m}$ of beige (10 YR 7.5/3) calichelike very calcareous sediment, with a somewhat gritty texture, frequently partially indurated, with scattered smal1 (up to about $2 \mathrm{~cm}$ in diameter) gravel that is predominately calcareous, but includes some chert. The lowest meter of the section is white chalky marl (10 YR 9/1). The highly calcareous nature of these sediments is a result of 01 mos Creek, the beginning of the drainage, heading in Edwards Limestone at the edge of the Balcones Escarpment.

\section{LOCATION OF THE SITE}

The initial bulldozer excavation (February 16-18) left an isolated "is 7 and" $10.6 \times 7.4 \mathrm{~m}$ in size, with the 1 ong axis running east-west, standing about 2.35 to $1.45 \mathrm{~m}$ above the floor of the bul1 dozer excavation (these figures are reconstructed and are not exact). The north face of the is 1 and was $14.9 \mathrm{~m}$ from Nueva Street and the east face, $9.4 \mathrm{~m}$ from South Alamo Street. The surface of the island sloped east and south from about $100.10 \mathrm{~m}$ (profile, north face) to about $99.19 \mathrm{~m}$ or 1 ess (at $\mathrm{N99}$ E104; these elevations are in terms of our arbitrary datum of $100.00 \mathrm{~m}$ set $74 \mathrm{~cm}$ below the city bench mark 
on the curb). This is a difference of about $91 \mathrm{~cm}$. Thus, the surface from which we began hand excavation lay about 0.65 to $1.56 \mathrm{~m}$ below curb 1 evel, and was therefore far enough below the original ground surface to have removed any possible evidence of a parapet associated with the fortification ditch. The bulldozers continued cutting down around this island, on February 17 and 18, to a final floor at about $97.75 \mathrm{~m}$.

\section{LAYOUT OF THE EARTHWORKS}

Our excavations revealed a substantial hand-dug ditch, presumably flanked at the time of the siege by a parapet built of fill taken from the ditch. However, since our investigation began at a grade below the old ground surface, nothing was left of the parapet itself, and we cannot even be sure on which side of the ditch it 1 ay. In this report, then, the term "earthworks" will general1y refer just to the ditch.

The ditch appears to have been L-shaped, with the longest leg running east and west, oriented approximate 1 y N $84^{\circ} \mathrm{E}$, and $9.25 \mathrm{~m} \mathrm{long}$. Our excavations 1 ocated both ends fairly accurately. Width of the surviving part of the ditch was about 1.3 to $2.75 \mathrm{~m}$. In plan view it seems to narrow toward the east end, but this evidently results more from the eastward-sloping surface of the bulldozer cut than from the actual design of the ditch. The design of the north leg of the $L$ is in large part conjectural, because very 1 ittle hand excavation was done here. My reconstruction of the extent and shape of this part of the ditch is based chiefly on two pieces of evidence:

(1) the profile of part of the north end, showing in the north face of the is 1 and (Figs. 9; 13,a);

(2) our observation of successive bul1dozer cuts in this area on March 1, as the last of the fill was bulldozed out.

The northern leg may have been roughly square, and projected about $3.45 \mathrm{~m}$ north from the north face of the east-west ditch. Its northeast corner shows in the north profile. Its width is not precisely known, since one of the pits dug to 1 ay a foundation py 1 on for the post-1927 gas station disturbed the area of the northwest corner. Although we have 1 ittle information on the actual floor or walls of the ditch in this area, we at least know that deeply buried, dark gray household refuse ( $V i l l i t a ~ F i l l)$ was extensive in the area-that much was conclusively established by watching the bulldozer.

The floor of both legs of the ditch 1 ay at $98.54 \mathrm{~m}$ as measured in the profiles. Other elevations measured near N100 El0I and N98 ElOI were 98.6I and $98.59 \mathrm{~m}$, respectively. The floor, then, seems to have been fairly flat and quite level, and 1 ay about $2.2 \mathrm{~m}$ below curb level, or about $1.9 \mathrm{~m}$ below the presumed original ground surface (Figs. 8, 9, 10).

Since anywhere from $35 \mathrm{~cm}$ to $1.25 \mathrm{~m}$ of fill had al ready been removed from the original grade either by the bul1dozers or by 1 ate 19th-century/20th-century disturbances, we cannot be sure what the upper part of the earthworks looked like and, therefore, we cannot accurately estimate the volume of fill originally excavated to create the feature. If the upper walls sloped 


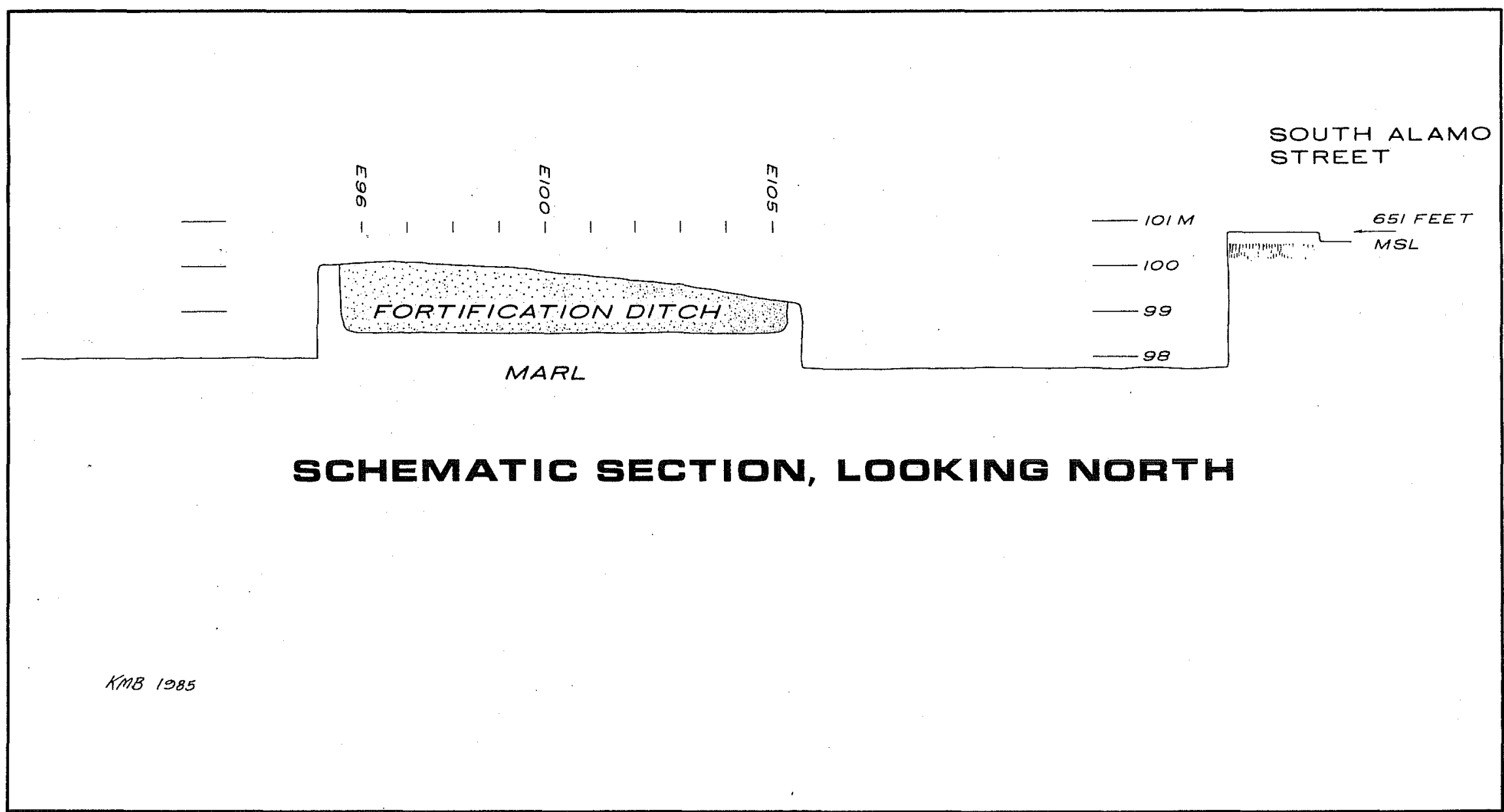

Figure 8. Schematic Section of the Site, Looking North. 


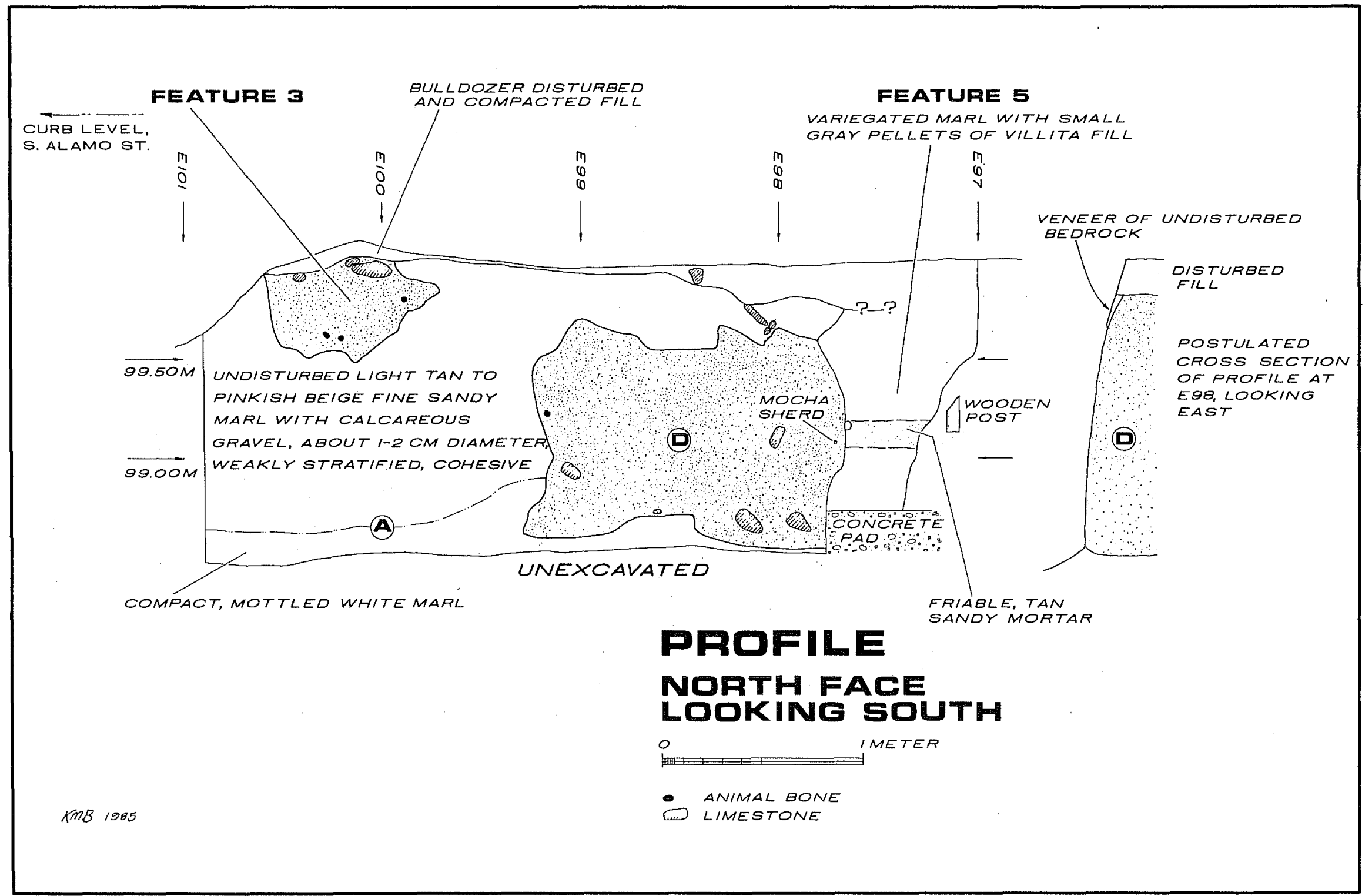

Figure 9. Profile of Part of North Face of Island, Looking South. This view shows the north end of the ditch apparentiy covered at the top by a thin veneer of undisturbed bedrock marl. The inset to the right of the profile shows a hypothetical cross section at a right angle, along the E98 grid 1 ine, of this unexcavated area. Stratigraphic units are: $A$, undisturbed bedrock; D, Villita Fill in ditch. 


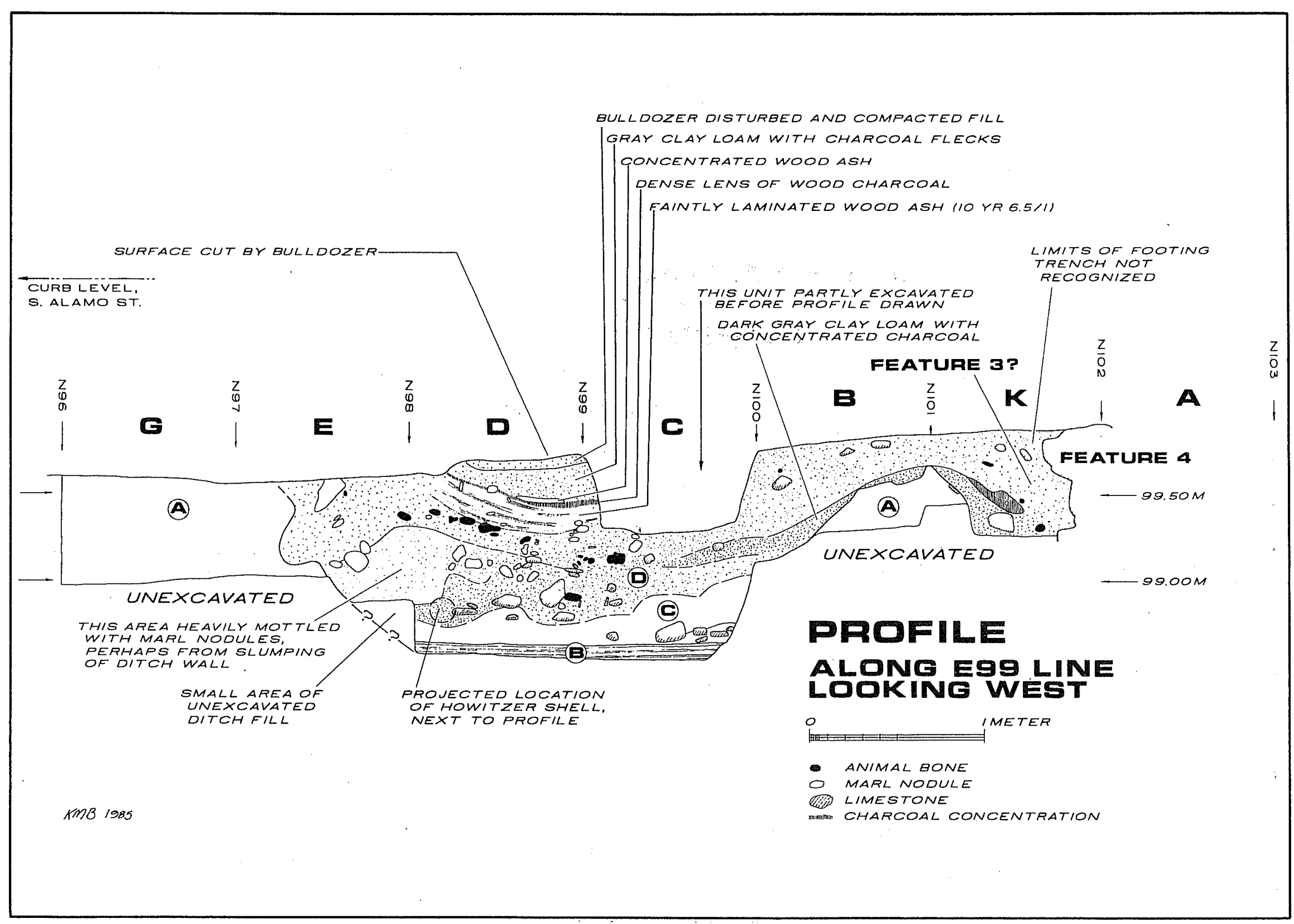

Figure 10. Profile Along E99 Line, Looking West. Letters above profile indicate units whose west walls comprise the profile. Circled letters indicate stratigraphic units: A, undisturbed marl bedrock; B, laminated marl; C, mottled marl; D, Villita Fill. 
outward somewhat, the volume may have been somewhat greater than the lower part would indicate. The somewhat irregular sectional form and $p$ lan form of the ditch also make estimation more difficult. However, we can at least arrive at a minimum estimate based on the surviving lower part of the ditch. If we assume the part east of the E99 1 ine had a regular outward 57 ope of $20^{\circ}$ from the vertical and was $1.9 \mathrm{~m}$ deep, varying in average width from about 1.5 to $2.0 \mathrm{~m}$ at the floor, we can calculate a volume of about $29 \mathrm{~m}^{3}$ for the eastern leg. Assuming the remainder of the ditch, as we suppose it to have 1 ain, averaged $3.0 \mathrm{~m}$ wide and about $5.7 \mathrm{~m} 1 \mathrm{ong}$, with vertical wal $1 \mathrm{~s} 1.9 \mathrm{~m}$ high (this is quite plausible, based on the contractor's excavations into the mar1), we can calculate a volume of about $35 \mathrm{~m}^{3}$ of fil1, giving a total volume of $64 \mathrm{~m}^{3}$.

From the project field notes it appears that we excavated and screened about $11.2 \mathrm{~m}^{3}$ of ditch fill (a smaller additional quantity of excavated fill represents either sterile marl bedrock or intrusive feature fill, or else was discarded without screening). As best we can determine, then, the ditch fil1 hand excavated and screened represents about $17.5 \%$ of the estimated amount of fil 1 that must have existed before disturbance.

\section{STRATIGRAPHY OF THE DITCH FILL}

The fortification ditch was dug into sterile marl and caliche identical to that exposed in the walls of the bulldozer excavation. The fill in the ditch consisted of three principal units, from bottom to top:

(1) Laminated white and gray marl. This unit was observed in the north-south profile along the E99 1 ine and was excavated in Units $C, D, M$, and $U$, a) though it was not recognized as a separate unit at the time. Its upper surface is level, and it varies from 6 to $10 \mathrm{~cm}$ thick, following a slight dip in the floor (Fig. 10). Curiously, it does not show in the north profile (Figs. 9; 13,a) even though the floor there is at the same elevation. This stratumi evidently represents a thin deposit of marl washed from the walls of the ditch by a rainstorm, and it is about the only indication we have that the ditch experienced any weathering before it was filled. A thin zone (perhaps 3-5 cm or more thick) of dark brown organical1y stained fill was found immediately over the floor of the ditch along the north side of Unit $M$ and in its northeast corner. This zone served as a conspicuous marker for the floor of the ditch wherever it occurred, but was not found elsewhere in the unit or in any of the adjacent units (Units $C, D$, or $U$ ). The source of the organic staining is unknown. Since this unit was recognized only in profile, if any artifacts were recovered from it they were included with material from the overlying "Parapet backfill" stratum.

(2) Mottled marl and caliche. This stratum consists of marl dug out when the ditch was first created, probably piled alongside to form a parapet, and 1 ater shoveled or allowed to slump back into the ditch. The granular texture and 1 ack of 1 amination suggests it was not simply washed onto the floor 1 ike the stratum below. It is about 10 to $40 \mathrm{~cm}$ thick, banked up against the north face of the ditch, and contains scattered wood charcoal; in fact during excavation, it appeared that the overlying dark gray Villita Fill had infiltrated downward into this zone along cracks in the slumped blacks or 
peds of backfilled marl, giving this stratum a somewhat reticulated appearance when sectioned in plan view. Another apparently localized lens of mottled marl can be seen in the E99 profile, in the west wa 11 of Unit $E$ extending out from the south wall of the ditch and protruding into the Villita Fill. This might represent a section of the south wall that had slumped during filling of the trench with trash (Fig. 10).

Artifacts that were recovered from either or both of these two strata (the laminated marl and the mottled marl) include a number of banded slipware sherds (many from the same vesse1); some plain pearlware; various green, black, and blue hand-painted pearlware sherds; a black transferware sherd; a poorly lead-glazed Mexican soft paste earthenware sherd; a mirror glass sherd; a wine bottle sherd; some patinated sherds of a thin, clearglass vesse 1; some pale aqua bottle sherds; some smal1 strap jron and nails; a possible brick fragment (contamination?); some chert items (probably redeposited prehistoric artifacts); and a few animal bones. The artifact density, and especial1y the bone density, is much lower than in the villito Eill above. A few military items might be associated with these strata. A bayonet blade, missing the shank and cylindrical socket, was also found on top of the mottled marl at 98.93 m near the west edge of Unit L. Another bayonet, also missing the shank and socket, was found in Unit U, probably lying on top of or perhaps slightly above the mottled marl (the elevation was not recorded, but is bel ieved to be approximately $99.05 \mathrm{~m}$ ). This artifact may have been modified for use as a pike head. A Brown Bess musket trigger plate was found in the mottled marl at $98.71 \mathrm{~m}$ in Unit $U$.

Other items associated with these fill zones include some paper fragments with writing in black ink and a three-rock hearth associated with an iron pot or kettle, an iron knife blade, and a flagstone (possible comal?). This feature wi11 be described in more detail later in this chapter.

Another cluster of three 1 imestone rocks (one sma 11 and two 1 arge, up to $60 \mathrm{~cm}$ or more in length) was found in Units $D$ and $U$, resting approximately on top of the mottled marl at elevations of 98.90 and $98.68 \mathrm{~m}$. These showed no evidence of modification or hearth construction and were not saved.

We should point out here that neither the laminated marl nor the mottled marl units appear in the north face profile (Figs. 9; 12,a), nor were they definitely identified in the bulldozer cut running approximately along the E98.5 1 ine made on March 1. This might imply that the northern leg of the ditch was somehow protected from weathering, or there might be some other explanation that we do not understand.

(3) Villita Fill. This stratum consists of a thick deposit of Houston Black clay soil (10 YR 4.5/1) containing abundant animal bone and domestic refuse (dating about 1830-1850) from La Villita, along with most of the military hardware recovered from the site. This is believed to represent most 1 y a sheet refuse deposit scraped up somewhere in La Villita and redeposited over a very short period of time, perhaps to level out the ditch. The villita Eill is weakly stratified, appearing as festoon-shaped lensing dipping downward into the central depression left by the ditch (Fig. 10). The contact between the ditch walls and the dark Villita Eill is clear and sharp, with a pronounced color contrast, and there is very 1 ittle evidence of 
erosion of the upper wal1s. In the transverse profile along the E99 1 ine this deposit is a maximum of about $90 \mathrm{~cm}$ thick, but in the north face profile it is at least $110 \mathrm{~cm}$ thick and may actually have been $1.45 \mathrm{~m}$ or more before obscured by 1 ater disturbances. The total thickness is, of course, unknown since some of the Villita Fill was doubtless truncated by bulldozing just as the presumed Parapet $\mathrm{E} i \mathrm{ll}$ must have been.

The Villita Fill includes both scattered marl nodules or peds, and 7 imestone rocks of various sizes; a concentration of these can be seen in the profile just above the mottled marl (Fig. 10), and the field notes mention other concentrations of rock (for example, in Unit $M$ at 20-50 cm below grade) that seem to be nonstructural clusters scattered in the fill. Animal bone also tended to occur in concentrations or lenses in the fil1; quantities of bone vary considerably from one arbitrary level to another and from one excavation unit to another. Lenses and pockets of wood ash were also noted in the fill; a large festoon-shaped deposit of 1 aminated wood ash about $15 \mathrm{~cm}$ thick can be seen in the E99 profile in Unit D, underlying a thin lens of solid wood charcoal. This charcoal lens was an extensive one, covering Units $C, D, J$, $P$, and perhaps parts of other adjacent units as we 11, giving it an area of at least $2 \mathrm{~m} \times 3 \mathrm{~m}$. There was $1 \mathrm{ittle}$ evidence of in situ firing of the fill underneath the charcoal sheet, suggesting it may have been dumped rather than burned in the ditch; but the evidence is not unequivocal. The integrity of these assorted pockets and lenses of ash, charcoal, and bone is an important point to consider, because if we find the deposits to be we 71 homogenized, it probably indicates the filling of the ditch was both intentional and of short duration--perhaps a single episode, or at most a few related episodes of filling. Ceramic cross-mending may help us here. If, on the other hand, examination of the field notes and artifacts suggests the fill is a composite of various distinctive dumped loads of trash, al1 retaining a fair amount of integrity, a more prolonged (and perhaps less purposeful) history of filling may be indicated.

In contrast to the marl units below, the villita Fill is profusely 1 aden with trash. Several major classes or groupings of items can be discerned:

1. Food remains: animal bone (cow, horse, pig, goat or sheep, dog, chicken, deer, etc.) and occasional freshwater mussel shelis (probably mostly Lampsil is sp.);

2. Discarded domestic items probably of Anglo derivation: English ceramics, pressed glass, wine bottle sherds, spoons, a bone-handled razor or clasp knife, a key, buttons, buckles, and so forth;

3. Discarded domestic items probably of Spanish colonial or Mexican origin: tin- and lead-glazed or unglazed ceramics, copper kettle fragments, a copper chocolatera, molcajete and pestle fragments of volcanic rock, and a clay whistle;

4. Discarded or misplaced religious items: a candelabra, pewter bel1, blue glass crucifix, blue faceted (rosary?) beads;

5. Rossible pharmaceutical items: fragments of small glazed mortars; 
6. Easteners: nails of various sizes, an iron spike, a brass tack, iron staple;

7. Horse gear: bits, a stirrup, spur rowe1; horse, pony, or mule shoes; some of these of probable Mexican origin;

8. Eirearm-related items, either military or civilian: these are likely to be military, and include oval lead sheets (gunflint pad blanks[?] not bale seals[?]), lead scrap, and gunflints (nearly a 71 of 1 ocal origin), including one French pistol flint; musket bal1s (a few with sprues attached); and pistol or rifle bal1s;

9. Knifeblades: unidentified as to military or civilian origin;

10. Probable military items: a possible Baker rifle barrel, a complete Brown Bess bayonet with a bent tip, another tip fragment from a bayonet (with cloth impressions preserved by the rust), a trigger plate, frizzen, frizzen spring, possible lock part, a musket butt plate, sword basket hilt, grapeshot, probable canister shot, and a howitzer shell fragment;

11. Qccasional prehistoric artifacts: flakes, bifaces, and a Guadalupe tool fragment;

12. Incidental mollusca: three conch she11s, freshwater mussel shel 1s, and snails of the genera Rabdotus, Polygyra, Helicina, Praticolel 1a, Physa, and possibly Helisoma, the last two aquatic;

13. Items of unknown function and derivation: including such items as whittled bone pins, iron washer, iron ring, threaded brass rod, brass ferrule, iron socket with wooden staff impression, and circular chipped stone discs.

Even this 1 ist, as complex as it seems, does not convey the bewildering variety of debris in the villita Eill. The most important division, however, seems to be between domestic trash and military debris. It is important to note here that nearly all of the military debris comes from the Villita Ejll, not from the 1 aminated or mottled marl zones. Musket balls of suitable military caliber, for example, are fairly common yet none of them seem to have been found in the marl zones. An unexploded 8-inch bronze howitzer she 17 and a smal1 iron round shot were found $1 \mathrm{ying}$ at about $98.76 \mathrm{~m}$, just above the top of the mottled marl in Unit $D$, enclosed by a sma 11 amount of Villita Eill and overlain by a lens of marl which might represent a section of slumped wal1 (Fig. 10). Only one artifact, a trigger plate from Unit U, Level 12, seems well associated with the marl zones; other than this, there are as noted above two bayonets which seem to be right on the contact between the marl zones and the villita $\mathrm{Fill}$. This 1 ack of association between the ditch floor and the military artifacts should not be taken to indicate that we have misidentified the ditch as a fortification trench; rather, it simply means that our primary argument for function should come from the layout and placement of the ditch and from what we can find in the written records. 


\section{FEATURES: INTRUSIVE AND OTHERWISE}

No feature numbers were assigned in the field, but I have numbered the most important ones for this report. The fortification ditch itself will not be numbered (Fig. 11).

\section{Eeature 1: Hearth}

A hearth was found against the north wall of the east-west fortification ditch, in a smal1 curving alcove formed by the original wal1, near the east end of the ditch (Fig. 11). It lay in Unit $X$, perhaps slightly above the original floor of the ditch. The wall of the ditch was actually undercut slightly just north of the hearth. The feature consisted of a more or less circular deposit of wood ash and charcoal, perhaps $30 \mathrm{~cm}$ in diameter, the top surface of which 1 ay at $98.84 \mathrm{~m}$, probably representing an in situ fire. Three (or perhaps four) 1 arge 1 imestone boulders (Fig. 12,a) had been rolled up to and partiy over the ash deposit, perhaps when the fire had died down to embers, for the ash deposit extended under the rocks, which were arranged in a triangular configuration. A concentration of charcoal about $10 \mathrm{~cm}$ in diameter was visible in the center of this arrangement. A few smali bone fragments were found immediately around the ash deposit. The tops of the rocks 1 ay at $99.02,98.97$, and $99.02 \mathrm{~m}$, with the bottoms at $98.84,98.85$, and $98.82 \mathrm{~m}$, respectively. These rocks were collected, and are about $26-28 \mathrm{~cm}$ in diameter. A few smaller fire-cracked rocks about $10 \mathrm{~cm}$ in diameter were also scattered about. After the rocks were removed, the ash deposit was troweled down, and $3 \mathrm{~cm}$ below the surface of the ash deposit a circular rust-stained ring appeared, $30 \mathrm{~cm}$ in diameter and with a wall thickness of $3 \mathrm{~cm}$ (Fig. 12,b). A smal1 iron square nail was found 1 ying on top of the rust stain on the north side. The stain proved to be a badly rusted iron pot or kettle, too deteriorated to remove intact, centered exactly beneath the ash and rocks above. It was cross-sectioned with a small trench, the fill being removed on the south side, and it was found to be $10 \mathrm{~cm}$ deep, its base resting at $98.71 \mathrm{~m}$. Wood ash and charcoal were found surrounding and filling this artifact, but not under it. A concentrated deposit of wood ash was visible in the bottom of the vessel.

Other items associated with this hearth were a rusted iron knife blade 1 ying at $98.89 \mathrm{~m}$ next to one of the rocks ( $F \mathrm{ig} .11$, item 12), and a large limestone flagstone lying west-southwest of and immediately adjacent to the hearth, at the same level as the ash deposit. This flat 1 imestone slab, which we at first supposed might be a coma 1 , is $30 \times 27 \mathrm{~cm}$ and $4.5 \mathrm{~cm}$ thick, with no visible heat discoloration. One slightly convex side has a smooth, worn feel. Conceivably this might have been a paving stone or flagstone worn by foot traffic, and commandeered as an expedient comal but not heated enough to show fire damage. It does not appear to be a metate. Another knife blade was found about half a meter to the east in Unit $T$, but since we have no elevation data other than the fact that it was found in Leve1 3 , we cannot determine whether it was associated.

The exact stratigraphic position of this feature is uncertain. Marl appeared in the base of our cross section trench at $98.71 \mathrm{~m}$, but this presumably was marl backfil1, not the trench floor, which was measured nearby with certainty 
Figure 11. Plan of Excavations. Hatched 1 ine shows approximate 1 imits of the fortification ditch at the surface left by bulldozing. Numbered items are as follows:

1. iron knife blade fragment;

2. iron stirrup;

3, Brown Bess bayonet;

4, candelabra;

5, unexploded 7-inch howitzer shel1;

6. 6-pounder(?) iron solid shot;

7. 9-pounder iron solid shot;

8, iron pike head or bayonet modified as pike head;

9. Brown Bess bayonet blade;

10. cabinet drawer pull backplate(?);

11. iron rod, 9 feet 4-1/2 inches 1ong, 5/8-inch in diameter (wagon brake tie rod?);

12. iron knife blade fragment;

13. iron oxide stain from pot or kettle;

14, iron knife blade fragment;

15. possible Baker rifle barre1. 


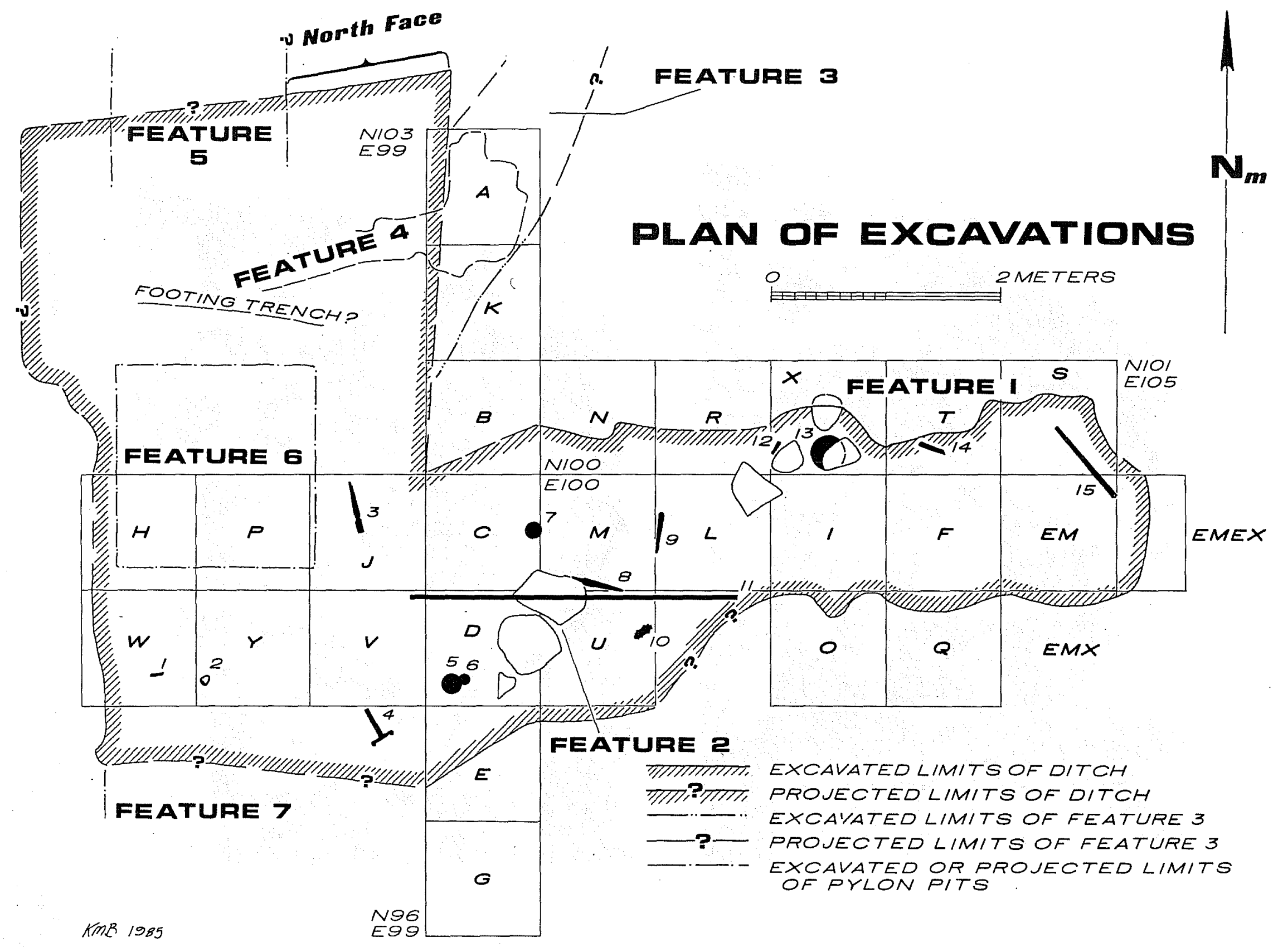

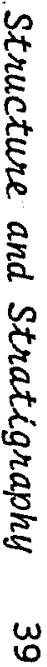



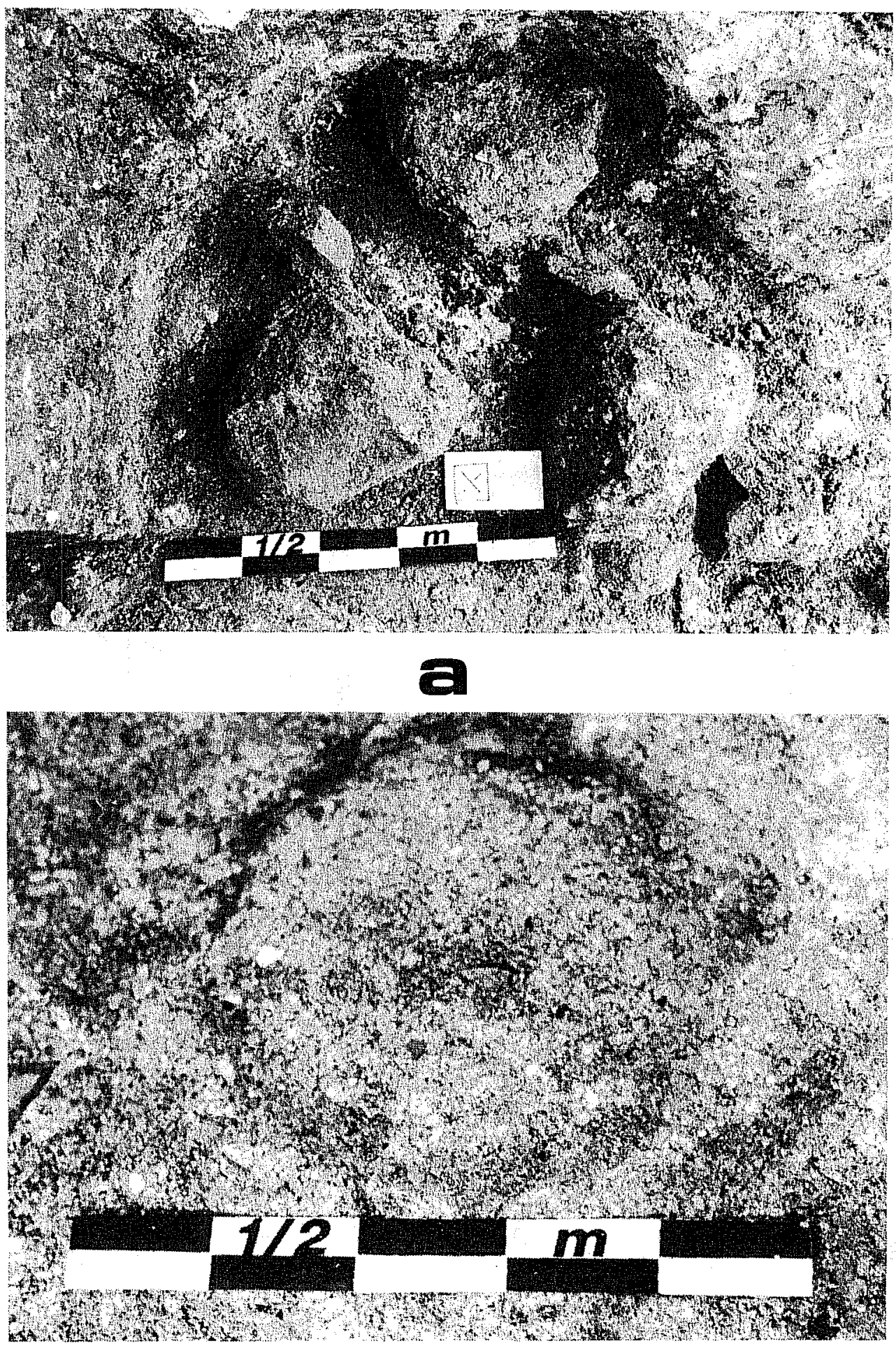

Figu̧re 12. Feature 1, Hearth. a, looking down and north at hearthstones exposed; note north wall of ditch at top right of photograph; b, iron oxide stain found under hearthstones, marking top of buried pot or kettle; looking down and north. 
at 98.61 and $98.59 \mathrm{~m}$. Of course the floor may have 1 ain slightly higher in this alcove; further excavation would have clarified this point. Thus we cannot be sure whether the feature lay on the ditch floor and was associated with its initial use, or was built in the backfill stratum associated with initial weathering of the trench. Color 51 ides show clearly that the possible comal was lying atop the mottled marl and is capped by the villita Eill.

As Anne Fox has pointed out, this feature is a classic example of the Mesoamerican three-stone hearth. Entries in the Handbook of Middle American Indians (Vogt 1969) show that this kind of hearth was distributed al 1 over native Mesoamerica, especially among the Maya of Guatemala and Chiapas, Tabasco, and Yucatán in Mexico. Other examples are recorded for the Amuzgo, Cuicatec, Popoloca, Ichcatec, highland Totonac, and Otomi, in the states of Oaxaca, Guerrero, Puebla, Veracruz, Hidalgo, and Queretaro. On the premise that this feature might have been built by soldaderas with the Mexican army, further research ought to investigate the distribution of this feature in northern Mexico, where it apparent1y occurred a 150, at 1east in Zacatecas and Aguascalientes (West 1974:116). Research on geographic recruitment of the Mexican army is also needed. The few documentary indications we have suggest La Villita was occupied mostly by militia from San Luis Potosi.

Assuming for the moment that this hearth was actually used during the siege in 1836, it is interesting to note that its position against the north wal1 of the ditch would give shelter both from a north wind and from hostile fire coming from the $A 1$ amo. The siege took place during a waning norther, and Almonte (1944:18-22) recorded weather data (cloud cover, Farenheit temperature, and wind direction) in his journal from February 25 onward, when the norther struck San Antonio with a strong north wind at 9 P.M. The 10 w was $39^{\circ} \mathrm{F}$ for the next two days, and $34^{\circ} \mathrm{F}$ the night of March 1 and the morning of the second, though a high temperature of $68^{\circ} \mathrm{F}$ was reached by the day before the assault. Weather 1 ike this might have prompted building a sma11 fire for warmth as well as cooking.

\section{Eeature 2: Rock Cluster}

Feature 2 is a cluster of two large 1 imestone rocks and one sma 11 one 1 ying chiefly in Units $D$ and $U$, but also extending into Units $C$ and $M$, apparently lying in the mottled marl zone close to the south wall of the fortification ditch. Scattered charcoal and small pockets of Villita Fill were found under the rocks, but there is no evidence that this represents a hearth 1 ike Feature 1. The rocks are $64 \times 48 \mathrm{~cm}, 54 \times 54 \mathrm{~cm}$, and $28 \times 16 \mathrm{~cm}$ in size, and the two whose elevations were recorded 7 ay at 98.90 and $98.68 \mathrm{~m}$.

\section{Eeature 3: Small Ditch}

Feature 3 is a smal1 ditch about $90 \mathrm{~cm}$ wide or 1 ess, and about $55 \mathrm{~cm}$ deep, running northeast-southwest and emerging in profile on the north face of the "is 1 and," where its bottom 1 ay at an elevation of $99.50 \mathrm{~m}$ (Figs. $9 ; 13, a$ ). The fill in this ditch is identical to the dark gray Villita Eill in the fortification ditch, and contains fairly abundant animal bone and charcoal. 

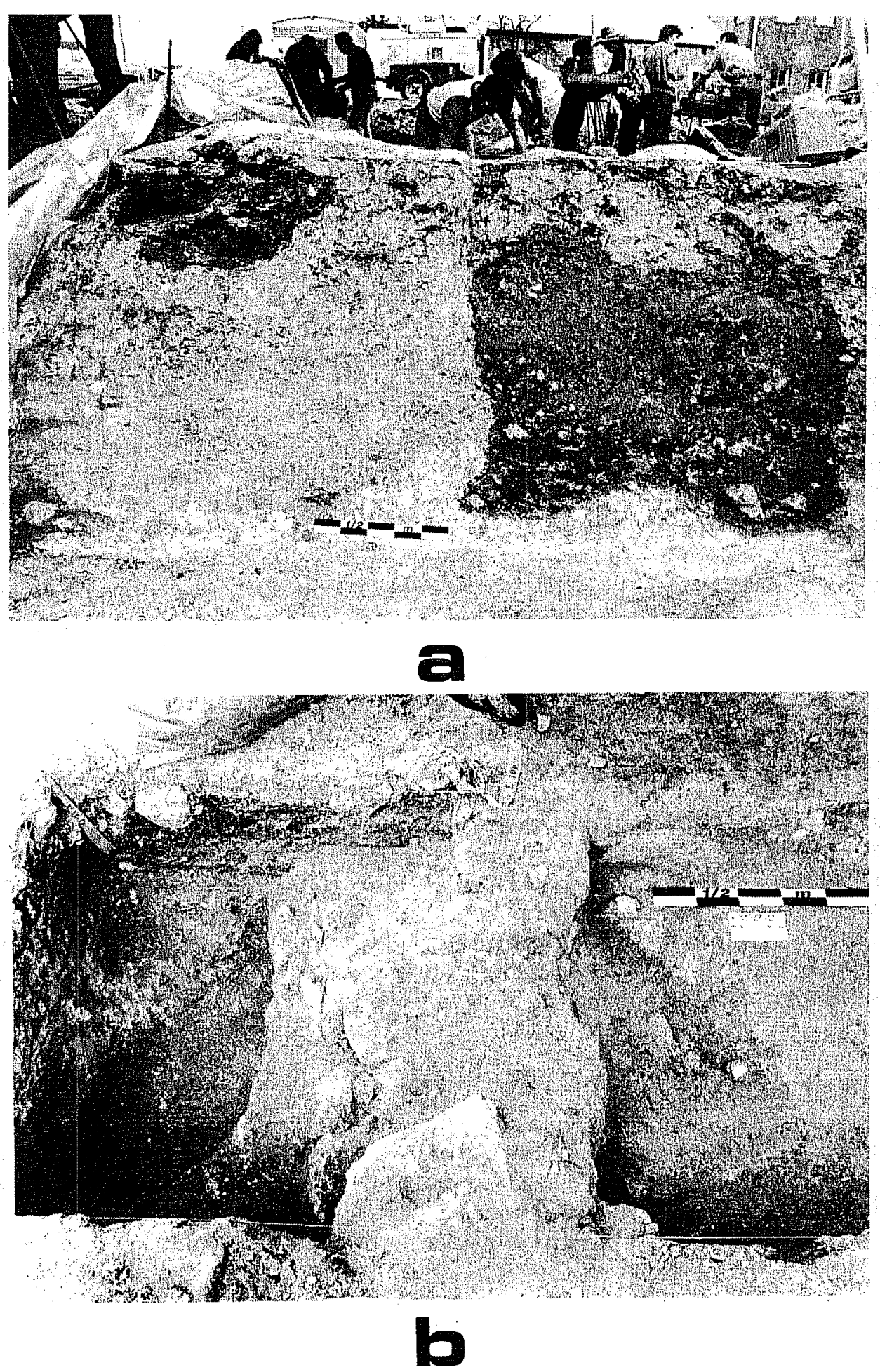

Figure 13. Profile of Part of North Face of Island; View of Feature 4 (Stone Foundation and Footing Trench). a, north face looking south; note dark Villita Fill in ditch and in Feature 3 (upper 1eft); b, looking down and east at excavation Unit $A$ to left and Unit $K$ to right; $f l$ ag marks grid point N102 E100. Feature 4, stone foundation, 1 ies in center. Triangular area of dark f111 to right may be part of Feature 3. 
This small ditch apparently ran across Units $A$ and $K$, where it evidently was intruded by the footing trench dug to set a 19th-century rock foundation (Feature 4). It is therefore presumed to be older than this structure, a) though whether it was contemporary with or more recent than the fortification ditch is unknown. In the profile along the E9g line (shown as Fig. 10) it apparently corresponds to that section of the profile immediately to the left of the foundation, extending south about to the N101 E99 grid point. A division between the footing trench fill (presumably more recent) and the small ditch fill (presumably older) could not be recognized here. In sum, both the purpose and date of this smal1 trench are unknown.

\section{Feature 4: Stone Foundation and Footing Trench}

A 7 ater 19th-century feature postdates both the fortification ditch and, apparently Feature 3 as we 11. It is 1 ikewise intruded by Feature 5 (see following discussion). It consists of a massive fieldstone (1imestone) wall foundation (Fig. 13,b), and where we were able to expose it well enough to examine it (in Units $A$ and $K$ and on the bulldozer-cut surface west of these two units) it seemed to be about $50-60 \mathrm{~cm}$ wide, mortared with a distinctively colored very sandy, loose, yellowish tan mortar. Not enough of this foundation was exposed to be certain of its exact ai ignment. We may have located a corner of the foundation in Unit $k$, since it seems to stop just short of the east wall of the unit, perhaps turning here to run north. The fieldstones in this area were especially massive, one in particular being at least 60 or $70 \mathrm{~cm}$ long (estimated). The base of this wall footing was not located by hand excavation, since none of the units in this area were dug deeply enough, but examination of color slides taken during the final bul1dozing suggests the base was at around 98.60 to $98.70 \mathrm{~m}$, rough 1 y $2 \mathrm{~m}$ below curb level on Alamo Street. Presumably this wall footing would have emerged on the west face of the island, but the profile was never cleaned off in this area to check for it. On the north face of the island, Feature 4 seems to have been intruded by Feature 5 (see following discussion).

\section{Feature 5: Northernmost Gas Station Pylon Pit}

A gas station stood on this b 1 ock by 1927 and remained unti 11939 or 1 ater. It rested on concrete slabs, or pylons, in which were embedded square lengths of iron reinforcing rod. The square pits dug to pour these concrete slabs intruded both the fortification ditch and the 19th-century wall footing, Feature 4. There were at least three of these pylons, the northernmost of which 1 ay at the north face of the island. The intrusive pit fill is shown in Figure 9; it contained variegated mar1, sma 11 pel1ets of gray yillita Eill, a zone of sandy tan mortar derived from Feature 4, and some mortar fragments evidently from the structure which stood on Feature 4; one of these had a 1 ayer of whitewash or plaster, coated with a pinkish-colored paint. From examining the fill, it is clear that Feature 5 intruded the fortification ditch, the marl bedrock, and the wall footing trench. 


\section{Feature 6: Middle Gas Station Pylon Pit}

A similar feature to the south of Feature 5 was visible in excavation Units $H$ and $P$ and immediately to the north on a hand-cleared surface at about $99.50 \mathrm{~m}$. The pit fi11 occupied most of both of these units as successive levels were dug, with the edges of the pit usually showing up well in plan view. In the upper levels the intrusive pit fill and the fortification ditch fill were not separated. The fill of Feature 6 contained red and yel low brick, red tile, glazed sewer tile, drawn and insulated wire, concrete, and other relatively recent artifacts, as well as occasional animal bone and early ceramics evidently derived from the $\mathrm{Villita}$ Fill and backfilled along with the more recent trash. Nodules of cream-colored marl were very abundant in the fil1, contrasting sharply with the remnants of dark gray villita Eill that were visible. In Level 7 in Unit $P$, the concrete 51 ab with square iron rebar was encountered. Feature 6 is rough 1 y $2.75 \mathrm{~m}^{2}$.

\section{Feature 7: Possible Southernmost Gas Station Pylon Pit}

On a hand-cleared surface at about $99.47 \mathrm{~m}$, to the south of Unit $W$, a possible disturbed area that had the same appearance and approximate alignment as Features 5 and 6 was noted. This is considered to be a possible third pylon pit. No hand excavation was done in this area, however.

\section{THE SEOUENCE OF EVENTS RECORDED BY THE DITCH FILL}

The stratigraphic information that we have seems to indicate the following sequence of events:

1. Excavation of the ditch through the existing topsoil and we 11 into the underlying marl "bedrock," to a level floor about $1.9 \mathrm{~m}$ below the ground surface. The backfill was presumably piled alongside as parapet material.

2. Brief weathering of the trench, indicated by about $10 \mathrm{~cm}$ of 1 aminated marl washed from the ditch wal1s and deposited as mud on the floor. This could have been accomplished by a single rainstorm. The north 1 eg of the ditch, however, seems to have been protected.

3. Slumping or backfilling of a small amount of the excavated marl into the trench. The amount replaced, however, was much less than that which had been taken out. Again, the north leg of the ditch did not receive any of this material. Feature 1 was built and used. Perhaps a hole was dug into the slumped marl to receive the iron kettle found under the hearth. Two discarded, broken or modified bayonets were apparently left on top of the slumped marl, and a musket trigger plate was left buried in it. A cluster of rocks (Feature 2) was dumped near the south wal1.

4. Filling of the ditch with Houston Black clay soil begins. This is topsoil obtained somewhere in the vicinity, but more of it is placed in the ditch than could be accounted for by erosion of the topsoll adjacent to the trench. There is 1 ittle or no evidence for erosion of the ditch wal1s, except perhaps for occasional slumping. Marl nodules occur in the fill, but 
lenses or 1 aminae of marl are absent. Curwen (1930) shows the degree of weathering that results in a similar calcareous substrate with more prolonged exposure. Mixed in with this dark soil are wood ash, charcoal, animal bone, domestic trash, and military hardware. Fill arrives in relatively discrete loads. A great many of the metal items recovered from this fill have remnants of grass or occasionally wood adhering to them, yet there is no indication grass was growing in the ditch floor. The evidence seems to indicate the ditch was filled too rapidly for a sod 1 ayer to form in the bottom. Perhaps the grass represents sod cut when the topsoil was collected to $f i 17$ the ditch. Whether filling reached the contemporary ground surface is unknown, since the upper deposits were removed by bul1dozing.

5. Possible capping by some sort of early structure(?); this is entirely conjectural; no archaeological or historical evidence has been found yet.

6. Intrusion by more recent disturbances (Features 4-7).

\section{TH-CENTURY CONVENTIONAL FIELD FORTIFICATION}

In order to provide a background for drawing conclusions about the structure of the site, let us review some of the basic elements of early 19th-century field fortifications.

Military engineering in the first decades of the century was rather highly conventionalized. Fortification design followed basic principles developed much earlier and elaborated by European theorists such as the Marquis Sebastien 1e Prestre de Vauban (1633-1707, French; see Rothrock 1968), the Baron van Menno Coehorn (1641-1704, Dutch), and Karl von C1 ausewitz (17801831. Prussian). There were mathematical formulas for computing the size of a ditch necessary to furnish earth for a parapet of given dimensions, formulas for computing the length of the parapets and area enclosed according to the size of the garrison, and rules of thumb for how much dirt could be moved by a pick-and-shovel team in a day's work. There were quite a number of textbooks and military dictionaries published both in Europe and in the U.S. Most of these were essential1y condensed or rehashed versions of authorities such as Vauban. Hoyt (1971; original1y published 1811) and Mahan (1968; originally published 1836) provide a good idea of the state of American knowledge at the time.

These basic principles ought as well to have been common know ledge in the Mexican officer corps, since many of them were Europeans or veterans of European service (Perry, trans lator and editor 1975:149). Knowing that we might expect siege works 1 aid out by the Mexican army to reflect some of this knowledge and convention, we searched during our excavations for evidence of it in the ground. As will be seen, there were few indications of the formal design that might have been expected. De 1 a Peña gives us a hint of the degree to which the Mexican army followed convention, at least when not hardpressed by the enemy or by Santa Anna himself. Speaking of the Tres Vil1as Battalion encamped at Lampazos Creek (Nuevo Leon?) on February 15, 1836, he remarks, 
The placements of their battery and of the units was so well done and in such accordance with the nature of the terrain, the tents of the commanders and officers formed such a beautiful perspective, that I was delighted at the sight of the camp. It is indeed a pleasant experience to see an encampment laid out according to the rules (Perry, translator and editor 1975:29).

There are also hints in the documents that protecting artillery with earthworks was standard practice, even in offensive situations. While we have some descriptions of the batteries that cos built before the first battle of the Alamo, Mexican accounts of the second battle do not give any descriptions of the earthworks that ringed the $A 1$ amo; but from the context it is clear that some sort of breastwork was erected. Almonte (1944:17), for examp 1e, records that on February 24 "very early this morning a new battery was commenced on the bank of the river, about 350 yards from the Alamo (Fig. 12). It was finished in the afternoon..." The fact that half a day was required for its construction suggests an earthwork of some substance was involved. Another instructive incident is detalled in a letter from Santa Anna to Torne1 (Castañeda 1971:73). When in hot pursuit of the Texians after the fal1 of the A1amo, Santa Anna found his crossing of the Brazos River at San Felipe opposed by a detachment behind a redoubt across the river, he "ordered a trench to be made facing the redoubt; and placing two six pounders behind it, we returned the fire..." At San Jacinto, Santa Anna again built breastworks for the artillery; most seem to have been fairly substantial, though one of these on the left flank of the Mexican force was rather expedient. An account by Col. Delgado, of Santa Anna's staff, notes "at daybreak on the 21 st his excel lency ordered a breastwork to be erected for the cannon. It was constructed with pack-saddles, sacks of hard-bread, baggage, etc. A trifling barricade of branches ran along its front and right" (Linn 1883:231).

\section{Design of Field Fortifications}

According to Mahan (1968:2),

- . the component parts of every intrenchment should consist of a covering mass, or embankment, denominated the parapet [author's emphasis], to shelter the assailed from the enemy's missiles, to enable them to use their weapons with effect, and to present an obstacle to the enemy's progress, and of a ditch [author's emphasis], which, from its position and proximity to the parapet, subserves the double purpose of increasing the obstacle, which the enemy must surmount, before reaching the assailed, and of furnishing the earth to form the parapet.

This definition applies to a defensive work, not a siege work. Since the work is expected to resist infantry attack, the ditch is placed on the hostile side.

The width of the ditch must be more or less, according to the thickness of the parapet: when the 1 atter is to resist musketry 
on $1 y, 8$ or 9 feet is sufficient, and the ditch may be of the same width.

If the parapet is to resist cannon, it must be 16 or 18 feet thick; this will require 18 or 20 feet for the ditch and berm (Hoyt 1971:36).

According to Mahan (1968:30),

Shot wi11 penetrate ordinary earth, when we 11 rammed, the distances laid down in the following table:

Musket bal1, .............. 1 foot 6 inches

6 pound shot,................... $31 / 2$ to $41 / 2$ feet

9 pound shot,.............. $61 / 2$ to 7 feet

12 pound shot, ................. $81 / 2$ to 10 feet

18 and 24 pound shot,............ $111 / 2$ to 13 feet

In order to insure the safety of the troops, these dimensions are augmented one half; so that no shot shall penetrate more than twothirds the entire thickness.

As to the height of the parapet, Mahan (1968:29) recommended

- . eight feet as the least height of parapet which will admit of a respectable defence. The greatest height has been fixed at twelve feet, owing to the difficulty of throwing up a work with the ordinary means at hand, which are usually only the pick and shovel.

On the interior of the parapet, a firing step or banquette was formed four feet three inches below the interior and two feet wide (unless two or more ranks were available to fire, in which case the width is four feet; Mahan 1968:32).

The ditch should be regulated to furnish the earth for the parapet. To determine its dimensions, the following points require attention; its depth should not be less than six feet, and its width less than twelve feet, to present a respectable obstacle to the enemy. It cannot, with convenience, be made deeper than twelve feet; and its greatest width is regulated by the inclination of the superior slope, which, produced, should not pass below the crest of the counterscarp (Mahan 1968:33).

In plan view, nearly all earthworks were supposed to form closed figures, for any substantial opening in the earthworks would jeopardize its defense. Occasional1y sma 11 works that were open to the rear might be constructed, such as a redan (Mahan 1968:18-19), arrow or fleche (Hoyt 1971:44), or lunette (Mahan 1968:19) designed to cover a point to the rear such as a bridge, but these were either to be covered by fire from another position or to be abandoned when hard-pressed. Small outworks of this kind which formed closed figures were termed redoubts. 


\section{Batteries}

Fixed artillery emplacements protected by earthworks were termed batteries. Batteries positioned along the 1 ine of a larger earthwork were usual1y stationed at à salient. If the artillery fired through an embrasure in the parapet, it was termed an embrasure battery; otherwise, firing over the unmodified parapet it was termed a barbette battery. According to Mahan (1968:80-81), a barbette

- . consists of a mound of earth, thrown up against the interior slope; the upper surface of the mound is level, or horizontal, and is two feet nine inches below the interfor crest for guns of smal1 caliber, and four feet for heavy guns. . . The perpendicular distance from the foot of the interior slope to the rear, should be twenty-four feet, to allow room for the service of the guns.... To ascend the barbette, a .. ramp [author's emphasis], is made. . ten feet wide at top, and its slope is six base to one perpendicular. . . The position of the ramp may be either on one of the sides or in the rear.

General1y a wooden gun platform was built as a floor for the artil1ery, since repeated recoil tended to rut the barbette. These were rectangular or trapezoidal, laid on large sleepers, and Mahan (1968:87) recommended a p 1 atform 9 feet by 15 feet for field guns and 10 feet by 17 feet for siege guns.

\section{FORTIFICATIONS IN THE FIRST BATTLE OF THE ALAMO}

The most useful primary sources (that is, accounts by actual participants) that mention fortifications in the first battle of the Alamo are Field (1836), Bostick (1901), and Johnston (1etter to Burleson, reprinted in Turner 1974:13-15). Sanchez Navarro (1960) and Ehrenberg (1968) give a fairly extended account of part of the batt 1e, but do not describe the fortifications in any detail. Yoakum (1935) presents a useful map and historical summary. Another useful source is an unpublished map housed at the 1 ibrary of the Daughters of the Republic of Texas (Figs. 14; 15). This pencil and ink map by Dr. Morgan Wolfe Merrick is titled "Rout [sic] of Johnson + Milam's Columns from Molino Blanco to Main P1aza" and is dated 1853. Merrick (1840-1911), a medical officer with the Confederate army during the Civil War, was apparent1y present in San Antonio before the war, during the war, and after, when he acquired local real estate through marriage with Victoria S. Veramendi.

From the accounts that we have it seems 1 ikely that the defensive works built by Cos in 1835 were more elaborate than the siege works built by Santa Anna's forces the following spring. Field (1836:16-17) recounts:

The village of San Antonio stands on the west bank of the river, of the same name, at a place where the stream by a sudden turn leaves a point of 1 and in shape resembling a horse shoe. Upon this peninsula it is said that David Crockett killed the first Mexican soldier, at the distance of two hundred yards. It was here that 
Crockett and Dickinson burned some houses that stood in the way of their artillery. That part of the town,... the centre of the military operations, is a square, enclosed on al1 sides by stone houses, parallel and at right angles with the sides of the square. At the entrance of every street, with the exception of that leading to the ATamo, a ditch was dug ten feet wide, five feet deep, raised on the inner side, so as to make an elevation of ten feet. Over this was erected a breast-work of perpendicular posts, with portholes for muskets, and one in the centre for cannon.

Elsewhere Field implies there were batteries not only at the northwest and northeast corners of the plaza, but at the other two corners as we17, "at each of which two cannon were placed" (Field 1836:21). Merrick's map, however, shows only the two batteries on the north side of Main Plaza. Sanchez Navarro (1960:51) refers to the breastworks at one point as "parapetos." Bostick (1901:90) refers to the breastworks as "barricades," seeming to confirm that some sort of palisade or revetment was employed:

The guns in these barricades were pointed down the street, and we were on each side in the houses. They could not turn the guns around so as to shoot at us, but we could shoot at them over the wa1 15 of the barricades, and when one of them crossed in front of a porthole we shot at him. We moved our cannon into a street so as to knock down some of the barricades....

According to Yoakum (1935), breastworks and batteries were established at the entrance of both Soledad Street and Main Street onto the Main Plaza, and a trench was established on the Alamo side of the river on the night of December 6 (see a 1so Johnston, in Turner 1974:14; and Ehrenberg 1968:88). Yoakum (1935) also refers to a "Mexican redoubt on the second block west of the main square" (see his map, position "L"). Johnston notes that the capture of the "priest's house" on the square on December 11 was done despite exposure to a battery of three guns and a large body of musketeers. Ehrenberg $(1968: 55,74)$ a 1 so mentions a battery of two 4-pounders set up on the roof of San Fernando Church.

Other entrenchments or breastworks were built by the Texan forces during the attack. Field mentions a house within 50 yards of the plaza, evidently on Soledad Street, which had a stone wall in the back yard reinforced with earth by Johnston's party so as to resist artillery fire from the Alamo. El sewhere he mentions "opening communications with each other by means of ditches" (Field 1836:20; see also Johnston, in Turner 1974:13). Field (1836:18) a1so describes "a ditch and breastwork upon the west bank of the river, within two hundred and fifty yards of the Alamo, and three hundred of the public square in the town" which was prepared as a battery for the Texans' 12-pounder.

The fate of all these fortifications, both Mexican and Texan, in January of 1836 is unclear. Colonel Johnston wrote the provisional government at San Felipe that he had ordered the fortifications in Bexar destroyed, but whether the order was executed is unspecified (letter, Francis Johnston, cited in Santos 1967:194). It is clear, however, that the Mexican works were clustered around the Main Plaza, with one trench between the Alamo and the river, and that the Texan entrenchments 1 ay north of the plaza, with one 
Figure 14. Map Showing Location of Mexican Entrenchments During the First and Second Battles of the Alamo, Along With Other Key Points. The street network is modern. Obsolete street names are shown in parentheses, except for Commerce Street, formerly known as the Alameda from the river eastward, and as Potrero Street to the west. Dashed 1 ines indicate vanished streets. The early 19thcentury river channel is shown, projected from a map by Gustavus Friesleben (undated, ca. 1845?) titled "San Antonio de Bejar \& Its Ancient Wards." Acequias are not shown except for the Pajalache Ditch. Marked points are as follows:

A, La Villita earthworks (41 BX 677);

B, Gresser house (41 BX 369);

C, southwest corner of Al amo compound, located by Radio Shack excavations;

D, Mexican battery at Veramendi house, 1836;

E. Mexican battery on Potrero Street, 1836;

F, Mexican battery near McMullen house, 1836;

$\mathrm{G}, \mathrm{H}$, Mexican batteries in the Alameda, 1836;

I,J, Mexican batteries at Main Plaza, 1835; question marks indicate possible additional batteries;

K. Wilson Riddle store.

Note that entrenchments north and east of the Alamo are not shown. 


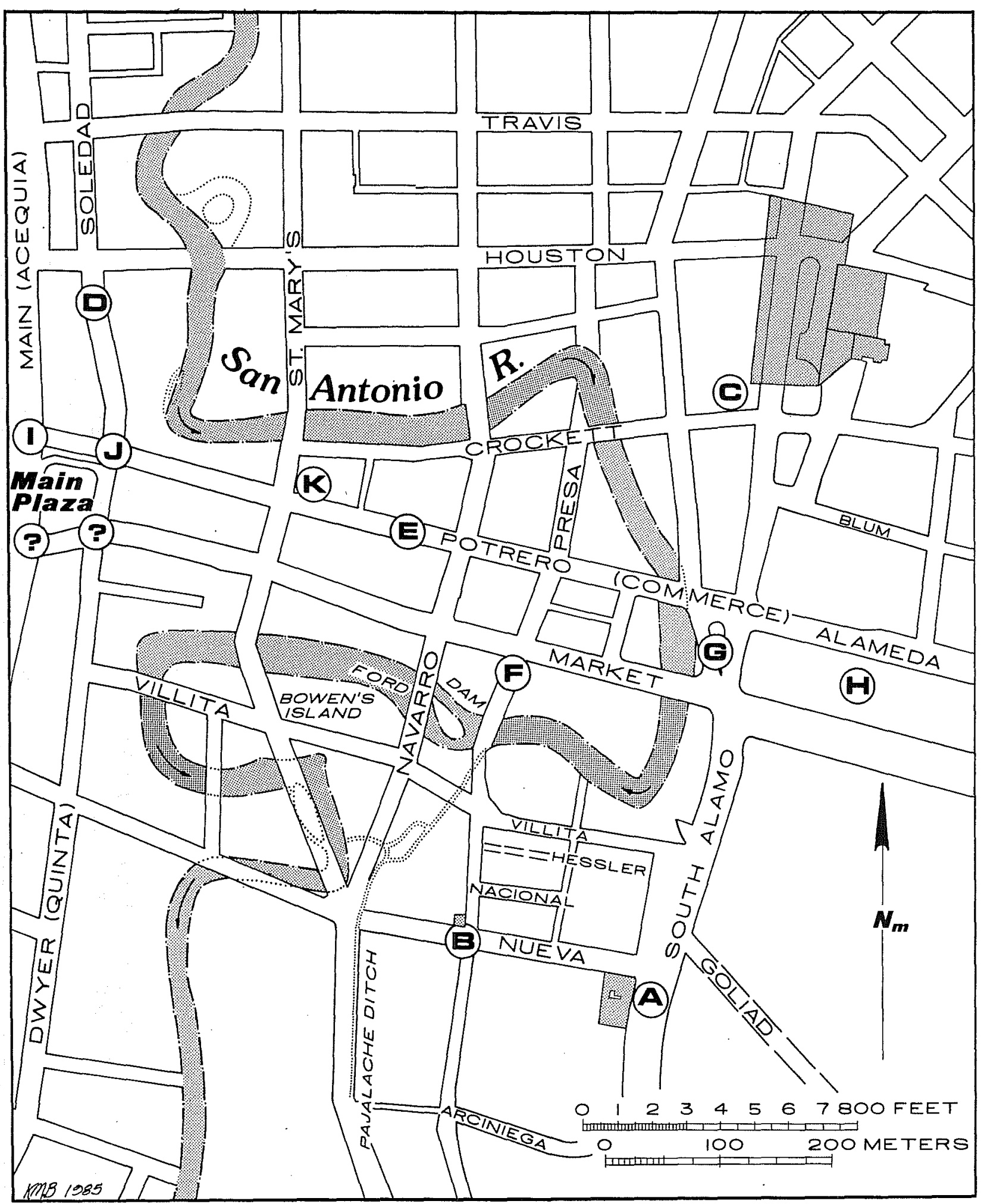




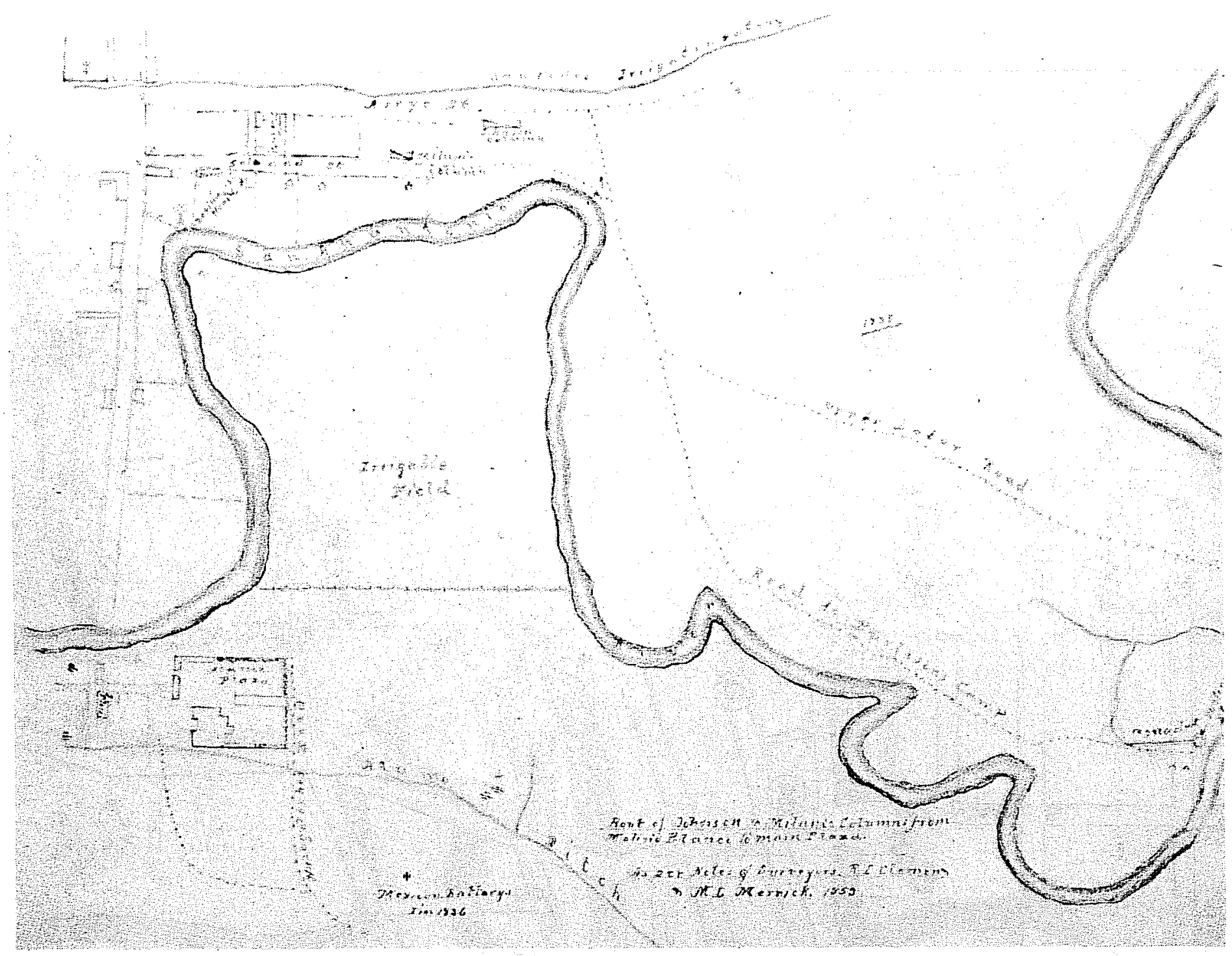

Figure 15. Part of a Manuscript Map by Dr. Morgan W. Merrick (1853), Entitled "Rout of Johnson + Milam's Columns from Mol ino Blanco to Main Plaza." While intended chiefly to show the disposition of forces in the 1835 battle, the map also bears inked battery symbols, with a key designating them as "Mexican Batterys in 1836"; note that the battery shown on the La Bastida map is al so shown near the Alamo Ditch. Batteries from the 1835 battle are shown in penci1. View is to the west. Reproduced by permission of the Daughters of the Repub1 ic of Texas. 
battery established on the west bank of the river (probably near or at the battery on Potrero Street set up by Santa Anna's forces in March; see the following discussion). There are apparently no references to entrenchments in La Vilita during the first battie.

\section{SIEGE FORTIFICATIONS IN THE SECOND BATTLE OF THE ALAMO}

Although in the case of the first battle of the Alamo, most of the detail on the outlying earthworks comes from the Texan accounts, the situation is different with regard to the second battle. As might be expected, the best (though sketchy) information on the location of the Mexican entrenchments comes from the Mexican accounts. The most useful eyewitness accounts are the journals of Almonte (1944) and de 1 a Peña (Perry, trans1ator and editor 1975), together with a few details drawn from that of Sanchez Navarro (1960, text and map), one of several newspaper interviews with Enrique Esparza (San Antonio Daily Express 1904), the account of Francisco Ruiz (cited in Williams 1938); the account of Becerra (1980), recorded 1 ate in 1 ife, is genera $11 \mathrm{y}$ considered unreliable and is of 1 imited usefulness. The wel1-known map of La Bastida (currently on display at the Witte Museum, San Antonio, Texas) is usefu1, but shows only the northeast Mexican battery. Dr. Merrick's (1853) map is an important source. A7though, as noted above, the map was intended primarily to 117 ustrate the 1835 battle, Merrick also shows at least three or four "Mexican Batterys [sic] in 1836" with ink symbols added to the map (Fig. 15).

The 1 ist following is an inventory of a 11 the Mexican entrenchments, whether for infantry or for artillery, insofar as it can be reconstructed from the fragmentary evidence left. The first Mexican artillery fire consisted of the four "grenades" (howitzer she $11 \mathrm{~s}$ ) evidently fired from Main Plaza in the afternoon of February 23 (de 1a Peña, Almonte); Sanchez Navarro (1960) implies some firing may have been done from this position as 1 ate as March 2, since he recounts seeing "granadas" 1 aunched from "the plaza" at 9 P.M.., though his viewpoint was Leon Creek far to the west. It seems unlikely any earthworks were used here, unless some of Cos' batteries remained from the previous months. The following numbered positions are 1 isted in approximate chronological order of construction.

1. At La Villita: On February 23, de 1 a Peña says "during the night some construction was undertaken to protect the 1 ine that had been established at La Villita under orders of Colonel Morales" (Perry, translator and editor 1975). Morales was commander of the San Luis Battalion of militia. Later, on February 26, A1monte recorded that the Texans burned "the 5 ma 11 houses near the parapet of the battalion of San Luis" on the left bank of the river.

2. Veramendi House: A1so on the night of February 23, "another sma 11 battery was made up the river near the house of Veremenda" (A1monte 1944; Fig. 14,D). This location, at Soledad and Veramendi Streets, may be the battery Esparza mentions "somewhere near where Dwyer avenue now is."

3. West bank of river: This is a battery set up on the riverbank 350 yards from the Alamo, begun early in the morning of February 24 and finished in the afternoon. Almonte does not say it was on the west bank, but the distance 
indicates it was on the Bexar side of the river. It is probably the "temporary fortification on Potrero Street" mentioned by Ruiz (Fig. 14,E), and is evidently the battery "V" shown on the Sanchez Navarro map, but 1 abeled as set up on March 1 (the date is evidently an error). Sanchez Navarro, possibly on about March 3, records in his journal that two batteries are present, one in Bexar near the river 200 toesas* $(334 \mathrm{~m})$ west of the Alamo, with an 8-pounder, a 6-pounder, and an "obus de 7 p." This is undoubtedly position 3 , though his map implies an extra field piece.

4. Above the Alamo: This vague reference comes from Becerra (1980), who said "a small work was commenced above the Alamo"; he may be referring to an entrenchment begun on the 24 th, but the date is unspecified.

5. Above the Alamo: Position 4 described above was finished the following day but did not suit Santa Anna, so he ordered another made closer to the Alamo under the supervision of General Amador, according to Becerra.

6. In the Alameda: According to Almonte, two batteries were erected in the Alameda (now Commerce Street) on the night of February 25, with the Matamoros Battalion stationed here. Both of these are indicated on the Merrick (1853) map south of Commerce Street (Fig. 14,G,H), with one of the batteries apparently located west of $A 1$ amo Street and the other just west of the Acequia Madre (north of the present Convention Center).

7. In the Alameda: The second of the two batteries.

8. McMullen House: Also on the 25th, according to Almonte, a "new fortification" was begun near the McMulien house (Presa and Market Streets, Fig. 14,F). This evidently would have been slightly to the southeast of the battery at position 3 .

9. "Mere trenches": According to Almonte, on March 1 Ampudia was "commissioned to construct more trenches," but this unhelpful entry does not say where, how many, or what kind.

10. North of the Alamo: A11 of the preceding works were begun before the arrival of the sappers from Aldama and Toluca. On March 3, Almonte records that a battery was erected north of the Alamo within musket shot; this may we11 be position 4 as recalled by the aged Sergeant Becerra.

11. Northeast of the Alamo: This position is the second of those mentioned by Sanchez Navarro in his journa 1, at a range of 150 toesas $(250.8 \mathrm{~m})$ and is shown on his map at "R" where he notes it was directed by Ampudia on the night of the 4 th and dawn of the 5 th (does he mean the 6th?). In the text Sanchez Navarro says it has four pieces similar to those at position 3 , although his map implies four field pieces and two howitzers. This is perhaps the best documented battery, as it is also shown on La Bastida's map at a distance of 245 Casti 11 ian varas (671.9 feet, or 121.5 toesas). It is probably also the pair of battery symbols indicated on the Merrick (1853) map adjacent to the Acequia Madre northeast of the Alamo.

*Note: toesa $=1 \mathrm{~m} 672 \mathrm{~mm}$ or 1 yard 30.3566 inches 
12. North of the Alamo: Almonte records on March 4 that "in the night the north parapet was advanced towards the enemy through the water course. A Lieutenant of Engineers conducted the entrenchment." This may we 11 be position 5 as recalled by Becerra, and it may also be the trench established to the northeast, half a musket shot from the Alamo described by Sanchez Navarro, using the Acequia Madre as a covered approach.

If we distill all of the above and try to eliminate redundancies and vague or unreliable accounts, we are left with the following as well-documented positions which probably or certainly involved some dirt-moving in their construction:

(1) Artillery positions: $2,3,6,7,8$, and 11 ; a total of six batteries.

(2) Infantry positions: 1, 4, and 5 (the 1 atter two, though 7 isted in the Becerra account, seem to be confirmed by Almonte); a total of three positions. Probably there were many more than these, but these are al 7 that were documented.

It is interesting to compare this inventory drawn strictly from the Mexican accounts with that of Potter (1878), made a few decades after the battle and drawn from interviews with Seguin. Bradburn. Becerra, and others. Potter 1 ists two artillery positions west of the river (either 2 and 3 or 3 and 8 ) and "seven more ... most of them on the east side of the river, and bearing on the northwest, southwest and south of the fort; but there were none on the east" (Potter 1878:6-7). His total is therefore nine batteries. In another interesting reference, Potter (1878:11) claims that during the assault, "Santa Anna took his station, with a part of his staff and a 11 the bands of music, at a battery, about 500 yards south of the Alamo and near the $01 \mathrm{~d}$ bridge," but no source is given for this assertion.

\section{FORTIFICATIONS DURING THE WOLL INVASION, 1842}

Woll's report of the battle at Bexar on September 12, 1842, indicates that the invasion force halted at the campo santo while the $A 1$ amo and "all points around the city" were occupied. Approaching the two plazas at the center of town, Woll "learned that a redoubt had been built and loophole openings made in the houses fronting the church and in others that formed the first block of the street leading to the Alamo." El sewhere he refers to the Texans as "entrenched and behind parapets" (Nance 1955:530-531). Again, as in the first battle of the Alamo, it is clear that the action took place in the central part of town, not in La Villita.

\section{FUNCTION OF THE SITE}

With all of the preceding as background, let us see what we can reasonably conclude about the function of the site. Four alternative hypotheses may be proposed, according to which the ditch may be considered:

(1) a gully, drainage ditch, or acequia lateral;

(2) a footing trench for a house; 
(3) an infantry trench, rifle pit, or redoubt;

(4) a battery.

Hypothesis 1: There is compe 11 ing evidence against this hypothesis. The ditch ends abruptly short of the east and west faces of the island, and unless we have misread the evidence on the north face, it seems to end abruptly there as wel1. For the most part there is no evident erosion of the walls or sediment in the fill, with the exception of the laminated marl zone observed on the floor in the central part of the trench. The ditch wall seen in the north profile is sharp, vertical, and uneroded, without any sediment appearing in the fil1. Al1 of the profiles we cut suggest that whatever erosion of the ditch occurred was of short duration and resulted in standing, not running water. Archaeological excavations of San Antonio's acequias have shown that the unlined parts are frequently shallower and general 1 y have sloping wal1s (see Frkuska 1981).

Hypothesis 2: The 1 imited extent of the ditch also argues against the idea that it is a footing trench, since a footing trench would be expected to form a closed figure, rather than an L-shape. Footing trenches would probably not be expected at a11 for the modest houses existing in La Villita in the early decades of the 19th century. The ditch is certainly too wide for a footing trench; the footing trench for Feature 4, for example, was probably not much wider than the foundation itself. No stonework (discounting Feature 2) or mortar was found in the undisturbed parts of the ditch, indicating that it is not a footing trench that has been robbed for its stonework.

Hypothesis 3: This hypothesis must be considered at some length, since it seems more plausible than the first two. We can rule out the possibility of its being a redoubt, since the known limits of the ditch are too small and do not form a closed figure. Because the site is beyond effective small arms range, we can perhaps discount it as an infantry siege work designed for direct fire against the Alamo. As an infantry position, it does not seem very defensible against sorties from the $A 1$ amo. It does not form a closed figure and would be vulnerable at the ends unless flanked by the parapet or by nearby houses. It is unfortunate that we do not know what structures might have stood on these 1 ots in the 1830s. The work seems too sma 11 in which to mass any significant number of troops, which perhaps means it would have to be simply a post for pickets, rather than something more substantial. The site seems to be positioned strategically so as to command both the Concepción. Road and the Goliad Road, but we do not know if a clear field of fire lay in that direction, and the orientation of the ditch seems wrong if it is sited so as to command the area to the northeast and east. It would probably command the river crossing at the Navarro Street bridge, if the houses in La Villita were not blocking the field of fire. A different orientation might be plausible if the site were associated with the first battle of the Alamo in December 1835, but the available accounts that we have (for example Bostick and Yoakum) indicate that action took place north of the river, between the Main Plaza and the Alamo. During the siege of the Alamo the following spring, de 1 a Peña records that on February 23, "during the night some construction was undertaken to protect the 1 ine that had been established at La Villita under orders of Colonel Morales." Morales was commander of the San Luis Battalion. Later, on February 26, the Texans burned "the sma 11 houses near the parapet of the battalion of San Luis" on 
the left side of the river. These two references seem to establish that some sort of breastworks was established in La Vil1ita for the San Luis Battalion.

Hypothesis 4: This hypothesis has significant arguments both for and against it. One significant argument against is that none of the historical accounts mention a battery this far south of the Alamo during the siege. Two batteries were reported erected in the Alameda (Commerce Street) on the night of February 25, 1836, with the Matamoros Battalion stationed there, but this is we 11 to the north of our site. This account mentions the parapet of San Luis, but does not say anything about artillery. Another possible negative argument is that the ditch does not correspond to the expected shape for a battery. Since the ditch would function mainly just as a borrow pit for the ramp and parapet, it need not correspond exactly to the shape of the earthwork, but it should correspond closely enough to obviate unnecessary dirt-moving. So far as we can judge from the remaining evidence the earthwork was rather ad hoc, probably indicating it incorporated, tied into, or in some way was $\mathrm{p} 7$ anned in relation to nearby standing houses. We know that a work party dismantled some houses in the area on February 23 , supposedly to build a bridge; perhaps they used some of the timbers for a revetment as we11. Perhaps the best argument for the battery hypothes is is that the work is of a compact size and is well within artillery range of the A1 amo, yet beyond effective sma11 arms range.

\section{SUMMARY AND CONCLUSIONS}

Excavations revealed an apparently L-shaped ditch, believed to be about $1.9 \mathrm{~m}$ deep, $9.25 \mathrm{~m}$ long east-west, with a wider northern leg extending about $3.45 \mathrm{~m}$ to the north (very 1 ittle excavation was done in this northern 1eg, and our knowledge of it is derived mainly from a profile and from observations of its removal by bul1dozing). The central part had laminated marl on the floor, suggesting short-term weathering, overlain by mottled marl apparently representing 1 imited slumping of backfill into the pit. Overlying this is the villita Eill, a thick secondary deposit of topsoil containing abundant domestic refuse and scattered military hardware.

The best available evidence we have now indicates the site is probably the remains of a military earthwork of some sort, presumably related either to the first or second battle of the Alamo. Since we have fairly detailed accounts indicating the Mexican positions were concentrated between Main Plaza and the Alamo, we can perhaps tentatively rule out the first battle. The available evidence is inconclusive as to whether the work was an infantry position or an artillery position. The apparent ad hoc nature of the construction means that we cannot rely on the shape of the ditch to help us recognize its function. Nor can we rely on the types of military hardware to help decide its function, since little or none of it is in primary association with the ditch (none of it, for example, was found on the ditch floor, although a few sherds of pottery were found).

Our best hope of learning the purpose and age of the site rests with (1) further research on archival sources and on the artifacts we have recovered; and (2) location and exploration of other sites of the same $k i n d$. One of these may 1 ie just south of the Gresser house, at South Presa and Nueva 
Streets, in an area tested by the CAR in 1977. In the south wall of a construction trench there appeared part of a ditch that may be very similar to the one we investigated at Nueva and South Alamo Streets (Ivey 1978:Fig. 4,b). This ditch was never investigated, so we know nothing about its extent or contents. It 1 ies just a block west of the site reported here.

\section{ACKNOWLEDGNENTS}

Special thanks to Sharon Crutchfield and the Daughters of the Republic of Texas for permission to reproduce the Merrick map. Thanks also to Cathy Dodt, who helped run a transit traverse from the San Antonio River to the site, and to Anne Fox, who pointed out the Mesoamerican significance of Feature 1.

\section{REFERENCES CITED}

Almonte, J, N.

1944 The Private Journal of Juan Nepomuceno Almonte, Feb. 1Apri1 16, 1836. Southwestern Historical Quarterly XLVIII(1): 10-32.

Becerra, F.

1980 A Mexican Sergeant's Recollections of the A1 amo and San Jacinto. As Told to John S. Ford in 1875. Jenkins Publishing Company, Austin.

Bostick, S. R.

1901 Reminiscences of Sion R. Bostick. Quarterly of the Texas State Historical Association 5(2):85-96.

Castañeda, C. E., translator

1971 The Mexican Side of the Texas Revolution (1836). Documentary Publications, Washington, D.C.

Curwen, $C$.

1930 The Silting of Ditches in Chalk. Antiquity 4:97-100.

Ehrenberg, H.

1968 With Milam and Fannin. Adventures of a German Boy in Texas' Revolution. The Pemberton Press, Austin. 
Field, J. E.

1836 Three Years in Texas. Including a View of the Texan Revolution, and an Account of the Principal Battles, Together with Descriptions of the Soil, Commercial and Agricultural Advantages, \& C. Justin Jones, Greenfield, Massachusetts.

Fox, D. E., F. Valdez Jr., and L. O. Bobbitt

1978 An Archaeological Assessment of the Dolores Aldrete House Property, San Antonio, Texas. Center for Archaeological Research. The University of Texas at San Antonio, Archaeological Survey Report 58.

Friesleben, G.

n.d. San Antonio de Bejar \& Its Ancient Wards. A1though undated, 1845 is the estimated date of the map based on documentary research. Photostat of the map is on file at the Center for Archaeological Research. The University of Texas at San Antonio.

Frkuska, A. J., Jr.

1981 Archaeological Investigations at the San Pedro Acequia, San Antonio, Texas. Center for Archaeological Research, The University of Texas at San Antonio, Archaeological Survey Report 103.

Hoyt. E.

1971 Practical Instructions for Military Officers: Comprehending a Concise System of Military Geometry, Field Fortification and Tactics of Riflemen and Light Infantry. Also the Scheme for Forming a Corps of a Partisan, and Carrying On the Petite Guerre, by Roger Stevenson, Esq. Revised, Corrected, and Enlarged. To Which is Annexed, a New Military Dictionary; Containing the French Words, and Other Technical Terms, Now Used in the Art of War; With Other Matter Connected With Military Operations. Greenwood Press, Westport, Connecticut (original edition John Denio 1811).

Ivey, J. E.

1978 Archaeological Investigations at the Gresser House (41 BX 369), San Antonio, Texas. Center for Archaeological Research, The University of Texas at San Antonio, Archaeological Survey Report 60.

Linn, J. J.

1883 Reminiscences of Fifty Years in Texas. D. \& J. Sadiier \& Co., New York. 
Mahan, D. H.

1968 A Complete Treatise on Field Fortification, With the General Out 1 ines of the Principles Regulating the Arrangement, the Attack, and the Defence of Permanent Works. Greenwood Press, New York (original edition Wiley and Long 1836).

Merrick, M. W.

1853 Unpublished hand-drawn map in pencil and ink, entitled "Rout [sic] of Johnson + Milam's Columns from Molino Blanco to Main Plaza. As per Notes of Surveyors. R.E. Clemen + D.M.L. Merrick. 1853," Original on file at the Daughters of the Republic of Texas Research Library, Alamo, San Antonio.

Nance, J. M., translator and editor

1955 Brigadier General Adrian Woll's Report of His Expedition into Texas in 1842. Southwestern Historical Quarterly 58(4):523552.

Perry, C., translator and editor

1975 With Santa Anna in Texas. A Personal Narrative of the Revolution by José Enrique de la Peña. Texas A\&M University Press, College Station.

Potter, R. M.

1878 The Fall of the Alamo. The Magazine of American History January issue.

Rothrock, G. A., translator

1968 A Manual of Siegecraft and Fortification by Sebastien Le Prestre de Vauban. University of Michigan Press, Ann Arbor.

\section{San Antonio Daily Express}

1904 Story of the Massacre of Heroes of the Alamo. Interview with Enrique Esparza, March 7, 1904.

Sanchez Navarro, C.

1960 La Guerra de Tejas. Memorias de un Soldado. Editorial Jus, Mexico.

Santos, R. G.

1967 The Quartel de San Antonio de Bexar. Texana 5(3): 187-203. 
Taylor, F. B., R. B. Hailey, and D. L. Richmond

1966 Soil Survey of Bexar County, Texas. United States Department of Agriculture, Soll Conservation Service, in cooperation with the Texas Agricultural Experiment Station, Series 1962(12).

Turner, M. A.

1974 Texas Epic: An American Story. Nortex Press, Quanah.

Vogt, E. Z,, editor

1969 Handbook of Middle American Indians. Vols. 7 and 8, Ethnology (Robert Wauchope, general editor). University of Texas Press, Austin.

West, R. C.

1974 The Flat-Roofed Folk Dwelling in Rural Mexico. In Man and Cultural Heritage, Papers in Honor of Fred B. Kniffen, edited by H. J. Walker and W. G. Haag:111-132. Geoscience and Man 5.

Williams, A.

1938 A Critical Study of the Siege of the Alamo and of the Personnel of the Defenders: II. Santa Anna's Invasion of Texas, and His Investment and Assault of the Alamo. Southwestern Historical Quarterly 37(1):1-44.

Yoakum, $H$.

1935 History of Texas From Its First Settlement in 1685 to Its Annexation to the United States in 1846. Steck Company, Austin (reprint of original edition). 


\title{
CHAPTER 4 \\ ANALYSIS OF MILITARY RELATED ARTIFACTS
}

\author{
Samuel P. Nesmith
}

\section{INTRODUCTION}

A 1 arge number of historical artifacts, which date from 1830 to 1850 , were recovered from La Villita Earthworks. A number of these artifacts were produced or manufactured to perform a strictly military function. Before discussing individual items, however, a general historical framework within which these artifacts have been analyzed is presented, including the types of weaponry, field artillery, ammunition, and personal items with which the Mexican army of 1836. was equipped. Following this short historical overview, a detailed description of the recovered materials is presented.

\section{HISTORICAL BACKGROUND}

By the second decade of the 19 th century, the Mexican military system was tired. It had been tested by 20 long years of revolution and bloody civil war. The Spanish army had been the proving ground of the senior officer corps, and most of the field officers had gained their experience through the colonial army and the Mexican wars for independence. Now that independence had been gained, there was time for rebuilding. The new army adopted the Spanish influence in tactics, ordnance, armament, and drill (Nieto, Brown, and Hefter 1958:50). During this time, replenishments were also obtained of new foreign material to bolster the surviving Spanish munitions of war and the meager production of Mexican factories. In the successive years after the Napoleanic era, the Mexican army showed their respect for the combatants in the adoption of French military fashions and British ordnance (Hefter 1968:60). Besides, in this period of European military surplus, there were great bargains to be had.

Their first concern for American interest in Texas had begun in 1801, when it was feared by the Spanish authorities that the arrival of Philip Nolan and his horse trading activities was actually a cover for scouting the 1 and and its defenses for the United States Army. Their suspicions continued to grow over the next years as filibustering activities increased in frequency and were often accompanied by local uprisings in the name of independence. The nucleus of many of these revolts centered around the activities of Father Miguel Hidalgo in 1810. Support for Hidalgo in Texas the following year was led by Juan Bautista de 1 as Casas. While Las Casas enjoyed a brief success, he was soon overthrown and executed (Institute of Texan Cultures 1971:6). If the Spanish authorities thought, however, that this would end the desire for independence in Texas, then they were badly mistaken. In 1812, an expedition was 1 aunched from Louisiana of American filibusters and Mexican revolutionaries. They were successful in taking San Antonio and established it as their capital in the first independent state of the new Republic of the North. The new republic was crushed the next year, however, when a 1 arge Spanish force soundly defeated the republican army at the Battle of the Medina. Among the conquering army was a young 1 ieutenant named Santa Anna 
(Myers 1948:101), who observed the "proper" treatment of rebels. It remained in his mind when he returned to San Antonio almost a quarter of a century 1ater.

While independence from Spain came in 1821, after the royalist army joined the rebe1s, there would still be many $10 \mathrm{ca} 1$ revolts and insurrections over the succeeding years. It seems as if "independence" can have many different meanings for different people. The first clash in Texas against the Republic of Mexico came at Anahuac in 1832, when a group of colonists 1 aid siege to the Mexican garrison. The clash was solved in this instance by the government removing the source of the problem, the $10 \mathrm{cal}$ commander; but clearly these Anglo colonists would bear watching in the future. Likewise, the Texians began to re-evaluate the situation. While they had first supported President Santa Anna in his rise to power; their pleas for separate statehood guaranteed in the Constitution of 1824 had gone unheeded. When Stephen F. Austin attempted to deliver their petitions, he was imprisoned. Talk soon began among some factions to no longer press for a separate statehood in a Mexican union, but to take up arms for complete independence (Institute of Texan Cultures 1975:11).

General Santa Anna had other things on his mind in 1835 than the wishes of some colonists in the most distant of the Mexican states. He had a revolt much closer to home to deal with in the State of Zacatecas. His army was now becoming quite experienced at putting down these 1 ocal rebelions. The political struggle between Centralists, favoring a strong national government, and Federalists; who supported stronger state rights, was growing in Coahuila and Texas, with the Federalists having the 1 argest number of supporters. When the governor attempted to move his office from Saltillo to San Antonio without Central approval, he was arrested (Sanchez Lamego 1968:8). Santa Anna thought that it should be sufficient to dispatch his brother-in-1aw, General Cos, to que 11 any future disturbances. Disturbances did occur, however, at Gonzales and Goliad. The spark of the Texas revolution had grown to a ful 1 blown flame by the end of October, and cos found himself trapped in San Antonio and under siege. In addition to the army of Texian colonists, there was a growing number of volunteers from the United States to bolster the attacking forces. After close hand-to-hand fighting in the streets of San Antonio, Cos surrendered on December 11, 1835. He and his troops were paroled to return below the Rio Grande. Behind they left 21 pieces of artillery, about 500 muskets, their fortifications, and the beginning of a legend.

\section{Artillery Projectiles}

There has long been a question of the number and size of the Mexican artill lery employed during the seige of the Alamo in 1836. Carlos Sanchez Navarro (1960:83) stated that the artillery consisted of "cañon de 8, uno de 6 y un obus de 7 p." "Obus" translates as a howitzer or howitzer shel1, while "p." is an abbreviation for pulgada. One Mexican pulgada of the period is equal to 0.916 th of an inch. Seven pulgadas would then be the equivalent of 6.412 inches. Travis, in his letter of March 3 to the convention at Washington-on-the-Brazos, stated that he had been under bombardment "from two howitzers; one a five and a half inch, the other an eight inch and a heavy 
cannonade from two long nine-pounders" (Tink 1e 1958:113). Travis also stated that the wal $1 \mathrm{~s}$ were fortified as proof against cannon balls, and that at least 200 shells had fallen within their works without losing a single man (ibid.).

The most common piece of field artillery in use during the early 19th century was the smoothbore gun, or cannon, which could have either a bronze or iron tube. The size of the bore was measured in pounds, which was roughly the weight of an iron ball fired from that size tube. Guns had a rather flat trajectory, and their range was 1 imited by their caliber. During this period, most were intended for firing solid shot (Gooding 1965), although some guns were 1 ater developed for firing bursting shel1s. The principal use of iron solid shot was in battering down the walls of buildings or fortifications. Smoothbore guns were also capable of firing grapeshot and canister rounds. While shot was directed at buildings, these 1 ast two rounds were intended only for the destruction of personnel. They have a shorter range than shot and were used mostly against massed troops. Grapeshot is the 1 arger bal1 and was stacked inside a 1 inen bag and tied with cord. The quilted appearance was similar to a cluster of grapes; thus the name. Canister was similar, but consisted of smaller balls packed between sawdust and placed inside a tin canister. When fired, both containers came apart and scattered their deadly contents, much as a 1 arge shotgun blast (Mckee and Mason 1980).

The howitzer was an improvement over the smoothbore gun in that it had a much higher trajectory and was able to fire up and over any obstacle to place the round on target, which was usually enemy personne1. The howitzer she11, or bomb, was of bronze and was hol $10 w$. This was so that a powder charge and fuse might be placed in the shell and timed for the shell to burst over the target. This was accomplished by a paper and powder fuse placed inside a wooden adapter plug (Bartleson 1972:136). Before firing, the gunner cut the fuse for the desired number of minutes till ignition, then he drove the plug into the fuse hole. When the howitzer was fired, the fuse was ignited and the powder charge exploded, scattering the bronze she11 fragments. Sometimes the lead musket balls were also placed inside the shell with the powder to act as shrapne1, which had just come into use (ibid.).

\section{Small Arms Ammunition}

The most common relic recovered from most 19th-century battlefield sites is the small arms round. The familiar elongated bullet had not yet appeared on the scene in 1836, and the on 1 y small arms projectile to be seen was the round lead bal1. The shape and appearance were all similar, regardless of whether the ball was fired in a musket, rifle, carbine, or pistol. The only distinguishing feature was the size, or caliber, of the ball to fit the arm in use. For standard infantry use, the musket bal1 was frequently prewrapped with the appropriate powder charge in a paper cartridge. This eliminated the need for the soldier to measure out the prescribed charge of black powder in the heat of battle and greatly sped up the time of loading. Jose de la Peña wrote that when the First Brigade of the Mexican army left for Texas they brought with them "one hundred boxes of gun cartridges and one thousand flintstones" (Perry, translator and editor 1975:15). There can be no doubt 
that paper cartridges were widely used during the battle of the Alamo, as Santa Anna stated in his general order for March 5 that grenadiers and scouts received four cartridges with two flints in reserve (Sanchez Lamego 1968:33). De 1 a Peña said members of the reserves and select companies carried seven rounds apiece. There must have been a large number of cartridges fired during the battle. De 1 a Peña estimated the total number of cartridges used at around 50,000 (Perry, translator and editor 1975:51).

In addition to prewrapped paper cartridges, artifacts recovered from the site indicate that additional lead balls were also cast on location in the field. This may have been to supplement the existing supply of infantry cartridges. In this case, they would have been wrapped using measured bulk powder and pieces of scrap paper. There is also the possibility that the balls were for artillery use, and were added to the powder chambers of howitzer shells to act as shrapne1. In any event, there were numerous bal1s available, and in the idle hours perhaps some of them were converted to other uses (Mckee and Mason 1980).

\section{Firearms Parts}

As the final smoke cleared on the battlefields of Europe, the victory of the British over the French became quite evident. This was due in no smal1 measure to the firearms that had built the British empire. White there was stil1 a great deal of respect for the valor and discipline of the French soldier in military circles, the al 1 ied powers would not al low France to rearm for many years. Belgium had a reputation for the manufacture of fine arms, but after Water 100 much of the country 1 ay in ruins. The same could be said of Spain. Therefore, in the 1820s, any smal1 country that was trying to resupply its military forces would naturally turn to Britain as its source of arms. The Napoleanic Wars had left Britain with a tremendous national debt, and the recent unfortunate disagreement with the young United States had not helped much. There was also a large amount of French war supplies that had been captured and should be disposed of, not to mention the recent experiments with the percussion system that might soon render the flintlock obsolete. Yes, Britain would certainly have some arms for sale to her friends!

The new Republic of Mexico found itself in a serious state by the early 1830s. The army had been rebuilt after the wars for independence, but the armament situation was becoming critical. The few Spanish muskets that remained of those captured in 1821 were in poor condition and bad1y worn. The hope was that the national arms factory which had produced muskets and pistols in Mexico before independence could be reopened, but that was not to be. The machinery still existed, but replacement of parts was difficult, and they could not be maintained ( $N$ ieto, Brown, and Hefter 1958:53). There was still some money in the national treasury for an emergency, and indications were that one was near. Negotiations were opened with representatives of the British Crown, and a deal was soon struck.

In 1833, the British Board of Ordnance had 440,000 India Pattern Brown Bess muskets on hand (Fig. 16). However, the India Pattern musket was no 1 onger the standard service arm in Britain, but had been replaced by the New Land 


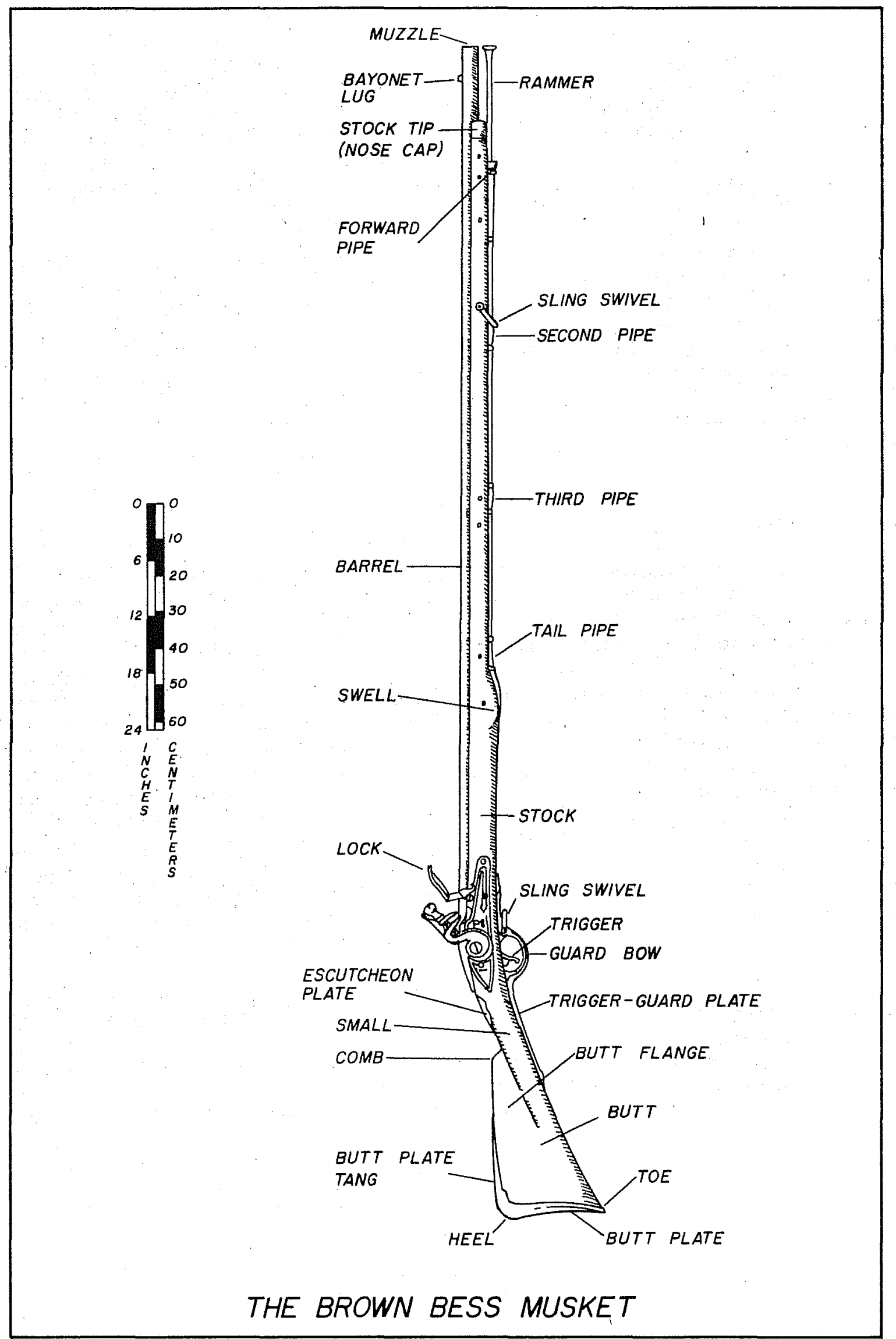

Figure 16. Diagram of the Brown Bess Musket Detailing the Location of its Parts. Adapted from Neumann (1967:1). 
Service musket. It is, therefore, 1ikely that Britain chose to sel 1 the India Pattern Brown Bess to Mexico (Koury 1973:8). This was the main musket that was purchased for the common soldier. The best English rifle in service at the time was the Baker, which had a rifled bore instead of the smoothbore of the musket. This gave it a greater range and accuracy than any other firearm in use by the Mexican army. It al so had a higher price. Nevertheless, Baker rifles were purchased for the preferred companies of cazadores and granaderos (James 1983:91) of the 1 ine battalions. Baker carbines and Tower pistols were even purchased for the cavalry troops.

\section{Edged Weapons}

Not long after the musket became available, the bayonet was invented. The plug bayonets were in use into the 18th century. They were little more than a dagger with a 1 arge wooden handle that fit into the muzzle of a musket. The obvious disadvantage to this arrangement was that the musket could not be fired while the bayonet was in place. The plug bayonet was also only held in the muzzle by friction and had a habit of coming loose at the wrong moments. This was solved by placing a bayonet on a socket that locked around the barrel (Fig. 17). In order for the soldier to still be able to sight the musket and clear the ramrod with the bayonet attached, the blade, which was triangular in cross section, was placed to the right side.

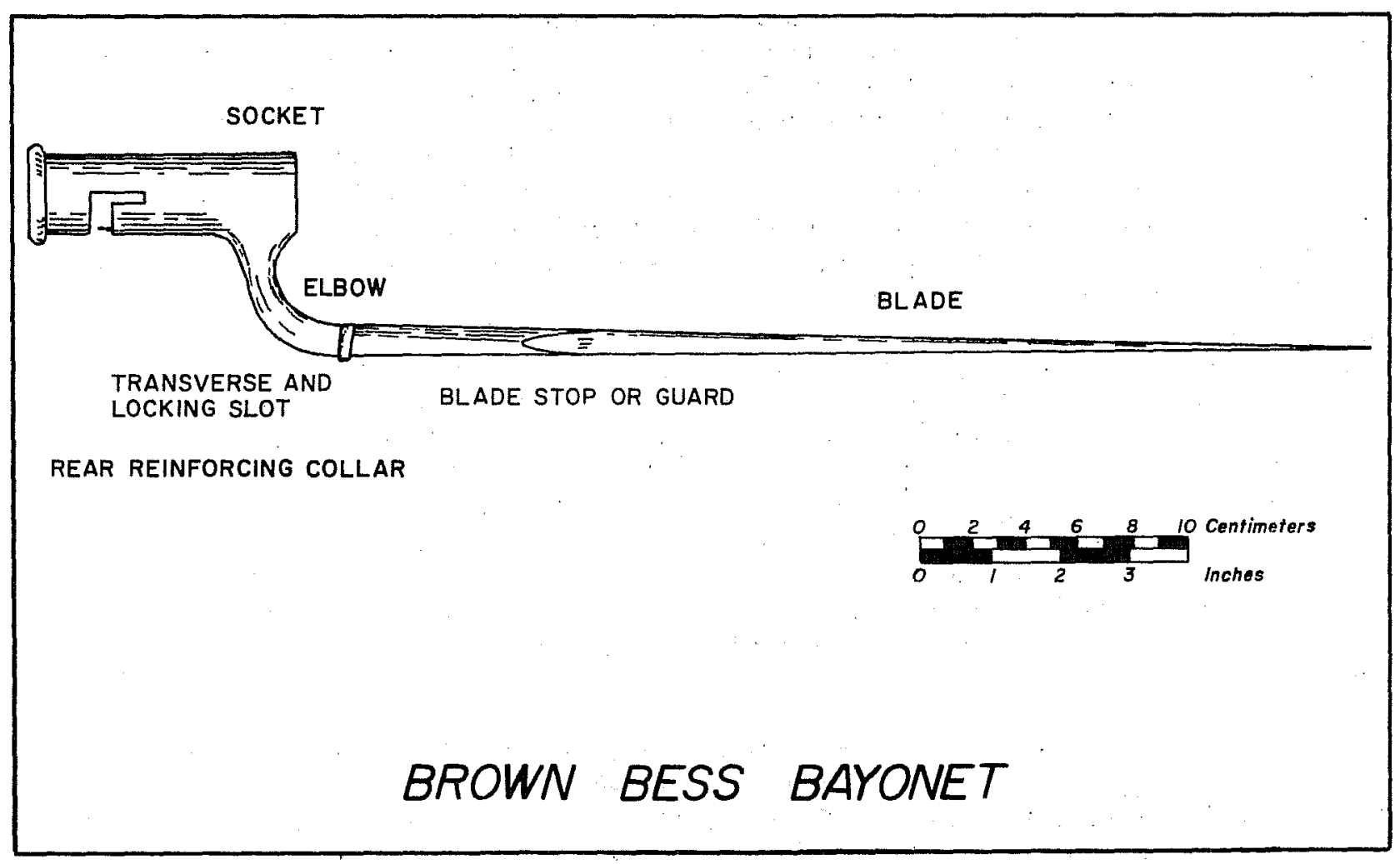

Figure 17. Diagram of a Brown Bess Bayonet. 
When the Mexican army bought British muskets and rifles in the early 1830s, they also bought the accompanying bayonets. As valuable as firepower. was, they knew that the bayonet would be the principal weapon for hand-to-hand fighting. It was for this reason that Santa Anna included in his general order for March 5, the phrase "al1 armaments wil1 be in good shape-especial1y the bayonets" (Sanchez Lamego 1968:33).

In addition to bayonets, the Mexican soldier also brought a number of swords with him. General Nicolas Bravo stated that the mounted artillery company of his Texas field force was issued sabers with steel scabbards (Nieto, Brown, and Hefter 1958:53). Sabers were a 1 so issued to the cavalry troops, while foot soldiers, militia, and sergeants a11 had different patterns of swords (see Fig. 18). Even the members of the band had a special pattern sword. There were probably also older pattern swords still in use from the Spanish colonial days. Inevitably, the common soldier brought his al1-purpose belt knife, which was worn under the tunic. This was a civil rather than a mi 1 itary weapon and was relied upon for many of the daily camp chores, as well as personal defense.

\section{Horse Equipment}

While the ordinary Mexican soldier walked to Texas, plenty of 1 ivestock were also on the expedition. The heavy supplies were transported in carts pulled by oxen, while pack mules hauled the lighter supplies. Mules were also used in the transportation of artillery (Perry, trans lator and editor 1975 ). Horses, which were used by the cavalry, artillery, and senior officers, were the most valuable transportation means and in greatest demand. Their ranks had been severely depleted by adverse weather conditions and difficulties of the march. Insufficient grain had been packed as they believed they could forage along the road and be "fed with what serves as beds to the horseman" (ibid.:13). This shortage rendered many of the horses useless, and replacements had to be located.

The cavalry corps was supposed to be provided the best horses available but this was sometimes easier said than done. Upon arriving at Bejar, a surprise vanguard with 60 horsemen was sent into the city. Officers were ordered to yield their own horses to the dragoons who lacked good mounts in order to bring the detail up to strength (Perry, translator and editor 1975:57). While cavalry troops did not play an active role during the assault of the Alamo on March 6 , Santa Anna did instruct them in his general order to "occupy the Alameda" and to be saddled by three o'clock in the morning. Their duty was "to guard the camp and keep anyone from deserting" (Sanchez Lamego 1968:33).

In March, the spring grasses had not yet appeared due to the cold weather. If there were not enough mounts to keep a 1 arge remuda, then grass would have to be cut to supplement their meager supply of oats. The horses also had to be shod, and the horse equipment needed care. The Mexican cavalry saddles consisted of a wooden frame held by iron plates, covered with leather, and stuffed with horsehair (Nieto, Brown, and Hefter 1958:56). It was also hung with 1 ightweight iron stirrups. Horseshoes were either 1 ight or heavy, depending upon the duties and service of the animal. The horseshoes were 


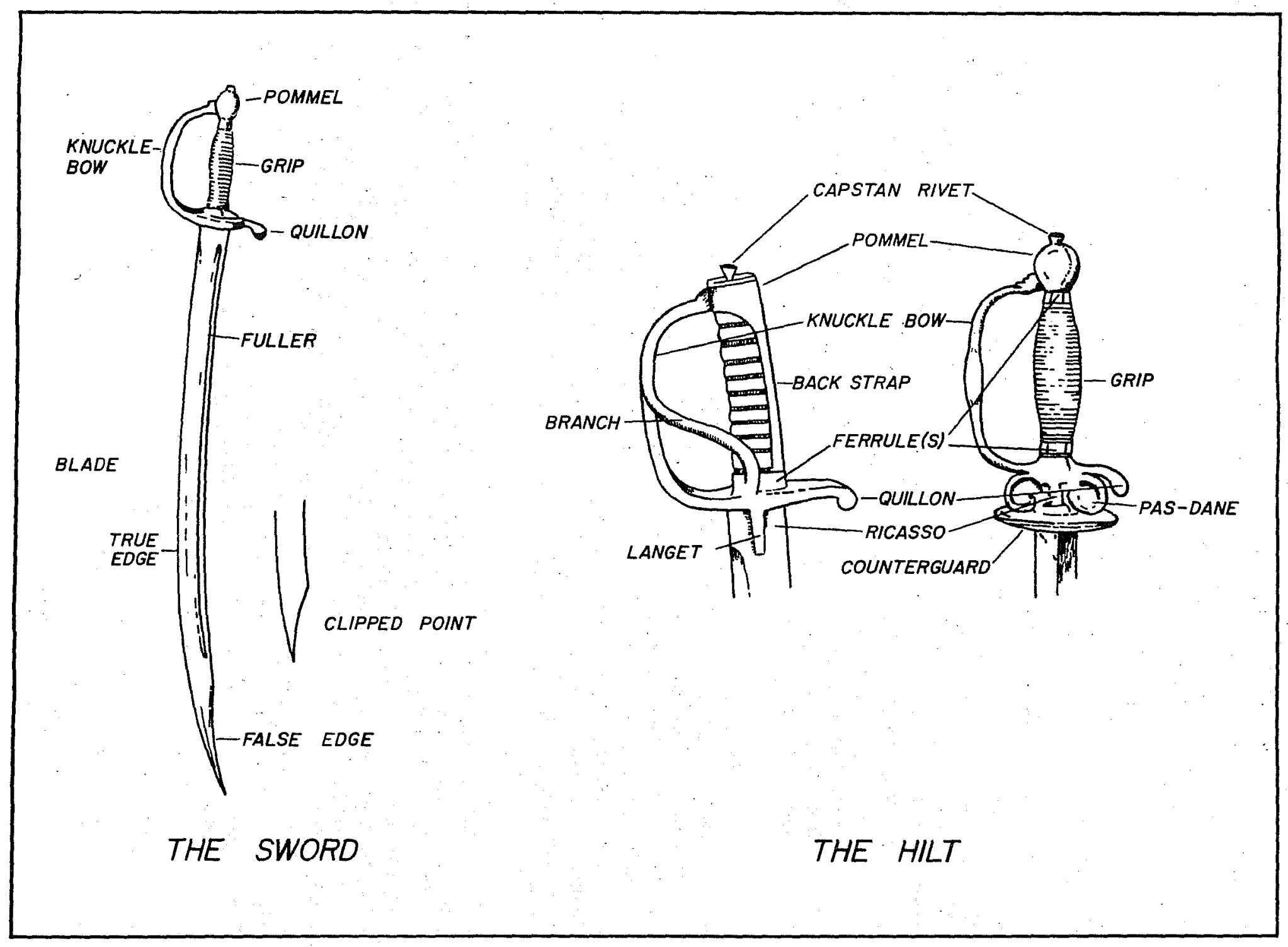

ईे

Figure 18. Nomenclature of a Sword and Hi7t. Adapted from Neumann (1967:1). 
individual 1 y made by a farrier with a traveling forge, and the rear shoes were made with a projection on the toe that was absent on those made for the front hooves (Fig. 19). There were usually four nail holes to the outside of each shoe, while there were only three to the inside (ibid.:Plate II). Most of the bits in use by the cavalry were either curb or pelham bits, while there were probably some Spanish ring bits in use through civil sources.

\section{Personal Items}

The 1 ife of a Mexican soldier in the field must have been a very hard one. He was often conscripted into the army for a 10-year period, or volunteered for eight years of service because of dire economic conditions. For this he was paid between 15 and 20 pesos a month, not counting the numerous deductions for supplies and services for which he was billed. There was very 1 ittle in the way of medical assistance that could be expected, as he was dependent upon only the medical facilities in the area that were available. It was because of the difficult medical conditions on the Texas campaign that a Military Health Corps was established in August 1836 (Nieto, Brown, and Hefter 1958:58).

In addition to his musket, an ordinary infantryman would be issued the following items: a barracks cap; three shirts; a tailcoat tunic of Queretaro cloth; two canvas fatigue jackets; three pair of pants, one each of dress, regular issue, and fatigue canvas; a black neck cravat; a pair of shoes; a leather shako with cords and ornaments; an overcoat; a blanket with carrier; a leather and canvas pack with straps; a tool set; a wooden barrel canteen with strap; a leather crossbelt and cartridge box with tin insert; a leather crossbelt and frog to hold the bayonet and scabbard; a haversack; and a towe 1 (ibid.:52).

The Mexican uniform had taken on a distinctly French 100 after 1803, when Spain as a French al 1 y had introduced the new style to her North American colony. The French influence had been retained after independence, and would remain so for the next 50 years (Hefter 1968:60). The first Mexican uniforms issued may have been from French imports and were reflected in the dress regulations of 1821, 1823, and 1827. By 1831, the Mexican government was requesting bids on the Dress Contract of 1832. It specified for infantry a taflcoat of dark blue with a scarlet collar, 1 ape 1 s, and cuffs, al 1 with white piping. The lapels formed a double-breasted plastron front, with two rows of six gold-plated brass buttons (Fig. 20). The following year, the design was modified to the dress regulations of 1833 , which changed the pattern of the tunic to a single-breasted dark blue coatee with red collar, cuffs, and piping. It had seven buttons down the front and three smal1er ones on a red bar decorating each cuff. Apparently both the 1832 contract and the 1833 regulation dress continued to be used together unti1 1839, when each regiment in the Mexican army received its own distinctive uniform (Nieto, Brown, and Hefter 1958:52). 


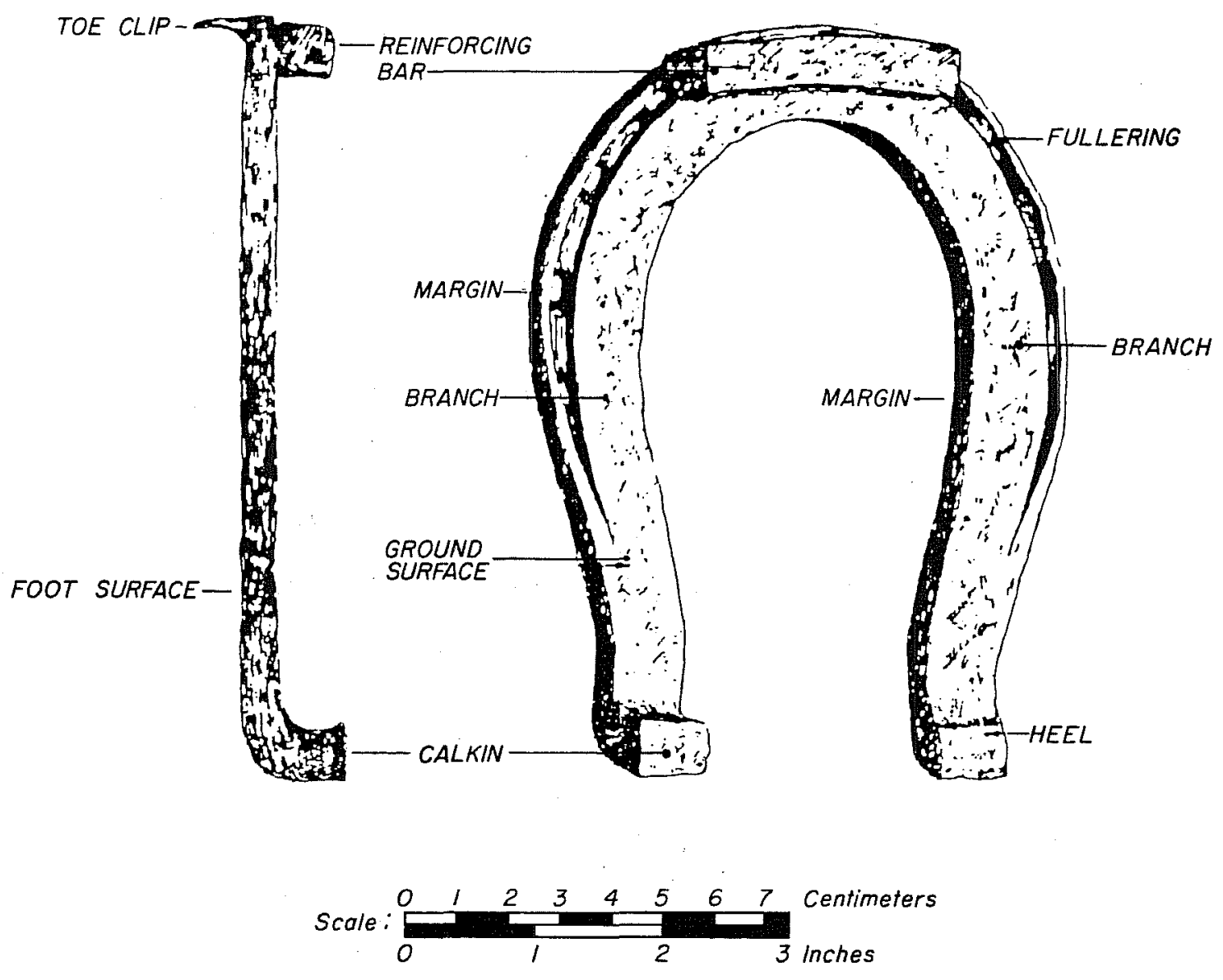

PARTS OF THE HORSESHOE

Figure 19. Diagram of a 19th-Century Horseshoe. Adapted from Noë 1 Hume (1973:109). 


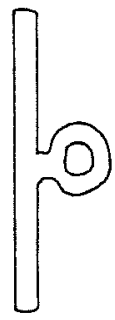

ONE PIECE CAST

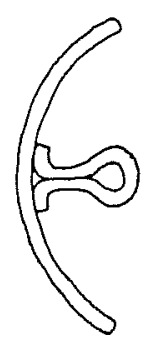

TWO PIECE CONVEX

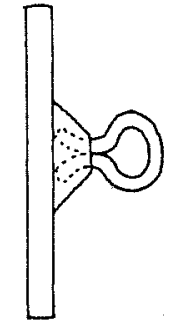

CAST WITH SEPARATE SHANK

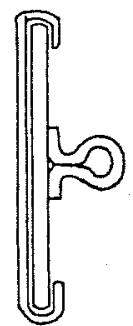

TWO PIECE

FACED

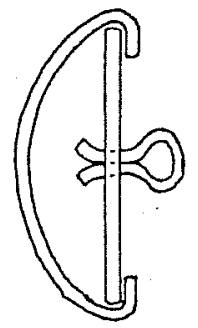

THREE PIECE
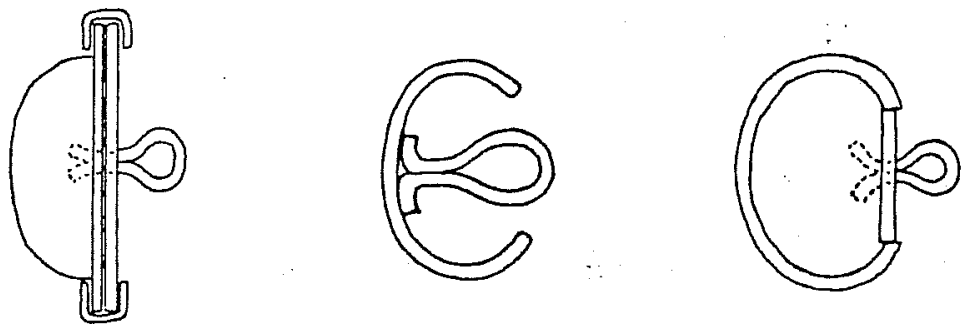

"BULlet" BUTtTon

FOUR PIECE. (TWO PIECE)

"BULLET" BUTtoN

(THREE PIECE)

\section{BUTTON TYPES}

Figure 20. 19th-Century Military Button Types. Adapted from Wyckoff (1984: xix). 


\section{DESCRIPTION OF THE MILITARY ARTIFACTS}

The classification and analysis of the military artifacts were conducted at the 1 aboratory facilities of the Center for Archaeological Research located on the campus of The University of Texas at San Antonio. The artifacts were washed, catalogued, and separated for analysis by Lynn Highley, Fairmont Project laboratory director. The initial cleaning of the items was 1 imited to soap and water and the painstaking removal of dirt and dried mud. No chemical cleaners or solvents have been used on these artifacts to date.

The current state of preservation for these materials ranges from excellent (items constructed from brass, bronze, copper, and 1ead) to very poor (items of iron). The bulk of the badly oxidized items are made of iron and are heavily encrusted with rust.

In the discussion that follows, individual artifacts are described. Identifying catalogue numbers are abbreviated. For example, a catalogue number of J-6 indicates the item was recovered from Unit J, Level 6 (main datum). Letter designators refer to specific excavation units or discrete collection areas (e.g., A, B, C, or EM, EMX, EMEX). The relative locations of excavation units and collection areas can be found on Figure 2. The artifacts presented in this section represent a portion of the items that were recognizable given their current state of preservation. A program of chemical cleaning, combined with $X$-ray analysis, would undoubted $1 y$ result in the identification of additional artifacts which were manufactured for and functioned in a strictiy military capacity.

\section{Howitzer Shelle Intact}

Provenience: D-8/9 (Fig. 21,d)

Recovered from the excavations was a bronze she 11 that weighs $10.65 \mathrm{~kg}$, and has a diameter from 17.3 to $17.5 \mathrm{~cm}$, or about 6.75 inches. The fuse opening is $1.9 \mathrm{~cm}$ in diameter, and the she 11 casing is $1.5 \mathrm{~cm}$ thick at that point. There is a 1 ight green patina on the bronze surface and a $5-\mathrm{cm}$ iron oxide discoloration spot on one side, where it was in contact with an iron solid shot. It was first thought that the shell was for an 8-inch howitzer, with a 1 arge amount of windage. This was due to a letter written by Travis (1836) and the fact that the 8-inch howitzer was one of the most common sizes in use during the 1 ate 18th and early 19th centuries. Additional research now shows it 1 ikely, however, that the she 11 may be for a 7-inch howitzer, which

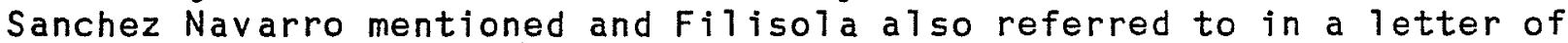
January 23, 1836 (Santos 1968). If so, the piece would be equivalent to a 42-pounder, a very unusual size, and may possibly indicate a Spanish or early Mexican origin. 

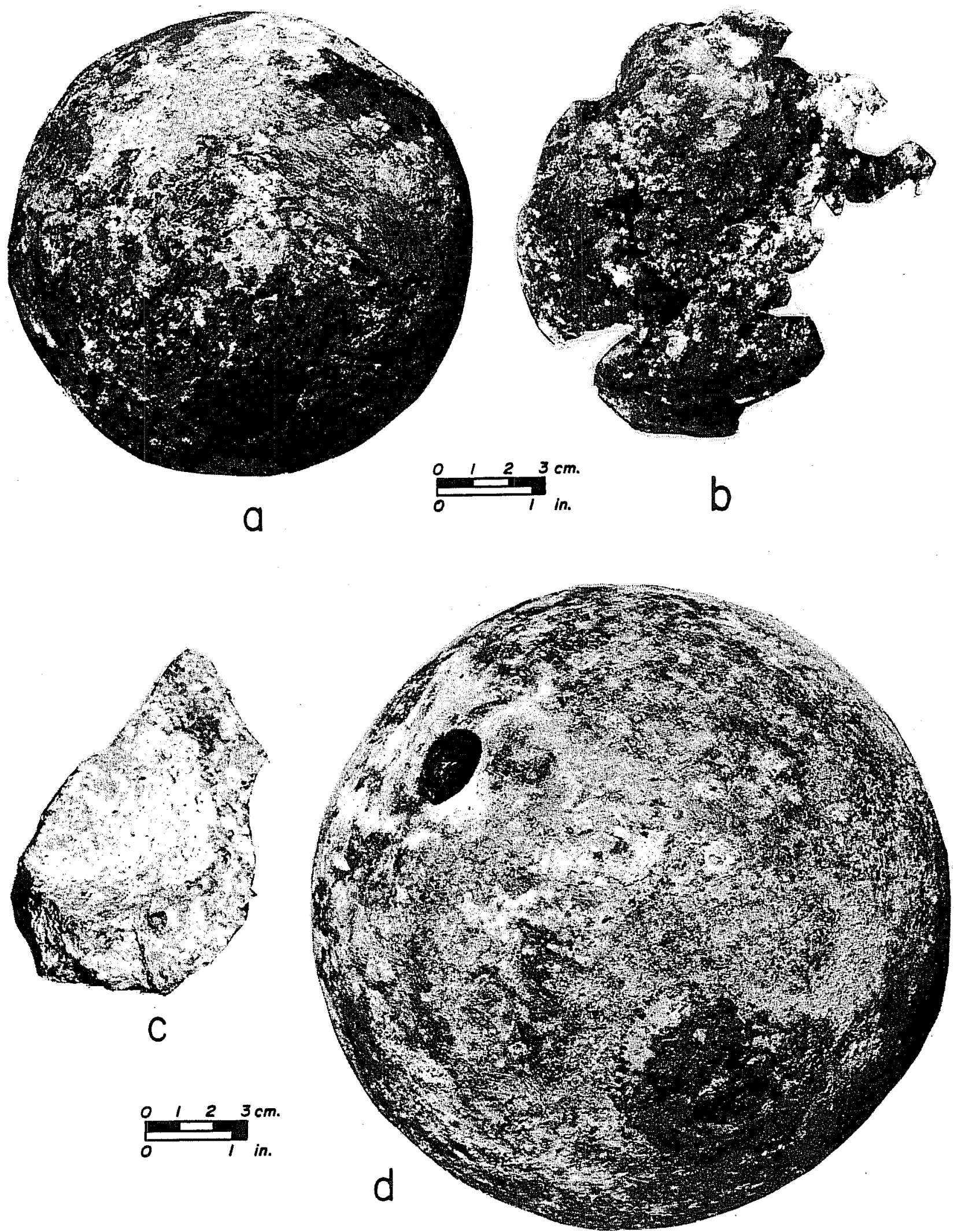

Figure 21. Cannonballs. a, iron solid shot cannonball for a 9-pound cannon; b. fragment of a solid shot cannonbal1, probably for a 6-pound cannon; c, fragment of a bronze 7-inch howitzer she11; d, unfired and intact 7-inch bronze howitzer shell. 


\section{Howitzer Shell, Eragment}

\section{Provenience: $M-2$ (Fig. $21, \mathrm{C}$ )}

A bronze exploded fragment weighs $604 \mathrm{~g}$. It is irregular in shape, approximately $10.5 \mathrm{~cm}$ 1 ong, $6.3 \mathrm{~cm}$ wide, and has an average thickness of $2 \mathrm{~cm}$. As the Texans had no howitzers in their armament, it may be assumed that it is from a similar shell as that recovered from $D-8 / 9$. It is a 150 worth noting that the same type bronze she 11 fragments were recovered in 1977 during archaeological excavations along the palisade wall in front of the A 1 amo Chape 1 (Eaton 1980:25). It is interesting to note that this 1ocation was one of the areas that would have been under fire from a howitzer battery in the area of La Villita.

\section{Solid Shot Cannonball, Intact}

Provenience: C-8 (Fig. $21, a)$

An iron solid shot bal1, which weighs $5 \mathrm{~kg}$ and is $10.9 \mathrm{~cm}$ in diameter, corresponds to the size for a 9-pounder (Ripley 1970), and matches Travis' description of the Mexican artillery as "long nine-pounders." Some of the Mexican sources place their largest guns as 8-pounders, and De 1 a Peña stated that they were 12-pounders (Perry, trans1ator and editor 1975:15). There is also the possibility that the solid shot could have been an incoming round from the Texans, as Travis (1836) stated in a letter to the convention on March 3, that he needed "200 rounds of six, nine, twelve and eighteen-pound bal1s" for his cannon (Lord 1961:141).

\section{Solid Shote Eragment}

\section{Provenience: D-8 (Fig. 2l,b)}

The fragment is the remains of an iron solid shot, badly deteriorated due to a chemical reaction with the bronze howitzer she11 (D-8/9), next to which it was found. The remaining weight is $1.2 \mathrm{~kg}$ and appears to have an approximate diameter of $10.4 \mathrm{~cm}$. While much of the remaining surface is covered with heavy oxidation, the original size appears to have been much smaller, possibly for a 6-pounder.

\section{Grapeshot}

Provenience: $\mathrm{J}-4, \mathrm{M}-8, \mathrm{Y}-5$ ( $\mathrm{Fig} .22, \mathrm{t}, \mathrm{u}, \mathrm{v}$ )

The artifact from $\mathrm{J}-4$ appears to be of 1 ead, weighs $168.5 \mathrm{~g}$, and is $3.4 \mathrm{~cm}$ in diameter. The specimen from $M-8$ is a 1 so of 1 ead, weighs $167.9 \mathrm{~g}$, and has a diameter of $3.35 \mathrm{~cm}$. The grapeshot from $Y-5$ has the green oxidation characteristic of bronze, and the remains of some vegetable fiber are stil1 adhering to it (Fig. $22, \mathrm{t}$ ). It weighs $146.8 \mathrm{~g}$ and is $3.3 \mathrm{~cm}$ in diameter. 


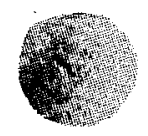

$a$
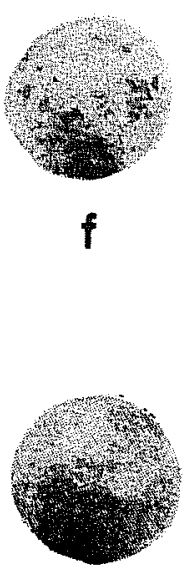

k

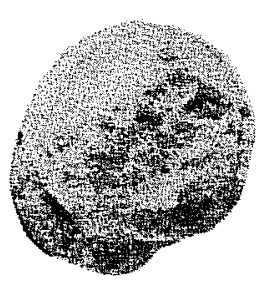

p

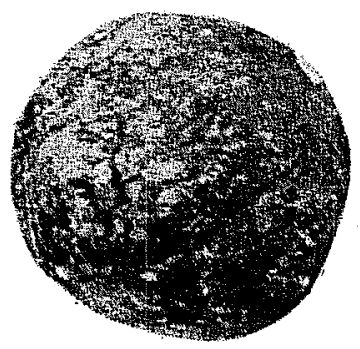

$\uparrow$

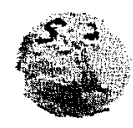

b

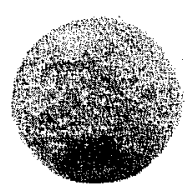

$\mathbf{g}$

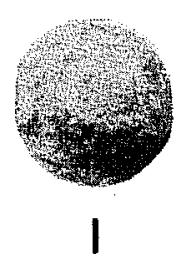

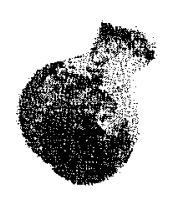

C

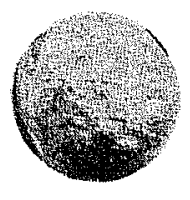

h

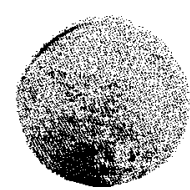

m

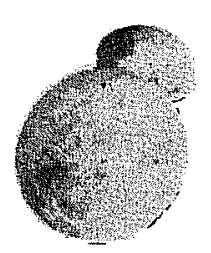

d
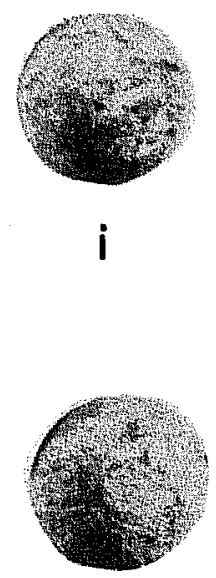

n

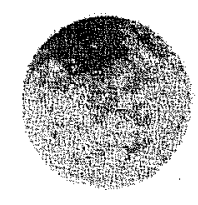

e
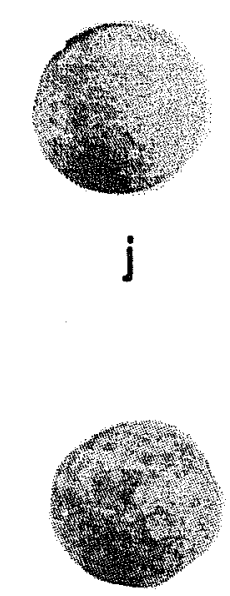

0
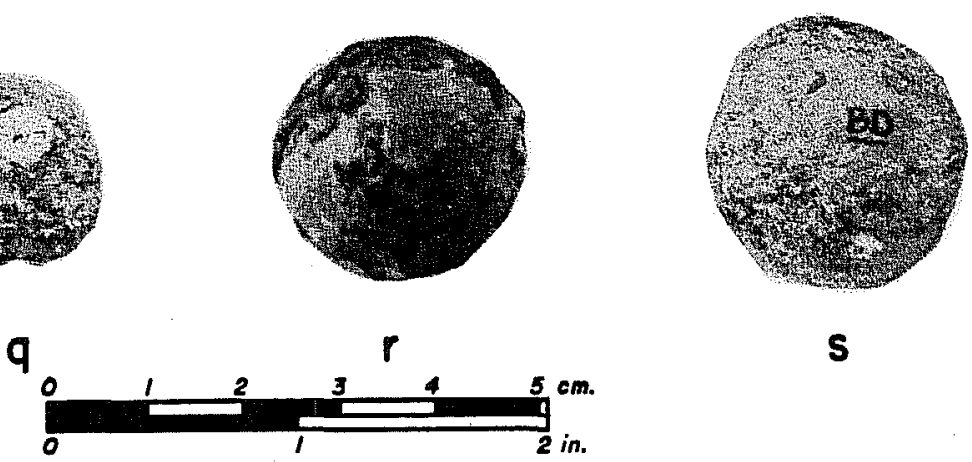

S

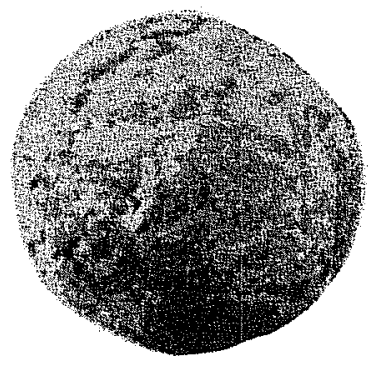

u

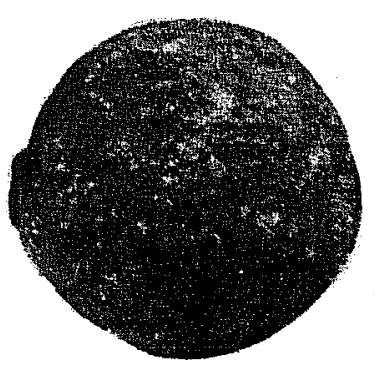

v

Figure 22. Lead Bal1s. a, .48 caliber lead ba11; b, .44 caltber lead bal1; c, poorly cast .49 caliber lead ball with casting sprue still attached; d, .69 caliber lead bal1 with casting sprue still attached; e-0, .69 caliber lead bal $1 \mathrm{~s}$ with no evidence of firing; $p$, lead canister shot distorted by firing; $q$, fragment of a lead canister shot; $r$, badly oxidized bronze canister shot; s, lead canister shot; $t, v$, lead grapeshot; u, bronze grapeshot. 


\section{Canister}

Provenience: $B D, M-7, F-3, E M-3$ (Fig. 22,p-s)

The lead ball from $B D$ weighs $73 \mathrm{~g}$ and is $2.65 \mathrm{~cm}$ in diameter (Fig. 22,s). The 1 ead ba 11 from $M-7$ has a heavy green oxidation, general 1 y associated with bronze. It weighs $64.9 \mathrm{~g}$ and is $2.5 \mathrm{~cm}$ in diameter ( $F$ ig. $22, \mathrm{r}$ ). The bal1 from $F-3$ is of lead, but badly distorted and $f l$ attened on one side due to impact (Fig. 22,p). It weighs $57 \mathrm{~g}$ and is $2.3 \mathrm{~cm}$ in diameter. The fragment from EM-3 is about $25 \%$ of a 1 ead ba 11 which has been fractured ( $F$ ig. $22, q$ ). It weighs $18.5 \mathrm{~g}$ and is approximately $2.1 \mathrm{~cm}$ across. It is quite 1 ikely that the lead balis from $\mathrm{F}-3$ and $E M-3$ may represent incoming rounds, or battlefield pick-ups, that were deposited in the ditch at a 1 ater date. It appears that most of the canister and grapeshot are from 9 and 12-pounders.

\section{Musket Balls}

Provenience: $F-3(2), F-2, M-6(2), B-5(2), I-1(2), I-2, B-3, P-3, L-3$, $I-4(2), U-6, L-5(3), L-6(2), K-B A L K[1-6](2), X-1, X-3, F-S U R F A C E[\# 1-4](4)$, $\mathrm{J}-6, \mathrm{~F}-4, \mathrm{M}-7(2), \mathrm{BD}(\mathrm{Fig}, 22, \mathrm{~d}-0)$

Thirty-four lead balls of approximately .69 caliber were found in 21 different units and levels at this site. Seventeen of the balls are similar in appearance, of excellent casting, and show no seams or indications of firing. These may be assumed to be arsenal castings and were transported to the site. Their weight ranges from 26.2 to $33.5 \mathrm{~g}$, with the average about $29.4 \mathrm{~g}$. Their size ranges from 1.65 to $1.8 \mathrm{~cm}$, with the average size about $1.75 \mathrm{~cm}$. Nine of the balls show evidence of casting seams to varying degrees, and one $(L-5)$ still has the casting sprue attached (Fig $22, d)$. The sprue is the lead stem left after casting a ball in a mold and was intended to be cut off before the ball could be fired. The pronounced seams indicate these balls were cast in a worn bullet mold where the sides did not meet properly. That and the remaining sprue would indicate that they were cast in the field, probably nearby. Two of the lead bal1s (I-4) have portions of oxidized iron fragments still adhering to their surfaces. Two other balls (L-BALK [1-6] and $P-3$ ) have faceted dents on their surfaces which may indicate their use as camp marbles (Calver and Bolton 1950:78), or may simply be concussion spots from having been improperly carried in a cartridge box. One bal1 (L-BALK [1-6]) has numerous cuts on the surface, as if hacked with a sharp instrument. Six of the balls (B-5, F-3, F-4, I-1, L-5, X-3) show evidence of impact on firing, to various degrees. They, 1 ike the other .69 caliber balls previously discussed, were intended for use in a .75 caliber Brown Bess musket (ibid.:80), the principal infantry weapon used by the Mexican soldier and by many of the Texans. The difference in the size of the bal1 and the musket bore can be due to windage, the clearance to compensate for the fou 1 ing of powder residue and the varying of the bore by different musket contractors. 
Rifle or Pistol Balls

Provenience: $\quad L-4, T-1, C-5$ (Fig. $22, a-c)$

Three small lead balls were found. One (L-4; Fig. 22,C) still has the sprue attached. The casting seam is evident, and the two halves do not match. It was obviously cast in a single-cavity pliers type mold, which was badly worn. On inspecting the bullet, the owner decided the miscasting was too great to use, and the bal1 was discarded. The bal1 from L-4 weighs $11 \mathrm{~g}$ and has a diameter of $1.3 \mathrm{~cm}$, or $.49 \mathrm{cal}$ iber. The sprue is $0.5 \mathrm{~cm}$ 1ong and $0.7 \mathrm{~cm}$ in diameter. The bal1 from T-1 weighs $10.3 \mathrm{~g}$ and has a diameter of $1.25 \mathrm{~cm}$, or .48 caliber (Fig. 22,a). On inspection, there is a flattened band around the circumference of the bal1, indicating it was rammed tightly into a rifle barrel with a thin patch. It also shows traces of eight rifle grooves around the band and a corresponding area of impact on the other side. It was possibly fired from a Kentucky rifle. The ball from $\mathrm{C}-5$ weighs $6.35 \mathrm{~g}$ and is $1.15 \mathrm{~cm}$ in diameter, or $.44 \mathrm{cal}$ iber ( $F$ ig. $22, \mathrm{~b}$ ). It al so appears to be an incoming rifle round, and there is considerable damage to the surface.

\section{Gunflints}

Provenience: $E M-4, U-2-10(2), F-4, E M-5$, SURFACE, $X-2, I-1, M-4, E M-3, C-5$, $\mathrm{D}-6(2), \mathrm{BDF}, \mathrm{M}-4, \mathrm{~J}-3$ (Fig. $23, \mathrm{a}-1$ )

Sixteen unifacially worked gunflints were found, of varying size and degree of workmanship. Many are broken and incomplete. The majority appear to be of 1ocal origin and manufacture. They vary in size from the 1 argest of $3.6 \times$ $3 \mathrm{~cm}$, to the smallest of $2.1 \times 1.7 \mathrm{~cm}$. They generally fit into one of the three major classifications (musket, rifle, and pistol flints), based upon size. Four flints, one each from EM-4, U-2-10 (Fig. 23,h), F-4 (Fig. 23, 1), and EM-5 ( $F i g .23, k$ ), conform to the size for musket flints. Eight flints, one each from SURFACE (Fig. 23,f), U-2-10, X-2 (Fig. 23,g), I-1 (Fig. 23,j), $M-4$ (Fig. 23,e), EM-3 (Fig. 23,i), C-5, and D-6 (Fig. 23,b), match the size of rifle flints. Four flints, one each from J-3 (Fig. 23,c), BDF, M-4, and D-6, conform to the size of pistol flints (Peterson 1968:63). One of the pistol flints $(D-6)$ is a golden honey color, which is generally associated with French-made gunflints (Fig. 23,a).

\section{Gunflint Pads}

Provenience: $\mathrm{J}-7, \mathrm{~J}-3, \mathrm{C}-5, \mathrm{C}-3, \mathrm{M}-6$ (Fig. 23,m-p)

Five lead ovals were recovered, which may have been used to wrap around the bases of gunflints in order that the cap and jaw of a flintlock hammer might get a more secure grip on them. This would necessitate that the oval be bent in the middle as it was wrapped, accounting for the halves that were found. The specimen from $\mathrm{J}-7$ is $4 \times 5.75 \mathrm{~cm}$, with a portion of it missing (Fig. 23,p). The specimen from J-3 is $2.9 \times 3.25 \mathrm{~cm}$, and is incomplete (Fig. $23, n)$. The specimen from $\mathrm{C}-5$ is represented by only half, and is $3.5 \mathrm{~cm}$ wide $\times 3.1 \mathrm{~cm}$ long (Fig. 23,0 ). The pad from $\mathrm{C}-3$ is a perfectly 


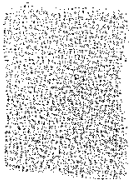

a

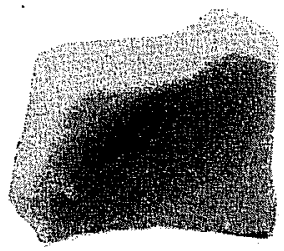

e

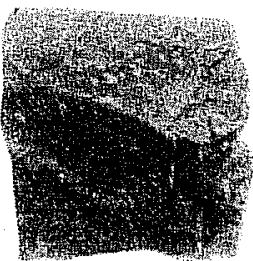

i

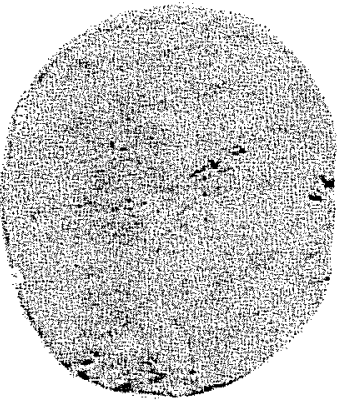

m

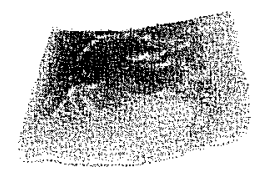

b

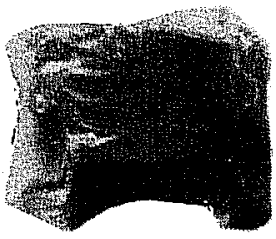

f
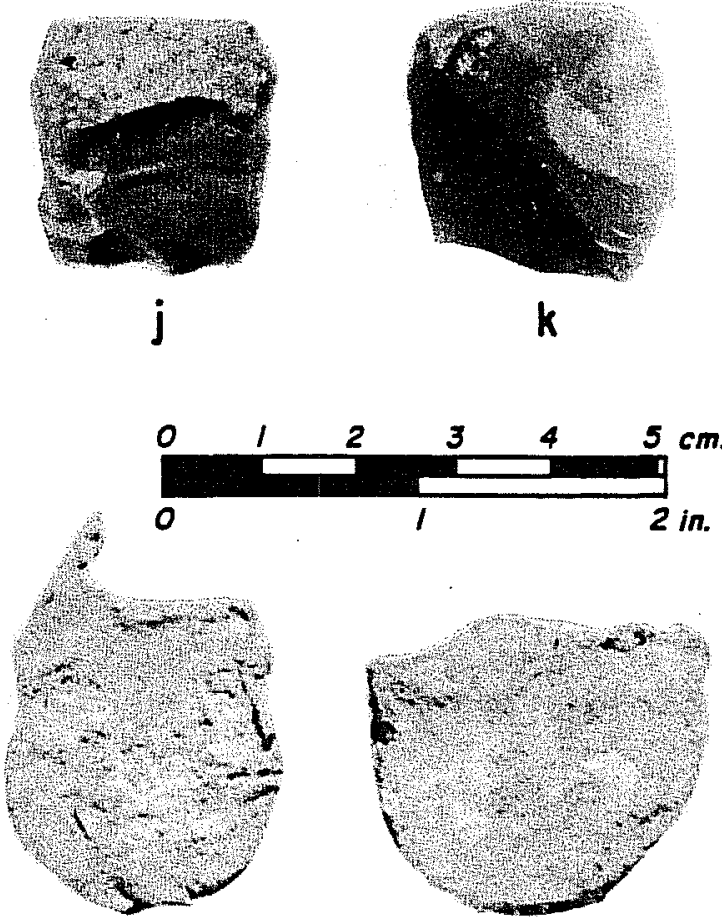

n

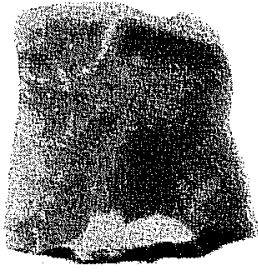

g

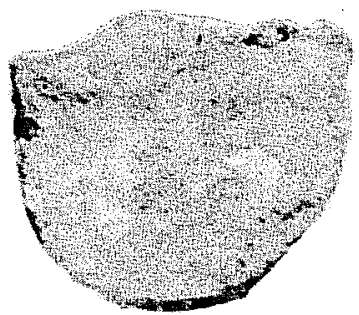

0

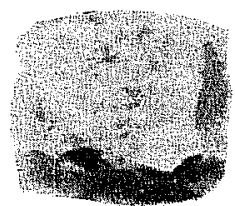

d

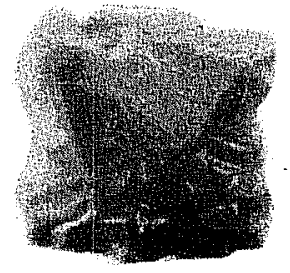

h

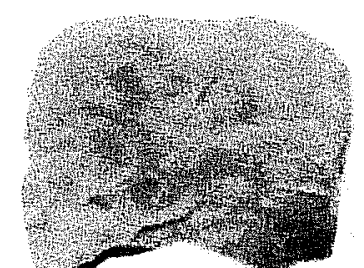

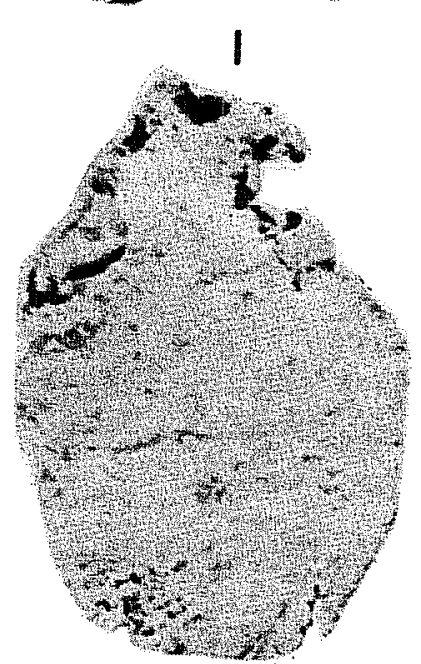

p

Figure 23. Gunflints and Lead Pads. a, French-made, honey-colored chert pistol flint; b, rifle flint; c, British-made, gray-colored pistol flint; d,e,g,i,j, rifle flint; f, British-made, gray-colored rifle flint; $h, k, 1, n$, musket flint; m, musket flint pad or hem weight; o, half musket flint pad; p, possible rifle flint pad. 
formed oval and is $3.5 \mathrm{~cm}$ wide $\times 4 \mathrm{~cm}$ 1ong (Fig. 23,m). Al1 of the pads are the right size for musket flints, except the specimen from $\mathrm{J}-3$, which was possibly for a rifle. It is also possible, however, that the specimen from C-3 may have been used as a cloak or uniform weight to hold a hem down (Wi 1 bur 1969:25).

\section{Barrel. Rifle}

\section{Provenience: S/EM VILLITA FILL (Not Pictured)}

A round iron rifle barrel, heavily encrusted with oxidation weighs $2 \mathrm{~kg}$ and is $77.5 \mathrm{~cm}$ in length. The bore diameter at the muzzle is heavily oxidized, but appears to be about $1.55 \mathrm{~cm}$, or about a $.61 \mathrm{cal}$ iber. The barrel diameter is slightly tapering and appears to be $2.4 \mathrm{~cm}$ at the muzzle and $3.15 \mathrm{~cm}$ near the breechplug. The lug on the breechplug is $2.3 \mathrm{~cm} \times 0.95 \mathrm{~cm}$. Near the muzzle is a 1.9-cm-long blade front sight, and $19 \mathrm{~cm}$ from the breech is the remains of a two-leaf rear sight. There are two loops beneath the barre1, the first, which appears to be a barrel $1 \mathrm{ug}$ for a wedge, is $5.5 \mathrm{~cm}$ from the muzzle. A second larger loop appears to be for a sling swivel and is $9.85 \mathrm{~cm}$ from the muzzle. There are no indications of a drum or nipple for percussion ignition, so it is assumed that the barrel is for a flintlock and that the touchhole is covered with oxidation, which is heavy throughout the barrel. It is likely that the barrel is for a First Pattern Baker Rifle. It should have two more barrel loops, a tang strap, and a bayonet 1 ug which was brazed to the right side near the muzzle (James 1983:91), all of which are missing. It conforms, however, to the .62 caliber specified for the Baker (Meuse 1965:10), if the heavy oxidation is considered. Most models had a 30-inchlong barre1, but this varied among contractors; and a 30.5-inch barrel is not unknown (Miller 1978:135).

\section{Possible Barrel_Eragment}

Provenience: R-LEVEL UNKNOWN (Not Pictured)

A possible barrel fragment is represented by a round iron tube, open on both ends. It is heavily oxidized, but appears to be about $12 \mathrm{~cm}$ long and $2.65 \mathrm{~cm}$ in diameter. Bore diameter is approximately $1.65 \mathrm{~cm}$, or about a $.65 \mathrm{ca} 1$ iber.

\section{Lock Plate and Hammer Eragment}

Provenience: BD (Not Pictured)

An iron flintlock lock plate and a portion of an iron priming pan were recovered from the backdirt. The lock plate weighs $85.5 \mathrm{~g}$ and is $8.9 \mathrm{~cm}$ long, although the proximal and distal ends are missing. If they were present, it is estimated the lock plate would be $11.5 \mathrm{~cm} 1$ ong overall. Inside the lock plate, there are remains of the tumbler, bridle, sear, and sear spring, but in a heavily oxidized condition. On the outside of the lock plate, the lower portion of the hammer remains attached, but in a very poor condition. As a separate piece, also recovered from the backdirt, was the 
remains of the upper portion of the flintlock hammer, including the spur, cap, and screw. Figure 24 provides a schematic diagram of the relative location of these pieces on a Brown Bess 1 ock plate. This portion weighs $27 \mathrm{~g}$ and is $4.35 \times 3.5 \mathrm{~cm}$. The neck is completely missing, so it is impossible to say if it had an early gooseneck or the reinforced hammer that appeared after 1809. The size would indicate the lock plate and hammer are for a pistol or smal1 rifle, possibly a Baker.

\section{Erizzen}

Provenience: B-6 (Fig. 25,e)

An iron frizzen for a flintlock weighs $30.5 \mathrm{~g}$ and is $4.1 \mathrm{~cm} \mathrm{high} \times 3.3 \mathrm{~cm}$ 1ong, with a striking area $2.3 \mathrm{~cm}$ wide. It is somewhat unusual on this specimen that the distal bar is straight instead of curved and is $1.8 \mathrm{~cm}$ long. The size would indicate the frizzen is for a pistol or smal1 rifle (Kirk 1 and 1984).

\section{Erizzen Spring}

Provenience: B-4 (Fig. 25,h)

An iron spring to keep the frizzen closed weighs $25.75 \mathrm{~g}$ and is $6 \mathrm{~cm} \times$ $1.5 \mathrm{~cm}$. One side of it attaches to the outer portion of a 1ock plate. It is the size general1y associated with a musket, possibly one variation of an India Pattern Brown Bess.

\section{Butt Plate}

Provenience: E-4 (Fig. $30, a$ )

A brass butt $p$ late weighs $200 \mathrm{~g}$ and is $12.5 \mathrm{~cm}$ long $\times 5.2 \mathrm{~cm}$ wide, with a 9-cm-long tang. The tang has two steps and a 1 ug to hold a pin. Two recessed screw holes are in the butt. The butt $p l a t e$ has been identified as coming from an India Pattern Brown Bess musket (Darling 1970:51).

\section{Pistol Butt Cap and Strap}

\section{Provenience: BD (Fig. $25, i$ )}

Recovered from the backdirt was a brass oval domed butt cap, with a portion of the backstrap. The cap is cast and has a single incised 1 ine around the perimeter, with a raised external collar for the butt screw. Weight is $46.5 \mathrm{~g}$, and the cap is $2.85 \mathrm{~cm}$ wide and $3.7 \mathrm{~cm}$ 1 ong. The backstrap is one piece and with the cap is $7.8 \mathrm{~cm}$ 10ng. It tapers in width from $2.45 \mathrm{~cm}$ to $1.35 \mathrm{~cm}$, al though the upper portion of the strap is damaged. While the style is not one of the standard issue military pistols of the period, it does date from the early 19th century and appears to be one of the gentlemen's traveling pistols sometimes carried by officers. 


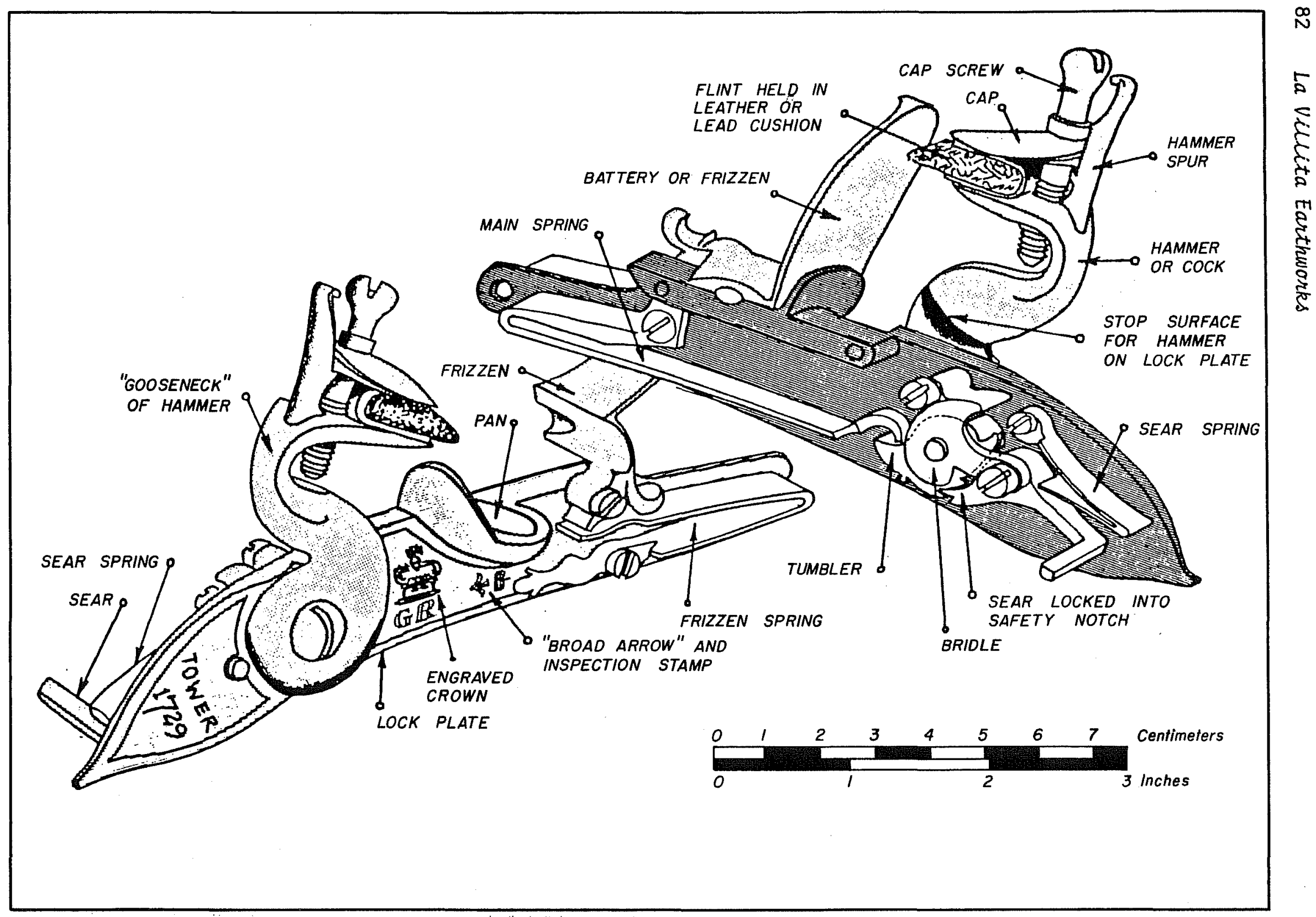

Figure 24. Schematic Diagram of the Lock Plate for a Brown Bess Flintlock Musket. Adapted from Butler (1971:22). 


\section{Irigger Guard Strap}

Provenience: $B D(F i g .25, g)$

A cast brass strap is the rear portion of a musket's trigger guard. It weighs $30.05 \mathrm{~g}$ and is $10 \mathrm{~cm}$ long and $1.4 \mathrm{~cm}$ wide. There were two recessed screw holes present, although only a portion of one hole remains. This strap was part of a trigger guard from an India Pattern Brown Bess musket (Peterson 1968:28).

\section{Irigger Guard, Fragment}

Provenience: FINAL BULLDOZING (Fig. 25,f)

A thick fragment of a cast brass trigger guard weighs $39.5 \mathrm{~g}$, is $0.75 \mathrm{~cm}$ thick, $3.7 \mathrm{~cm}$ long, and $2.9 \mathrm{~cm}$ wide. It appears to be a portion of the forward part of a Baker Rifle trigger guard (Myatt 1979:30).

\section{Irigger Plates}

Provenience: U-12, F-3 (Fig. 25,a,C)

Two oval brass $p$ lates with rectangular openings to go around a trigger were recovered. The $p 1$ ate recovered from U-12 weighs $15.5 \mathrm{~g}$, is $6 \mathrm{~cm} 7 \mathrm{ong}$, and $1.5 \mathrm{~cm}$ wide. There is a single internal collar for the barrel screw on the forward part $0.4 \mathrm{~cm}$ high. On the inside, near the trigger opening, are four incised marks (Fig. 25,a). The plate from $F-3$ weighs $10.7 \mathrm{~g}$ and is $5.75 \mathrm{~cm}$ long and $1.55 \mathrm{~cm}$ wide. It has a $0.6 \mathrm{~cm}$ screw coll lar and two incised marks on the inside (Fig. $25, \mathrm{C}$ ). The purpose of the incised marks is unknown, but it was probably used by the arsenal to match up parts for a particular weapon. The size of the plates indicates they would be for a pistol or small rifle.

\section{Thimble Ramrod Pipe}

Provenience: $B D(F i g .25, b)$

A badiy crushed brass ramrod pipe weighs $13 \mathrm{~g}$ and is $3.85 \mathrm{~cm}$ long. It has a single incised line at each end and a single pin hole along the central edge. It is bel ieved to be the second or third ramrod pipe for a Short Land Pattern (Type 1) Brown Bess musket (Darling 1970:51).

\section{Pratt's Improved Ramred Pipe}

Provenience: BD (Fig. 25,d)

A cast brass ramrod pipe with bell mouth, ridge, and coll ar from the backdirt a 7 so has the one-piece 1 ug for a barrel pin. It weighs $16 \mathrm{~g}$ and is $4.5 \mathrm{~cm}$ long. The bell mouth is $1.3 \mathrm{~cm}$ in diameter, and the other end is $1 \mathrm{~cm}$. The object is a second or third ramrod pipe for a Brown Bess musket. This 
Figure 25. Musket Hardware.

a, brass trigger plate from a pistol or smal1 rifle;

b, second or third brass ramrod pipe believed to be from a British-made Short Land Pattern (Type 1) Brown Bess musket;

c, brass trigger plate from a pistol or small rifle;

d, Pratt's Improved Ramrod Pipe made of brass for a Brown Bess musket;

e, iron frizzen for a flintlock pistol or small rifle;

$f$, cast brass trigger guard fragment from the forward part of a Baker Rifle trigger guard;

g. forward portion of a cast brass strap from the trigger guard on an India Pattern Brown Bess musket;

$h$, iron frizzen spring from an India Pattern Brown Bess musket;

$i$, early 19th-century brass pistol butt cap and strap. 
(8)

a

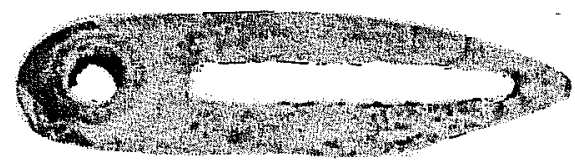

C

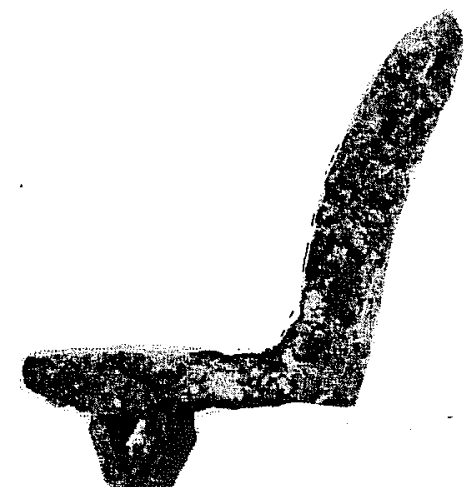

e
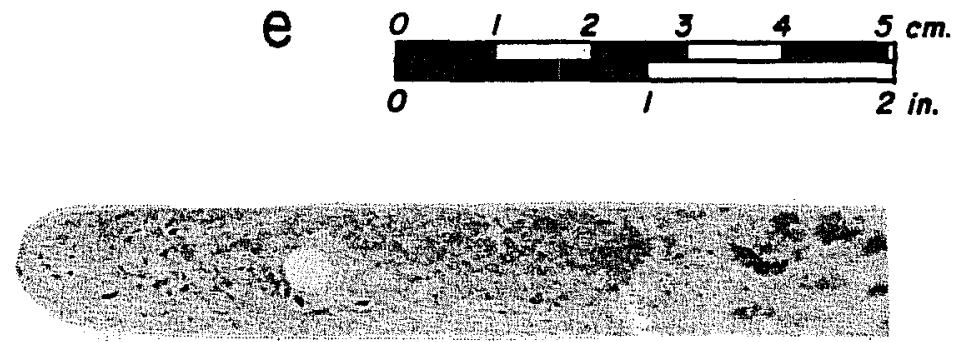

g

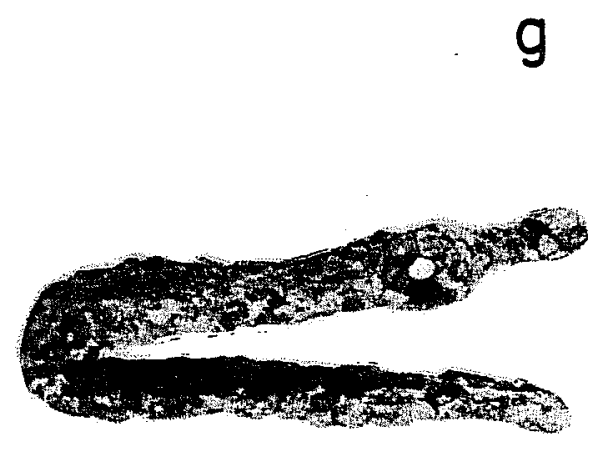

h

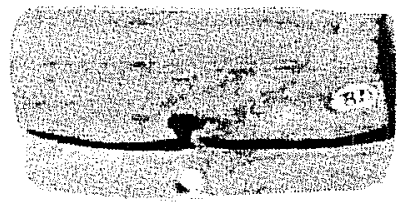

b

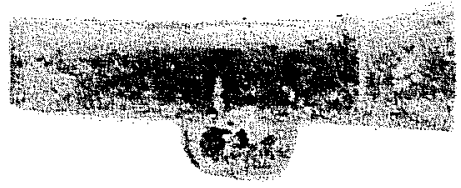

d

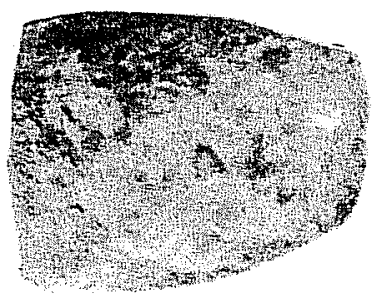

f

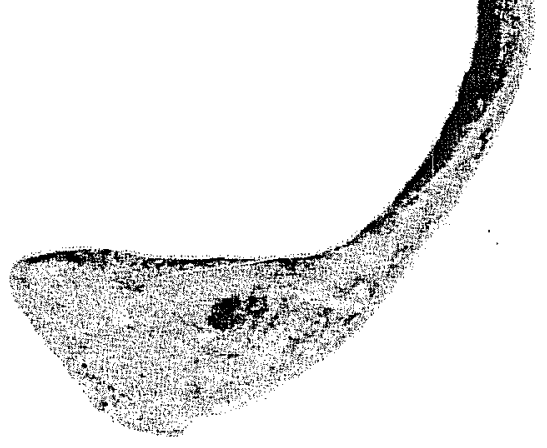


variation was developed by London gunmaker John Pratt in 1777 and gradually rep 1 aced the older type thimble pipe. The Pratt's improvement was used in the 1 ater Short Land, New Pattern muskets, and a 11 India Pattern muskets (Darling 1970:39).

\section{Sword Guard}

\section{Provenience: B-6 (Fig. 26,C)}

An iron two-branch sword hilt weighs $252.1 \mathrm{~g}$. It is $20 \mathrm{~cm}$ long from the quili on to the rear of the knuck le bow, and $11 \mathrm{~cm}$ wide from the edge of the second branch of the counterguard. The guard has a short, flat quilion that is $2.9 \mathrm{~cm}$ and a $\mathrm{fl}$ at knuck $1 \mathrm{e}$ bow $1.7 \mathrm{~cm}$ wide, of which the rear portion is missing. The second branch of the guard is intact and is $14.5 \mathrm{~cm}$ in 1 ength and $1.5 \mathrm{~cm}$ wide. The first branch is only partially intact and is $11 \mathrm{~cm}$ long and $1.5 \mathrm{~cm}$ wide. There is a $2.7 \mathrm{~cm}$ opening between the first and second branches, and an equal amount between the first branch and the knuck le bow. The counterguard is partially missing, but is $8.85 \mathrm{~cm}$ long. The opening in the guard for the blade tang is $1.6 \mathrm{~cm}$ long and $0.45 \mathrm{~cm}$ wide. The two-branch sword hilt, in both iron and brass, was becoming a very popular type in the early 19th century. It appeared in many forms, both with and without 1 angets. A similar type from the early 1830 s was carried by Francisco Ruiz during his Mexican army service (Institute of Texan Cultures exhibit). Many hilts were imported to Mexico from Germany and England, and there rebiaded (Brinckerhoff and Chamberlain 1972:87). The guard that most conforms to this specimen, however, is the British model 1821 Light Cavalry and Arti 11 ery sword (Robson 1975:29). It is likely that it could have had the 1829 modification to the backstrap (Wilkinson-Latham 1971:21), but that portion is now missing.

\section{Possible Srord Blade Fragments}

Provenience: $\quad J-5, M-6$ (Fig. $27, c, d$ )

Both specimens are in very poor condition and heavily oxidized. They may be fragments of sword blades, based upon their cross sections, or merely pieces of iron strapping. It is impossible to tel 1 without $X$-ray analysis. The sword blade from $\mathrm{J}-5$ is in six pieces, which were found together, and rough $1 \mathrm{y}$ correspond to each other (Fig. $27, d)$. They weigh $83.75 \mathrm{~g}$ and, placed end to end, are $25.5 \mathrm{~cm}$ long $\times 2.5 \mathrm{~cm}$ wide. From the shape and tapering cross section, it would appear to be a single-edged blade, as carried by the majority of field troops. The blade from $M-6$ is in three pieces and weighs $40 \mathrm{~g}$ (Fig. $27, \mathrm{C}$ ). It is $20 \mathrm{~cm}$ in 1 ength and $1.5 \mathrm{~cm}$ wide. The blade appears to gradually taper and is of the double-edged type carried by general staff, militia, and cadet officers. 

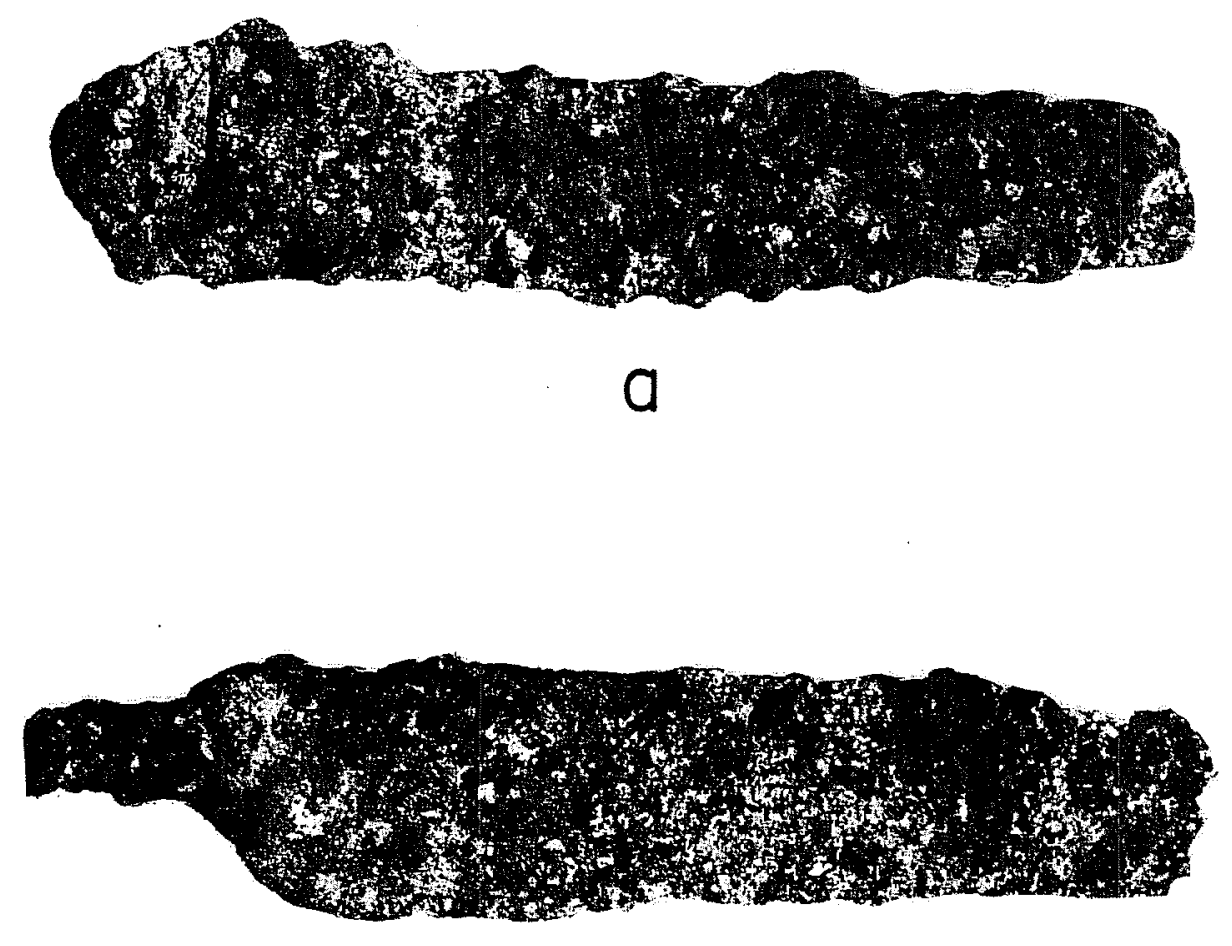

b

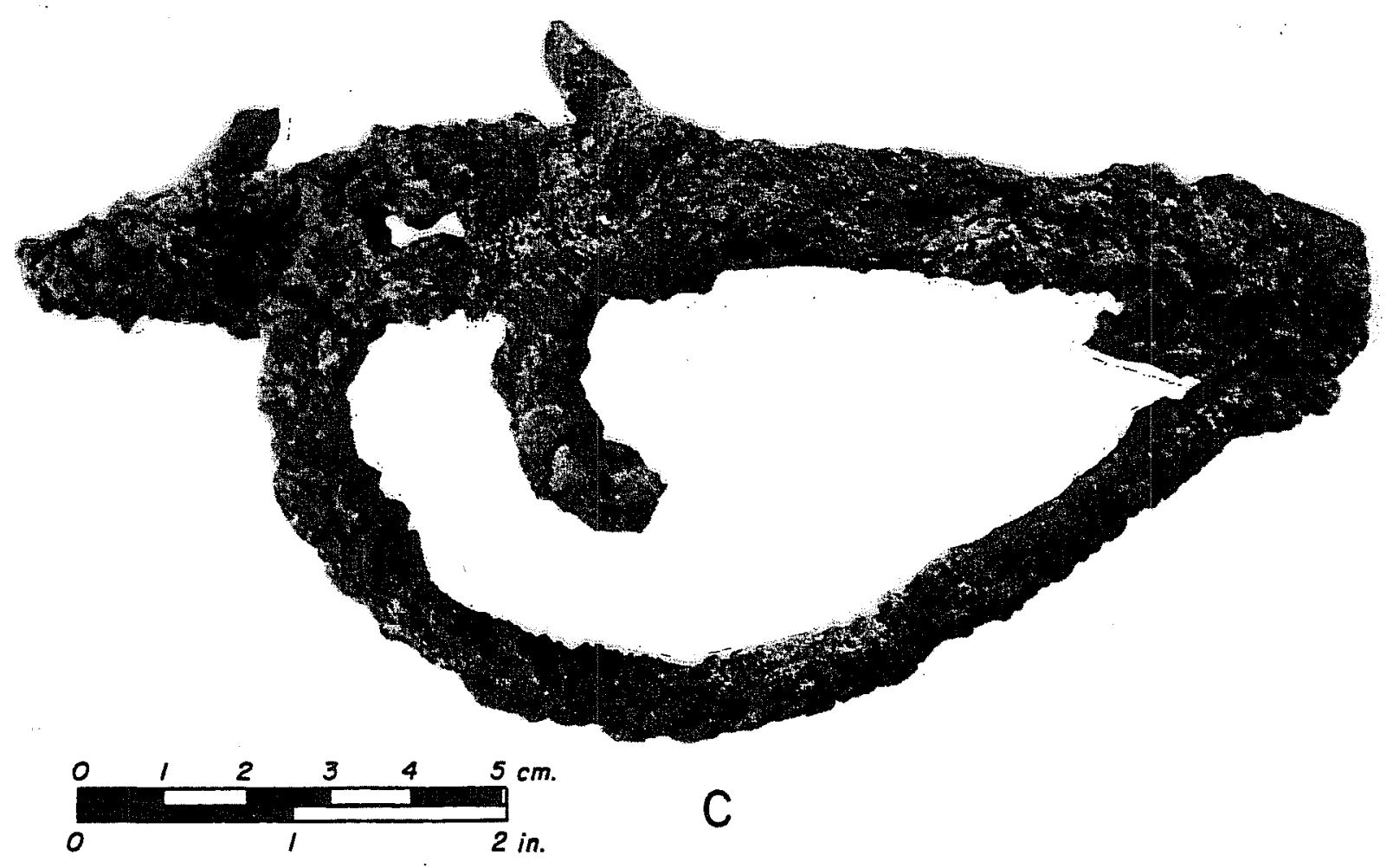

Figure 26. Knife Blades and Sword Guard. a, bad1y oxidized iron knife blade fragment believed to be from a late 18th-/early 19th-century Mexican belt knife; b, badly oxidized iron knife and tang believed to be from a Mexican belt knife; c, iron two-branch sword hilt from a British 1821 model Light Cavalry and Artillery sword. 
Figure 27. Knife B1ades and Possible Sword Blades.

a, badly oxidized iron knife blade fragment believed to be from a Mexican belt knife;

b, badly oxidized iron knife blade fragment believed to be from a Mexican belt knife;

c, badly oxidized fragments which conform to the specifications for a double-edged sword b 1 ade of 1 ate 18th-/early 19th-century manufacture;

d, badly oxidized iron fragments which conform to specifications for a single-edged sword blade. 

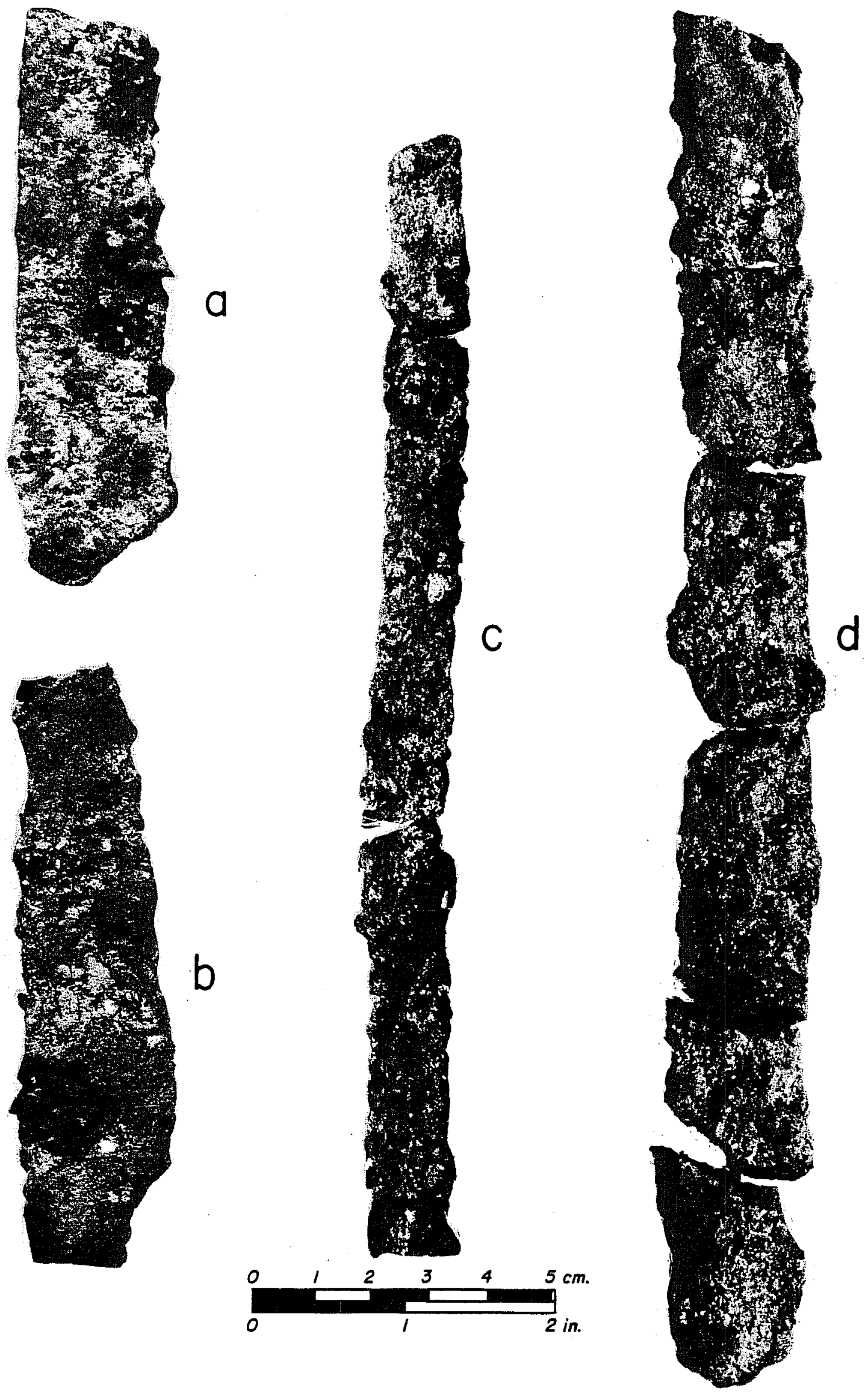


\section{Bayonets, Broyn Bess}

Provenience: J-4, L-PARAPET FILL, and EM-3 (Fig. 28,a,b)

Al 1 three bayonets are iron with triangular blades and are in varying degrees of completeness. The specimen recovered from J-4 has all of the socket and most of the blade intact, except for the tip. It weighs $445 \mathrm{~g}$ and is $47 \mathrm{~cm}$ in overal1 length ( $F$ ig. $28, \mathrm{~b}$ ). The socket is $19.45 \mathrm{~cm}$ long and has a diameter of $3.6 \mathrm{~cm}$ at the col 1ar and $3 \mathrm{~cm}$ at the muzzle. The neck is $3.5 \mathrm{~cm}$, and the blade is $3.15 \mathrm{~cm}$ wide at the shank and $35 \mathrm{~cm}$ long. The bayonet from the L-PARAPET FILL has only the blade present, which weighs $252 \mathrm{~g}$ and is $3.3 \mathrm{~cm}$ wide $\times 42.4 \mathrm{~cm}$ long, of which $1.4 \mathrm{~cm}$ appears to be part of the shank (Fig. 28,a). The fragment from EM-3 is on 1 y the tip of a bayonet; it weighs $46 \mathrm{~g}$ and is $2 \mathrm{~cm}$ wide $\times 11.9 \mathrm{~cm}$ long (not pictured). On the 1 arge proximal end there are the remains of cloth fragments preserved in the oxidation. While it is impossible to determine which pattern of Brown Bess musket the bayonets were made for, they appear to be the later type and were 1 ikely for the India Pattern musket (Webster 1964:14).

\section{Pike Head or Bayonet}

\section{Provenience: U-9 (Fig. $28, \mathrm{C}$ )}

An iron triangular-shaped b 1 ade with a straight tang weighs $230.5 \mathrm{~g}$ and is $45.5 \mathrm{~cm}$ in overal1 length. The blade is $3 \mathrm{~cm}$ wide, with rounded shoulders in the French style, and is $35.5 \mathrm{~cm}$ 1ong. The tang is $10 \mathrm{~cm}$ long, and it is impossible to tell if it has been added to the blade due to oxidation. While the blade is similar in appearance to a French model 1777 bayonet (ibid.:20), it could have been fabricated into a pike head, which was used around artillery sites as a defense against horsemen. It is also possible that it could be a variation of a Baker bayonet. While the majority of Baker bayonets used a flat sword blade and cast brass grip with counterguard, the first model hand bayonet was created in 1823 which used a triangular blade with iron tang that fitted into a brass handle. The second pattern Baker hand bayonet was introduced in 1826 and used a shorter triangular blade and 1 ighter weight grip (Wilkinson-Latham 1971:72-73). It continued to be used until the end of Baker production in 1838.

\section{Knife Blades}

Provenience: $T-3, W-6, X-1-4, S-3$ (Figs. $26, a, b ; 27, a, b$ )

Four iron knife blade fragments were recovered, a 11 badly oxidized. The blade from $T-3$ weighs $50.5 \mathrm{~g}$ and is $14.5 \mathrm{~cm}$ long ( $F$ ig. 26,b). The blade from W-6 weighs $56.2 \mathrm{~g}$ and is $12.3 \mathrm{~cm}$ long ( $F$ ig. $27, \mathrm{~b}$ ). The blade from $x-1-4$ weighs $40.5 \mathrm{~g}$ and is $11.5 \mathrm{~cm}$ long ( $F$ ig. $27, \mathrm{a}$ ). The b 1 ade from $\mathrm{s}-3$ weighs $79 \mathrm{~g}$ and is $14.2 \mathrm{~cm}$ long ( $F$ ig. 26, a). Typical blades have a tang for attaching the grips, a 2.85-cm-wide "choij" or shoulder, and taper to a straight-topped, single-edged point. These patterns conform perfectly to the a1 1-purpose be 1t knives (Brinckerhoff and Chamberlain 1972:112) in common use throughout Mexico in the 18th and early 19th centuries. 
a
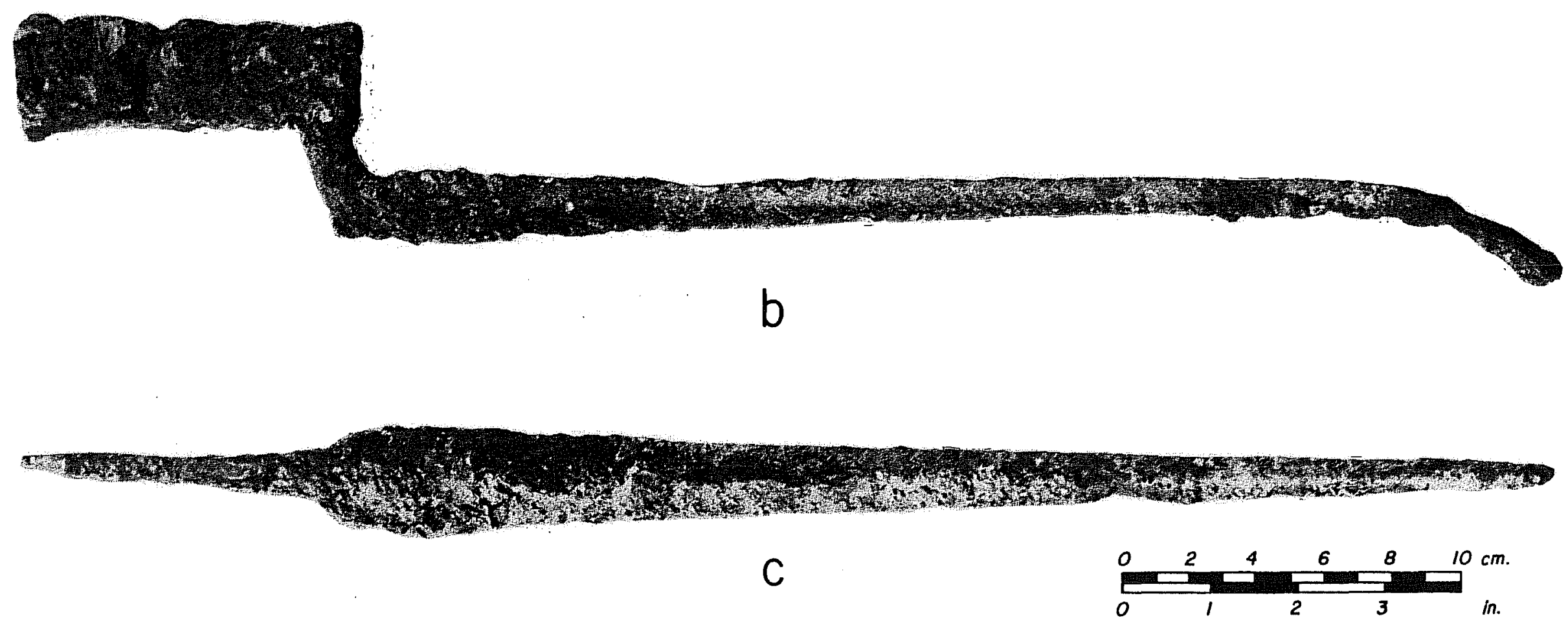

Figure 28. Bayonets and Possible Pike Head. a, badly oxidized triangular blade and shank portion from a bayonet which was manufactured for use on the British-made Brown Bess musket; b, badly oxidized triangular blade bayonet, missing only the tip, manufactured for use on the Brown Bess musket; c, badly oxidized triangular blade pike head or bayonet. A pike head was attached to a long wooden shaft and was a common weapon used around artillery sites as a defense against mounted horsemen. 


\section{Bits}

Provenience: J-7, L-3 (F ig. 29, a)

Fragments of two iron snaffle bits were recovered. The specimen from $\mathrm{J}-7$ is a four-rein snaffle-curb bit with curved sidebars (Fig. 29,a). One fragment of a broken sidebar is $13 \mathrm{~cm}$ in length. The lower part in the sidebar is $1.5 \mathrm{~cm}$ in diameter. The specimen from $L-3$ is a fragment of a straight sidebar and snaffle section from a Pelham bit. The fragment of the broken sidebar is $11.5 \mathrm{~cm}$ long, while the snaffle section is $7.5 \mathrm{~cm}$ in length. The snaffle-curb bit is very similar in style to a Pelhambit, except for the curved sidebars (Vernam 1964:262). Both patterns are very much 1 ike a style in use by the Mexican cavalry in the $1820 \mathrm{~s}$ (Nieto, Brown, and Hefter 1958:P1ate II).

\section{Stirrup}

Provenience: C-3 (Fig. 30,C)

One 1 ightweight iron stirrup of a simple arch with foot plate was recovered. The sidebar of the frame is $13 \mathrm{~cm}$ in length and graduates in width from $1.5 \mathrm{~cm}$ to $0.7 \mathrm{~cm}$. There is a slot $(3.8 \mathrm{~cm}$ in 1 ength) at the top for a strap. Foot plate bars form an oval tread, the opening of which is $3.5 \mathrm{~cm} 1$ ong and $0.7 \mathrm{~cm}$ wide. This type of stirrup was in common use on European-style cavalry saddles from the 1 ate 18 th and early 19th centuries (Peterson 1968:201-211). This was also true of Mexican cavalry saddles of the 1820s.

\section{Spur Rowel}

\section{Provenience: $M-5$ ( $F$ ig. $30, b$ )}

An iron eight-pointed spur rowel with one point missing is approximately $6.8 \mathrm{~cm}$ in diameter. The maximum length of each point is about $2.5 \mathrm{~cm}$. The style is typical of Mexican construction during the early part of the 19th century (Vernam 1964:315) and probably denotes civilian rather than military usage.

\section{Horseshoes}

Provenience: $F-4, D-3$ BALK, I-1 (Fig $29, b-d$ )

Fragments of three iron horseshoes were recovered. The fragment from F-4 is $12.7 \mathrm{~cm}$ long and $2 \mathrm{~cm}$ wide. The branch which is present is heavily oxidized, but appears to have four heavily encrusted holes. There is no calkin or cleat present on the hee1. As there is some degree of wear to the right toe, it may be for a right forefoot ( $F$ ig. $29, \mathrm{c}$ ). The specimen is a handmade type III shoe from the 19th century (Noêl Hume 1973:105). The specimen from D-3 BALK is a similar branch, that weighs $25.8 \mathrm{~g}$ and is $9.8 \mathrm{~cm}$ wide (Fig. $29, d$ ). The fragment from I-I is a wider, heavier shoe (Fig. 29,b). The branches are $3.5 \mathrm{~cm}$ wide, and the shoe appears to be $8 \mathrm{~cm}$ in length. The branches taper 
slightly, and there are no calkins present. There are four handmade holes present on each branch. A 1769 source identifies the type as Spanish in origin (ibid.:106-107). It is likely, however, that the style continued into the early 19th century.

\section{Buttonse Flat One-Piece}

Provenience: $D-6, L-3, L-5 C-2, D-2, B D(2), Q-F I L L, M-5, D-3, P-5, T-3, D-4$ (Fig. $31, \mathrm{C}-0$ )

Thirteen $p l a i n$ brass buttons of 7 arge and smal 1 sizes were recovered. It appears the brass shanks are cast as one piece. The button from D-6 is in the best condition; it weighs $4 \mathrm{~g}$, i. $2 \mathrm{~cm}$ in diameter, and is $0.2 \mathrm{~cm}$ thick. The shank on the back stands $0.5 \mathrm{~cm}$ high. This button has the on $1 \mathrm{y}$ legible backmark, which is ". . . STANDARD" in English Gothic letters (Fig. 31,k). The button from $L-3$ weighs $4.4 \mathrm{~g}$ and is $1.9 \mathrm{~cm}$ in diameter (Fig. $31, i$ ). The button from L-5 weighs $3 \mathrm{~g}$ and is $1.85 \mathrm{~cm}$ in diameter (Fig. $31, \mathrm{~h}$ ). The button from $\mathrm{C}-2$ weighs $3 \mathrm{~g}$ and is $2 \mathrm{~cm}$ in diameter ( $F i g .31, n$ ). The specimen from $D-2$ is badty oxidized and weighs $3.1 \mathrm{~g}$ and has a diameter of $1.85 \mathrm{~cm}$ (Fig. 31,1$)$. One of the two buttons recovered from $B D$ is broken and is $2.3 \mathrm{~cm}$ in diameter (Fig. $31, \mathrm{~m}$ ), and the other one is still embedded in the matrix (Fig. 31,0). The button from Q-FILL weighs $1.1 \mathrm{~g}$ and is $1.75 \mathrm{~cm}$ in diameter. The shank is missing from this specimen ( $F i g .31, j$ ). The specimen from $M-5$ is a smaller cuff button ( $F i g .31, C$ ) that weighs $1.3 \mathrm{~g}$ and is heavily encrusted. It is $1.45 \mathrm{~cm}$ in diameter with a $0.25 \mathrm{~cm}$ shank. The specimen from $D-3$ is a plain-face brass button with an intact brass shank. It is $1.45 \mathrm{~cm}$ in diameter and weighs $1.4 \mathrm{~g}$ ( $F$ ig. $31, \mathrm{~d})$. The button from P-5 is a brass fragment that weighs $2.1 \mathrm{~g}$ and is $1.8 \mathrm{~cm}$ in diameter ( $F i g .31, e$ ). The $p l a i n-f a c e$ brass button from $T-3$ has an intact brass shank ( $F i g .31, g$ ). The shank is $0.25 \mathrm{~cm}$; the button weighs $3.1 \mathrm{~g}$ and has a diameter of $1.85 \mathrm{~cm}$. The button from D-4 weighs $1.5 \mathrm{~g}$ and is $1.45 \mathrm{~cm}$ in diameter (Fig 3l,f). This type of plain-face button has a wide time span (Jenkins 1973:3-4), and is difficult to date. It was used from the 18th century to near the middle of the 19th century. It was also the standard issue button for enlisted men of the Mexican army. Dismounted officers received a gold-plated button engraved with the eagle and serpent, unless they were cavalry officers in which case the button was silver-plated. It is bel leved the 1 arger buttons were used on the front of the 1832 and 1833 contract tunics, while the smaller ones were used on the 1833 regulation cuffs.

\section{Buttons, Bullet}

\section{Provenience: $\mathrm{J}-2, \mathrm{C}-4$ (Fig. $31, \mathrm{~b}$ )}

Round brass buttons were named bullet buttons because of their similarity to a rifle bal1. The specimen from J-2 (Fig. 31,b) is the most complete of the two and weighs $2 \mathrm{~g}$. It has a diameter of $1.25 \mathrm{~cm}$ and a thickness of $1 \mathrm{~cm}$. There is a brass shank present $0.15 \mathrm{~cm}$ high. The button from $\mathrm{C}-4$ is in a badly oxidized state, but also weighs $2 \mathrm{~g}$. It is $1.3 \mathrm{~cm}$ in diameter and $1.1 \mathrm{~cm}$ thick. The date for this type of button is from the early 19th 
Figure 29. Horse Equipment.

a, badly oxidized four-rein snaffle-curb bit with curved sidebars. This style is very much like a style in use by the Mexican cavalry in the 1820s;

b, badly oxidized eight-hole horseshoe that has the calkins missing from both branches;

c, badly oxidized fragment of handmade horseshoe, possibly for the right fore foot;

d, badly oxidized fragment of a handmade horseshoe. 


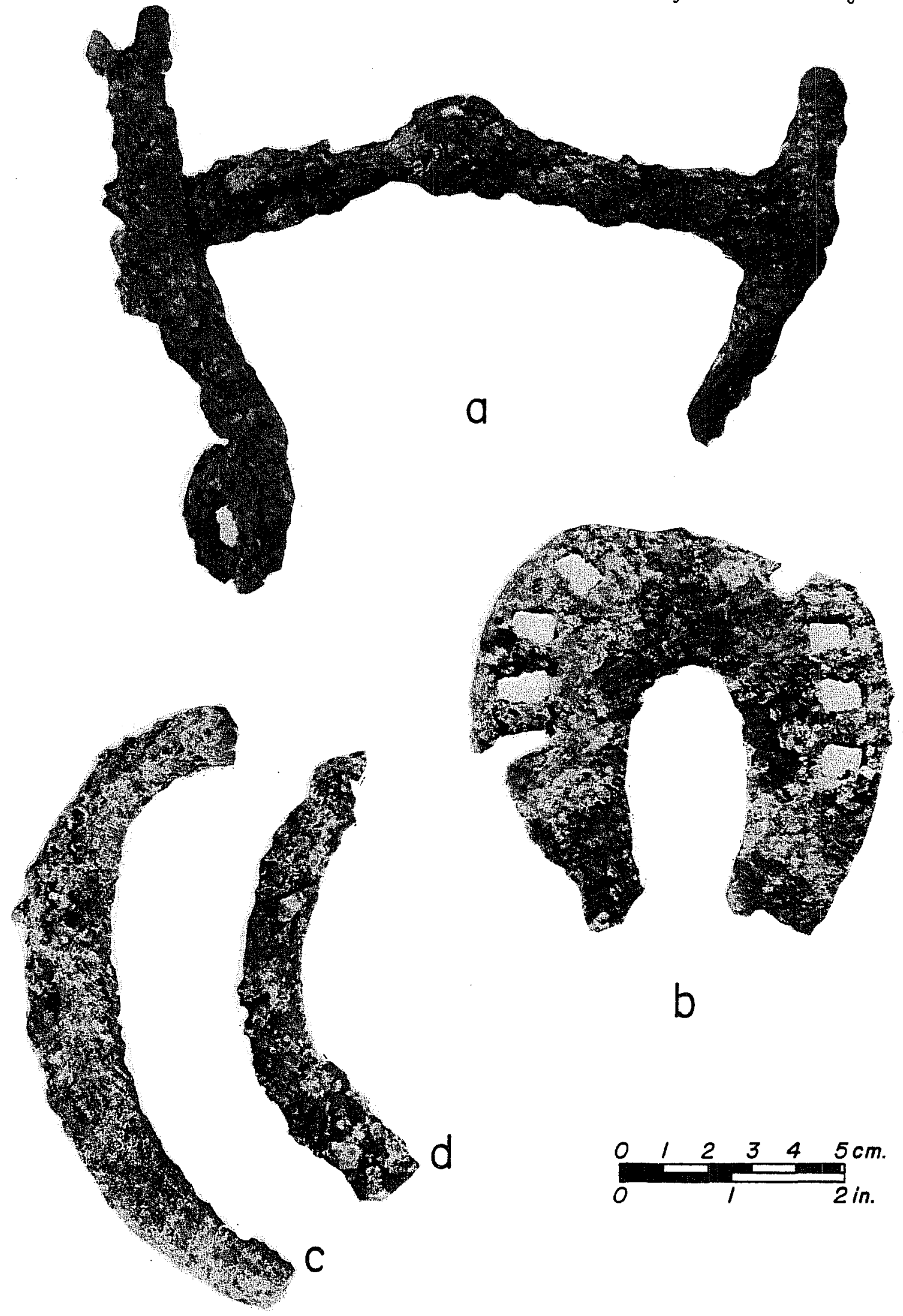


Figure 30. Butt P1ate, Spur Rowe1, and Stirrup.

a, brass butt plate from an India Pattern Brown Bess musket;

b, iron eight-pointed spur rowel typical of Mexican construction during the early part of the 19th century probably denotes civilian rather than military usage;

c) 1 ightweight iron stirrup with a slot at the top for the strap. This style was in common use on both the European and Mexican style cavalry saddles during the early 19th century. 


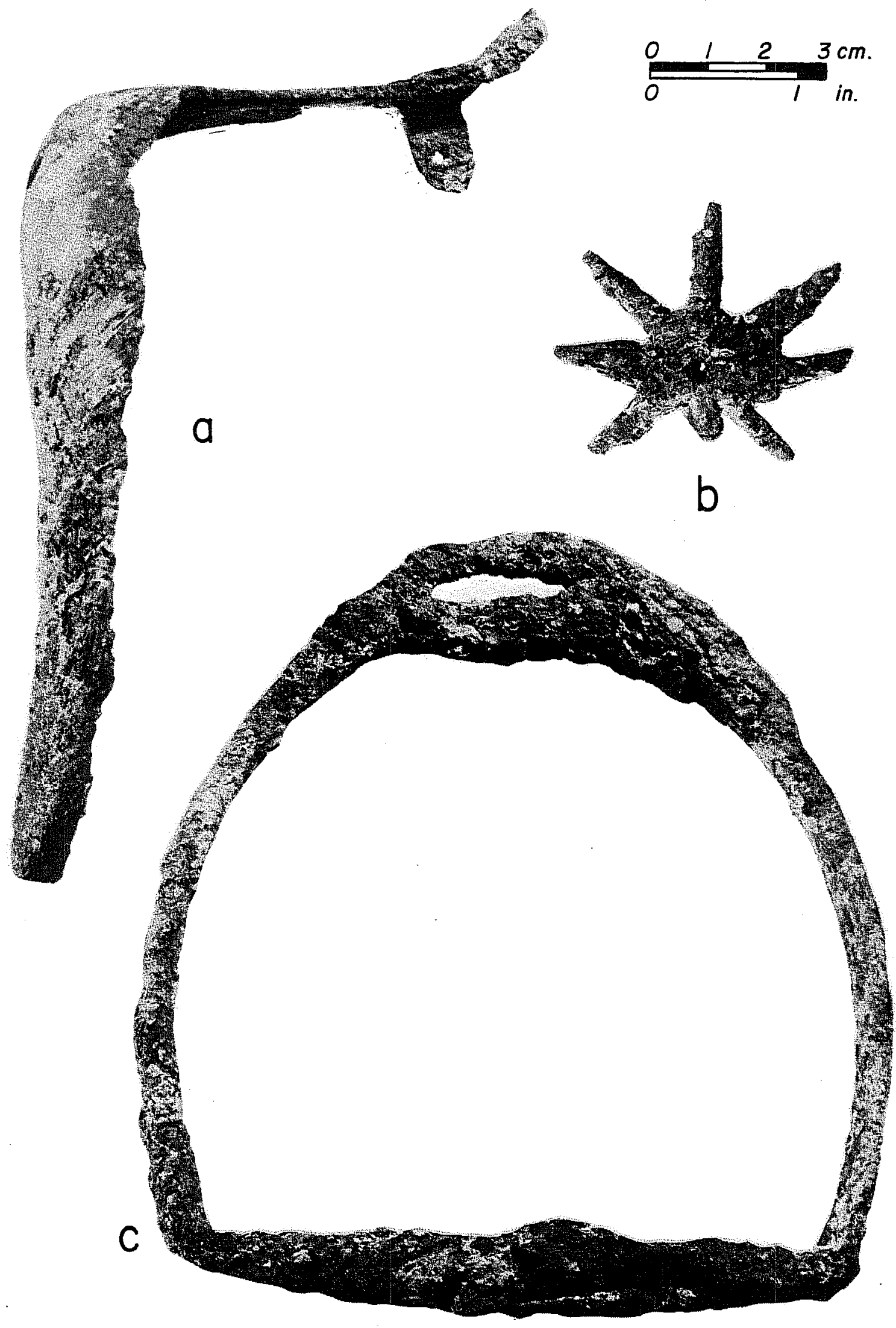


Figure 31. Buttons, Hooks, and Buckles.

a, brass hook of double-wire construction;

b, bullet-type brass button with intact brass shank;

c, plain-face brass cuff button with intact brass shank;

d, plain-face brass cuff button with intact brass shank;

e, fragment of a plain-face brass button without shank;

$f$, plain-face brass button with intact brass shank;

$g$, plain-face brass button with intact brass shank;

$h$, plain-face brass button with intact brass shank;

$i$, plain-face brass button with intact brass shank;

$j$, plain-face brass button without brass shank;

k, plain-face brass button with ". . STANDARD" impressed on the reverse of the button;

1, badly oxidized brass button without shank;

$m$, broken plain-face brass button without shank;

$n$. plain-face brass button with intact brass shank;

o, badly oxidized button encrusted in soil matrix;

p, double-sided brass buckle of a type similar to those used on a military belt or used as strap buckles for cartridge boxes;

$q$, single-sided brass buckle with intact central tine;

$r$, double-sided buckle possibly from a military belt or strap buckle for a cartridge box.

It is felt that the larger buttons were used on the front of the 1832 and 1833 contract tunics, while the smaller ones were for the 1833 regulation cuffs on uniforms worn by the Mexican army during the second battle of the Alamo. 


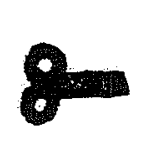

a

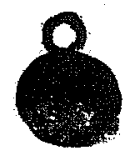

b

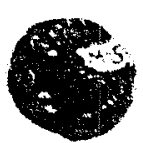

C

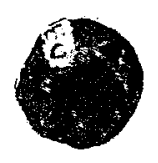

d
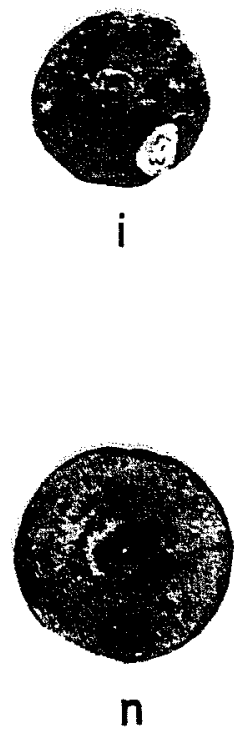

n

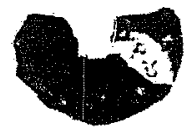

e

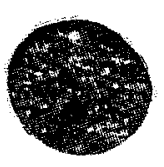

$f$

k

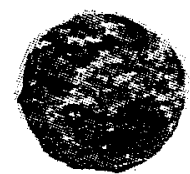

g
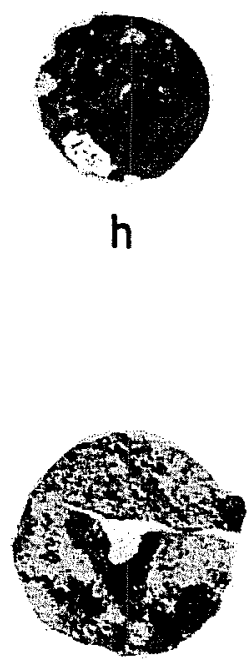

m

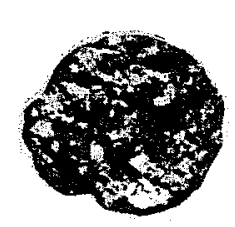

I
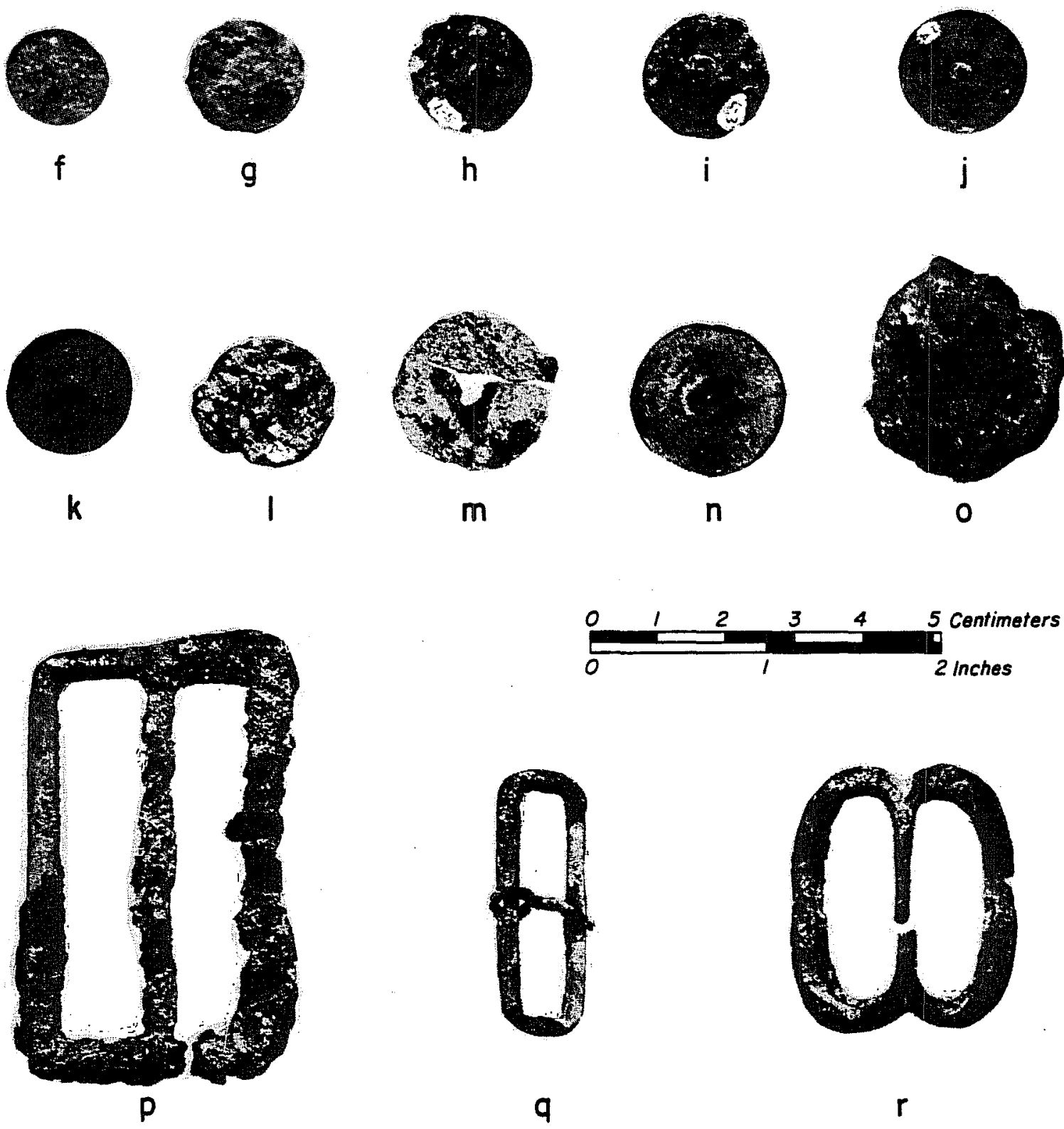

q

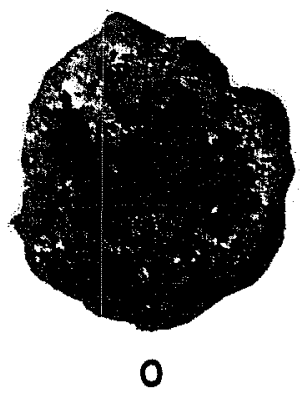
2 inches

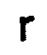


century (Wyckoff 1984:64) and was usual 1y found on general staff, hussar, some artillery, and militia tunics.

\section{Hooks and Eye}

Provenience: $\mathrm{C}-7, \mathrm{~J}-6(2)$ (Fig. $31, \mathrm{a})$

Fragments were recovered of two brass hooks and an eye to close the col1 ar of tunics. Both hooks have the standard double-wire construction with two loops for sewing. The eye from $\mathrm{J}-6$ is a single brass 100 p that weighs $0.25 \mathrm{~g}$ and is $1.5 \mathrm{~cm}$ long. The hook from $\mathrm{J}-6$ was found in association with the eye and weighs $0.5 \mathrm{~g}$. It is $1 \mathrm{~cm}$ wide and $2.3 \mathrm{~cm}$ 1ong. The specimen from $\mathrm{C}-7$ (Fig. $31, \mathrm{a}$ ) weighs $0.35 \mathrm{~g}$ and has a fragment of a hook $1 \mathrm{~cm}$ wide and $1.25 \mathrm{~cm}$ long.

\section{Buckles, Brass}

\section{Provenience: $\mathrm{D}-7, \mathrm{C}-7, \mathrm{M}-7$ (Fig. $31, \mathrm{p}-\mathrm{r}$ )}

Two brass buckles are broken, and one is intact. The buck le from D-7 is in two pieces with a corner broken. It is double-sided with the tine missing from the central bar. The corners are slightly rounded, and the casting is flat on the reverse. It weighs $28.25 \mathrm{~g}$ and is $4.2 \mathrm{~cm}$ wide and $7 \mathrm{~cm} 1 \mathrm{ong}$, averaging $0.35 \mathrm{~cm}$ in thickness (Fig. $31, \mathrm{p}$ ). The buckle from $\mathrm{C}-7$ has a single-side, weighs $5 \mathrm{~g}$, and is $1.4 \mathrm{~cm}$ wide and $4.35 \mathrm{~cm}$ long. It stil 1 has the brass tine present, which is $1.75 \mathrm{~cm}$ long ( $F i g .31, q)$. The specimen from $M-7$ is a double-sided buckle with the top and bottom indented to form double ovals (Fig. $3 l, r)$. The central bar is fractured, and the tine is missing. It weighs $10 \mathrm{~g}$ and is $3.45 \mathrm{~cm}$ wide, $4.3 \mathrm{~cm}$ long, and $0.25 \mathrm{~cm}$ thick. It is bel ieved that the buckles from $D-7$ and $M-7$ were probably from a military belt or were shoulder strap buckles from cartridge boxes (Neumann and Kravic 1975:53). The buckle from C-7 was probably used for an adjustable cloth belt on the back of a pair of men's trousers.

\section{SUMMARY AND CONCLUSIONS}

The battle of the Alamo continues, after a century and a half, to be one of the most widely discussed topics among military historians. There is something about the engagement that fires the imagination and endures. The original historical sources of information for both sides are amazingly few. On the defenders' side, there are only the reports and letters of the post's commander, along with the few confused eyewitness accounts from a handful of noncombatant survivors. A11 others perished on a fateful morning in March.

Among the attacking forces, there were no shortages of survivors, many of whom in their later years would write their memoirs based on recollections of that day. There are again some discrepancies in the details, depending upon their memory and point of view. The Mexican sources should be careful1y studied, however, because (1) they were the only combatants that survived the day; and (2) they were in control of the field and were able to make 
unhurried, first-hand observations. Despite these facts, we still know remarkably 1 ittle about the Mexican forces involved in the siege. Exactly where were they deployed, what was their strength, and which weapons were in use?

As the original participants are no longer available for questioning, archaeology is the only hope available to answer some of our remaining questions. The succeeding years have taken their toll on the urban area, and there are now relatively few sites left to excavate. We were very fortunate that 41 BX 677 was somehow preserved and that we were able to excavate the site. Any material recovered that relates to the battle of the Alamo is rare; Mexican military artifacts from an earthwork have been nonexistent. Only at Goliad has a substantial collection of Mexican military artifacts been excavated from a site in Texas. Only through the recovery of such artifacts are we able to visualize the Mexican army of 1836.

But you may ask why do these artifacts have to be associated with the battie of the Alamo? Why not an earlier or later period? It is true that San Antonio has long been a center for military activity in Texas. However, the filibustering expeditions and early battles for Mexican independence would not have yielded the bal ance of artifacts recovered from this site. It is true that some of the solid shot, buttons, and horse equipment could date from that early, but they also continued in use during the next 30 years. With the exception of a possible quartel site in the area of La Villita, there was no other military activity in that location. Everything else was centered in defensive sites in the town of Bejar or in the A 1 amo. The main reason the site could not date from an earlier period is the 1 arge number of British gun parts recovered. During the Napoleanic Wars, Britain. was considered an enemy of Spain, and there was hardly an opportunity for trade between the two belligerents. It is also folly to suppose that Spain could have captured the arms from England and supplied them on a 1 arge enough scale to equip their army in Mexico. The first time we find mention of British firearm sales to Mexico is in the early 1830 s. It is true that some Texans in the Alamo were using Brown Bess muskets surrendered by Cos in 1835, but never on a scale large enough to equal those in use by the Mexican forces opposing them.

If we, therefore, accept that the site was in use during the 1835-1836 period, the various possibilities of use and troops involved can be discussed. The artillery projectiles in themselves are not surprising, despite the fact that this is the only known example of an unfired howitzer shell found in Texas. From numerous historical accounts, there was a Mexican artillery battery south of the $A l$ amo in the area of La Villita of which one of the pieces was a howitzer. It is 1 ikely that the artiliery battery was in close association with the site, as the shell would probably not have been moved very far because of its weight. The numerous musket bails recovered from the site could have been used as shrapnel in the shel1 or could have been related to the numerous Brown Bess musket parts recovered. It would be unusual to have an artillery battery on the location without some infantry nearby as support. The musket parts are probably from an infantry battalion, as it would have been unusual for artillerymen to have had first-line muskets available to them. 
We know there were infantry units in the area of La Villita prior to the battle, as an attacking column was 1 aunched from that area on the morning of March 6 using the Activo Battalion of "San Luis Potosi" and the scouting companies of the Permariente Battalions "Matamoros" and "Jimenez." The grenadier companies of these three battalions would remain as a reserve. While the ordinary 1 ine companies were armed with Brown Bess muskets, the rifle companies would have been armed with Baker rifles. It is interesting to note that in Santa Anina's general order for the attack, he stated that "as soon as the moon rises, the riflemen of the Activo Battalion, 'San Luis', wi11 move back to their quarters to get their equipment ready; this wil1 be done by leaving their stations in the 1 ine!! (Sanchez Lamego 1968:33). Presumably since this company was part of the San Luis Potosi battalion and would attack with the southern column, their station in the 1 ine was north of the Alameda, while their quarters, or "quartel" were probably in some of the surviving houses in the area of La Villita.

The cavalry, consisting of the Permanente Regiment "Dolores," was under the command of General Ramirez y Sesma. Their duty during the attack was to occupy the Alameda behind the infantry and keep anyone from deserting (ibid.). Their other task was to guard the camp. probably south of the Alameda in the area of La Vil1 ita. Later the cavalry force may have been supplemented by the "Tampico" regiment, which joined "Dolores." It was natural for the cavalry camp to have been placed in the southeastern part of town, as grazing was good during the spring months along the San Antonio River and that was the direction from which an attacking Texan force wou $1 \mathrm{~d}$ most likely come.

After the Alamo had fallen, like in any army, there was the job of "pol icing up" the area. The Texan bodies had to be burned and the debris of war removed. During the ensuing months, the occupation forces that remained in San Antonio and did not move eastward with Santa Anna were responsible for the long garrison routine. It was a chance to rest a bit and care for the wounded recovering from the battle. The tranquilty was broken in 1 ate April when word arrived that Santa Anna and the balance of the pursuing army had been badly defeated at San Jacinto. The terms of the surrender specified that all Mexican forces withdraw below the Rio Grande. In the haste born of desperation, the Mexican forces in San Antonio began spiking the guns left behind and destroying the material they could not take with them. No point leaving anything behind for the Texas army to use. They never knew when they might have to meet them on the field of combat again. The weather was turning bad, reflecting their mood, when the spring rains began. Perhaps some of the damaged war material from the area went into the existing ditch behind La Villita. It would be a long time before the Texans would see those items again! 


\section{REFERENCES CITED}

Bartieson, J. D., Jr.

1972 A Field Guide for Civil War Explosive Ordnance, 1861-1865. U.S. Nava 7 Schoo1, Explosive Ordnance Disposa 1. U.S. Nava 1 Ordnance Station, Indian Head, Maryland.

Brinckerhoff, S. B. and P. A. Chamberlain

1972 Spanish Military Weapons in Colonial America, 1700-1821. Stackpole Books, Harrisburg. Pennsyl vania.

Butler, D. F.

1971 United States Firearms, the First Century, 1776-1875. Winchester Press, New York.

Calver, W. L. and R. P. Bolton

1950 History Written with Pick and Shovel. Relics Excavated from Colonial, Revolutionary and War of 1812 Camp Sites. The New York Historical Society, New York.

Darling, A. D.

1970 Red Coat and Brown Bess. Museum Restoration Service, Historical Arms Series 12. Ottawa, Ontario.

Eaton, J. D.

1980 Excavations at the ATamo Shrine (Mission San Antonio de Valero). Center for Archaeological Research, The University of Texas at San Antonio, Special Report 10.

Gooding, S. J.

1965 An Introduction to British Artillery in North America. Museum Restoration Service, Historical Arms Series 4. Ottawa, Ontario.

Hefter, J.

1968 Cronica del Traje Militar en Mexico del Siglo XVI al XX. Artes de Mexico, No. 102, Ano XV. With translation in English, French, and German. Mexico, D.F.

Institute of Texan Cultures

1971 The Mexican Texans. The University of Texas, Institute of Texan Cultures, San Antonio. 
Institute of Texan Cultures (continued)

1975 The Anglo-American Texans. The University of Texas, Institute of Texan Cultures, San Antonio.

James, $G$.

1983 The Historic Baker Rifle. Guns and Ammo 27(11):52-56, 90-92, November.

Jenkins, D.

1973 Military Buttons of the Gulf Coast, 1711-1830. Museum of the City of Mobile, Alabama.

Kirkland, T.

1984 Dixie Gun Works, Inc., Catalog No. 133. Published by author, Union City, Tennessee.

Koury, M. J.

1973 Arms for Texas. A Study of the Weapons of the Republic of Texas. The $01 \mathrm{~d}$ Army Press, Fort Coll ins, Colorado.

Lord, W.

1961 A Time to Stand. Harper and Brothers, New. York.

McKee, W. R. and M. E. Mason, Jr.

1980 Civil War Projectiles. II, Small Arms and Field Artillery, with Supplement. Moss: Publications. Orange, Virginia.

Meuse, W. A.

1965 The Weapons of the Battle of New Orleans. The Battle of New Orleans, 150th Anniversary Committee of Louisiana, New Orleans.

Miller, M.

1978 The Coll lector's Illustrated Guide to Firearms. Il lustration from Wal 1 is and Wal 1 is Ltd., Mayflower Books, New York.

Myatt, Major F. M. C.

1979 The Il lustrated Encyclopedia of 19th Century Firearms. A Sal amander Book, Crescent Books, New York.

Myers, J.

1948 The A1 amo. 1960 edition. Bantam Books, New York. 
Neumann, G. C.

1967. The History of Weapons of the American Revolution. Harper and Row, New York.

Neumann, G. C. and F. J. Kravic.

: 1975 Co1 1ector's I 11 ustrated Encyclopedia of the American Revolution. Stackpole Books; Harrisburg, Pennsylvania.

Nieto, A., Mrs. J. N. Brown, and J. Hefter

1958 El Soldado Mextcano, 1837-1847. No publisher given. Mexico, D.F.

NoëT Hume, I.

1973 Five Artifact Studies. Colonial Williamsburg Occasional Papers in Archaeology, Vol. 1., A Study of Horseshoes in the Dept. of Archaeology, Colonial Williamsburg. Chappe1, Edward. Colonial Wi11 iamsburg Foundation, Williamsburg, Va.

Perry, C., translator and editor

1975 With Santa Anna in.Texas. A Personal Narrative of the Revolution by José de 1 a Peña. Texas A\&M University Press, . Col lege Station.

Peterson, H. L.

1968 The Book of the Continental Solider. Stackpole Books, Harrisburg, Pennsylvania.

Ripley, W.

1970 Artillery and Ammunition of the Civil War. Van Nostrand Reinhold Company, New iYork.

Robson, B.

1975 Swords of the British Army, The Regulation Patterns; 17881914. Arms and Armour: Press, London.

Sanchez Lamego, General Miguel A.

1968 The Siege and Taking of the Alamo. Translated by Consuelo Velasco with some comments on the battle by J. Hefter. The Press of the Territories, Santa Fe, New Mexico.

Sanchez Navarro, C.

1960 La Guerra de Texas. Memorias de un Soldado. Editorial Jus, Mexico. 
Santos, R. G.

1968 Santa Anna's Campaign Against Texas, 1835-1836. Texian Press, Waco, Texăs.

Thomas, D. S.

1981 Ready-Aim-Firel Small Arms Ammunition in the Battle of Gettysburg. Privately printed, Arendtsvili le, Pennsylvania.

Tinkle, L.

1958 Thirteen Days to Glory. McGraw-Hi11, New York.

Travis, W. B.

1836 Letter to the President of the Convention; March 3, 1836. Telegraph \& Texas Register; March 12, 1836.

Vernam, G. R.

1964 Man on Horseback. Harper and Row, New York.

Webster, D. B., Jr.

1964 American Socket. Bayonets, 1717-1873. Museum Restoration Service, Historical Arms Series 3. Ottawa, Ontario.

Wilbur, C. K.

1969 Picture Book of the Continental Soldier. Stackpole Books, Harrisburg, Pennsylvania.

Wilkinson-Latham, J.

1971. British Cut and Thrust Weapons. Charles E. Tuttle Company Pub 1 ishers, Rutl and, Vermont.

Wyckoff, M. A.

1984 United States Mil itary Buttons of the Land Service, 1787-1902. A Guide and $\mathrm{Cl}$ assification System. McLean County Historical Society, Bloomington, Illinois. 


\title{
CHAPTER 5 \\ CERAMICS
}

\author{
Anne A. Fox
}

\section{INTRODUCTION}

From the first day of work on the site, it was apparent that this was an unusual artifact collection for several reasons. The first and most important to an archaeologist interested in historic ceramics was the seemingly endless variety of colors and patterns represented by the sherds. Add to this the fact that most were made during a time period of approximate 1 y 20 years, ca. 1830 to 1850 , and we have a collection of great help in identifying and dating not on $1 y$ this site but components of other sites in the San Antonio area. The comparatively tight dating achieved for this collection through the ceramics makes it possible also to date more accurately other types of artifacts found within the site for which we have not up to now had confident parameters. In other words, this is perhaps the first time that archaeologists can confidently put together a 7 ist of goods that were available to the average San Antonio household during the years of 1830 to 1850 .

Another important aspect of this collection is the comparatively high number of 1 arge sherds and the fact that in many cases nearly whole vessels can be assembled within the collection. To the archaeologist accustomed to dealing with collections where the 1 argest sherd might measure $2 \mathrm{~cm}$ across and where any two sherds could seldom be cross-mended, this seemed a bonanza. The opportunity thus afforded to study vessel shapes and complete patterns is essential to an understanding of the evolution of ceramic types, and will al low observations to be made on trade patterns and selective choice of ceramics in the early 19th-century village of San Antonio.

A preliminary examination was undertaken of the ceramics recovered from the site in order to determine the date of the trench fill and the manner in which it was deposited. Ceramics are particularly well suited for this sort of analysis since they can be dated through regular, known changes in style and technology. Pieces of a single vessel can also be identified through cross-mending between units and levels, giving important data on artifact distribution within the site. Since time and resources would not allow us to complete processing of the artifacts from the entire excavation, a group of five units from the center of the site was selected for primary concentration. As the artifacts from these units were 1 abeled and catalogued, the sherds were removed to a separate table, where those from each unit were sorted into types and patterns within types and mended where possible into individual vessel fragments. A provenience chart (Table 3) was composed, using basic ceramic types and forms of decoration commonly used in Texas. The entire five-unit collection was then resorted into groups according to types established by the chart, then into subgroups according to pattern and color. Cross-mending within these subgroups was carefully recorded as it was accomplished so as to determine the pattern of deposition of sherds from individual vessels with in the trench, both horizontally and vertically (Table 4, Fig. 32). The resulting sample was then ready for more detailed examination and analysis on a type-by-type basis. 
TABLE 3. PROVENIENCE OF CERAMIC SHERDS IN UNITS $\mathrm{J}, \mathrm{C}, \mathrm{D}, \mathrm{M}$, AND $U$

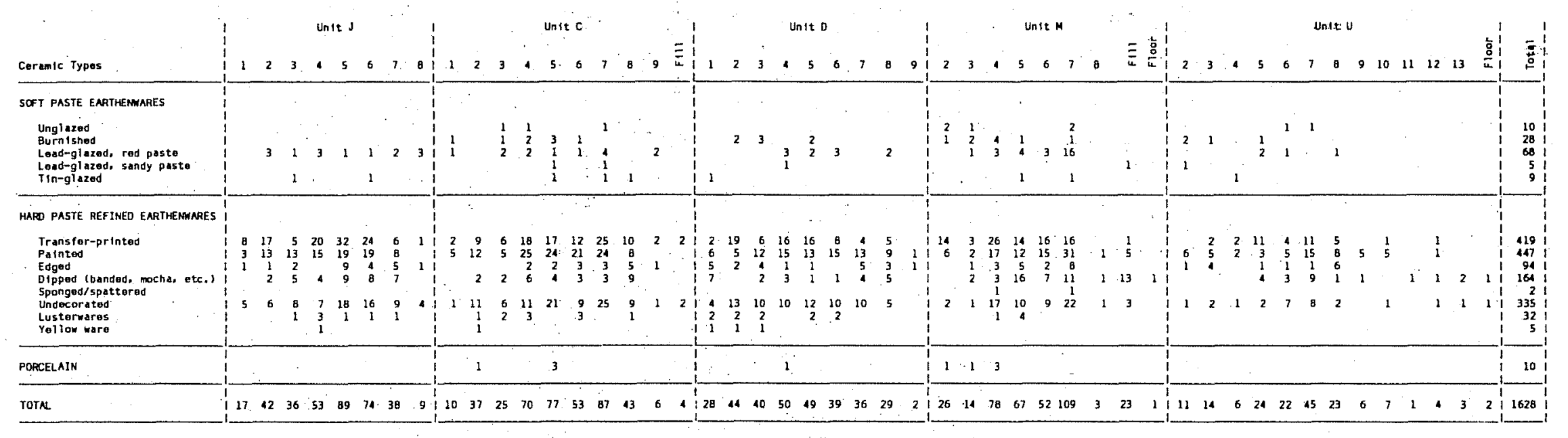


TABLE 4. RECORD OF CROSS-MENDING OF CERAMIC SHERDS

Ceramic Vesse1

B1ue transfer saucer

Red transfer saucer

Mulberry transfer plate

Polychrome painted saucer

Burnished bow 1

Mocha bow 1

Banded bow 1

Burnished bow1

Polychrome painted saucer

Blue transfer cup

Black transfer cup

Polychrome painted cup

Polychrome painted cup

Polychrome painted pitcher

S1ip-decorated bow 1

Slip-decorated pitcher

Banded slip pitcher
Units and Levels Represented

The ceramics have been divided into three main groups and a number of subgroups (Table 3 ). The groupings were chosen to reflect the physical properties of the ceramics. They a 1 so, interestingly enough, reflect the cultural background from which they came, the lower-fired earthenwares from the aboriginal and Mexican traditions of San Antonio and the refined white paste wares and stonewares from the English and European traditions.

\section{SOFT PASTE EARTHENWARES}

\section{Ungl azed Earthenwares (Fig. 33,b,e,f)}

Two types of unglazed, undecorated earthenwares are present. There are four sherds of 1oca1, hand-built bone-tempered ware, general1y called Goliad ware after the site where it first was identified and described (Fig. 33,b). This ceramic type appears to be a historic continuation of the ceramics made by the prehistoric peoples in south Texas (Ivey and Fox 1981:31). Another group of unglazed sherds has been wheel-turned (Fig. 33,e,f). The paste of these vessels appears identical to that of the lead-glazed red wares (described as follows). The sherds in both groups are too smal1 to determine vessel shape. 


\section{LEVEL CONCORDANCE, MITH CEAAMIC CROSS-MENDS}

\section{UNIT D UNIT C}

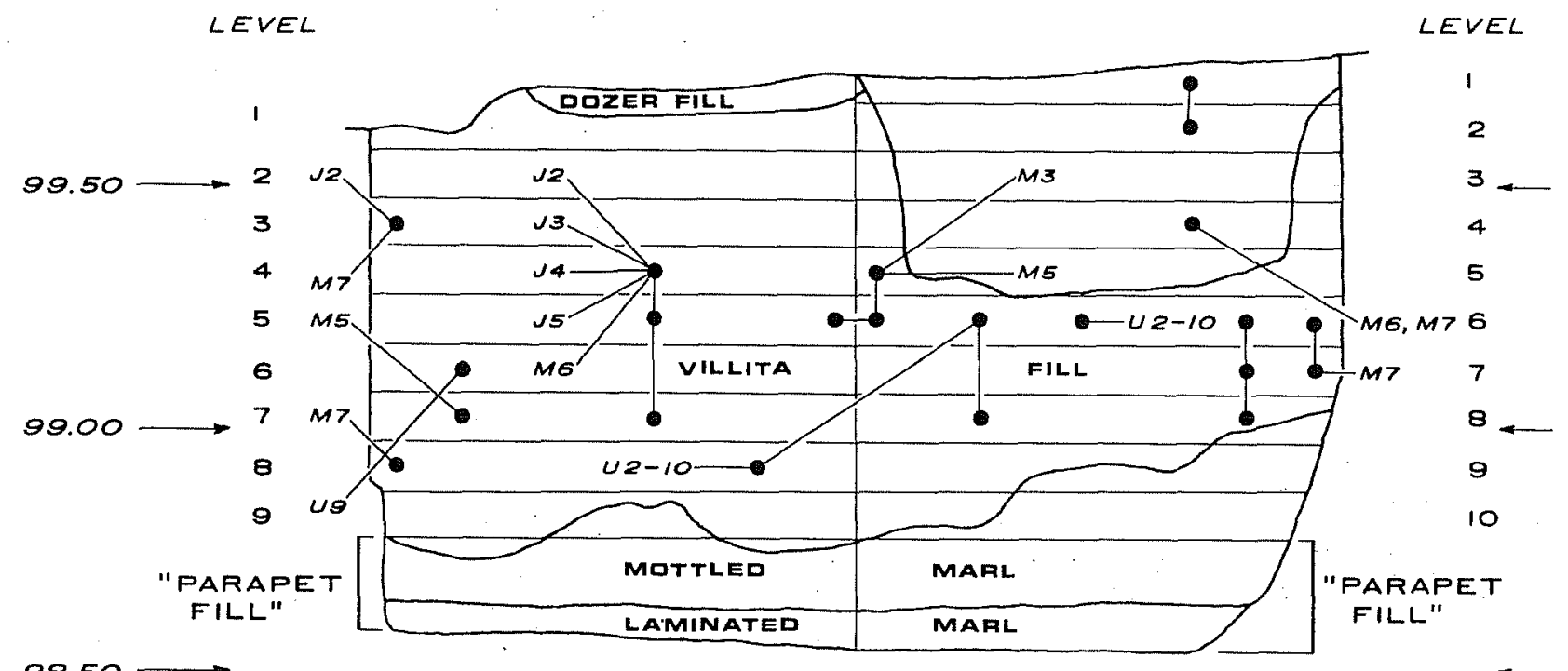

$98.50 \longrightarrow$

TMB 1985

Figure 32. Level Concordance, With Ceramic Cross Mends. Dots joined by 1 ines represent sherds successfully joined in laboratory processing. Only two excavations units, $C$ and $D$, are shown with their west wall profiles superimposed. Three other units (M, $U$, and $J$ ) checked are represented by unit and level codes shown outside the profile. Al so superimposed are the arbitrary excavation 1evels. Note level numbers for $C$ and $D$ are out of phase; al so note artibrary levels do not correspond very well to actual stratigraphy of the lowest deposits seen in the profile. Mottled marl and 1 aminated marl were 1 umped together in excavation and designated Parapet Fill. 
Burnished Earthenwares (Fig. 33,c,d and Fig. 34,a,b,e)

A sma 17 group of slip painted, burnished sherds in the collection were made in the town of Tonala in western Mexico (Schuetz 1969:52). The designs are in various shades of red, gray, and b 7 ack on a gray body ( $F i g .33, a, b, e$ ). The vessels appear to be bowls, one having a small strap handle near the rim. Similar vessels have been found in Spanish colonial sites throughout Texas.

Lead-Glazed Earthenwares (Fig. 33, a and Fig. 35,a-d)

Lead-glazed earthenwares can be basically divided into two groups according to paste and technology. Sherds in the red paste group represent smal1 jars and pots which were primarily mold-made in western Mexico. They were glazed on the interior and the upper section of the exterior with a clear lead glaze, and occasionally decorated with brown paint and/or cream ename 1 in bands and floral designs (Fig. 35,a-d). These ceramics appear in Texas about 1750 and continue into the early 1800s. Similar wares are still made in Mexico. This ceramic type is generally called Galera ware by archaeologists across the southwest (Ivey and Fox 1981:34).

Recovered were four sherds with a sandy paste and an orange or green lead glaze. Vessels represented cannot be determined, but ordinarily these are large, thick-walled, wheel-made utility vessels such as bow 7 and ol 1 as (Fig. 33,a).

\section{Iin-G]azed Earthentares (Fig. $34, c, d, f$ )}

Tin-glazed earthenwares are covered with an opaque, cream-colored glaze to which tin has been added. Designs are in green and rust. Several different designs are represented in this group (Fig. 34,c,d,f). Such vessels were made in the early part of the 19th century in potteries around Guanajuato, Mexico. Sherds of this type are common on early 19th-century sites in San Antonio.

Recovered was one tin-glazed sherd with a green-glazed exterior and white interior, originally from a French rouge pot (Georgeanna Greer, personal communication). This is a heavy, cylindrical vessel about two inches tall with an everted 1 ip and a bowl-shaped cavity three-fourths of an inch deep. Sherds of identical vessels have been found at other sites in San Antono, as well as at sites in New Orleans and Puerto Rico.

\section{HARD PASTE EARTHENWARES}

Refined Earthenwares (Fig. $36, a-i$ and Fig. 37,d-g)

Refined earthenwares are English white wares made for exportation to the United States in the first half of the 19th century. They arrived at the coastal ports of Texas in 1 arge quantities and were carted in 1 and to be sold in every major town. Methods of decoration were varied and colorful. Table 5 i ists the 1 arge assortment of colors and designs found just in the 
Figure 33. Soft Paste Earthenwares.

a, sandy paste, lead-glazed bow1;

b, tan, unglazed Goliad ware body sherd, vessel shape unknown;

c, red slipped, unglazed burnished body sherd, vessel shape unknown;

d, red slipped, burnished unglazed body sherd, vessel shape unknown;

e, wheel-turned, unglazed basal sherd from a bow 1 ;

f, wheel-turned, unglazed rim sherd from a large shallow bowl. 

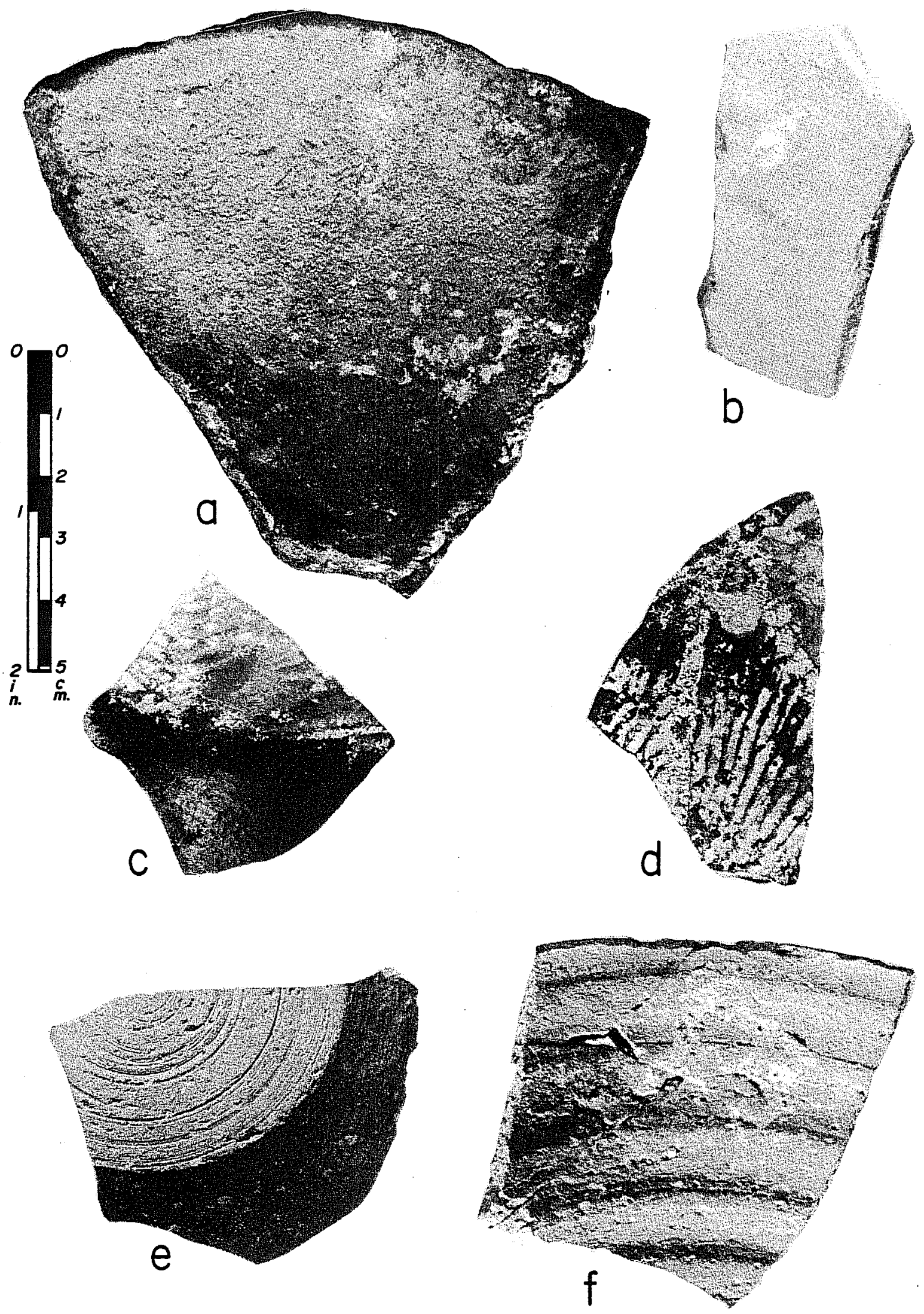
Figure 34. Burnished and Tin-Glazed Earthenwares.

a, burnished rim sherd, red and black on gray decoration, gray paste, from a large shallow vessel;

b, burnished body sherd, gray on black decoration, gray paste, vessel shape unknown;

c, Guanajuato tin-glazed, red paste, red and brown decoration, vessel shape unknown;

d, tin-glazed body sherd, 1 ight green, red paste, from a deep plate;

e, burnished body sherds from same vessel as in a;

f, Guanajuato tin-glazed, red paste, red and brown on cream background, from a plate. 

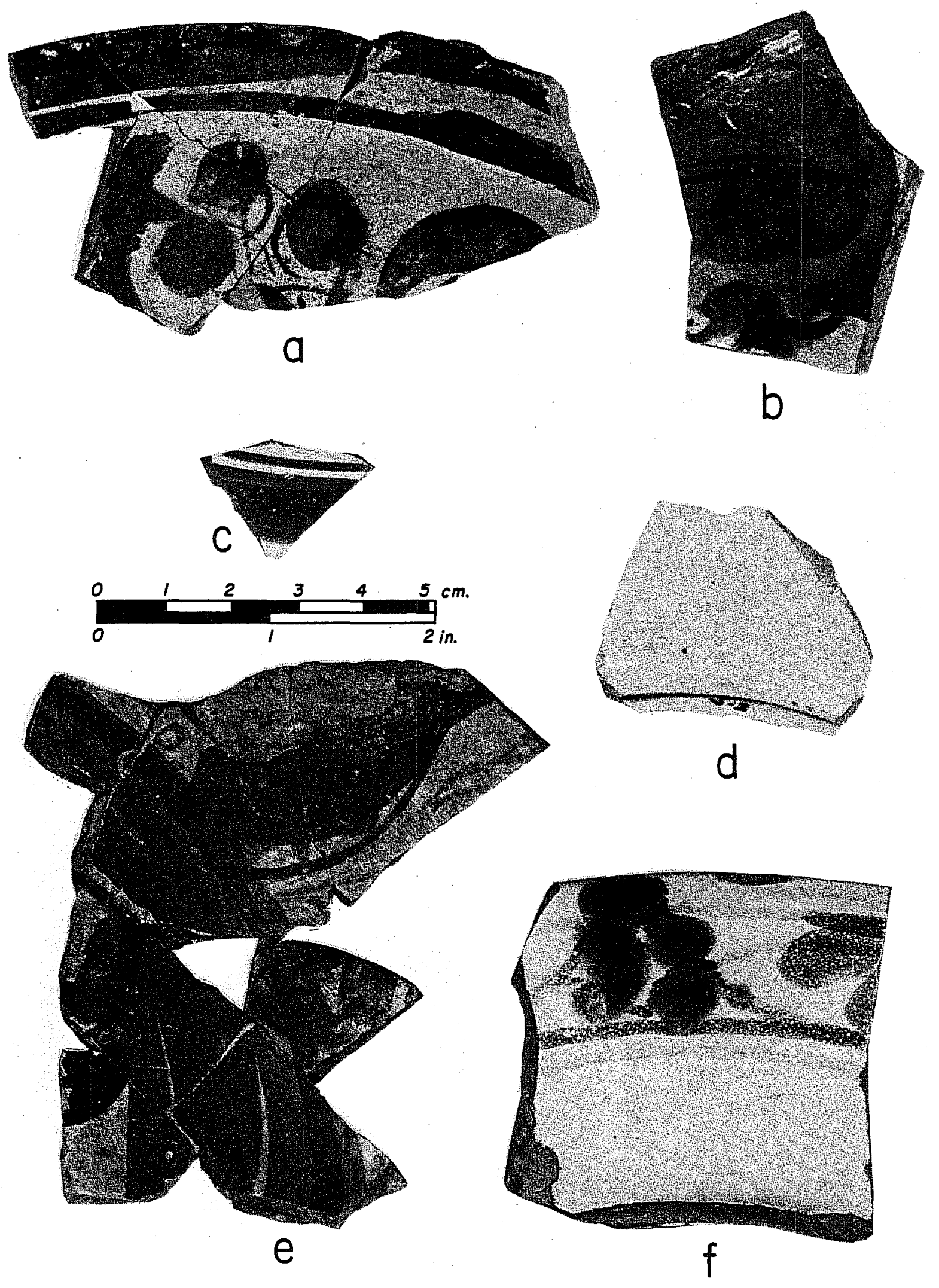

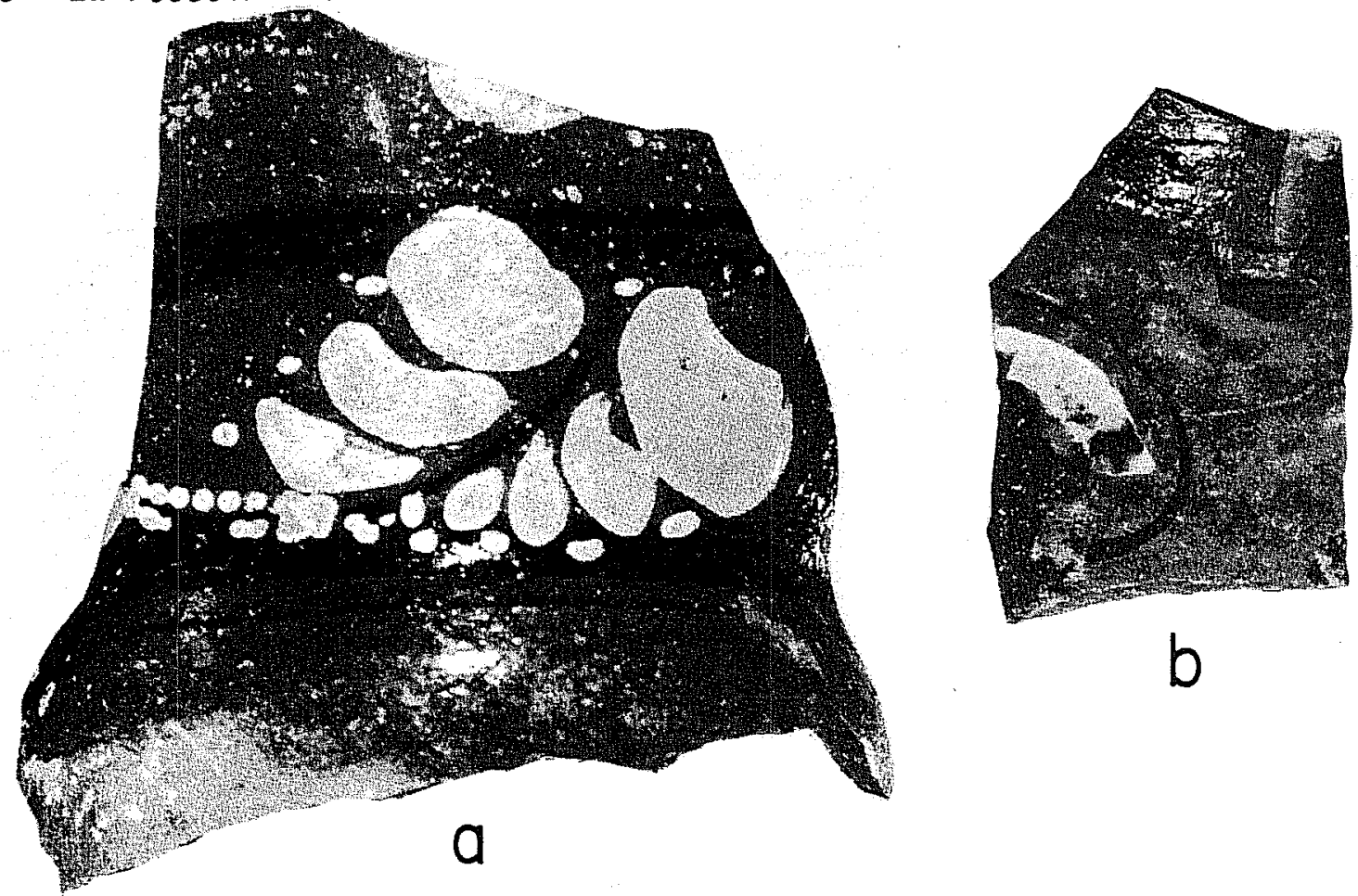

b
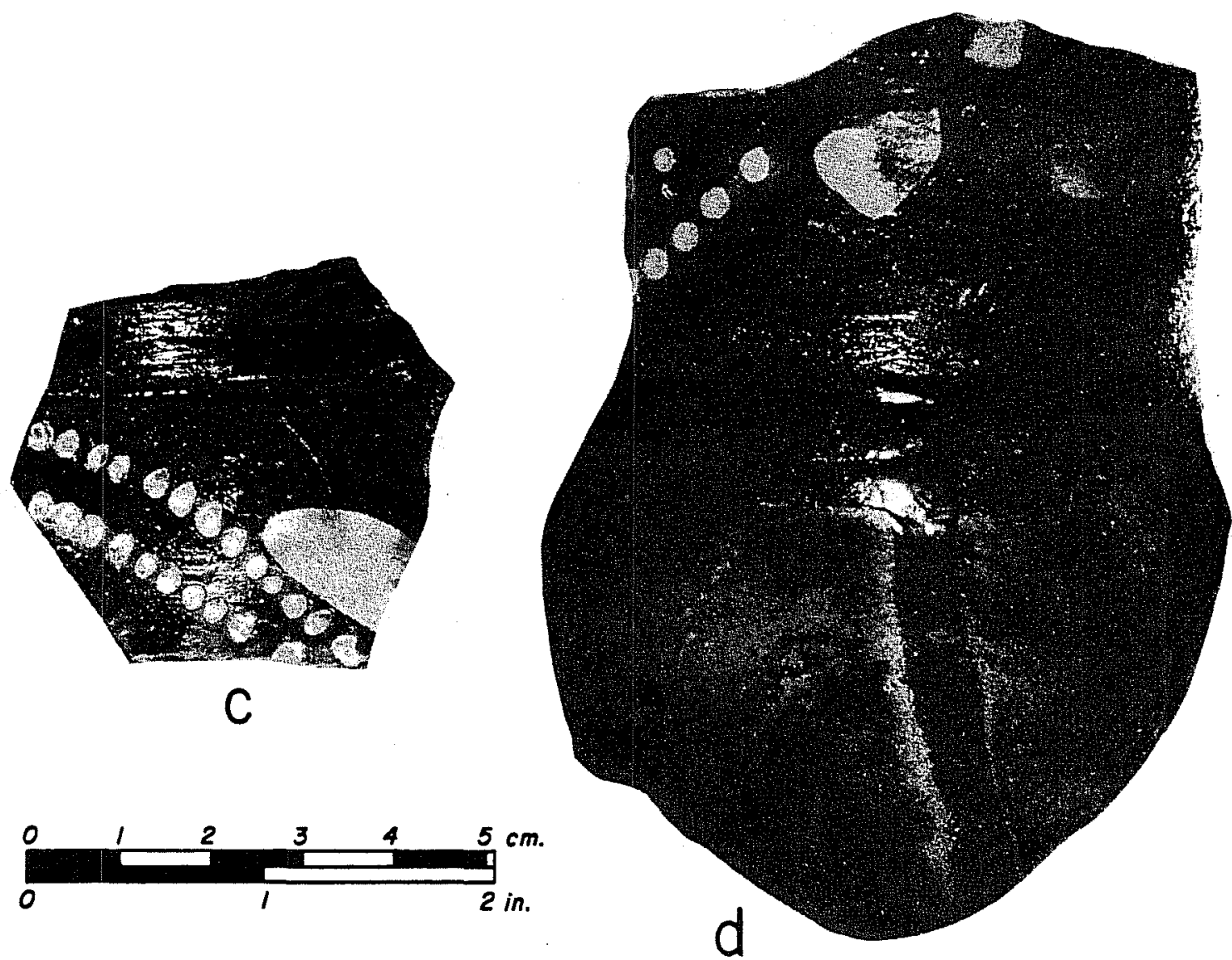

Figure 35. Lead-Glazed Earthenware Sherds from Two Different "Chocolatera" Vessels. a, rim sherd showing design; b, neck sherd containing handle attachment; $c$, neck sherd; $d$, neck and upper body sherd. 
TABLE 5. SUMMARY OF INFORMATION ON REFINED EARTHENWARES FROM 41 BX 677

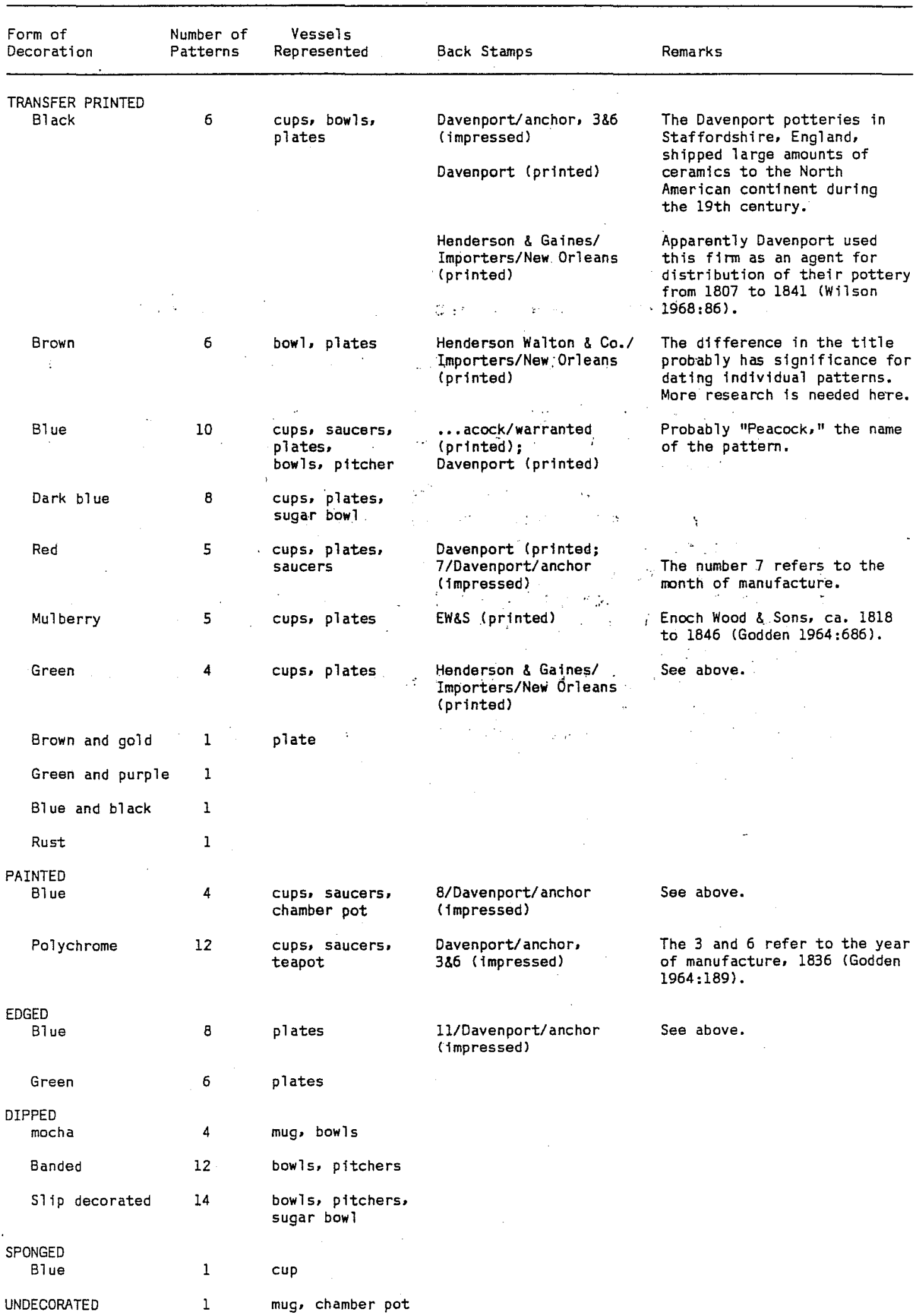




\section{Figure 36. Refined Earthenwares (Banded S1 ip and Mocha).}

a, worm pattern on gold background, body sherd from a serving bow 7 ;

b, blue, green, and brown on white rim sherd from a teacup;

c, cat's-eye (gray and white) on black background, rim sherd from a serving bow1;

d, black (paral1el) and brown (wavy) on white banded slip decoration, rim sherd from a serving bow 1 ;

e, combed decorative technique, black, brown, and white, body sherd from a pitcher;

$f$, worm pattern on black background, body sherd from a pitcher;

$g$, mocha pattern, black on orange, rim sherd from a cylindrical drinking vessel;

$h$, worm pattern on gray with green edge-decorated rim, rim sherd from a serving bow 1 ;

$i$, worm pattern on 1 ight green background, body sherd from a serving bow 1 . 

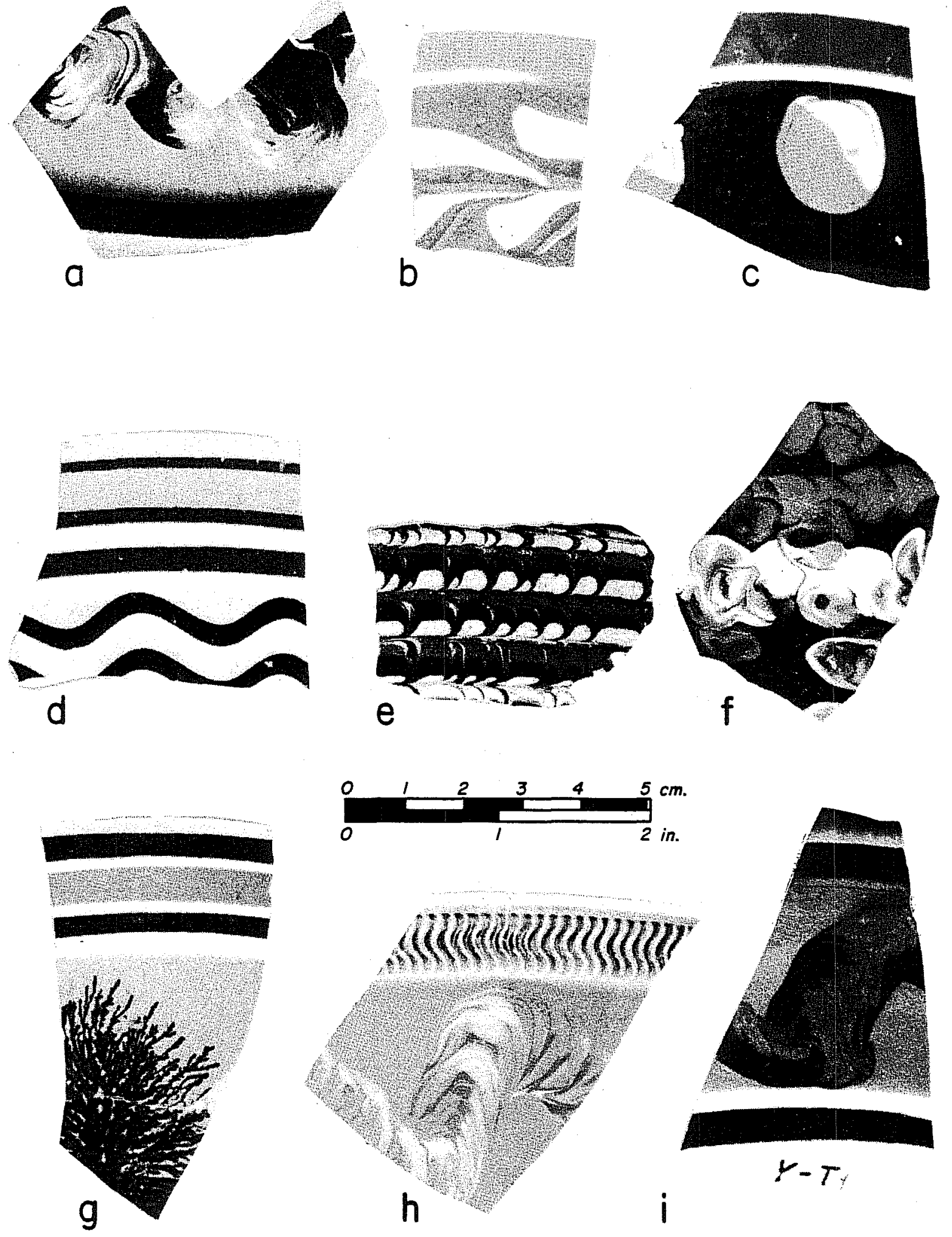

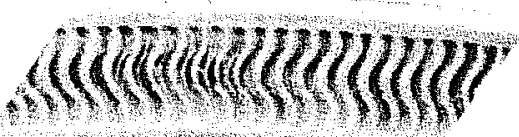

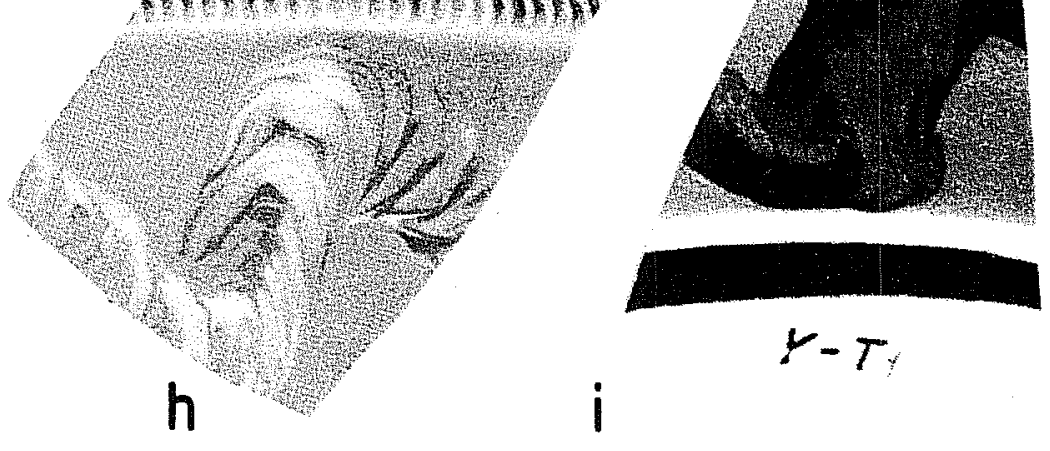


Figure 37. Lusterwares and Refined Earthenwares (Transfer-Printed Pear7wares).

a, copper 1 uster on white background, body sherd from a cup or sma11 pitcher;

b. copper luster, and red transfer-printed sherd from a vesse 1 of unknown shape;

c, pink luster on porcelain, basal sherd from a saucer;

d. purple transfer-printed pearlware rim sherd from a plate;

e, red transfer-printed pearlware rim sherd from a plate;

f, black transfer-printed pearlware rim sherd from a plate;

$g$, brown transfer-printed pearlware rim sherd from a plate. 

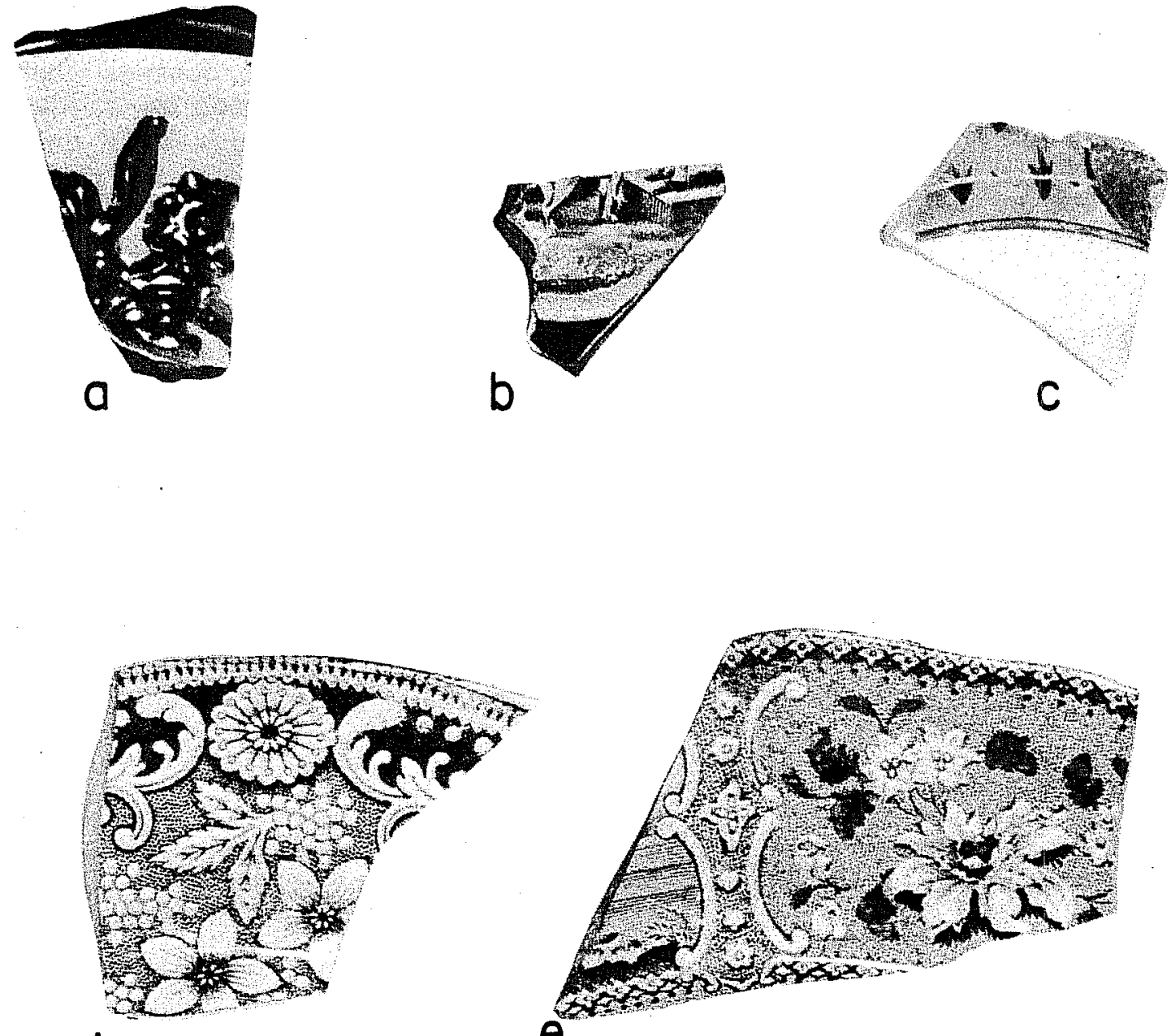

d

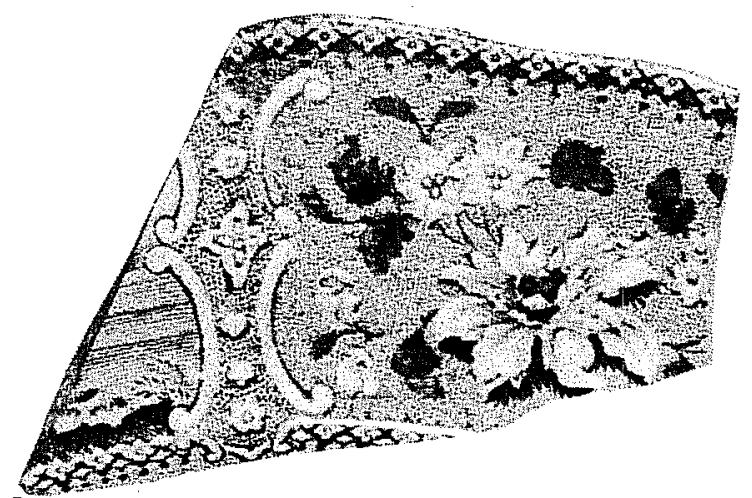

e
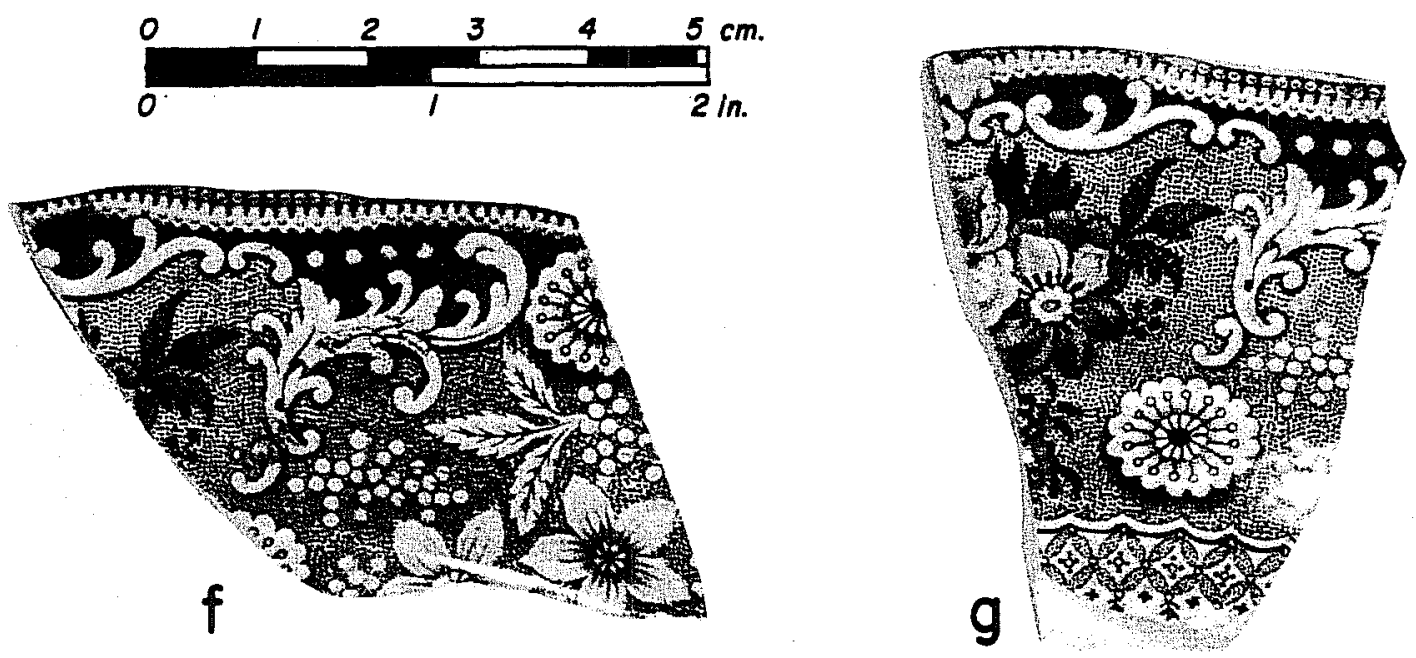
five excavation units examined for this report. Numerous additional patterns and types have been noted in a cursory examination of the remainder of the collection. Descriptions of the different decorative processes used can be found in most books on antique china and are not included here. A general impression of the various patterns can be seen in Figures 36 and $37, d-g$. Undecorated sherds include both totally plain vessels and undecorated fragments of decorated vesse 1s. Many of these sherds, for example, are from edged ware plates (Fig. 38) which bear decoration only around the rim.

LUSTERWARES (Fig. $37, a-c)$

Lusterware is separated from the refined earthenware sherd group because of its unique glaze treatment, in which various metals are added to the glaze to create a lustrous effect. This is used on a variety of fabrics, including refined earthenware, porcelain, and a we11-fired, red body. Four different patterns of pink luster in this group are found on earthenware cups and saucers. Silver luster on earthenware is represented by two patterns. Copper luster is found on as many as five patterns of red bodied pitchers (Fig. 37,a,b). Several patterns of pink 1 uster appear on porcelain sherds (Fig. $37, c)$.

YELLOW WARE (not pictured)

Yel 1 ow ware has a creamy yel 10 paste and a clear or mottled brown glaze. Sherds recovered of this type are too few and small to identify as to shape.

PORCELAIN (not pictured)

Comparatively few porcelain sherds are present in this collection, other than those described under 1usterware. A few porcelain sherds have hand-painted designs over the glaze. A11 appear to be from a cup and saucer.

\section{OBSERVATIONS}

The sherd totals in Table 3 demonstrate the dominance in the collection of imported English ceramics. The number of back stamps which can be confidently dated to the period from 1830 to 1850 would seem to securely position this collection during that time period (Fig. 39,a-i). We know that the popularity of bright 1 y decorated wares waned rapidly starting in 1850 (Mil 1er 1980:18) with the introduction of plain white ironstone and granite wares. The fact that no sherds of these wares were present suggests that the collection is not 1 ater than that date. The presence of a sma11 percentage of 1 ocal and Mexican wares could either represent an earlier occupation in the general area, or the survival of some of these wares in the households involved. The lead-glazed wares were available as early as 1750, but continued in use local1y into the 19th century.

One explanation for the presence of earlier wares in the site deposits hinges on the method of deposition of the trench fil1. Table 4 and Figure 32 


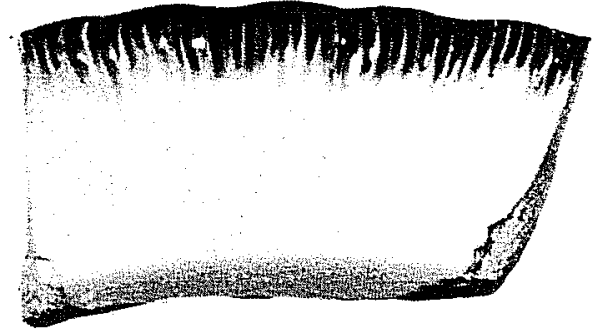

a

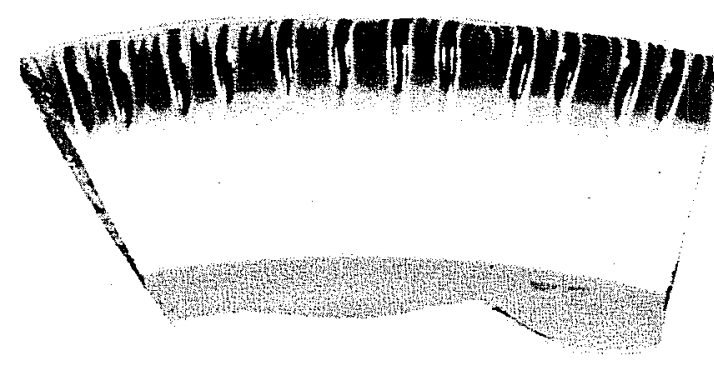

C

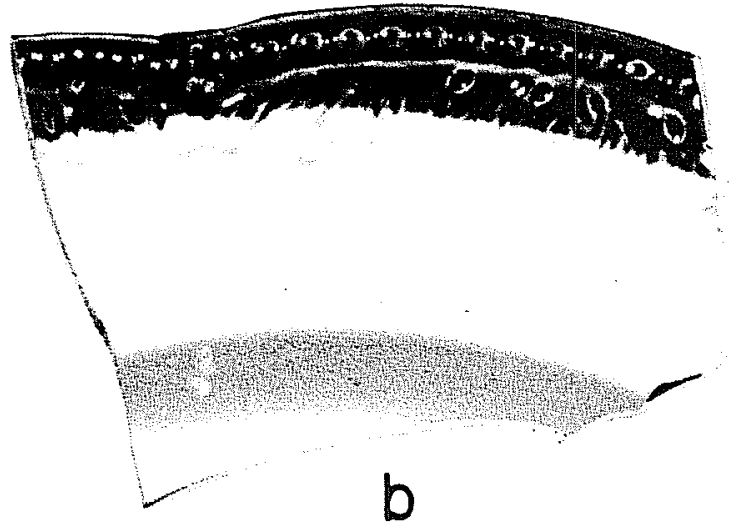

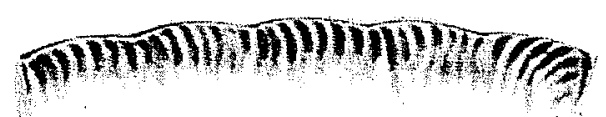

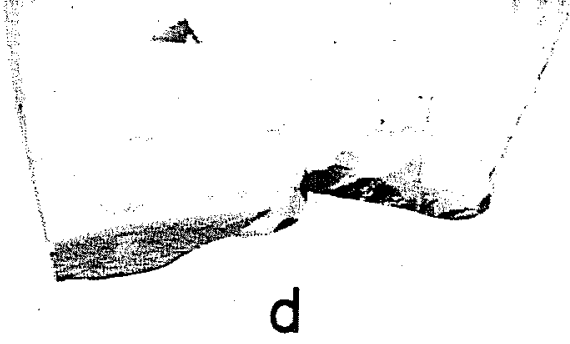

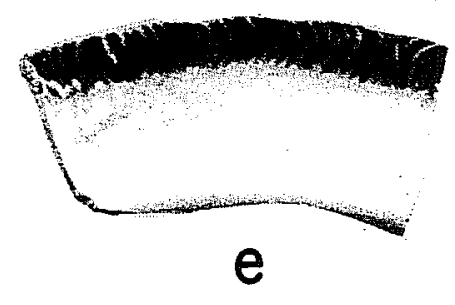
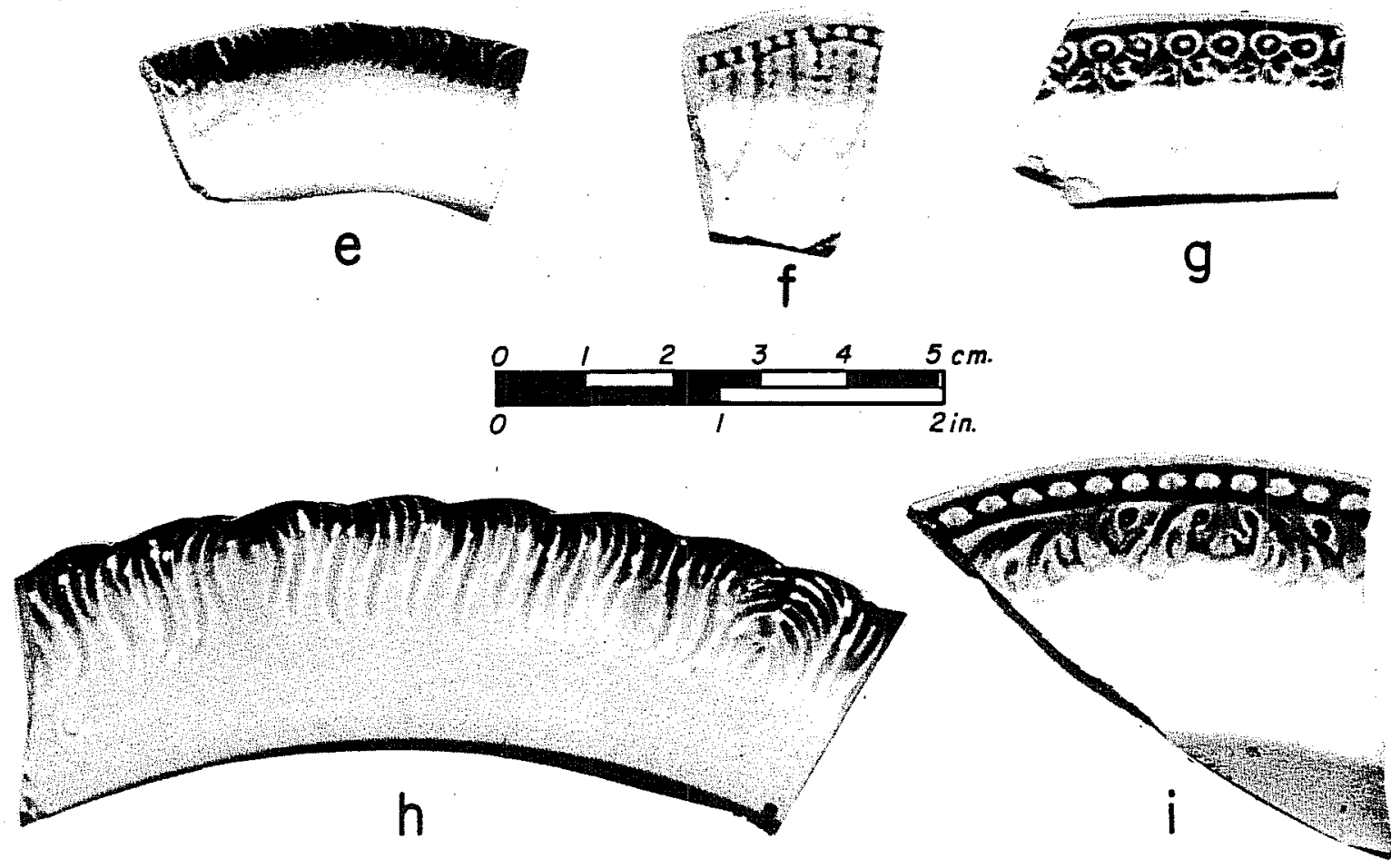

Figure 38. Range and Variation in Edge-Decorated Davenport Plates. ae.g, $i$, blue feather edged decorated rim sherd from a plate; $f$, blue feather edged decorated rim sherd from a saucer; $h$, blue feather edged decorated rim sherd from a platter. 
Figure 39. Back Stamps and Importers' Marks Which Date from 1830 to 1850 .

a, basal sherd from a saucer with "EGYPTIAN, J.H. \& CO" stamped in brown print;

b, basal sherd from a dinner plate with "DAVENPORT" impressed;

c, basal sherd from a dinner plate with "JACKSON, WARRANTED" impressed;

d, basal sherd from a dinner plate with "HENDERSON . . NEW ORLEANS" stamped in black print;

e, basal sherd from a dinner plate with "DAVENPORT" impressed and stamped in black print;

$f$, basal sherd from a dinner plate with "HENDERSON \& GAINES, IMPORTERS, NEW ORLEANS" stamped in green print;

$g$, basal sherd from a dinner plate with "FRENCH GROUPS, DAVENPORT" stamped in blue print;

h, basal sherd from a teacup with "RUINS, DAVENPORT" stamped in black print;

$i$, basal sherd from a dinner plate with "HENDERSON WALTON, \& CO., IMPORTERS, . . ORLEANS" stamped in brown print.

A11 back stamps are on refined earthenware sherds. 

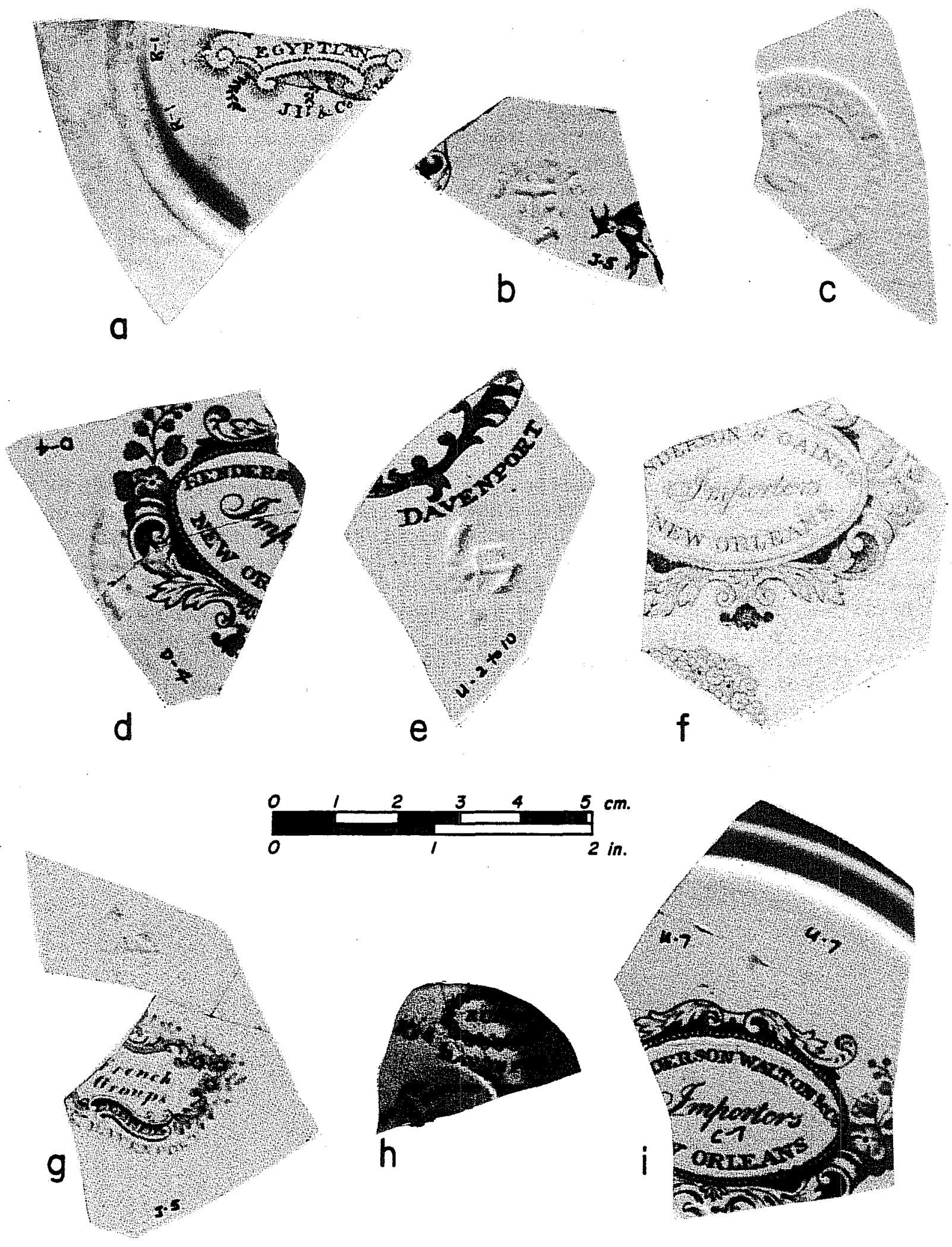
demonstrate the totally random distribution of sherds from the same vessel, as firmly established by cross-mending. Pieces of the same object were found to be widely separated both horizontally and vertically within the deposits. This would not have been the case if discrete deposits of household trash had been thrown into the trench. on an intermittent basis. The most logical explanation for such distribution would seem to be that the trench fill was secondary deposition of trash from another dumping spot nearby. On the basis of this reasoning, it seems probable that the trench was filled by scraping up the accumulated back yard trash from neighboring areas and fili ing the unwanted cavity in preparation for construction of a building on the site. This could also account for the large variety of patterns and vessel shapes present in the collection, which one would hardly expect to come from a single household. A collection of sherds from 19th-century occupation at Mission San Juan Capistrano, representing the trash from more than 10 families, contains much the same volume and variety (Schuetz 1969:8-22).

\section{CONCLUSIONS}

Preliminary examination and analysis of a ceramics sample from site 41 BX 677 have yielded important information regarding the origin and deposition of the fill in the trench. The analysis has demonstrated that the site has a great deal of potential for obtaining a valuable body of information on the 1 ife of the citizens of $L a V i 11$ ita and San Antonio during the 1830 to 1850 period. In addition, the unusually large and varied collection of ceramics presents possibilities for detailed analysis of forms and patterns of early 19 thcentury ceramics seldom encountered in Texas archaeological sites. Research generated from this important collection will influence ceramic analysis in Texas in numerous ways for some time to come. 


\section{REFERENCES CITED}

Godden, G. A.

1964 Encyclopaedia of British Pottery and Porcelain Marks. Bonanza Books, New York.

Ivey, J. E. and A. A. Fox

1981 Archaeological Survey and Testing at Rancho de 1 as Cabras, Wilson County, Texas. Center for Archaeological Research, The University of Texas at San Antonio. Archaeological Survey Report 104.

Milier, G.

1980 Classification and Economic Scaling of 19th Century Ceramics. Historical Archaeology 14:1-19.

Schuetz, M. K.

1969 The History and Árcheology of Mission San Juan Capistrano, San Antonio, Texas, Vol. II. State Building Commission Archeological Program Report 11.

Wilson, M. L.

1968 Two Historic Burials in the Three Forks Locale. Bulletin of the 0k1 ahoma Anthropologica1 Society. XVII:75-86. 


\title{
CHAPTER 6 \\ PRELIMINARY ANALYSIS OF FAUNAL REMAINS
}

\author{
Alisa J. Winkler
}

\section{INTRODUCTION}

Among the many artifacts recovered from La Villita Earthworks is a tremendous quantity of animal bones.. Recovered from Units C and D (Fig. 40) were 1398 bones identifiable to taxon and element and 3986 bone fragments. Most of the bones are broken; breakage occurred during butchering, deposition, and excavation. Many of the remains show evidence of butchering, including knife cuts, chop marks, and saw marks. Some bones have been chewed and punctured by humans or other animals, or gnawed by rodents.

Almost all the bones recovered are the remains of domestic animals, with cow (Bos taurus) comprising the bulk of the sample (Table 6). Other domestic animals from the site include horse (Equus caballus), pig (Sus scrofa), cat (Fel is domesticus), goat or sheep (Capra sp. or Ovis sp.), and possibly donkey (Equus asinus), dog (Canis familiaris), and chicken (Gallus gallus). The remains of wild animals include white-tailed deer (Odocoileus virginianus), striped skunk (Mephitis mephitis), possibly cottontail rabbit (Sylvilagus sp.), an unidentified small rodent, a small bird (possibly the meadow 1 ark. Sturnella sp.), turtle or tortoise, frog or toad, and gar (Lepisosteus sp.).

As mentioned in Chapter 3 , the Parapet Fill and the Villita Fill form distinct stratigraphic units. The taxa in these two fills are similar (i.e., cow, horse, pig) and may represent the remains of the same individuals. The sma 11 sample size from the Parapet Fill prevents the use of statistical tests to look for differences between the two fills. These two units will be considered as one deposit in this chapter.

\section{METHODS}

For this preliminary report, only materials from Units $C$ and D were examined. These units were chosen because excavation extended down through the basal Parapet Fil1. Bones were given to the author after they had been washed and separated by unit, leve1, and bag number. Bone cross-matches were found between different levels and different bags within one level, an indication that these divisions were arbitrary. Since the unit divisions were set up as an arbitrary grid system, cross-matches between units are expected. Dry screening was performed in the field with a 1/4-inch mesh. This large mesh size probably accounts for the paucity of small mammal remains (i.e., shrews, mice) which could easily pass through the screen.

Bones and bone fragments were sorted by skeletal element and by the body side. Postcranial elements of juvenile mammals were distinguished from adults by the degree of epiphyseal fusion. The maxillae, mandibles, and isolated teeth of juveniles were distinguished from those of adults by the amount of tooth wear, presence or absence of deciduous dentition, and eruption of adult dentition. A detailed description of the age structure of 

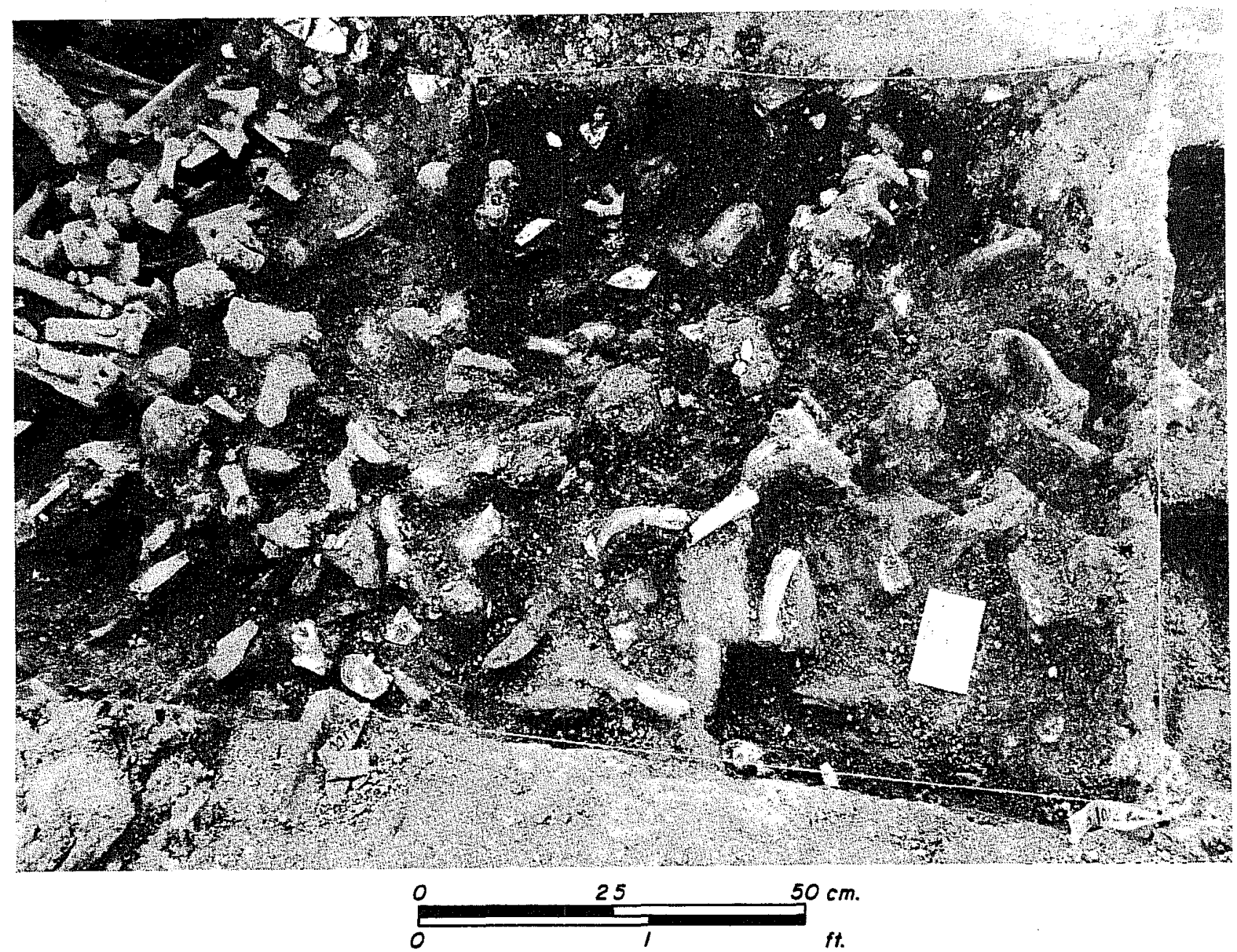

Figure 40. Partial 1 y Excavated Bone Bed in Excavation Units C and D at La Villita Earthworks.

the fauna and any indications of seasonality will be included in the final report.

Evidence of human modification, including butchering, tool making, and burning, was recorded, in addition to the type of modification and where on the bone it occurred. Spiral fractures, chewed bone, gnawing striations, and tooth punctures were recorded as observed.

Specimens were identified to the lowest taxonomic level possible using comparative collections of recent osteological remains housed at The University of Texas at Austin, Texas Memorial Museum, Laboratory of Vertebrate Paleontology, and Texas Natural History Laboratory. Fish (except the gar scale), amphibian, and reptile materials have not yet been identified 
TABLE 6. FAUNAL LIST AND SPECIMEN INFORMATION

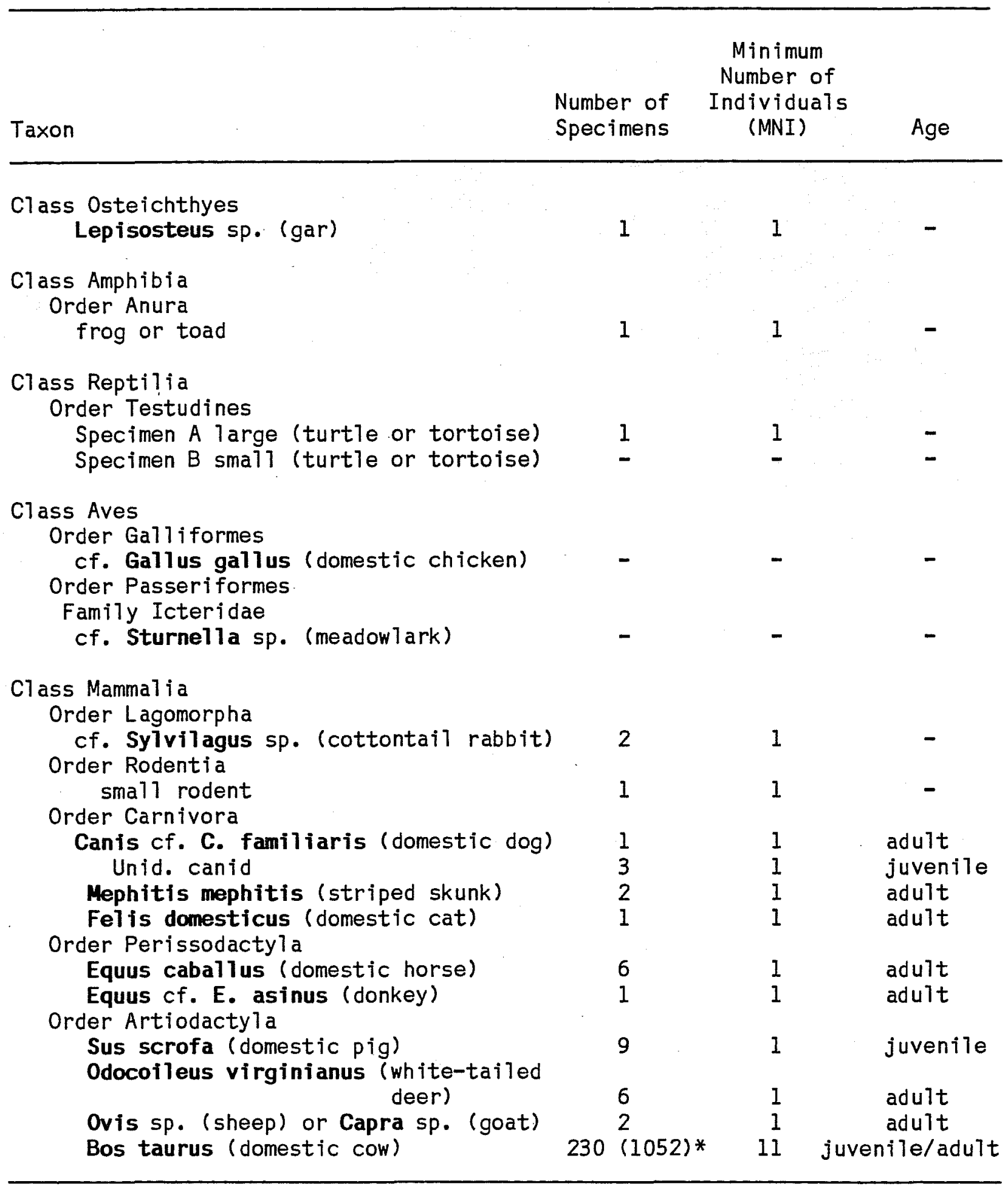

*Probably referable to Bos (see text) 
to species, and identification of the bird remains is not complete. Faunal remains from La Villita Earthworks will be permanently housed at the Center for Archaeological Research. The University of Texas at San Antonio.

\section{DESCRIPTION OF TAXA}

Eleven taxa of mammals, at least two of birds and turtles (or tortoises), and at least one fish and frog or toad are identified in this preliminary study. Table 6 indicates the number of specimens of each taxon, the minimum number of individuals (MNI), and the approximate age of those individuals. Computation of MNI for each taxon was based on the maximum number of unique skeletal elements (i.e., Bos taurus, left astragalus) in the sample.

Bovid remains from this site are probably those of the domestic cow (Bos taurus) and not bison (Bison bison) because of their relatively small size and the 1 ack of any osteological characters definitely indicating Bison, such as very long neural spines on the thoracic vertebrae. Bos remains are the most common remains from this site, both in number of specimens (minimum of 230) and in MNI (11). While many bone fragments could be assigned either to Bos or Equus based on similar morphology, the much greater number of identifiable elements attributable to Bos suggests that they belong to this taxon (Tables 6 and 7). Many of the bones are from juvenile anima 75 . The majority of butchered specimens from this site are assignable to this taxon.

So far, little material referable to sheep (Ovis sp.) or goat (Capra sp.) has been identified (Fig. $41, d)$. The bones of these animals are very simi 1 ar, and it is often difficult to distinguish between them. It is also difficult to distinguish the bones of these taxa from some of the bones of a sma 11 white-tailed deer. Since both sheep and goat may be present in this sample, and since the sample size is so small, specific identification will not be made until all the material has been examined.

There are a few bones of the domestic pig (Sus scrofa). Several of these are from juveniles, and one shows evidence of butchering (Fig. 4l,a).

Horse (Equus cabal1us) and possibly donkey (Equus asinus) remains are rare from this site. No material definitely assignable to Equus is butchered. Separation of the osteological remains of a small horse from those of a donkey is essentially impossible except for the lower molars. In the lower molars of a donkey the ectoflexid does not extend into the isthmus while in the lower molars of a horse it does. It should be noted that the degree of penetration of the ectoflexid may be modified by tooth wear. This is a difficult character to use for isolated cheek teeth because it is difficult to distinguish between $\mathrm{p} 3$ ( $\mathrm{p}=1$ ower premolar), p4, ml ( $\mathrm{m}=1$ ower molar), and $\mathrm{m} 2$. This character applies only to the lower molars. Most of the horse remains from this fauna are referable to Equus caballus because of their large size. One heavily worn, isolated 1 ower cheek tooth (either p3, p4, ml, or m2) may be referable to Equus asinus because of its smal1 size.

Several antier fragments are from the white-tailed deer, odocoileus virginianus. Antlers of this species 1 ack the repeated dichotomous branching found in antler of the mule deer, Odocoileus hemionus (Kurten and Anderson 
TABLE 7. SKELETAL COMPOSITION OF BOS, INCLUDING PROBABLE BOS (BOS/EQUUS) REMAINS, WITH PERCENTAGE BURNED AND BUTCHERED

\begin{tabular}{|c|c|c|c|c|c|}
\hline Element & $\begin{array}{l}\text { Number of } \\
\text { Specimens }\end{array}$ & $\begin{array}{l}\text { Number } \\
\text { Burned }\end{array}$ & $\begin{array}{c}\text { Percentage } \\
\text { Burned }\end{array}$ & $\begin{array}{l}\text { Number } \\
\text { Butchered }\end{array}$ & $\begin{array}{l}\text { Percentage } \\
\text { Butchered }\end{array}$ \\
\hline $\begin{array}{l}\text { Vertebra fragments } \\
\text { Bos } \\
\text { Bos/Equus }\end{array}$ & $\begin{array}{r}33 \\
332\end{array}$ & $\overline{5}$ & - & $\begin{array}{r}14 \\
111\end{array}$ & $\begin{array}{l}42.4 \\
33.4\end{array}$ \\
\hline Sacra & 4 & - & - & 3 & 75.0 \\
\hline $\begin{array}{l}\text { Limb fragments } \\
\text { Bos } \\
\text { Bos/Equus }\end{array}$ & $\begin{array}{r}59 \\
164\end{array}$ & $\begin{array}{r}7 \\
19\end{array}$ & $\begin{array}{l}11.9 \\
11.6\end{array}$ & $\begin{array}{l}15 \\
25\end{array}$ & $\begin{array}{l}25.4 \\
15.2\end{array}$ \\
\hline $\begin{array}{l}\text { Rib fragments } \\
\text { Bos/Equus shafts } \\
\text { Bos/Equus heads }\end{array}$ & $\begin{array}{r}294 \\
32\end{array}$ & $\begin{array}{l}15 \\
-\end{array}$ & 5.1 & $\begin{array}{r}152 \\
20\end{array}$ & $\begin{array}{l}51.7 \\
62.5\end{array}$ \\
\hline $\begin{array}{l}\text { Pelvic fragments } \\
\text { Bos } \\
\text { Bos/Equus }\end{array}$ & $\begin{array}{l}39 \\
19\end{array}$ & $\begin{array}{l}2 \\
2\end{array}$ & $\begin{array}{r}5.1 \\
10.5\end{array}$ & $\begin{array}{r}33 \\
7\end{array}$ & $\begin{array}{l}84.6 \\
36.8\end{array}$ \\
\hline Mandibles & 2 & - & - & 2 & 100.0 \\
\hline Maxilla fragments & 1 & 1 & 100.0 & 1 & 100.0 \\
\hline $\begin{array}{l}\text { Isolated teeth and } \\
\text { maxilla/mandible } \\
\text { fragments }\end{array}$ & 8 & - & - & - & - \\
\hline Phal anges & 28 & - & - & - & - \\
\hline Calcanei & 4 & - & - & 1 & 25.0 \\
\hline Astragal i & 12 & - & - & 1 & 8.3 \\
\hline Patel 1 ae & 4 & - & - & - & - \\
\hline $\begin{array}{l}\text { Styloid process of } \\
\text { fibulae }\end{array}$ & 3 & - & - & - & - \\
\hline Carpals/Tarsals & 8 & 3 & 37.5 & 1 & 12.5 \\
\hline Sesmoids & 4 & - & - & - & - \\
\hline Horn Cores & $2(?)$ & $I(?)$ & 50.0 & 1 & 50.0 \\
\hline
\end{tabular}


1980:310-311). Mule deer al so tend to be slightly 1 arger and more robust than white-tailed deer, but the two overlap in size and are osteologically inseparable except for the antlers. At present, the white-tailed deer is known from Bexar County, but the mule deer is not. In Texas, the mule deer is currently restricted to the Trans-Pecos area and some parts of the High Plains (Davis 1974:254-259).

The remains of three carnivores are represented in this faunal collection. These are the domestic cat (Felis domesticus, Fig. 4l,c), the striped skunk (Mephitis mephitis, Fig. 4l,e), and possibly the domestic dog (Canjs familiaris, Fig. 4l,b). The on 1 y cat material is a fragment of a maxilla, including P3 ( $P=$ upper premolar). A canid incisor is 1 arger than a coyote and is comparable in size to that of a large dog. Several juvenile canid vertebrae could be referred to as either domestic dog or coyote based on size. The 1 arge incisor and small vertebrae belonged to different individuals. The osteological remains of domestic dogs and coyotes are difficult to separate, especially since the two may interbreed. Gilbert (1980:66) lists skul1 characters as useful in the separation of these two taxa. He suggests using a suite of characters for identification.

A butchered and punctured innominate and fragment of a scapula are referable to the striped skunk (Mephitis mephitis; Fig. 4l,e). The striped skunk is common in this area today (Davis 1974).

Smal 1 mammal remains consist of a fragment of a scapula and a metapodial that probably belonged to a cottontail rabbit (Sylvilagus sp.). This animal may have been used for food. The small rodent incisor is not identifiable further.

\section{BUTCHERING PATTERNS}

Many bones from La Villita Earthworks show evidence of butchering; $25.4 \%$ of the taxonomically identified bones and $10.0 \%$ of the unidentified bones are butchered. Butcher marks consist of knife cuts visible as shallow scratches (Fig. 4l,e) and axe or hatchet chops visible as deep cuts, sometimes wedgeshaped and/or causing local crushing of the bone (Fig. 42,b, c, and d). Saw marks are often visible as an extensive smooth or striated surface. Saw nicks may be observed, and sometimes the cut appears polished (Fig. $42, a$ ).

Beef was apparently the meat of choice as shown by the 1 arge MNI of cows compared to other taxa (Table 6). Many of the Bos remains are butchered, 31.3\% specifical7y identified as Bos and 36.8\% identified as Bos/Equus. Most of the butchered bones are vertebrae (often juveniles), sacra (often juveniles), ribs, 1 imbs, and pelvic bones (Table 7). The centra of many vertebrae are cut (sawed?) partly through, and often the zygapophyses and neural spines have chop marks. Knife cuts occur on neural spines, and sometimes the spines have been sawed off or chopped and then broken through. Thoracic and Tumbar vertebrae are common and usually butchered. Cervical and caudal vertebrae are rare, even considering that there are proportionally fewer of them in the whole animal. Few of the cervical and caudal vertebrae are butchered. These bones would produce 1 ittle meat. Sacra are usually partly cut (sawed?) through the centra, and sometimes the zygapophyses are 


\section{Figure 4l. Selected Faunal Remains.}

a, Sus scrofa (juvenile), rt. (=right) mandible with ml, m2, anterior end $\mathrm{m} 3$, anterior is the right, arrow indicates cut/ chop mark $(C-5-1)$;

b, Canis cf. C. familiaris, Lt. (=1eft) upper third incisor (D-31);

c, Felis domesticus, Lt. maxilla with P3, anterior is to the left $(D-1-1)$;

d, Ovis sp. or Capra sp., atlas in dorsal. view, anterior is toward the scale $(C-8-1)$;

e, Mephitis mephitis, Lt. innominate in ventral view, anterior is to the 1eft, arrows indicate knife cuts (to 1 eft) and a puncture (to right) $(\mathrm{C}-5-2)$;

$f$, burned bone aw 7 (C-8-2). 

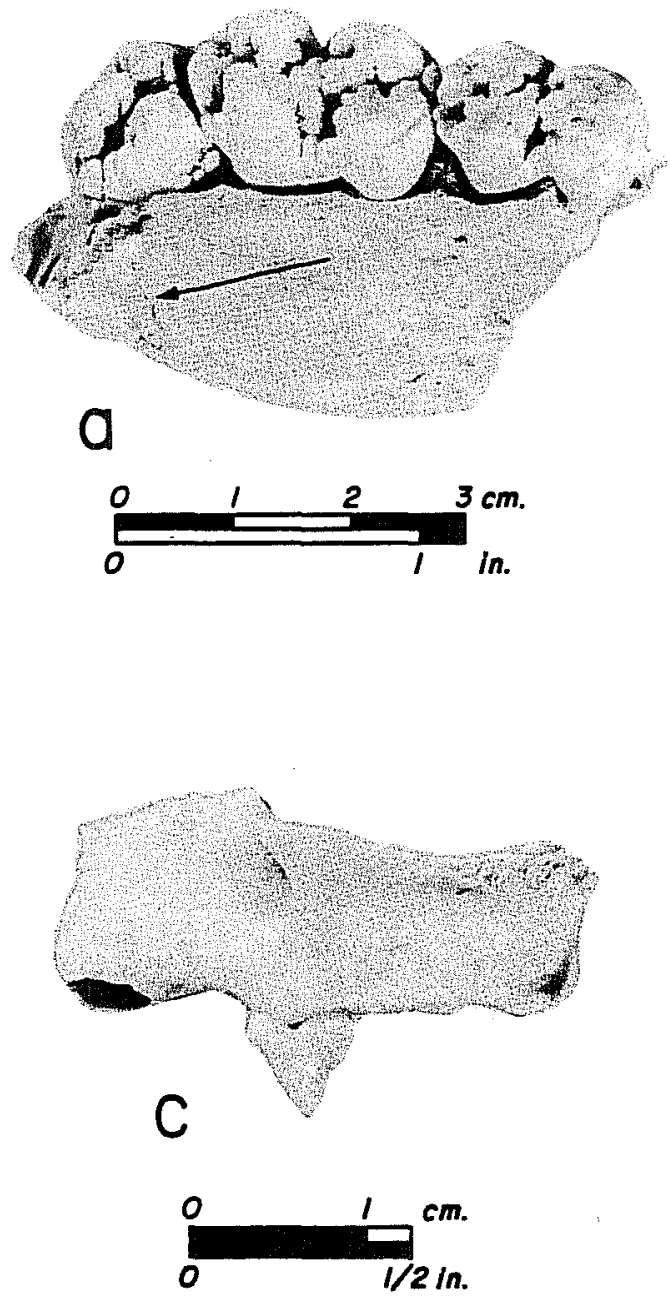

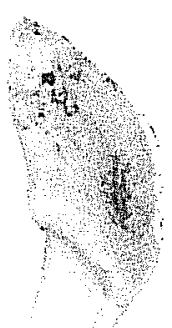

b
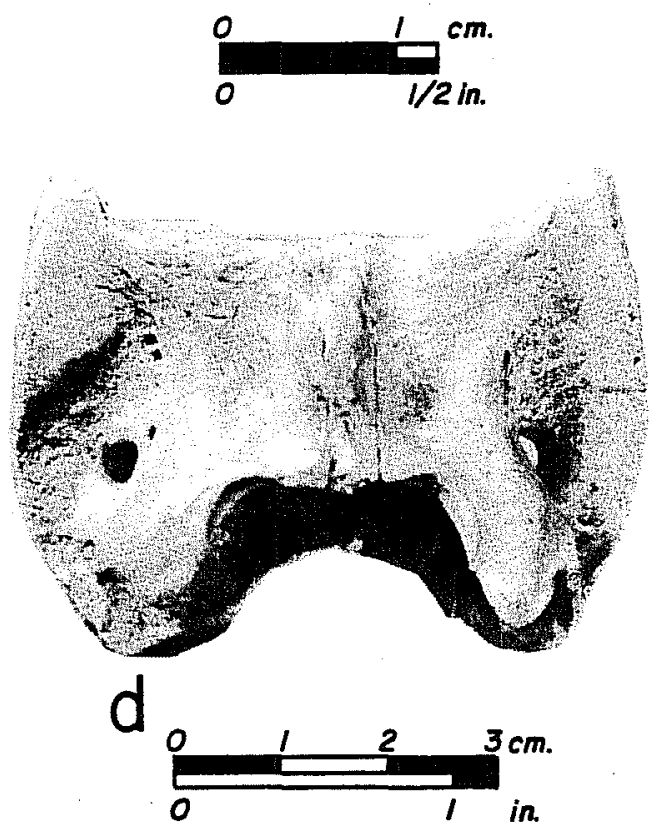
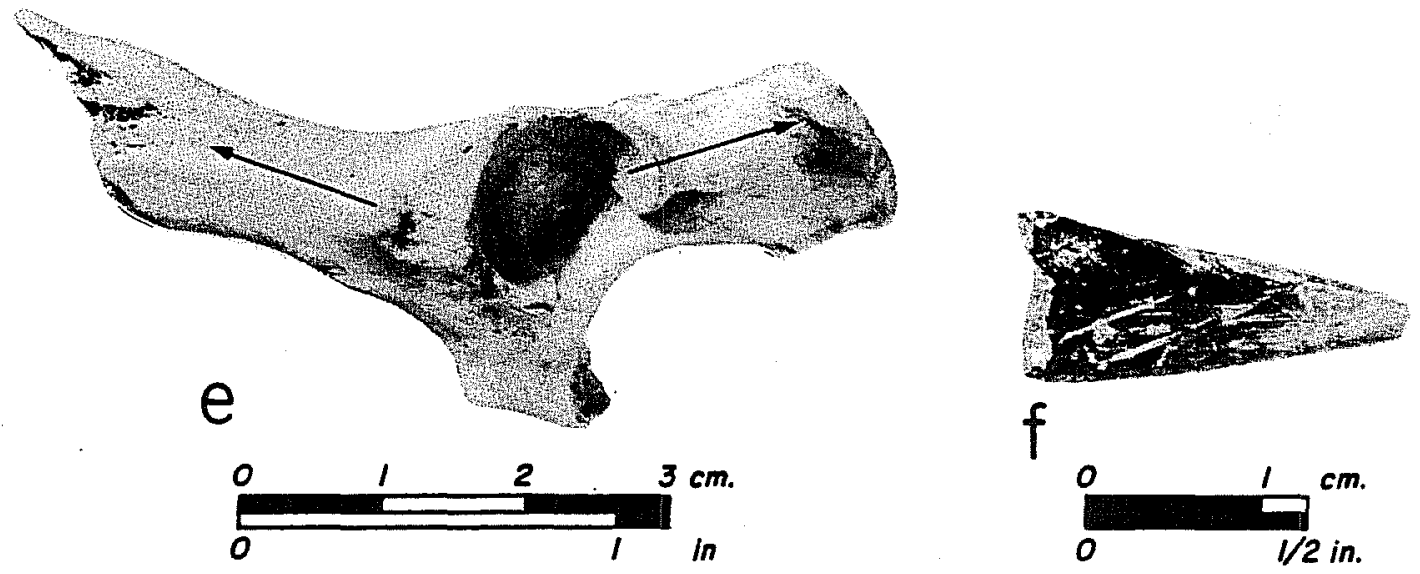

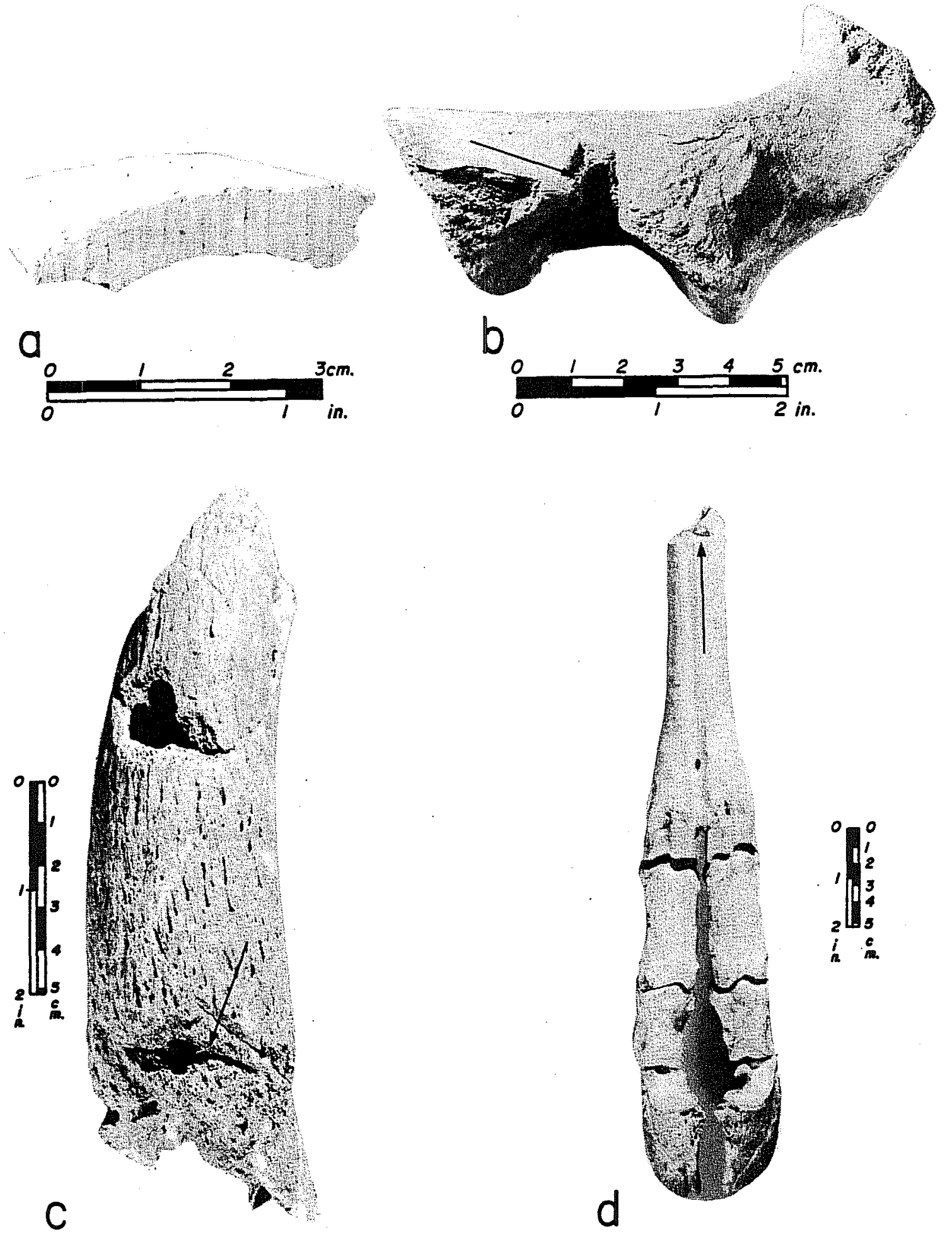

Figure 42. Examples of Butchered Bos taurus Bones. a, sawed femur(?) fragment in cross section $(D-2-1) ; b$, juvenile, Rt. pubis and part of the acetabulum in anteroventra 1 view, arrow indicates a chop mark (D-4-1); $c$, horn core, arrow indicates chop mark (D-Parapet-1); d, articulated Rt. hindleg in anterior view, arrow indicates chop mark (S-3-1). 
partiy cut or chopped. According to Schulz (1979), several of the better cuts of meat (ranked according to 1 ate 19th-/early 20th-century values) would be represented by butchered thoracic, 1 umbar and sacral vertebrae.

There are many 1 arge butchered rib fragments from this site. Most of these butchered ribs are chopped through or are chopped part $7 y$ through and then broken the rest of the way. Short rib fragments, approximately 8 to $10 \mathrm{~cm}$ in length, are common. Knife cuts possibly resulted from removing meat or from cutting tendons during butchering.

The most frequently butchered bones are pelvic fragments. Thirty-three of thirty-nine Bos pelvic bones were sawed and/or chopped, mostly near the acetabulum. Butcher marks near the acetabulum may represent separation of the hind leg from the body by severing the joining between the proximal end of the femur and the acetabulum. Butchered $i 1 i a$ also represent choice cuts of meat (Schulz 1979).

Several 1 imb bones are also butchered. Cuts, chops, and saw marks are often seen at the ends and/or along the shafts of $1 \mathrm{imb}$ bones. Butchering at the ends may represent separation of the $1 \mathrm{imb}$ bones. A femur (or possibly humerus) is sawed into short segments ( $F$ ig. 42,a). Modern-day round steak "0-bones" are cut from the femur. While the butchering technique differs, the inhabitants of La Villita apparently enjoyed basically the same cuts of meat as people do today.

Figure 42,d shows an articulated hindleg of Bos... The proximal end of the metatarsal has been chopped and then broken through. This portion of the leg is usually discarded during the butchering process (Schulz 1979). The break in the metatarsal was probably to separate the unwanted foot from the rest of the carcass. It is noteworthy that there are many foot bones (i.e., phalanges, tarsals/carpals, metapodials) in the total sample, but few of them are butchered. This is consistent with the idea that foot bones were discarded during butchering.

A couple of unusual butchered Bos bones deserve special mention. The first, a horn core (Fig. 42, C), has chop marks near the base of the horn on one side. These may represent removal of the horn sheath. The second, part of the posterior end of the skull, is burned, and sawed through the basioccipital, and has saw and chop marks on the occipital condyle. These butcher marks may reflect removal of the brain for consumption.

The remains of several other taxa are butchered. As mentioned earlier, a fragment of a juvenile Sus scrofa (Fig. 4l,a) has a cut or chop mark, and an acetabulum of Odocoileus virginianus is butchered, probably representing separation of the leg from the body. An unusual butchered bone is the left innominate of Mephitis mephitis (Fig. 4l,e). This bone has knife cuts on the ilium and possibly on the acetabulum which may indicate removal of the leg. Clopper (1909) describes skunks being used for food. Punctures on the bone look too small for human teeth and were probably made by a carnivore after the bone was discarded. The ends of the bone may be chewed; whether this was done by humans or carnivores is unknown. 
It is noteworthy that no bones positively identified as Equus are butchered. The on $1 y$ bone referred to Ovis/Capra is too sma 11 to make any conclusions about whether or not these animals were butchered.

\section{BONE TOOLS}

Several bone tools, mostly of unknown purpose, were found. One of these is a burned bone aw1 ( $F$ ig. 41,f) made from a 1 arge mammal rib fragment. Another, the proximal end of a Bos metatarsal, was shaped and polished possibly from use, into a roughly spatulate shape.

Two types of bone tools made from Odocoileus remains were found. These are the smoothed and polished, spirally fractured distal end of a tibia, and the sharp tips of several antler fragments that are polished to varying degrees. These tools, and possibly the bone aw 1, may have a prehistoric origin, as wel1 as several other artifacts mentioned in Chapter 3.

\section{DISCUSSION AND CONCLUSIONS}

Preliminary analysis of Units $C$ and $D$ at La Villita Earthworks has yie lded a large number of bones, primarily of domestic animals, especially cow. Burned bone is fairly common from the site, including $7.2 \%$ of the taxonomically identified bone and $13.8 \%$ of the unidentified bone. There is no distinctive pattern reflected in the burned bones, except that most are fragments. Concentrations of burned bone were noted in Units $C$ and $D$ near the top of the section (Levels $C-1$ to $C-3$ and $D-2$ to $D-4$ ), and especially in Levels 8 and 9 of both units. The diverse nature of the burned material suggests that bone trash was burned in mass.

Many of the bones from this site show evidence of butchering in the form of knife cuts and chop marks. Bos bones from the site indicate that many different cuts of meat were used, including the choicest cuts. Waste products of the butchering process (e.g., cow feet) are al so present. This suggests that the fill was a trash area for both table remains and refuse from the butchering process.

A detailed analysis of ethnicity has been postponed until the entire sample has been studied. So far, however, the butchered remains suggest a butchering process with many differences from what would be observed in a modern Anglo-American butcher shop. 


\section{REFERENCES CITED}

Beaver, B.

1980 Comparative Anätomy of Domestic Animals. The Iowa State University Press, Ames.

Clopper, J. C.

1909 J. C. Clopper's Journal and Book of Memoranda for 1828. Texas Historical Association Quarterly 13(1):77.

Davis, W. B.

1974 The Mamma 15 of Texas. Texas Parks and Wildi ife, Bulletin 41. Austin, Texas.

Gilbert, B. M.

1980 Mammalian 0steology. Privately printed, Laramie, Wyoming.

Kurten, B. and E. Anderson

1980 Pleistocene Mammals of North America. Columbia University Press, New York.

Schu1z, P. D.

1979 Historical Faunal Remains from Panamint City: Notes on Diet and Status in a California Boom Town. Pacific Coast Archaeology Quarterly 15(4):55-64. 


\title{
CHAPTER 7 \\ GLASS ARTIFACTS
}

\author{
David D. Turner
}

\section{INTRODUCTION}

The primary goal in analyzing the glass materials recovered from site 41 BX 677 was to verify recognized technological procedures with chronology. The recognizable signs of manufacturing technology were assessed against the available literature on 19th-century glassmaking techniques. The materials found support dating the site from the 1830 s to the 1850 s.

Glass production in the early 19th century was undergoing a period of innovation and development, and numerous techniques were available to producers of manufactured items. Invention was rapid, and competition was fierce. In the early industrial period, production was seasonal. Most factories were closed at least three months out of the year. Glassmakers shut down for the summer, usual1y Ju1y through September, as 1 ate as 1903 (I1 1 inois G1ass Co. 1903-1904:4).

The glass materials were washed, catalogued, and bagged by color. Color can provide some insight into the chemical content of the glass, but little else in the way of identifying production technique. In the laboratory, further categorization was carried out based on identifiable vessel elements, such as bottle bases and necks; these were called diagnostics. The 1 anguage used to define the articles and to describe their attributes was derived from reputable principal dating sources such as Kendrick (1967), Jones (1971), Newman (1970), Lorrain (1968), and Miller and Sul1ivan (1981).

\section{BACKGROUND}

The most common type of vessel in the early 19th century was the free-blown vessel. These vessels often show flaws which are internal, such as bubbles, striations, and varying thicknesses. Bases of vessels, especially bottles, will show a pontil scar, a circular raw area of broken glass. Bare iron pontils were popular until the 1840s. The improved varieties of empontilling techniques were developed in the early 1840 s and became very popular. In this collection, the improved process was recognized on only one basal fragment (discussed 1 ater).

In 1810, a two-piece hinge mold process was introduced. The two-piece mold shaped the base and neck, but the mouth and 1 ip had to be hand-finished. This required removing the bottle from the mold by the use of a pontil rod. Mold seams and pontil scars will be visible on two-piece, blown-in-mold items. The three-piece mold process, popularized from 1820 to 1821 , $1 \mathrm{eft}$ mold seams 1 ateraliy around the shoulder and vertically up the neck of glass vessels. The seams disappear at the collar due to the reheating and finishing of the $1 \mathrm{ip}$ and mouth. Three-piece mold processes also were handfinished. 
The pressing device was developed in 1827. This al lowed for 1ess skil 1ed 1 aborers to produce vessels which looked 1 ike expensive craft wares. The purpose of the pressing machine was to reduce the expense of "fancy" tablewares (Putnam 1968:69-80; Lorrain 1968:38). Colored wares, especial1y blue patterned dishes called "1 acy wares," were produced up to 1850. Several fragments of this type of ware, representing at least two vesse1s, were recognized in the collection. The peak of popularity of this ware was 1845. After 1850, the popularity of this ware rapidly diminished (Chambers 1847:118-119; Drew 1950; Lorrain 1968:39-40).

The turn or paste mold process of bottle-making was essentially a variation of the blown-in-mold (BIM) method. The object was hand-blown in the mold and then turned while still inside. The rotation of the vessel inside the mold eliminated the mold seams and the pebbly or hammered surface texture of molded items (Kendrick 1966:43; Lorrain 1968:38). Some turn/paste items wi11 show pontil scars on the bases, but the method characteristics are usually obscured. The "paste" in the term "turn/paste mold" refers to a lubricating agent used to prevent distortion while turning the object. The literature examined so far refers to this process interchangeably as "turn," "turn/ paste," or "paste" molded. Further, the 1 iterature does not reveal what type of 1 ubricant was used. The turn-mold process reached its peak of popularity during the 1860s, but items made by this process were available throughout the 19th century (Kendrick 1966:30).

Bottles and other vessels created by semiautomated and fully automated methods were developed during the 1880s. The Arbogast and Ashley processes were two semiautomated methods designed in the United States in 1881 and in England in 1886, respectively (Miller and Su 1.1 ivan 1981:2-3). Both were involved in 1arge-scale production by 1896 (Lorrain 1968:43). The base of a bottle made by these two processes will show a valve mark that is circular on the base. This mark indicates the valve used to eject the finished vessel from the mold. Kendrick (1966:78-87) reports that valve marks will be found on vessels made in molding devices. Only one valve-marked basal fragment was recognized in this collection. By 1903, the Owens fully automated process was in production. This process, along. with semiautomated processes, made glass containers inexpensive.

Four decorative techniques were recognized in the collection, but these are of minumum value in determining date of manufacture. Nevertheless, they should be noted:

1. Coloring in the chemical mix of the glass.

2. Molding--the BIM methods.

3. Pressing--in terms of decoration, this is a variation of molding.

4. Etching (represented by only two fragments). 


\section{METHODOLOGY}

The principal 1 iterary sources used for this study were Kendrick (1960), Lorrain (1968), Newman (1970), Jones (1971), and Miller and Sullivan (1981). Site reports were used to corroborate the artifact identifications. The reports consulted were by Brose and Rupp (1967), J. W. C1 ark (1984), J. E. Ehrenhard (1973), and B. L. Fontana (1968). A couple of collector's journal publications were also used (Maust 1967; Stephens 1979). The artifacts were compared to the 1 iterature to assess a chronology of recognizable techniques. In most cases, a general type of technology was recognizable, but fine differences between techniques were not. When working with fragments, this is to be expected. For example, basal fragments which appeared to be blown in a mold were identifiable, but whether a one-, two-, or three-piece mold was used is not always identifiable. Even with the difficulties of recognizing fine differences between different technologies, the general observable characteristics give a reasonable idea of chronology via telltale signs of manufacturing techniques.

When dating artifacts by comparing 1 iterature with visible technological evidence certain problems will be encountered. It must be remembered that various nonmechanical techniques of bottle and $g 1$ assware manufacture persist. As wel1, the reuse of a vessel would prevent its entry into the archaeological record for a number of years after the 1 iterature assigns an end to the use of a specific technique. The continued usage of return for deposit soda botties is a contemporary example of bottle reuse.

The dates given in this chapter focus on peaks of popularity. If an early date is given for a specific technique, it must be kept in mind that this is an introduction date for the widespread acceptance of that technique. This dating is based on historical evidence such as patent dates, factory day books, shipping orders, etc. At any given time in the early 19th century, many different processes would be in contemporaneous use. An end date for a process is the suggested date for the acceptance of a new technique within the industry.

The property on which the site was found has a complex history as discussed in Chapter 2. The uppermost portions of the deposits within the former military trench had been totally removed by bulldozing. An unknown amount of material was removed initially. On the 1 ast day of excavation, the unexcavated portion of the site, approximately 29 cubic yards, was removed by bulldozers and taken to the 1 aboratory for screening. A number of artifacts, including glass items, were recovered; the majority of artifacts from this site, however, were recovered from excavated contexts. Additional materials were obtained from screening the dirt taken to the 1 aboratory. A11 materials not found in a primary context were catalogued with a provenience of "Backdirt" (BD). Items discussed in this chapter which were not from an excavated context are the basal fragment shown in Figure 44, a; the basal fragment shown in Figure 45,c; the basal fragment shown in Figure 46,d; and the neck/1 ip fragment shown in Figure $45, \mathrm{~b}$. The primary goal of this study was to establish a chronological base for the glass items recovered using visible manufacturing techniques. 
Four production technologies were recognized among the artifacts:

1. Free blown, with pontil. Possible subvarieties are sand-tipped, or bare iron. The pontil is an iron rod used to hold the vessel, particularly bottles, while the mouth and 7 ip are shaped. When the bottle is sufficiently cooled to retain its shape, the rod is tapped with a mallet which breaks it free from the base of the bottle. This leaves a distinctive circular scar. Bare iron rods often leave a reddish discoloration and distort the shape of the kickup or basal indentation. T. S. Newman (1970:70) reports that an improved iron pontil rod was developed in the early 1840s. Just what the improved pontil process is, according to Newman, is unclear. Jones (1971:6869) suggests that the improvement in the bare iron technique was the tipping of the rod with a gob of sand or glass. Both of these techniques minimized the distortion caused by breaking the rod free of the vesse7. Sand-tipping increases the amount of foreign (nonglass) inclusions, but reduces distortion and the roughness of a break. GTass-tipping was not positively identified in this collection.

2. Blown-in-mold (BIM). Several subvarieties exist, but only a two-piece and a three-piece technique were recognized in this collection.

3. Pressed glass.

4. Semiautomated or fully automated manufacture.

A fifth technology is hinted at, but not definitely discernible, the turn or paste mold technique. This is essentially a variation of mold-blown bottles, but seams and other characteristic marks are removed.

The glass assemblage was divided into six major descriptive catagories with three or more subdivisions within each:

\section{A. Basal fragments}

1. B1ack basal fragments with kickups and/or pontil scars.

a. Bare iron pontil (to 1840).

b. Sand-tipped or glass-tipped variety of improved emponti 11 ing technique (after 1840).

c. BIM (b1own-in-mo1d), with the year 1810 marking the beginning of widespread popularity of the two-piece hinged mold, and 1821 as the beginning of the three-piece hinged mold as a popular manufacturing process.

2. Green basal fragments with kickups and/or pontil scars.

a. Bare iron pontil (to 1840).

b. Sand-tipped or giass-tipped variety of improved emponti 11 ing technique (after 1840). 


\section{c. BIM, (as described in $A .1, C$ ).}

3. Clear basal fragments with kickups and/or pontil scars. Since several shapes were represented in this collection, the clear glass basal fragments are subdivided into four categories: base with square facets, base with round facets, base with impressed decorations, and plain base. These represent several types of vessels, with the faceted shapes believed to be decorative decanters or drinking glasses (Anne Fox, CAR, personal communication).
a. Bare iron pontil combined with BIM (1810-1840).
b. BIM combined with improved empontil1ing techniques.
c. Other processes such as flint glass and paste mold.

4. Aqua basal fragments with kickups and/or pontil scars.
a. Bare iron pontil (to 1840).
b. Sand-tipped or glass-tipped variety of improved pontil (after 1840).
c. BIM, (as described in $A .3, b$ ).

B. Neck/Tip fragments.

1. B1ack neck/lip fragments.

a. Sheared 1ip (to 1840).

b. Applied 1ip--1aid on bead (popular through 1850s).

c. Applied 1ip--1aid on ring (popular through 1850s).

d. "Prescription finish" indicates a toiletry or medicine bottle. The finish treatments shown in Figure $43, a-j$ are some of the known available styles in the 19th and early 20 th centuries (I1 1 inois G1 ass Co. 1903-1904). Wine and 1 iquor bottle treatments are very similar and were the -diagnostic 1 ip fragments that dominated the collection.

2. Green neck/lip fragments.
a. Sheared 1 ip (to 1840).
b. Applied $1 \mathrm{ip}--1$ aid on bead (popular through 1850s).
c. Applied 1 ip--laid on ring (popular through 1850s).
d. Other processes, such as lipping tools. The neck treatment
or style of the finish shape is diagnostic of the maker's 
original intended use. "Prescription finish" indicates a toiletry or medicine bottle. Wine and 1 iquor bottle treatments are very similar and were the diagnostic 1 ip fragments that dominated the collection.

3. Aqua neck/lip fragments.

a. Sheared 1 ip (to 1840).

b. Applied 1ip--1aid on bead (popular through 1850s).

c. Applied 1ip--1aid on ring (popular through 1850s).

d. Other processes, such as 1 ipping tools. The neck treatment or style of the finish shape is diagnostic of the maker's original intended use. "Prescription finish" indicates a toiletry. or medicine bottle. Wine and 1 iquor bottle treatments are very similar and were the diagnostic 1 ip fragments that dominated the collection.

4. Clear neck lip fragments.

a. Sheared Tip (to 1840).

b. Applied 7 ip--1aid on bead (popular through 1850s).

c. App 1 ied 1 ip--1aid on ring (popular through 1850s).

d. Other processes, such as 1ipping tools. The neck treatment or style of the finish shape is diagnostic of the maker's original intended use. "Prescription finish" indicates a toiletry or medicine bottle. Wine and liquor bottle treatments are very similar and were the diagnostic 1 ip fragments that dominated the collection.

C. Tablewares, represented by decanter and serving dish fragments.

1. Decanter stoppers.

2. BIM candlestick base.

3. Pressed or BIM serving dish base.

4. Pressed wares.

a. clear.

b. blue.

D. Lettered fragments (on ly four artifacts of this type were in the collection).

1. Clear body with embossed lettering. 
Figure 43. Common Neck/Lip Treatments. a-h, 19th-century vesse 1s adapted from the II 1 inois Glass Co. (1903-1904) catalog; i, semiautomated or fully automated process for basal valve mark; $j$, neck treatment. The items shown in $i$ and $j$ are apparently pieces of the same vessel. Both were found in Unit $H_{\text {. }}$

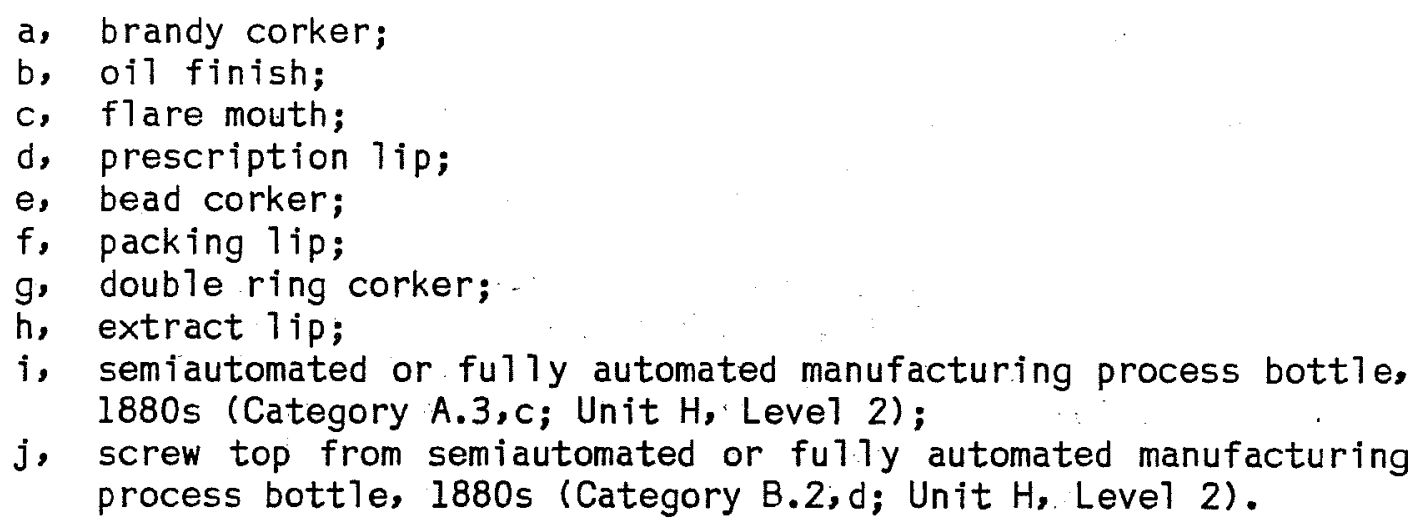




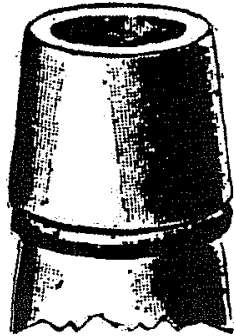

a

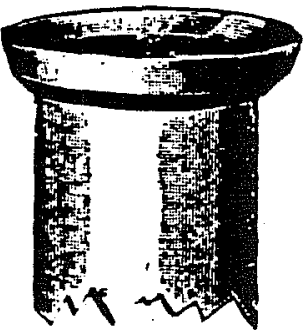

d

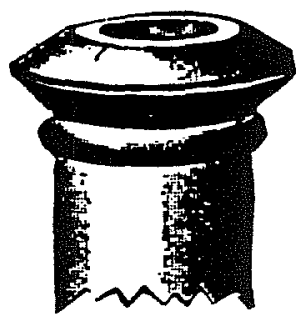

$\mathrm{g}$

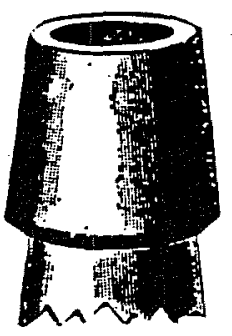

b

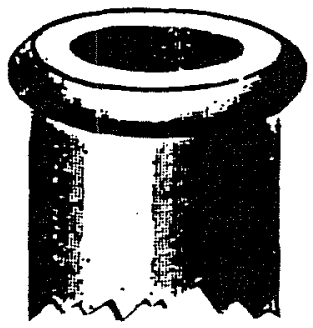

e

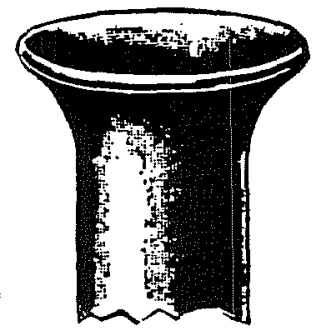

C

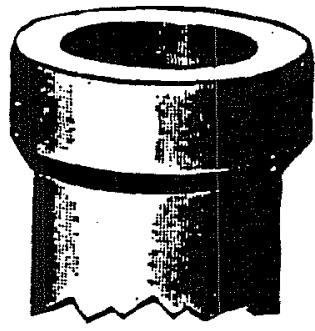

$f$

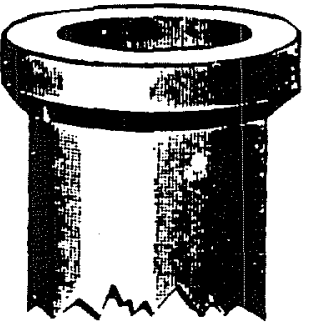

$h$
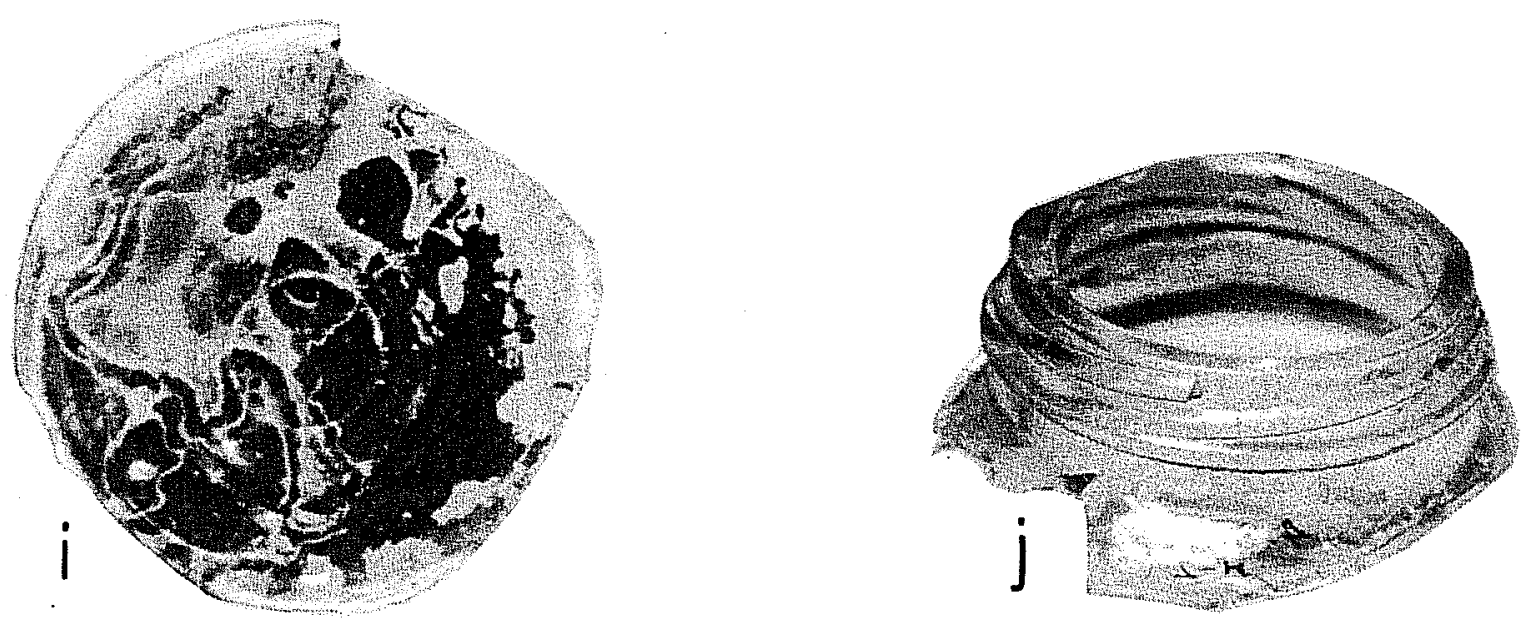
2. Green 1ettered plate or tag, thought to be a slug plate molding process dating from 1850 (Newman 1970:72). At this writing, the slug plate is thought to be a molding or stamping method that produced embossed lettering.

3. Lettered basal fragment, clear and BIM or pressed.

E. Miscel 1 aneous and unidentified glass artifacts.

1. Decorated vessel fragments which are cut and etched, etc.

2. Window glass fragments, tentatively identified.

3. Drawer pul1.

F. Fragments, 1 isted by color and production technique (when identified).

1. Black, bottle glass.

2. Black, unidentified.

3. Green, bottle glass.

4. Green, unidentified.

5. Clear, thin glass thought to be window pane.

6. Clear, heavy glass thought to be flint glass.

7. Brown glass.

8. White glass.

\section{DESCRIPTION AND DISCUSSION OF GLASS ARTIFACTS}

The recovery from the excavations and 1 aboratory-sifted backdirt produced 868 glass fragments. Seventy-two of these were separated for study based on observable characteristics of glassmaking technology. These "diagnostics" were mostly basal and neck/1ip fragments. Some body fragments showed identifiable signs of various technologies, and these also were selected as diagnostics, although no positive assessment of the original vessel form could be inferred. Most of the basa1, neck, and tableware fragments were from vessels produced in quantity in American and British glasshouses throughout the 1830s, 1840s, and 1850s.

Some of the glass items found at the site appear to be flint glass, clear and fairly heavy, as wel1 as inexpensive, and a substitute for crystal. The process for making flint glass was in use in England by 1753 (Chambers 1847:118-119; Benjamin 1880:46-48; Putnam 1968:67-69). In the mid-19th century, flint glass was widely available in the United States. Like pressed wares, flint wares were enjoying plenty of popularity during the 1830 s and 
1840s. England was the primary source for flint wares consumed in the Americas prior to 1850. Flint glass objects with the BIM process often were annealed to remove obvious mold marks. Pontil scars would have been ground and polished away. Thus, the actual technology of shaping the vesse 1 is unidentifiable in most of the flint glass pieces.

For many of the bottles in the collection, the finish of the mouth, neck, and 1 ip sections was carried out by hand until the semiautomated and ful1y automated processes were in production. A 1 ipping tool was used to finish the bottle $1 \mathrm{ip}$ and shape the collar. Dating on the $1 \mathrm{ipping}$ tool is uncertain. The marks left by these tools appear as striations spiralling up the neck to the top part of the bottle.

The sheared 1ip, popular to the 1840s, is exactly what it sounds 1 ike. The 1 ip is roughly cut, and an app 1 ied bead or ring of $g 1$ ass is added to create the collar below the mouth of the vesse1. This "collar" feature is designed for corking or sealing the bottle. Therefore, finish treatments are often referred to in the 7 iterature as corkers.

Category A.l consists of black basal fragments with kickups and pontil scars. Black glass, which is actually a dark olive green, indicates a high iron content in the chemical mix. The heavy black glass was used for wine and 1 iquor bottles, since dark glass was believed to protect wines and 1 iquors from harmful sunlight. Many modern wine bottlers have continued this tradition (Se1don 1983:234-237). Seven artifacts fit this category. The distortion of the kickups, along with the reddish discolorations and foreign inclusions in the glass, is indicative of the use of a bare iron pontil, which was popular up to the 1840s. Figure $44, d$ shows a cross section of a shallow kickup that is $35-40 \mathrm{~mm}$. This fragment was broken right through the center, making recognition of the empontilling technique uncertain. It is thought to be a bare iron pontil technique. The basal diameter of Category A.1 bases ranges from 80 to $90 \mathrm{~mm}$. Average thickness varies from 9 to $13 \mathrm{~mm}$. Such variation can be expected with free-blown objects.

One black basal fragment is part of a vessel made with a three-piece BIM process. A sand-tipped, improved variety, pontil was used. This piece is thought to date to within a few years of 1840. While the mold process gives an early date of 1821, the improved ponti 1 technique dates the object to 1840 and after, and the black glass suggests an early 19 th-century date (see Fig. $45, g$ ).

Category A.2 consists of green basal fragments with kickups and/or pontil scars (Fig. 44,a,c). One distorted kickup (not illustrated) of varying thickness has 1 arge pieces of jagged glass adhering to its insides. This piece is clearly made with a bare iron pontil and is dated to 1840 or earlier. Figure 44, a shows a high kickup. This kickup is very smooth and rounded. A very thin, circular scar is present inside the crown of the pontil. Along the scar marks, discolorations and inclusions indicate the use of a bare iron pontil. On the outer rim of the base, where the vessel would stand on a flat surface, there is an abrasive or smoothing wear discernible. Most of the basal fragments in the collection show this type of wear, indicating extensive use before discard. Figure 44,c shows a high, distorted kickup, but the pontil mark is surprisingly smooth. It is suggested that 
this piece was made with an improved, possibly a sand or glass-tipped pontil, technique, dated 1840-1870 (Newman 1970:72; Jones 1971:67-68).

Category $A .3$ is represented by clear basal fragments. The category is subdivided into four different basal shapes, the first of which is a squarefaceted base. These bases are very thick, $15 \mathrm{~mm}$ and more. The basal indentations are very shallow $(3-5 \mathrm{~mm})$ and are not rough or distorted but are off-center. The slightly uneven surface texture indicates the use of a mold. The mold appears to be a three-piece mold, which would leave recognizable seams only on the upper shoulders and neck of the bottle. The two-piece mold, popular and available from 1810, would show a seami cutting through the base (as in Fig. 45,c). Although the three-piece mold developed at roughly the same time as the two-piece, the Ricketts model proved most popular after 1821. The three-piece process often was combined with an improved variety of ponti1. The Ricketts Company used the improved sand-tipped variety of ponti 1 (Jones 1971:67-68). Square-faceted, clear basal fragments (Category A.3) suggest the use of a BIM technique. No mold seams are visible, but the surface texture is definitely that of a BIM item. The suggested date for these square-faceted, clear basal fragments is 1821-1870.

The collection also contains a small basal fragment (not illustrated) that has 10 facets; the basal diameter is $30 \mathrm{~mm}$. On one of the 10 parels the embossed letters "DE MIDY" appear. The piece has a very shallow indentation in the base and is of exceptionally clear, heavy glass. However, numerous small internal bubbles and striations are visible. It is suggested that this is a kind of $f 1$ int $g l$ ass that dates throughout the 19 th century. Flint glass enjoyed a peak of popularity in the $1830 \mathrm{~s}$ and $1840 \mathrm{~s}$. In a 1 , seven bases with squared facets were recovered and can be dated to this period.

Clear basal fragments with rounded facets (Category A.3) consist of two recognizable specimens. The only complete sample, shown in Figure 45,e, is $65 \mathrm{~mm}$ in diameter. The pontil scar is suggestive of the bare iron technique, and the facets and surface texture suggest a BIM item. These specimens are dated 1821-1840.

The category of clear, round bases, with impressed designs (Category A.3,c) is also represented by two specimens; one is shown in Figure 45,d. Both fragments are bases from BIM vessels. No pontil scars are present, but the rough surface texture of the molded item does exist. The complete fragment shows 12 regular facets in an elongated diamond shape that radiate from a central bead forming a stylized star or sunburst. Note the similarity to the pressed glass decanter top shown in Figure 46,b. These bases consist of a very heavy, clear glass with few noticeable flaws, such as bubbles and varied thickness. The basal fragment shown in Figure 45,f has a pontil scar and the familiar molded surface texture. The crushing along the breaks of this piece obscures positive identification of the empontilling technique used. The clear, heavy glass suggests flint glass. It is interesting to note that flint glass, as a relatively inexpensive replacement for fine crystal, was sti 11 costly. The worn areas surrounding the base suggest extensive use. Flint glass was widely produced in the United States during the 1840s. Before that time, England had been the leading producer of the $\mathrm{flint} g 1$ ass consumed in the Americas. 

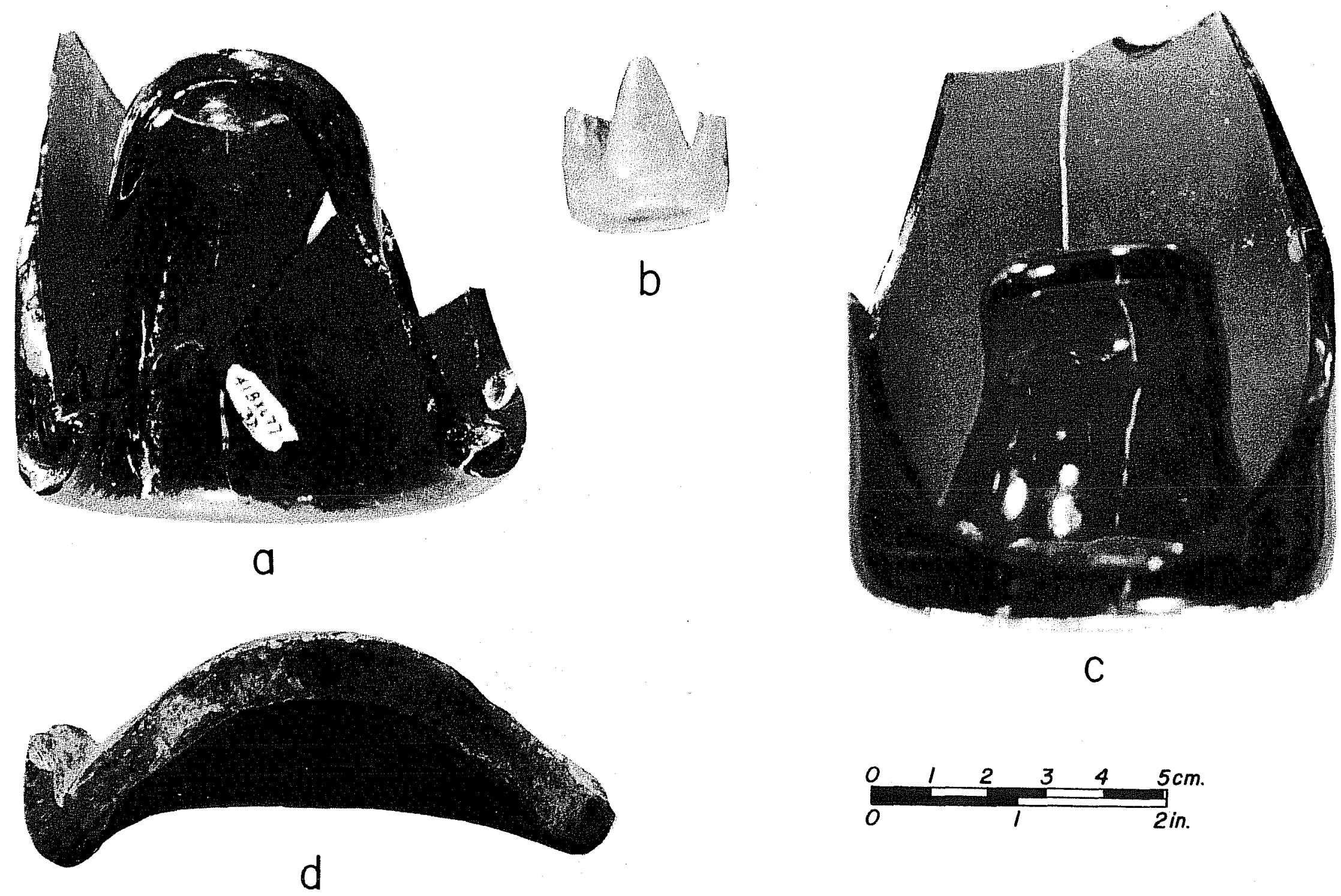

C

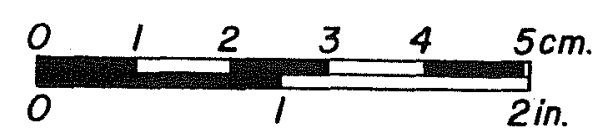

Figure 44. Basal Fragments. a, green basal fragment, $70 \mathrm{~mm}$ in diameter, with a kickup of $38 \mathrm{~mm}$. Bare iron pont1l process, free-blown. Dated to 1840, possibly before 1821 (Category A.2,a; BD); b, clear basal fragment, $25 \mathrm{~mm}$ in diameter, with a high molette kickup of $25 \mathrm{~mm}$; dated to 1840s (Category A.3, Unit M. Level 5); c, green basal fragment, $75 \mathrm{~mm}$ in diameter, with a $35 \mathrm{~mm}$ kickup; free-blown. Uncertain empontilling process; dated to 1840 (Category A.2,a; BD); d, black basal fragment, $85 \mathrm{~mm} 1 \mathrm{n}$ diameter; bare iron pontil process; dated to 1840 (Category A.l,a; Unit NW, Leve1 1). 
Figure 45. Clear and Black Basal Fragments.

a, clear basal fragment, round, free-blown rough ponti 1 , dated 1840, but possib7y before 1821 (Category A.3,c; Unit L-1-6);

$b$, aqua basal fragment, free-blown with rough pontil (Category A.4,a; Unit NW, Leve1 1);

c, aqua basal fragment, BIM, two-piece with bare iron pontil, diameter is $40 \mathrm{~mm}$, dated 1818-1840 (Category $A .4, C$; BD);

d. clear basal fragment, flint glass with impressed design, dated to 1840 (Category A.3,C; Unit C, Leve1 1);

e, clear basal fragment, BIM with rough pontil. Possibly flint glass, dated to 1840 or earlier (Category A.3, a; Unit B, Leve1 6);

f, clear basal fragment, rough pontil, dated to 1840 or earlier (Category A.3,a; Unit M, Parapet Fil1);

$\mathrm{g}$, b1ack basal fragment, $100 \mathrm{~mm}$ in diameter, BIM in three-piece mold with improved, possibly sand-tipped ponti $1,1821-1840 \mathrm{~s}$ (Category A.I,C; Unit D, Leve1 4). 

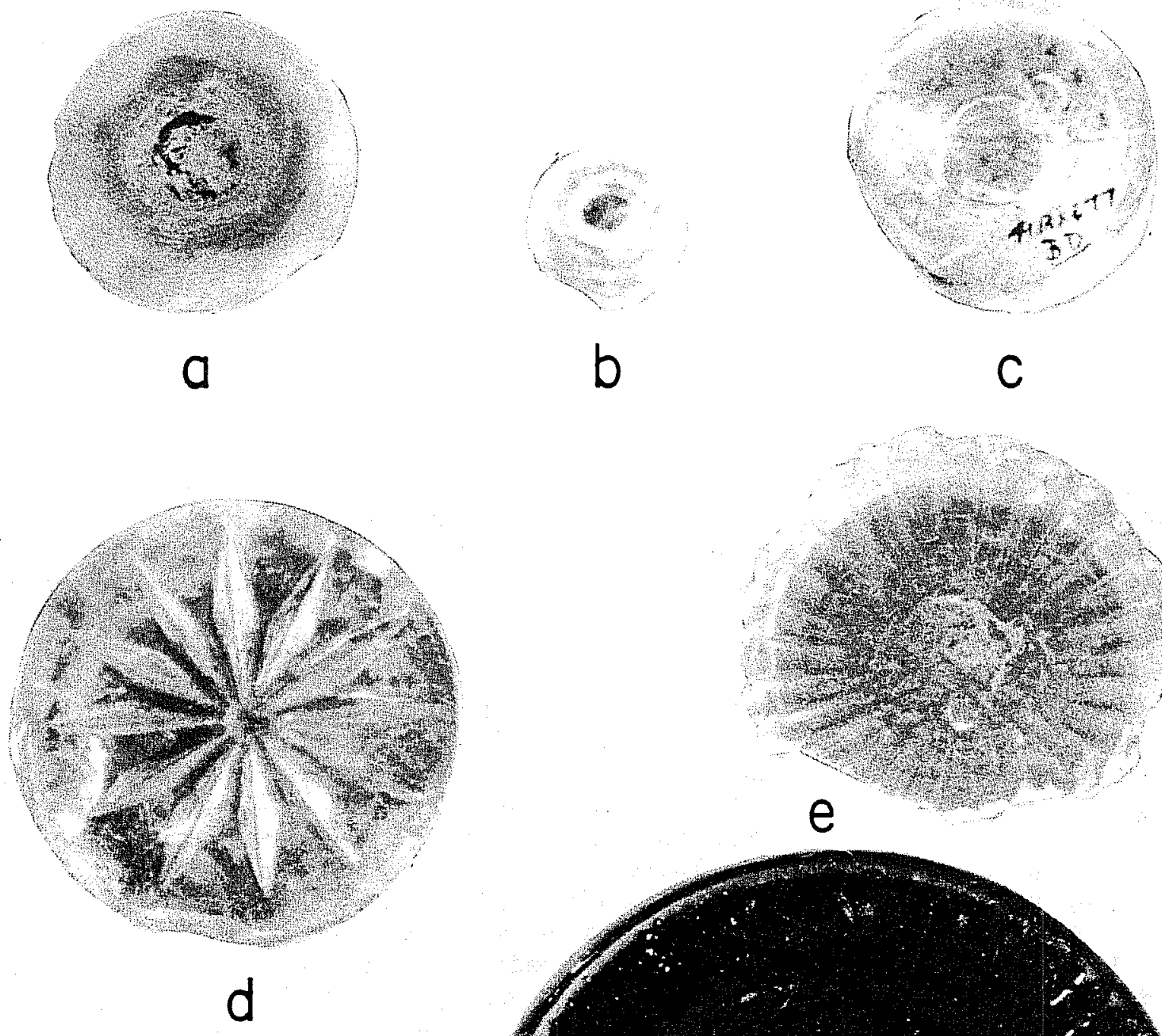

b
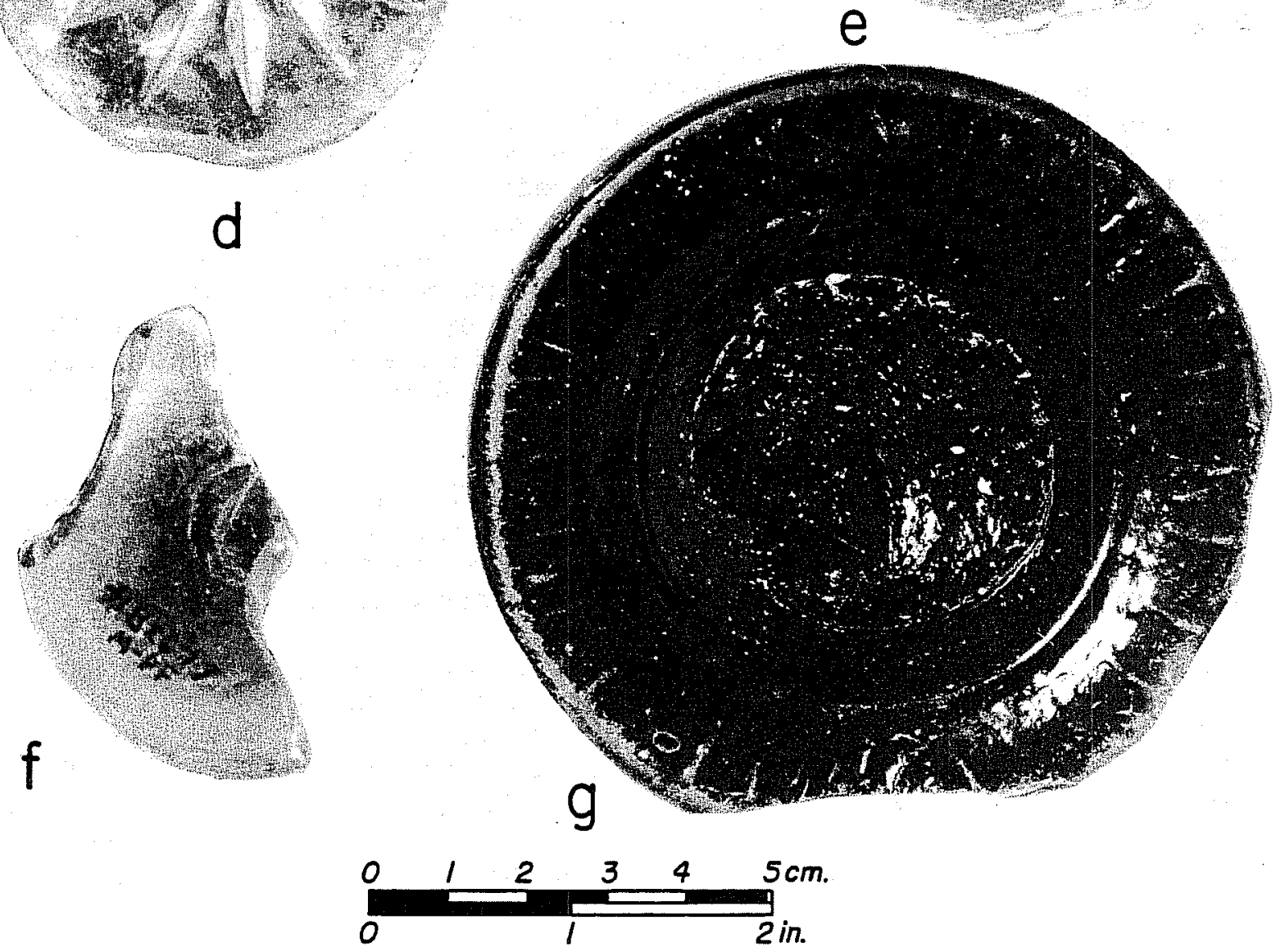
Five specimens are clear, undecorated, round basal fragments which show various manufacturing technologies. One specimen is a clear, heavy fragment (65 mm in diameter) that has a varying thickness. A pontil scar is present, tentatively identified as an improved variety, dated after 1840. The rim of the base shows extensive use wear. Figure 45, a is a 45-mm diameter base which shows wear on the rim and a ragged pontil scar that exhibits internal discoloration and inclusions. This is the product of the bare iron pontil technique, which dates to 1840 or earlier. Both of these specimens appear to be free-blown, as no mold seams or surface textures are visible. This suggests a date before the popularity of mold-blown items, 1820-1821 (Lorrain 1968:43; Newman 1970:72; Jones 1971:66).

An extremely small basal fragment (25 $\mathrm{mm}$ in diameter), with a very high kickup of $25 \mathrm{~mm}$, does not show the characteristic discoloration or distortion of the bare iron pontil technique (Fig. 44,b). The high, smooth conical indentation and 1 ack of any seams or surface texture suggest that a technique not discussed in this study was used. It is suggested that a device such as a molette--a punchlike instrument popular in France to the $1840 \mathrm{~s}--$ was used to shape this base (Gillespie 1959:231; Jones 1971:63). The sma11 size suggests a perfume or toiletry bottle.

The basal fragment shown in Figure 43, $i$ is $65 \mathrm{~mm}$ in diameter and is on 1 y $5 \mathrm{~mm}$ thick. The thickness shows a sijight degree of variation. A large valve mark indicates that this specimen was made by a semiautomated or ful1y automated process. The internal bubbles and flaws, as well as the off-center mark with its surrounding rings, date this as a late 19th-century process. The earliest possible date is the 1880s. The Arbogast and Ashley processes were developed in the 1880s. Kendrick (1966:81) states that such valve marks could be found on bottles which were made in devices similar to pressing machines in the 1880s. More research needs to be carried out regarding this transitional process which apparently incorporated elements of pressing devices and semiautomated manufacturing processes. This artifact was found near the surface of a highly disturbed area which included excavation Unit $H$. This portion of the site was badly disturbed by the construction of the post1927 gas station (see Features 4, 5, and 6 in Chapter 3). The presence of this specimen in association with Feature 5 would tend to support the tentative dating of the feature.

A basal fragment (not illustrated), which is $70 \mathrm{~mm}$ in diameter, has numerous internal bubbles and striations. The striae are very faint, but visible on the surface of the artifact. It is suggested that this is an examp $7 e$ of a turn/paste mold process, a variation of the BIM process.

Any treatment of the vessel surface after completion represents an extra step in the manufacturing process. An extra step would mean, of course, a rise in cost. Annealing, such a step, required skilled laborers to control the temperature precisely. Turn-molded vessels had to be handled carefully as we 1 1; too much stress would tear the bott 1e open. Grinding, polishing, or cutting required the proper equipment and skilis. Only two items were tentatively identified as made by the turn-paste process. Turn-paste items are less common in a pre-1860 site (Newman 1970:73). 
Aqua basal fragments are represented by three examples; two of which are shown in Figures $45, \mathrm{c}$ and $46, \mathrm{~d}$. The large base $i 11$ ustrated in Figure $46, d$ is a BIM bottle in a flask shape. This shape was popular in the 1860 s and 1870s. The raised seams, pebbled surface, and smooth, off-center basal indentation suggest a BIM or pressed item. These items are dated to the 1860 s or 1870s, with an early date of the 1840s possible (Newman 1970:72). Both specimens were recovered from disturbed contexts.

A 40-mm diameter fragment, with a mold seam bisecting the base and pontil sciar (Fig. 45,C), was made in a two-piece mold. The rough pontil mark has discolorations and jagged $g l$ ass flecks in it. It is suggested that this item dates between 1810 and 1840. The sma 11 size and color suggest a medicine or toiletry bott1e (Lorrain 1968:38; Putnam 1968:69-80). One other aqua base has a diameter of $20 \mathrm{~mm}$ and a rough pontil scar with discolorations (Fig. $45, b)$. This item has no mold marks and is thought to be free-blown. The vessel size suggests a perfume container. These aqua basal fragments are dated before 1840. Extensive reuse, as shown by wear on the periphery of the base, is not evident. Kendrick (1966:22) suggests that aqua glass was an inexpensive, 10w-grade material used for utilitarian wares, such as patent medicines, condiments, soaps, etc.

Category B is neck/lip fragments, discussed in terms of "finish treatments." This is an assessment based on the maker's original intended use. The shape of the neck, $1 \mathrm{ip}$, and finish is thus indicative of function. Since bottles were common 1 y kept and reused, the presence of a vessel intended for one purpose might not necessarily indicate the actual usage of the bottle when it was finally broken and discarded. For example, the items shown in Figure 47,e-i are hand-finished with sheared. 7 ips and applied finishes. This typically represents a wine bottle treatment. The ring collar or finish was designed to help seal or cork the bottle. Thus, the term "treatment" will a 1 so show up in the 1 iterature as "corker." One of the necks has a 1 aid-on bead treatment, which is a 1 ate 18th-century/early 19th-century wine bottle finish (Fig. 47,h). The specimen shown in Figure $47, \mathrm{c}$ is a whisky or 7 iquor bottle treatment. The lip is a hand-applied feature, possibly shaped with a 1 ipping tool. The green wine bottle necks are of flawed green glass, apparently free-blown. Rough striations are observable in the glass. No hint of mold seams is present. It is suggested that these are indeed freeblown and date before 1821 (Lorrain 1968:36; Newman 1970:73). The sheared 1 ip treatment was in common use from 1820 to 1840 . For cheaper manufactures, sheared 1 ip bottles continued to the 1870s (Newman 1970:73).

A neck fragment, with an applied 1 ip (not illustrated), is hand-finished. The surface texture of the body and shoulder indicates a mold-blown item. The square shape and squat neck, with a 1 aid-on bead finish, are of a style popular in the 1ater part of the 18th century (Smith 1981:136). During the first 20-30 years of the 19th century, these bottles were used primarily for snuff.

Aqua neck fragments are represented by five specimens. The specimen shown in Figure $46, \mathrm{~b}$ is a $\mathrm{flask-shaped} \mathrm{shoulder} \mathrm{and} \mathrm{neck} \mathrm{piece} \mathrm{with} \mathrm{a} \mathrm{whisky} \mathrm{finish}$ and a hand-finished $1 \mathrm{ip}$, probably done with a Tipping tool. The surface texture indicates a BIM or pressed method of manufacture. The $f 1$ ask shape was popular in the 1860s. However, the mold seams which run up the sides of 
Figure 46. BIM Fragments and Slug Plate Tag.

a, clear basal fragment, BIM, faceted; possible flint glass, dated to 1840 (Category $A .3, b ; B D$ );

b, aqua neck/1ip fragment, BIM, hand finished with 1ipping tool; whisky finish,. 1870s (Category B.3,d; BD);

c, lettered plate or tag; slug plate process dated to 1850 (Category D.2; Unit $M$, Leve1 7);

d, aqua basal fragment, flask shape popular in the 1860s; BIM (Category $A .4, C ; B D$ ). 

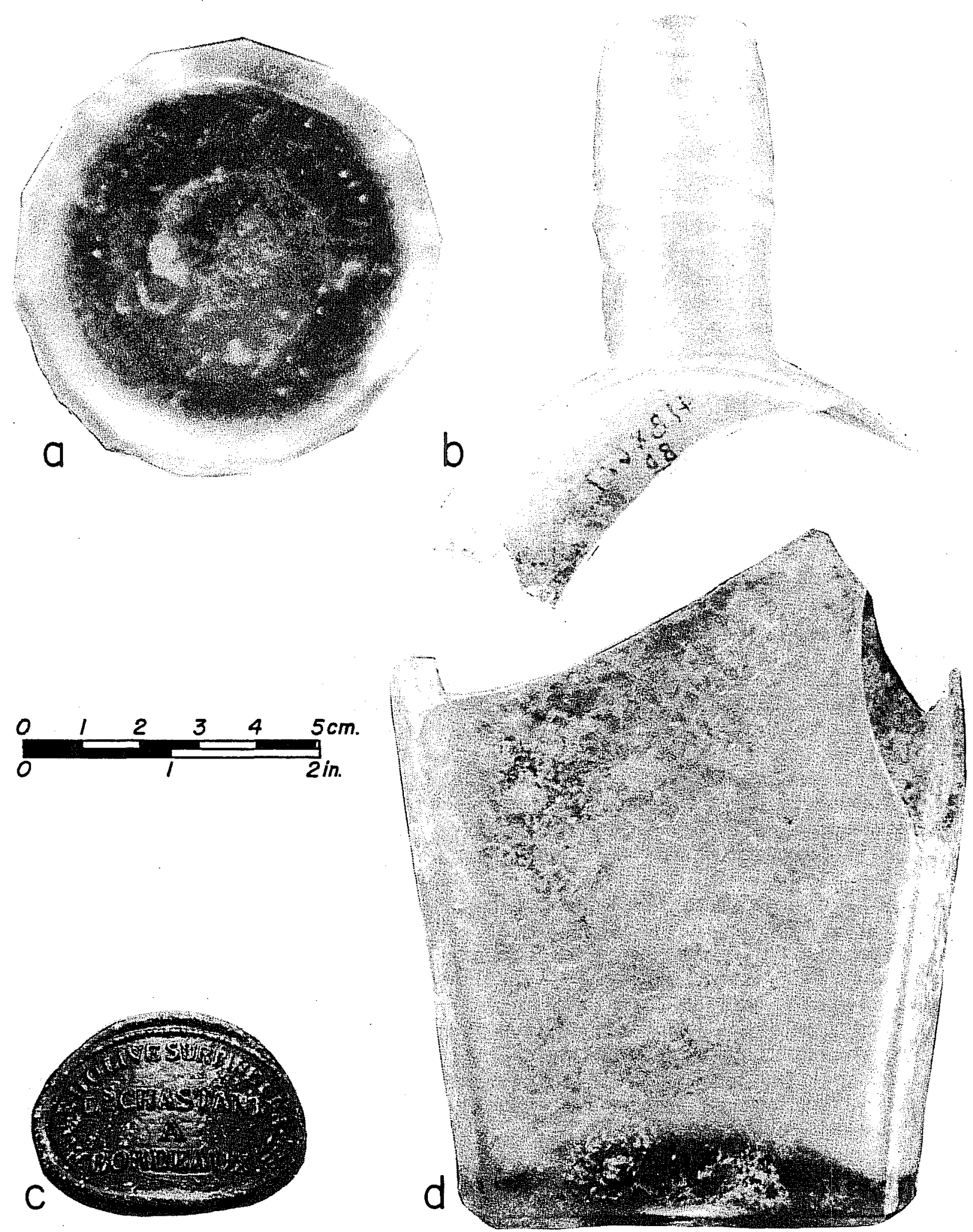
the neck indicate the usage of a two-piece mold. This specimen was recovered from dirt removed and returned to the 1 aboratory when the excavation was closed. Many diagnostics, such as these aqua fragments (Fig. 46,b,d), were recovered from bu 11 dozed fil1.

The aqua neck fragment shown in Figure 47,b, is definitely a hand-finished piece with an applied 1 aid-on bead corker. There are 18 rounded facets in a spiral, and the 1 ip is sheared. This specimen is very similar to an "Ohio Swirl" pattern identified by Putnam (1968:94-95). This pattern was popular to 1850. If the idea or the vessel was "imported" from Ohio, then trade contacts which were not exclusively controlled by the Mexican government are indicated. This fragment represents a decorative decanter. If aqua glass is considered to be cheap glass, even in the 19th century, then this piece also represents the attempt to have a formal or decorative table setting which was affordable. Since this item is a sheared 1ip, it is dated 1820-1840 (Newman 1970:73).

Clear neck/1ip fragments (Category B.4) are represented in the collection by two prescription 1 ip treatments (Fig. $47, a$ ). One is a pressed ware piece which is hand-finished (Fig. 47,d). The use of a lipping tool is not certain; the finish is an applied prescription 7 ip treatment. The glass is very thin and has, numerous internal bubbles and striae. Dating on this piece is suggested to range from 1827 to 1850. The other prescription 1 ip fragment (Fig. 47,a) also is of clear glass with numerous internal flaws. The fugitive seam which encircles the 1 ip suggests use of a 1 ipping tool. The piece is suggested to be free-blown with a hand-applied 1 ip shaped by a 1ipping tool. It is dated ca. 1850. The presence of only two recognizable prescription/toiletry bottles indicates that the materials dumped in the site preceded 1860. The period of marked interest in patent medicines and "bitters" was 1 ate 19 th century and early 20th century. Lorrain (1968) refers to this period as the "patent medicine craze." In sites dating from the 1860s, we expect to find dozens of prescription 1 ipped bott 1 es. This site does not fit this expectation. The piece of pressed ware (Fig. 47,d), which is a prescription 1 ip piece, suggests a date not before 1827 .

The collection contains only one screw top mouth/1 ip fragment (Fig. $43, j$ ). This specimen was definitely produced by semiautomated or fully automated manufacture; it is suggested that an early date for this item is 1880 . This fragment came from the highly disturbed Unit $H$ (see Fig. 11). Some of the glass materials from this area are of a 1 ater date than the items from the rest of the site. The area which includes Unit $H$ was disturbed by the excavations for the gas station pilings (Features 5 and 6; Fig. 11). This disturbance (Feature 6 ) is thus dated by the glass artifacts to the 1880 s or 1 ater. Archival research has, however, demonstrated Feature 6 can be dated to no earlier than 1927.

Category $\mathrm{C}$ is a somewhat arbitrary category of tablewares. This category includes artifacts that are considered to represent nonutilitarian items or 1 uxuries. These are represented in the collection by the decanter tops, a basal fragment which appears to be a candlestick or bud vase, blue pressed wares, and a pressed ware serving dish base. 
The decanter stopper tops are represented by four specimens. Three of the pieces are fragments, and one is complete. The complete stopper is of heavy glass that is roughly hand-cut or ground and roughly used. The clarity of the glass and the few internal flaws suggest flint glass, popular during the $1830 \mathrm{~s}$ and $1840 \mathrm{~s}$. However, the roughness of the piece suggests a less expensive method of manufacture. At present, dating is tentative. A round disclike decanter top is of clear pressed glass with a stylized star or sunburst design with eight points ( $F$ ig. 48,b). The facets are raised and radiate from a central button. The surface of the disc is studded with smal1 raised knobs which are associated with pressed wares of the $1830 \mathrm{~s}$ and $1840 \mathrm{~s}$ (Lorrain 1968:38-39; Putnam 1968:62-63). Another decanter top fragment is a pressed glass "ball" which is hollow. The surface design is small rounded diamonds. The other two decanter top specimens are pressed glass, and date from 1827.

The specimen tentatively identified as a candlestick base has a rough pontil scar on the base. This scar has foreign (nonglass) inclusions and smal1 flecks of raw glass adhering to this area. The combination of pressing and rough empontiliting techniques dates this item 1827-1840 (Fig. 48,f).

Twenty-two fragments in the collection are of pressed wares from clear and blue colored vessels. A blue rim fragment exhibits a stylized: cornucopia of flowers and stylized 1yres (Fig. 48,g). The background surface consists of numerous sma11 knobs typical1y found on pressed "1 acy ware" patterns (Lorrain 1968:38-39). This sherd is dated 1827-1850. Another fragment of the b 7 ue pressed ware is representative of 11 pieces in the collection. While no idea of vessel shape can be gained from the fragments, at least two vessels are thought to be represented.: Of the clear pressed ware fragments recovered, one is a basal fragment, shown in Figure $48, \mathrm{~h}$, from a $5 \mathrm{ma} 1 \mathrm{l}$ bow 1 . The item is of pressed glass, with a rough ponti 1 scar on the base. It is suggested that the date for this piece is 1827-1840. The original shape of the vesse1 cannot be determined with certainty, but it appears that this is a smal 1 serving or condiment bow 7 .

Four lettered pieces (Category D) were recovered from the site. Two are body fragments of clear vessels. One shows the embossed letters "NTAL," probab7y from the word "dental." Another clear body fragment has the embossed letters "OSSALE BOTTL." The first group of letters possibly is a proper name of a company or an individual. The second group of letters is from the word "bottle" or "bottler." These pieces are too fragmentary to identify the method of manufacture with any certainty.

A clear basal fragment in the collection has the embossed letters "DE MIDY" on one of $10 \mathrm{fl}$ at panels. This item is thought to be pressed or BIM flint glass. The small size suggests an expensive perfume or toiletry item was the intended content for the vessel.

A green tag or plate is embossed with the legend "HUILE D'OLIVE SURPINE CLA/FILE" (Superior class olive oil) and "Ls. CHASTANT A BORDEAUX" (Fig. 46,C). A fugitive border of raised dots runs along the upper and lower margins of the plate. Rough glass adheres to the back of the plate and a definite seam exists along this contact. Newman (1970:74) suggests that such 
Figure 47. Neck/Mouth Fragments (Category B).

a, prescription 1 ip finish, clear (Category B.4,d; Unit H, Level 5);

b. aqua Ohio Swirl-like finish, dated to the 1850s (Category B.3, a; X-1-4-B);

c, black neck/1ip fragment, hand-applied finish with 1 ipping tool (Category B.l,a; Unit $Y$, vertical provenience unknown).

d, prescription finish, clear; pressed with hand-finished mouth (Category B.4,d; Unit B, Leve1 6);

e, green neck/1 ip fragment with sheared 1 ip and applied laid on ring wine bottle finish; dated to 1840 or earlier (Category B.2,c; EM2);

f, green neck/lip fragment with sheared 1 ip and applied laid on ring wine bottle finish; dated to 1840 or earlier (Category B.2,C; west end of site, stratigraphic provenience unknown);

g, green neck/lip fragment with sheared 1 ip and applied 1 aid on ring wine bottle finish; dated to 1840 (Category B.2,C; BD);

$h$, dark green neck/1 ip fragment with sheared 1 ip and app 1 ied 1 aid on bead wine bottle finish (Category B.2,C; Unit U, Level 6);

$i$, green neck/ 1 ip fragment with sheared 1 ip and app 1 ied on ring wine bottle finish, dated to 1840 (Category B.2, C; Unit C, Level 7). 


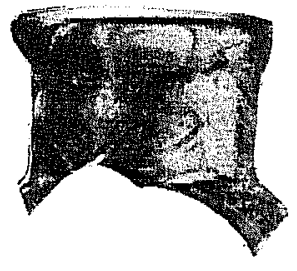

a

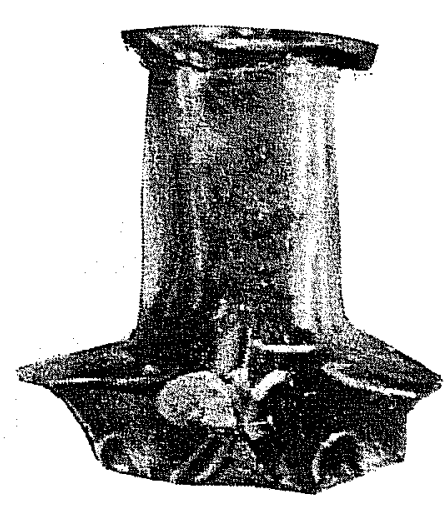

d

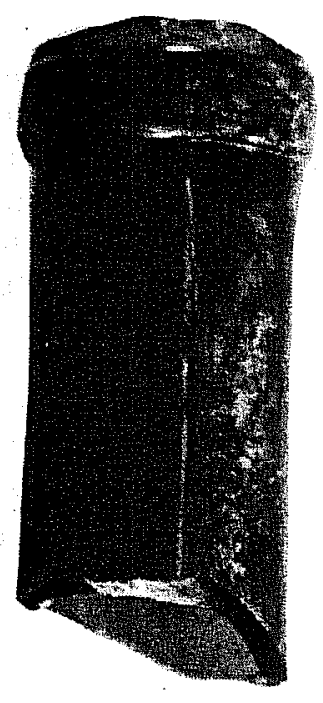

g

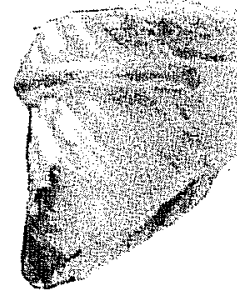

b

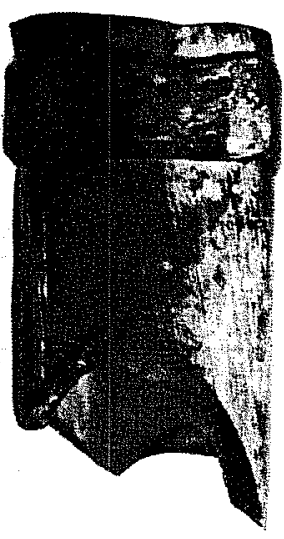

e

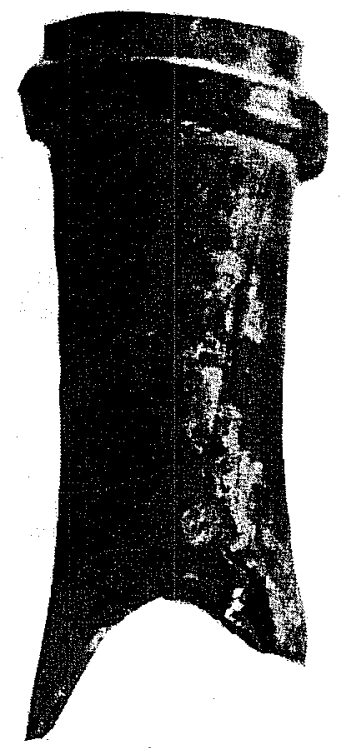

h

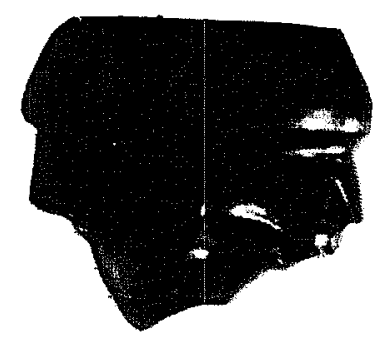

C

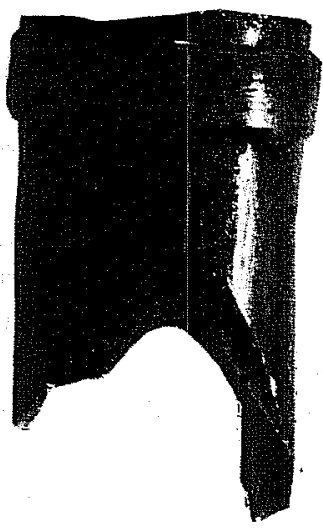

f

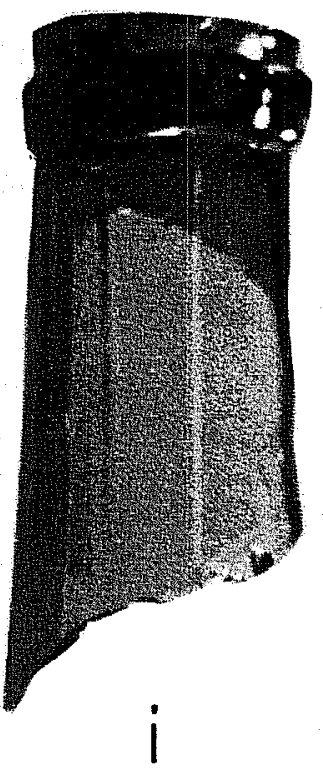

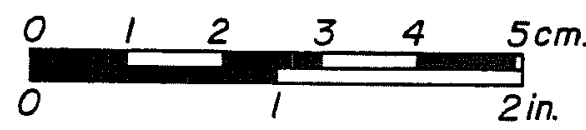


raised insets are a slug plate process dated from 1850 in the United States and 1840 in France.

Category $E$ represents miscel 1 aneous and unidentified artifacts. Only one piece of etched and one piece of cut clear glass were recovered from the site. Decorative techniques such as etching, cutting, or enamelling are poor time markers. Particular, quite distinct designs might be recognizable time markers on vesse1s. However, the fragmentary remains in this collection made positive identification of any specific pattern recorded in the literature impossible. Many of the pieces were so damaged by breakage that nothing but color and decorative techniques was recognizable. A basal fragment of what was possibly a vase is of pressed opaque white glass. A fugitive gold paint or enamel is present on parts of the surface. No positive dating is assigned (Fig. 48,d). A glass drawer pull with rounded facets is also in the collection. The piece is apparently pressed or BIM, but no positive dating is assigned here, either.

Category $F$ represents nondiagnostic fragments. These are sorted according to color. A quick assessment of texture and qual ity of glass was made. This was done to make tentative judgements regarding the technology of manufacture represented by the fragments. The "bottle glass" in this category refers to the highly flawed, dark green glass found in 19th-century wine and 1 iquor bottles. Most of the fragmentary remains are thought to be from free-blown or BIM items. Roughly half of the total collection is of clear glass pieces. At the time of this writing, the clear glass fragments are still under examination. Flint glass fragments are very difficult to separate from heavy basal fragments. At present, however, most of the clear glass is not thought to be flint glass.

\section{SUMMARY}

The entire assemblage of glass artifacts suggests a utilitarian grouping and a luxury grouping. Two major classes of bottles, 1 iquor/wine and medicine/ toiletry, are represented. The reuse of bottles is demonstrated in this collection by the worn bases. This reuse is especial1y noticeable on the black and green basal fragments. The clear, square-faceted bases are thought to be tumbler bases; these also show extensive wear (Anne Fox, personal communication).

This assemblage appears to represent a relatively expensive and, consequently, valued set of glasswares, which supports the fact that on 1 y 868 glass fragments were recovered from the site (Tables 8 and 9) compared to more than 5000 ceramic fragments recovered. It appears that the ceramic wares were more available, perhaps because they were less expensive or because they were easier to find.

Given this reuse of glasswares, any given cut-off date for a manufacturing process is a plus or minus figure. A bottle or other vessel may survive intact until one, 10, or 100 years after historical documentation assigns an end to the use of the particular process (Newman 1970:70-71; Switzer 1974:5). 
TABLE 8. GLASS ARTIFACTS RECOVERED FROM 41 BX 677

\begin{tabular}{|c|c|c|c|c|c|c|}
\hline \multirow[b]{2}{*}{ Color } & \multirow[b]{2}{*}{ Pressed } & \multirow{2}{*}{$\begin{array}{c}\text { Free-Blown } \\
\text { or BIM* }\end{array}$} & \multicolumn{2}{|c|}{ Methods of Manufacture } & \multirow{2}{*}{$\begin{array}{c}\text { Vesse1 } \\
\text { Diagnostics }\end{array}$} & \multirow[b]{2}{*}{ Total } \\
\hline & & & Unidentified & Flint Glass & & \\
\hline & 1 & 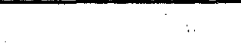 & 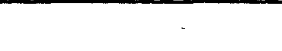 & & & \\
\hline Blue & 11 & 0 & 9 & 0 & 5 & 25 \\
\hline Green & 0 & 138 & 99 & 0 & 8 & 245 \\
\hline B1ack & 1 & 27 & 0 & 0 & 9 & 36 \\
\hline Aqua & i & 59 & 9 & 0 & 8 & 76 \\
\hline Clear & 11 & 0 & 382 & 21 & 39 & 453 \\
\hline White & i & 0 & 14 & 0 & 0 & 14 \\
\hline Brown & 1 & 0 & 6 & 0 & 0 & 6 \\
\hline Pink & i & 0 & 1 & 0 & 0 & 1 \\
\hline Other/misc. & 1 & 0 & 8 & 0 & 4 & 12 \\
\hline & & & . & & & 868 \\
\hline
\end{tabular}

*BIM - Blown-in-mold method.

Note: Seventy-two glass artifacts were selected for study. 
Figure 48. Tablewares and Miscellaneous Items.

a, decanter stopper top, flint glass (Category C.1; U-2-10);

b, decanter stopper top, pressed glass with stylized sunburst design (Category C.1; BD);

C, decanter stopper top, pressed glass (Category C.1; Unit C, Leve1 7);

d, white pressed glass, miscellaneous fragment with fugitive gold paint (Category E.1; U-2-10);

e, drawer or cabinet pull, pressed glass (Category E.3; Unit L, Leve 1. 4);

f. candlestick or bud vase basal fragment with rough pontil scar (Category C.2; Shovel test 8);

g, blue pressed ware fragment (Category C.4,b; Unit C, Level 5);

h. pressed or BIM basal fragment of a condiment or serving bow 1 (Category C.3; BD). 


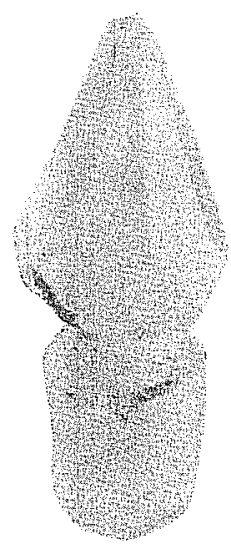

a
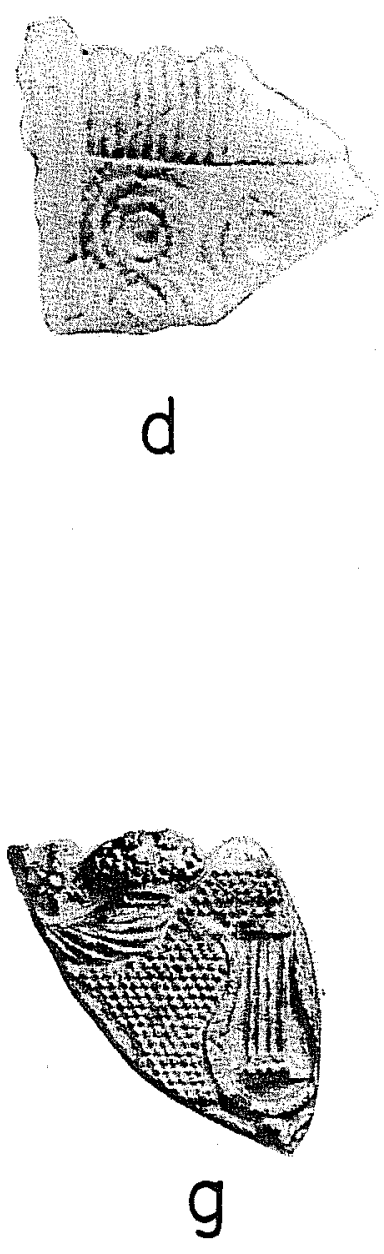

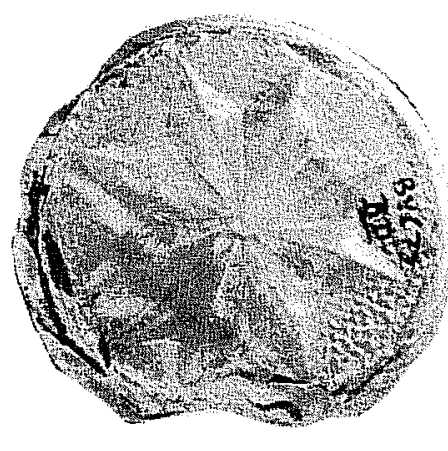

b

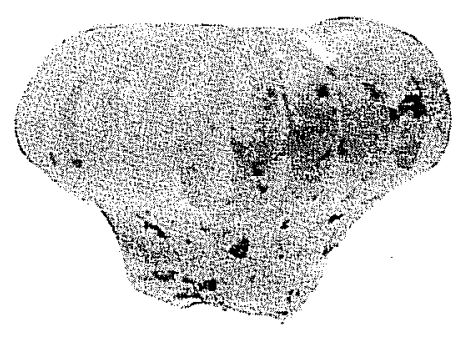

e

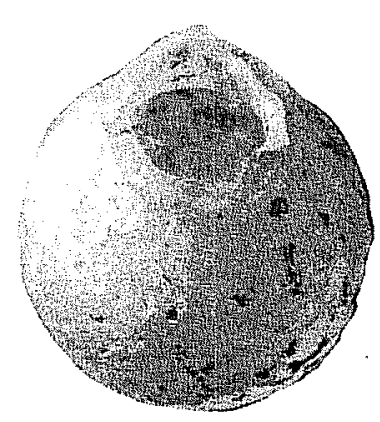

C

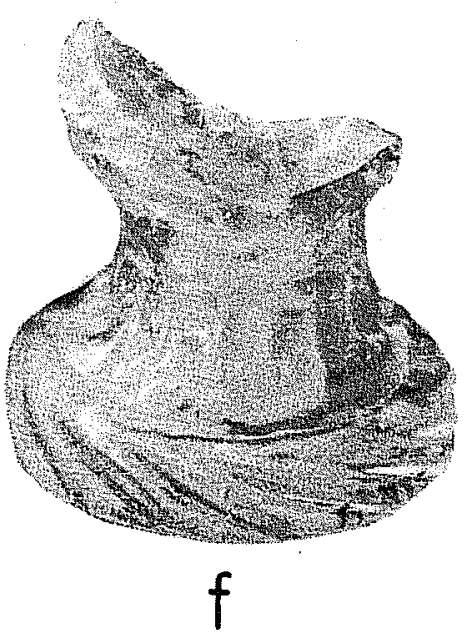

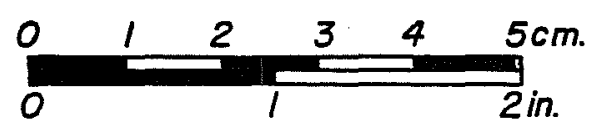

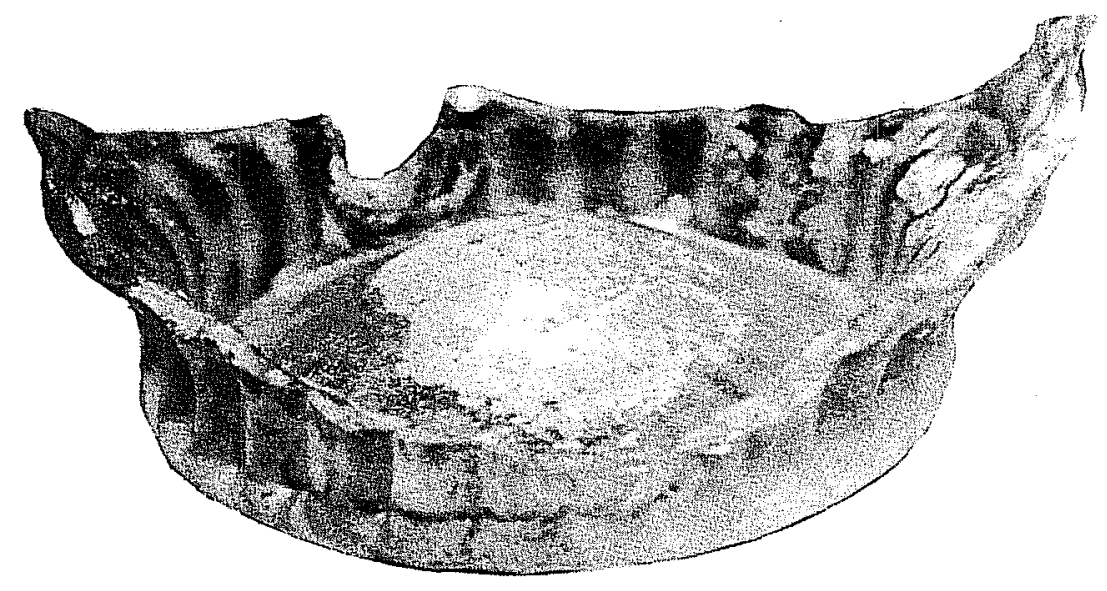

h 
TABLE 9. GLASS ARTIFACTS SELECTED FOR ANALYSIS

\begin{tabular}{|c|c|c|c|c|c|c|c|}
\hline \multirow[b]{2}{*}{$\begin{array}{c}\text { Diagnostic } \\
\text { Fragment }\end{array}$} & \multirow[b]{2}{*}{$\begin{array}{l}\text { Number of } \\
\text { Specimens }\end{array}$} & \multirow[b]{2}{*}{ Color } & \multirow{2}{*}{$\begin{array}{l}1 \\
1 \\
1 \\
1 \\
\text { Pressed }\end{array}$} & \multirow[b]{2}{*}{$\begin{array}{l}\text { Free-B lown } \\
\text { or BIM* }\end{array}$} & \multirow[b]{2}{*}{$\begin{array}{l}\text { Unknown } \\
\text { Technology }\end{array}$} & \multirow{2}{*}{$\begin{array}{l}\text { Hand- } \\
\text { Appl ied } \\
\text { Corker }\end{array}$} & \multirow[b]{2}{*}{$\begin{array}{l}\text { Lipping } \\
\text { Tool }\end{array}$} \\
\hline & & & & & & & \\
\hline $\begin{array}{l}\text { Basal } \\
\text { Basal } \\
\text { Basal } \\
\text { Square facets } \\
\text { Impressed design } \\
\text { Rounded facets } \\
\text { Plain base } \\
\text { Clear miscellaneous } \\
\text { Mouth/7 ip } \\
\text { Mouth/lip } \\
\text { Mouth/lip } \\
\text { Tableware } \\
\text { Lettered } \\
\text { Lettered } \\
\text { Lettered }\end{array}$ & $\begin{array}{r}7 \\
2 \\
3 \\
7 \\
2 \\
2 \\
8 \\
1 \\
2 \\
5 \\
5 \\
16 \\
2 \\
1 \\
1\end{array}$ & $\begin{array}{l}\text { black } \\
\text { green } \\
\text { aqua } \\
\text { clear } \\
\text { clear } \\
\text { clear } \\
\text { clear } \\
\text { clear } \\
\text { black } \\
\text { green } \\
\text { aqua } \\
\text { clear } \\
\text { clear } \\
\text { green } \\
\text { clear }\end{array}$ & $\begin{array}{l}1 \\
1 \\
1 \\
1 \\
1 \\
1 \\
1 \\
1 \\
1 \\
1 \\
1 \\
1 \\
1 \\
1 \\
1 \\
1\end{array}$ & $\begin{array}{c}x \\
x \\
x \\
x \\
x \\
x \\
x \\
x \\
x \\
x \\
\text { slug plate } \\
\text { x }\end{array}$ & $\begin{array}{l}x \\
x(3) \\
x\end{array}$ & $x(3)$ & $x(2)$ \\
\hline $\begin{array}{l}\text { Total selected for } \\
\text { *BIM - Blown-in-mol }\end{array}$ & $\begin{array}{l}\text { study }=72 \\
\text { ld method. }\end{array}$ & & & & & & \\
\hline
\end{tabular}


The glass goods that were available to the San Antonian of the 1830-1850 period include pressed table items such as serving dishes, creamers, etc.; flint wares provided fancy accents along with the decanter stoppers and candlestick bases. Utilitarian wares are represented by the 1 iquor and prescription bottle fragments. However, in the first half of the 19th century, utilitarian ware did not necessarily mean inexpensive. The glass artifacts represent an assemblage which a middle-class citizen could afford. G1 assware was, by definition, expensive until the 1860 s and 1870 s (Kendrick 1966:20; Lorrain 1968:38; Putnam 1968:69-80). The middle class cooked with condiments imported from Europe and drank a variety of wines and 1 iquor. Ladies who could afford tasteful and relatively expensive items bought perfumes and toiletries in bottles and decorative containers. The medicine cabinet is represented by on 1 y a few fragments.

The source for the glass artifacts requires further study. San Antonio was the major trade and transportation center in south and central Texas and northern Mexico since the 18th century. A7though this area was an extreme western frontier for America, Spain and Mexico had been trading for generations. It is quite reasonable to expect a market with a relatively wide selection of glass goods in San Antonio. These goods represent an active participation in a world market. The olive oil seal (Fig. 46, C) gives some indication of the extent of these trade contacts. 01 ive $0 i 1$ from Bordeaux must have been an expensive item. However, what is important is that the product was available. The flint glass pieces, tentatively dated before 1840, could have been produced in Britain. Flint glass was generally available in the United States from the 1840s, and most of this ware was produced on the eastern seaboard (Putnam 1968:69-80). The piece of Ohio Swirl-1ike ware indicates trade contacts with other regions of the United States which were more extensive than usually indicated in history texts. Much work remains to be done in this area.

As stated before, the availability of a wide selection of imported goods is not surprising. San Antonio had been a hub of travel and trade since the Mission Period. The Camino Real was the major mission route through the village to east Texas. The Matamoros Road 1 inked south Texas to northern Mexico. This important freighting route was used by General Urrea in 1836. During the westward expansion through Texas after the 1836 Revolution, San Antonio was the major center of operations. Pool, Triggs, and Wren (1975:9398) identify a Hill Country Frontier period from the years 1836 to 1860 and a Rio Grande Frontier period, 1848-1860. In this phase of expansion in Texas, several mapping and exploring expeditions used San Antonio as a base. These expeditions were 1 ed by Hays in 1848, Neighbors and Ford in 1849, Smith and Whiting in 1849, and Bryan in 1849. By the Civil War, more than seven major freighting and travel routes radiated from this growing center. Given this long period of trade and the number of routes, it is logical to expect that a wide variety of goods would be available to those who could afford them.

The earliest known glassmaker to open a shop in San Antonio was G. A. Duerler. The Sunset Mineral Water Bott 1 ing Works opened in 1857 and fronted 220 West Commerce Street and 423 West Market Street (Appler 1905-1906). Given this 1 ate date for a 1 oca $1 \mathrm{~g} 1$ assmaker, as we 11 as the fact that the Canterbury-Riddle home was built after 1858 (Chapter 2), effectively sealing 
the lot, it must be assumed that the majority of the glass artifacts found at the site were all from glass vessels shipped to the town.

Additional research should include the search for glassmakers in other areas of Texas and shippers of glass-packed goods during this time period. For example, was Ls. (Louis?) Chastant of Bordeaux a bottiing or an exporting company? Did the company have an agent in Texas? The problem of origins for this glassware presents a number of areas which need to be examined. Much of this research will center primarily on historical document studies.

The glass artifacts represent trade 1 inks which are not exclusive to a Mexican government-dominated trade network. Given the bias of the 1 iterature examined to date, the vessels appear to have originated in Britain, France, and America (Lorrain 1968:35; Putnam 1968:69-80; Jones 1971:72). This does not exclude Mexican government-sanctioned trade which would include British goods. If Santa Anna bought British military hardware for his army, it is certain that extensive trade links existed which would bring other goods. At present, a reasonable idea of what the trade routes were does exist. What remains to be determined is what and in what quantity were goods being sent via these routes.

\section{CONCLUSIONS}

The glass artifacts from site 41 BX 677 represent a shopping 1 ist of expensive items which the middle-class people could afford. Glassware was, by definition, fairly expensive until the 1870s. Roughly half of the collection is of clear fragments. Several of the clear basal specimens are apparently formal dishes, fancy drinking glasses, etc. Only the decanter tops and the candlestick can be described as luxury items. The utilitarian wares represented by 1 iquor and wine bottle fragments are not out of place in this assemblage. The fact that expensive items were purchased is proven by the presence of the embossed panel which states the vessel held a superior class French olive oil. There is a noticeable 1 ack of prescription 1 ip treatment bottles, only two specimens in the collection. A site dating to the 1 ast quarter of the 19th century would be expected to produce dozens of identifiable prescription 1 ip fragments. This site can thus be $p 1$ aced before the 1860-1900 national fascination with patent medicines (Kendrick 1966:44; Lorrain 1968:44; Carley 1981:19-27).

This study has not focused primarily on provenience or stratigraphic context. It was designed to isolate specific technological attributes which could be used to construct a chronology for glass items from the site. When it is stated that a technology was used between specific years, it means that the artifact could have been produced at any given time within that period. The chronology of glass technology is poorly known, and some techniques may date earlier than currently thought. If the deposit is secondary refuse, as is thought, and was filled in after the battle, it would be possible to find bottles from 7 ater and earlier years in a trench dug in 1836.

San Antonio's citizenry, by 1858, had a wide range of glass items available for purchase; these included pressed, blown-in mold, and free-blown glass table settings. Decanter sets were available in stylized diamond and star 
(or sunburst) designs. European condiments, wines, and whiskies also were on the market. The $\mathrm{g} l$ ass artifacts thus represent a trade network which 7 inked San Antonio to America, Britain, and France, as well as Mexico. The presence of glassmakers in San Antonio is not documented before 1857. At this time, it must be assumed that most of the glassware recovered in this site was shipped into the city.

\section{REFERENCES CITED}

Appler, J.

1905-1906 General Directory of the City of San Antonio. Privately printed.

Benjamnin, P., editor

1880 Appleton's Cyclopedia of Applied Mechanics: A Dictionary of Mechanical Engineering and the Mechanical Arts. Vol. II. D. Appleton and Co.s New York.

Brose, D. S. and D. W. Rupp

1967 The Custer Road Dump Site: An Exercise in Victorian Archaeology: 1876-1896. The Michigan Archaeologist 13(2):36-128.

Carley, C. D.

1981 Historical and Archaeological Evidence of the 19th Century Fever Epidemics at Hudson's Bay Company's Ft. Vancouver. Historical Archaeology 15:19-35.

Chamber's

1847 Chambers's Information for the People: A Popular Encyclopedia. Vol. II. G. B. Zeiber and Co., Phil adelphia.

Clark, J. W., Jr.

1984 Archaeological Test Excavations at an Early Twentieth Century Dump Site in North San Antonio, Bexar County, Texas. State Department of Highways and Public Transportation, Highway Design Division, Publications in Archaeology, Report 26.

Drew, $M$.

1950 An 01d Glass With a New Name. Hobbies 55:75.

Ehrenhard, J. E.

1973 The Rustic Hote1, Fort Laramie National Historic Site, Wyoming. Historical Archaeology 7:11-29. 
Fontana, B. L.

1968 Bottles and History: The Case of Magdalena de Kino, Sonora Mexico. Historical Archaeology 2:45-55.

Gillespie, C. C., editor

1959 A Diderot Pictoral Encyclopedia of Trades and Industry. Vol. II. Dover Publications, New York.

Illinois Glass Co.

1903-1904 Catalog of the Manufacturing Plant of the Il1inois G1ass Co. Alton and Chicago, Il 1 inois, and St. Louis, Missouri.

Jones, 0 .

1971 Glass Bottle Push-ups and Pontil Marks. Historical Archaeology $5: 62-73$.

Kendrick, G.

1966 The Antique Bottle Col1ector. Edwards Brothers, Inc., Michigan.

1967 Bottle Fragments Betray Age of Historical Sites. El Palacio $74(2): 19-24$.

Lorrain, D.

1968 An Archaeologist's Guide to Nineteenth Century American Glass. Historical Archaeology 2:35-44.

Maust, D., editor

1967 Bottle and Glass Handbook. E. G. Warman Publishing Co., Pennsylvania.

Miller, G. L. and C. Sultivan

1981 Machine-made G1 ass Containers and the End of Production for Mouth Blown Bottles. Parks Department, Research Bulletin 171. Canada.

Newman, T. S.

1970 A Dating Key for Post 18th Century Bottles. Historical Archaeology 4:70-75.

Pool, W. C., E. Triggs, and L. Wren

1975 A Historical At1 as of Texas. Encino Press, Austin. 
Putnam, P. A.

1968 Bottled Before 1865. Published by author. Rapid Blue Print Co., Los Angeles.

Seldon, P.

1983 The Vintage Magazine Consumer Guide to Wine. Doubleday, New York.

Smith, C.

1981 Country Artifacts and Collectibles. Oxmar House, Inc., Alabama.

Stephens, $C$.

1979 Dating and Collecting Ball Jars. The Antiques Journal:30-32.

Switzer, R. R.

1974 The Bertrand Bottles. National Park Service, Department of the Interior, Washington, D.C. 


\title{
CHAPTER 8 \\ CONSERVATION REPORT
}

\author{
Pau1 S. Storch
}

\section{INTRODUCTION}

Two iron-alloy military artifacts from site 41 BX 677 were submitted to the Materials Conservation Laboratory (MCL) of the Texas Memorial Museum, University of Texas at Austin for conservation treatment. The request was to clean the objects in order to reveal as much of the surface shape and detail as possible. Active corrosion should be arrested by the treatment, resulting in long-term stability for the artifacts. Full documentation of the objects was undertaken before actual treatment was carried out, including surface and subsurface examinations.

The MCL operates under the American Institute for Conservation's (AIC) Code of Ethics (rev. 1980), which promulgates the following guidelines and principles for treatment methods: (1) Minimum intervention; i.e.s the aesthetic, chemical, and physical properties of the artifact will be altered as 1 ittle as possible by the treatment. (2) Preliminary analyses; thorough physical and chemical examinations will be undertaken when appropriate, to assess the state of the artifact and the identity of its material components. The data from such analyses will influence the choice of treatment. (3) Reversibility of treatment, a theoretical principle based on the actual properties of the treatment, the treatment materials used on the object, and the properties of the object itself. For example, a coating material, such as an acrylic, should be removable by adding the original solvent and should not undergo a chemical curing reaction which would make its removal damaging to the substrate. On the other hand, a cleaning treatment, such as applied to metal artifacts, is by nature irreversible and should be planned and undertaken with the utmost caution. These principles will be further discussed 1 ater in this chapter.

\section{THE ARTIFACTS}

\section{Sword Hilt}

A sword hilt hand guard from a saber has been identified as British-made, ca. 1821. Sword parts of this type were usually mass-produced by casting. It is 75\% complete, with parts of two of the smaller knuckle-bows missing (Fig. 26,C). The surface is heavily corroded with ferric oxide corrosion products and caliche mineral crusts. The corrosion has obscured most of the original surface of the metal. When corrosion proceeds, the metal surface is reduced below the 1 ine of its original extent, with the corrosion 1 ayer extending up above the surface line. The artifact also has areas of extensive mineralization of the metal. which forms fragile interleaved flakes. This mineralized metal may retain the shape and detail of the original surface, but the shape and detail are easily lost by removing the flakes. 


\section{Bayonet}

A Brown Bess musket bayonet (Fig. 28,b) has been identified as British-made. The Brown Bess muskets were manufactured by the Tower Armory and usually bore the Royal Tower proof mark of a crown. The bayonet was forged and then welded onto the shank and muzzle tube. The cross section of the blade is that of a trifoil. The proximal end attaches to the stud on the barrel by means of a slot in the bayonet tube.

The surface of the metal is eroded away and obscured by corrosion crusts and mineral metal scale over most of the surface of the artifact. The point is bent and rounded by corrosion. The tang end of the blade is eroded and almost completely mineralized.

\section{ANALYSIS}

Preliminary to treatment, the objects were examined with a portable industrial $X-r a y$ unit. The $f i 1 \mathrm{~ms}$ were exposed to $90 \mathrm{Kv}$ at $5 \mathrm{~mA}$ from 1.5 to 3 minutes. The surfaces under the corrosion layers are pitted to various extents. Tests with a bar magnet show that a substantial metal core does exist under the corroded surfaces on both artifacts except in the areas of lowest radiographic density.

None of the radiograms showed any signs of engraved or embossed designs, writing, or numbers on the artifacts.

Wet chemical tests indicated that chloride ions were not present. Calcium ions were present as components of the calcium carbonate (caliche) crusts.

\section{TREATMENT}

It was decided to clean the objects primarily by mechanical means, which would remove the most disfiguring, indurate crusts while leaving mineralized areas and areas of substantial metal intact. The color of the objects would remain the reddish brown to reddish orange of corroded iron with rough and uneven surface texture. The areas of active corrosion would be reduced, and coating with a clear acrylic after treatment would isolate the surface from the influences of atmospheric water vapor and oxygen. Electrolytic cleaning is often chosen as a treatment for historic archaeological iron al loy artifacts. This treatment usually removes all of the corrosion products down to the actual remaining metal. The surface is left with a grayish, metallic appearance and may be pitted further by the treatment. It must be monitored constantiy and the current readjusted to compensate for the lowered resistance as corrosion is removed. It is the author's opinion that electrolytic cleaning is unnecessary except for objects which contain harmful amounts of chloride ions (i.e., above 20-50 ppm). These artifacts will usual ly come from marine areas, and it is rare that soils from anywere other than in the immediate vicinity of a large body, or former body, of salt water will contain such high amounts of chlorine. In this case, therefore, electrolytic cleaning would not conform to the principles of conservation as stated in the Introduction. 
Figure 49 shows the mode of treatment chosen. The lower right quadrant is the schematic representation of what was done. The dense and hard corrosion 1 ayers were left above the "epidermis" and the actual metal core. The "epidermis" is the first corrosion 1 ayer to form on the object. It can be stable under ideal conditions, but there is usually a flaw in its surface or the surface of the underlying metal which, along with high moisture and oxygen in the presence of an electrolyte (i.e., soil), allows a galvanic cell to form. The "epidermis" usually contains whatever surface detail remains. The stabilization consists of the introduction of a solvented laquer-type acrylic resin.

A Columbus Cental Orbison 30 dental tool was used to remove the crusts. The Orbison operates by forcing compressed air over a rotor, which in turn vibrates a tuning fork in the instrument's handle. The cleaning tip is on a flat stage which translates the vibrations of the tuning fork into a rotatory, or orbital, motion. The instrument operates at approximately $2000 \mathrm{cps}$, at 10 to $15 \mathrm{psi}$. The air pressure can be adjusted at the control box to control the intensity of the tip motion. There are several tips which are interchangeable, ranging from a flat, blunt tip to a hooked point. Each type has its usage on various areas of the crust.

After the outer corrosion 1 ayers were removed, the surfaces were further cleaned with a $10 \% \mathrm{gm} / 1$ solution tetrasodium ethylenediametetraacetic acid (EDTA) in deionized water. The $\mathrm{pH}$ was lowered with the addition of ammonium acetate to $\mathrm{pH} 7$. The solution was applied with cotton swabs; this served to remove the looser, active corrosion products. The artifacts were rinsed with water and acetone and dried thoroughly.

During the mechanical treatment, there were several small areas where mineralized metal flakes were dislodged. Loss of these flakes altered the out 1 ine and the morphology of the artifacts. Wherever possible, the dislodged $f l a k e s$ were readhered to the artifact with Acryloid B-72, an ethyl methacryl ate copolymer.

After the cleaning treatments were completed, the artifacts were coated with a 3\% 1 iter/liter solution of Acryloid B-48N, a methy 1 methacrylate copolymer formulated for noncupreous metals. A small amount of microcrystaline wax was added to the solution in order to tone down the gloss of the acrylic.

\section{CONCLUSIONS}

As can be seen from comparing the before (Figs. 26,c; 28,b) and after (Fig. 50) photographs, details of the surface were revealed in both sword hilt and the bayonet without completely altering the appearance or composition of the surface. The objects have been stabilized; however, periodic close examinations should be undertaken to assure that the coating retains its structural integrity and that corrosion has not started again underneath it. The author would like to stress that not al1 of the details of the treatment have been given. The intention of this article is to explain the theory and practice of modern archaeological conservation and not as an 


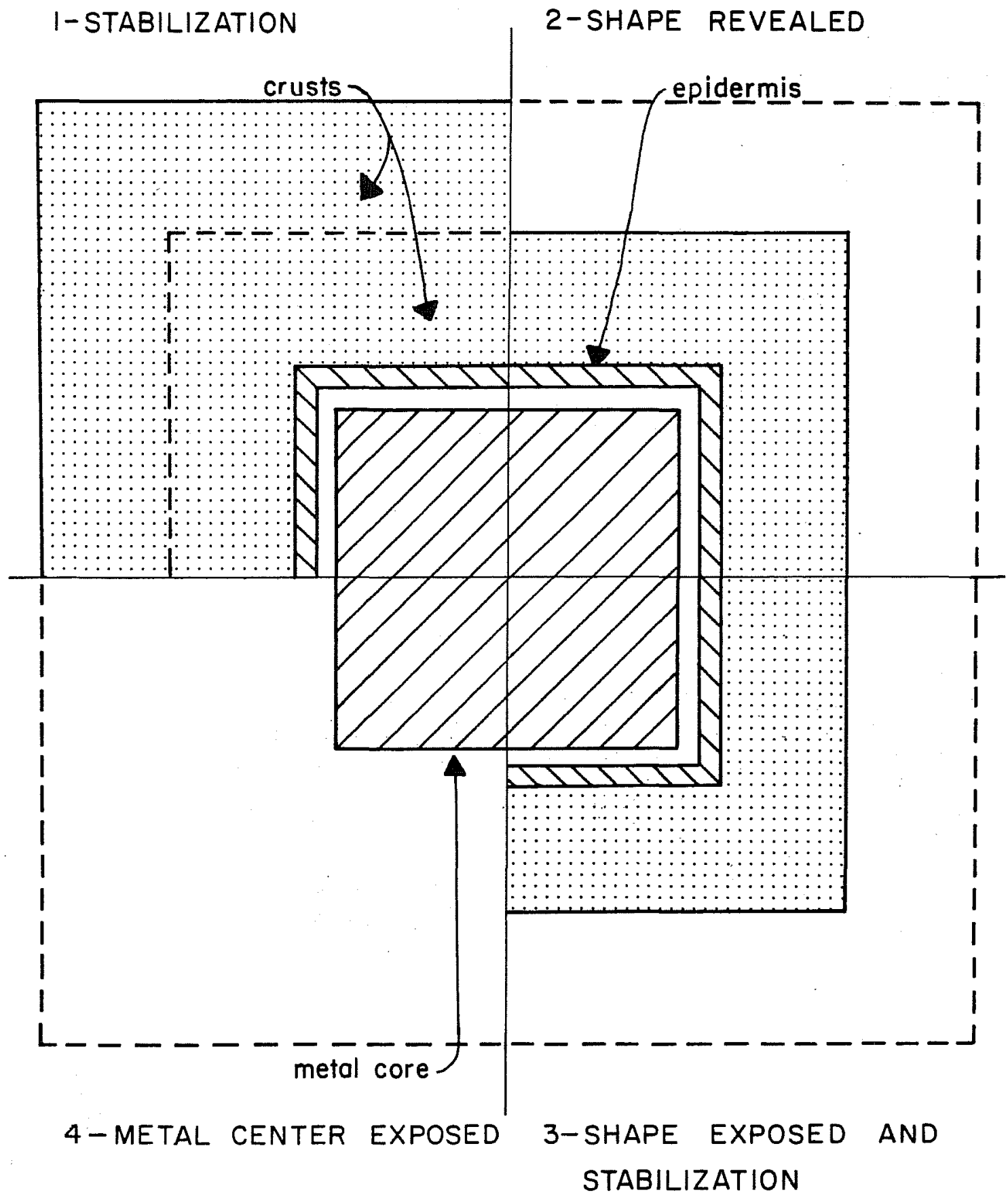

Figure 49. Options for Treating Corroded Metal. 

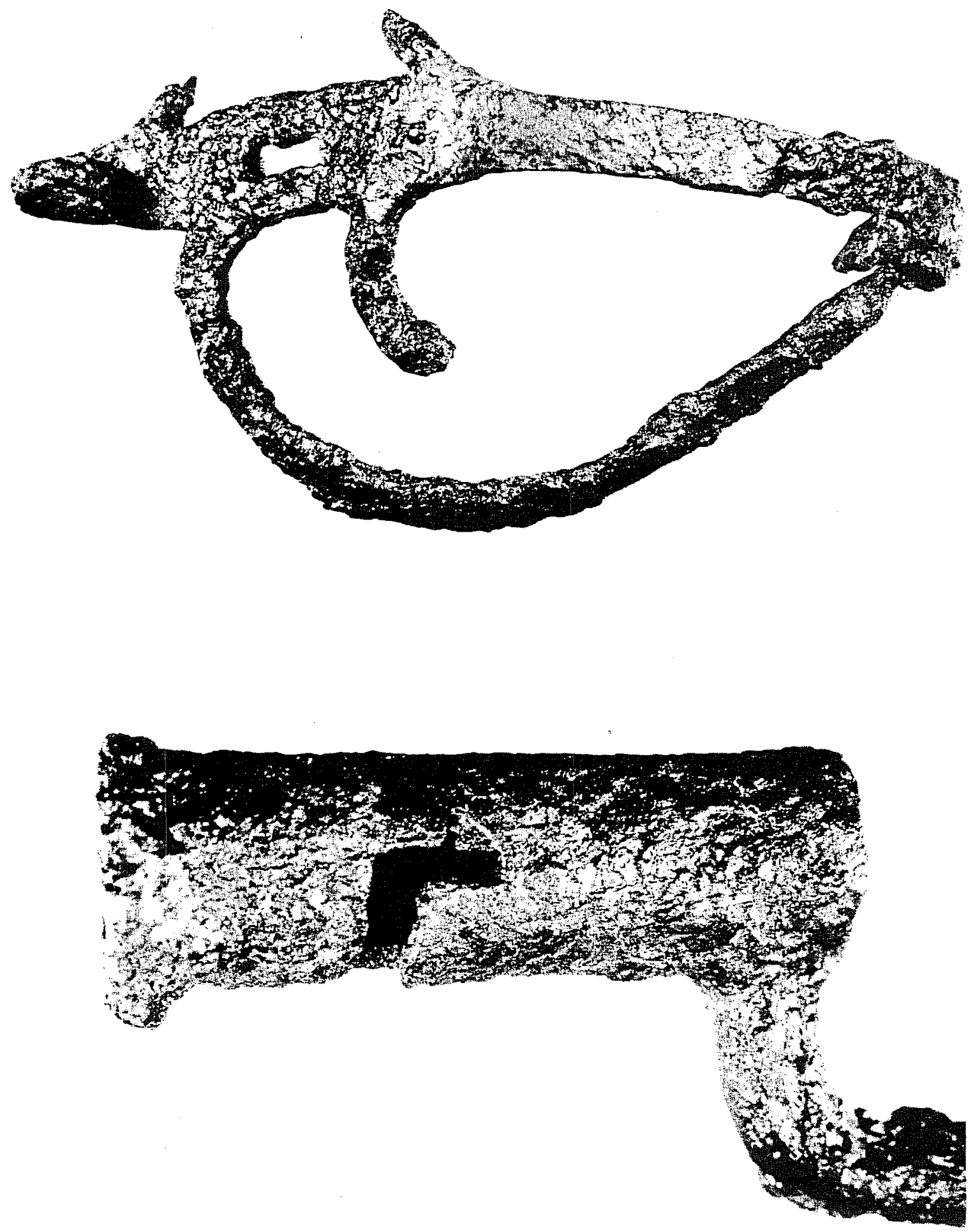

Figure 50. Specimens After Treatment. Upper, iron two-branch sword hilt from a British 1821 model light cavalry and artillery sword after cleaning and stabilization (length, $19.8 \mathrm{~cm}$ ); Tower, iron bayonet manufactured in England for use on a Brown Bess musket (outside diameter of shaft, $3.0 \mathrm{~cm}$ ). 
instructional manual on metal treatments. The author cannot accept responsibility for the improper application of the information contained in this article.

\section{ACKNONLEDGNENTS}

The author would like to thank Mr. Joe Fronek, formerly of the University of Texas at Austin Huntington Art Gallery Paintings Conservation Laboratory for providing the $X$-ray equipment and his assistance in photographing the radiographs; and the staff at Reinhart and Associated for the development of the film. 


\title{
CHAPTER 9 CONCLUDING REMARKS
}

\author{
Kenneth M. Brown
}

As this is being written, Texas has al ready entered its sesquicentennial year. Overcome by commemorative fever, manufacturers are offering a bewildering variety of Bowie knives, rifles, cups, medal1ions, belts, and other gear. Local historical societies and individual citizens are gearing up to sponsor community celebrations, special exhibits, and the like. The state's attics are being emptied of historical relics as various descendants donate family memorabilia--perhaps having nothing or 1 ittle to do with the Texas of 1836--to local museums. The historians are entering the fray, too, with historical symposia, new books, and public lectures. We can expect to see a blizzard of paper rivalling the snowfalls that harried the Mexican forces as they pressed northward in February of 1836. Much of this historical publishing will have 1 ittle concern with the events of 1836 . Others may deal with battles of the revolution, but are unlikely to offer much in the way of truly new information. Sometimes new documents are discovered, or documents long available only in manuscript form are published and become more widely known, but in all 1 ikelihood it seems that much of our sesquicentennial historicism will consist, in the main, of rehashing the historical facts as they are already known.

Meanwhile the Alamo, which in recent years has become a symbolic backdrop for almost every sort of modern vision quest, is being spruced up with new paint and polished brightwork. Hardly a day goes by without a newspaper photograph of some proponent of one or another cause, posing in front of the venerabie chape 1, presumably hoping for a measure of added legitimacy.

Faced with inescapable commercialization and trivialization of history, it is a 11 too easy to lose sight of the reality of the events themselves-until confronted, face-to-face, with the past. Documents such as the Travis letters, yellowed, stained, frayed from years of chancy curation, have the power to confront us with the past. Compeliing thoughts and observations frozen in time, like those of Isaac Millsaps, written on March 3 before the assault of the Alamo: "early this morning I watched the mexicans drilling just out of range they was marching up and down with such order... they have bright red \& blue uniforms and many canons... We have beef \& corn to eat but no coffee, bag I had fell off on the way here so it was all spilt" (Nevin 1975:96-97).

Archaeologists are confronted with the past on a daily basis. Usually it is a blurry and unyielding past measured in hesitant centuries and uncertain millennia. At times, though, the past breaks through to confront us with as much immediacy as can be found in the historian's yellowed documents--or perhaps even more. Then, we can measure the past on a daily basis, possibly an hourly basis. We can measure it by the laminated mud filling an abandoned entrenchment as a chilly rain fell in March 1836 . We can measure it by a hastily quenched fire huddled against the north wall of the trench, backed against the wall for protection against a frigid north wind and against hostile fire from the Alamo. And we can measure it with broken bayonets and impact-flattened musket bal1 $1 \mathrm{~s}$. 
It was serendipity, nothing more, that the particular date on which we began controlled excavations at La Villita Earthworks was just a couple of days short of 149 years after Santa Anna rode into Main Plaza on February 23 . 1836. But what serendipity! Taking stock of what we know and where we remain ignorant, we can say that it is very probable that the ditch we partial1y cleared at La Villita represents one of the entrenchments of Santa Anna's army during the assault on the Alamo. But what kind? Is it an artillery emplacement, an infantry position, a rifle pit? There are arguments to be considered for and against each function, as presented in Chapter 3. The balance of these arguments might favor the idea that it was an artillery emplacement, but the identification is hardly certain. It is perhaps safer to say simply that we do not know exactly what the function of the site was. Here the documents are, of course, silent. It is important that we remember what we do not know, lest we create our own archaeological mythology. Perhaps some of the answers will spring from further studies, perhaps not.

The 1 ayout of the siege work is rather unusual. Knowing that the Mexican officer corps would have been conversant with European military engineering principles, we looked for evidence of such knowledge as we dug, yet did not find it. This suggests the siege work may have taken ad hoc advantage of nearby standing buildings. Is the ditch L-shaped because it was wrapped around the corner of a building? Here we need documentary evidence to help us, but so far the evidence has not been forthcoming. What other buildings 1 ay nearby in 1836, and how did they structure the field of fire? Again, we need archival help with these questions. Construction of the Convention Center and renovation of La Vil1 ita has removed much of the evidence that archaeology might have provided.

There are many things we do not yet fully understand about the site. For example, how did such a 1 arge quantity of ceramic tableware come to be buried in the trench? In many ways the collection looks very different from the assemblages we are often accustomed to seeing. The sherds are 1 arger, there is 1 ittle evidence of use wear (abrasion, cut marks, and the 1 ike), there is a great deal of redundancy in the manufacturer (Davenport), the importer (Henderson and Gaines), and in the patterns represented. Does the collection represent household trash, or never-used goods that were being warehoused or retailed in San Antonio? How long a span of time is represented by the deposits in the trench? Was the trench filled rapidly or slowly, and did filling begin immediately after abandonment or at some 1 ater date? The interplay of these considerations is critical to our understanding of the site. If we can establish that most of the artifacts in the trench came to San Antonio near the time of the battle, and were thrown in the trench not long after the battle, we may establish a firm ending date for the age of the collection. The collection then becomes a useful chronological tool for assessing the age of other 19th-century San Antonio sites. On the other hand, we depend on the known ages of the artifacts to establish the age, and hence the historical significance of the trench. How can we avoid the inherent circularity of these arguments? The answer 1 ies in further careful study--studies of the spatial distribution of the sherds in the fill, archival studies of Henderson and Gaines and their role in supplying the frontier, and so forth. 
Analysis of the glassware reinforces many of the impressions registered in the ceramics. Much of the glassware seems to represent either expensive goods or containers for expensive imported goods. Does this contravene the notion that the artifacts represent household refuse from La Vil1ita, or are our impressions of the socioeconomic ranking of La Villita in error? Does any of the glassware represent unconsumed retail goods destroyed during any of the various invasions? Some of the wine bottle bases have abrasion, but even in our contemporary throwaway-container society, glass soda pop bottles are reused, and these too have basal abrasion. The struggle to relate the known history of glassmaking technology to the problem of dating the ditch fill is instructive. If, as we suggest here, the ditch fil1 is secondary refuse, there is no reason why the $f i 11$ in an 1836 ditch might not include artifacts both earlier and 1 ater than 1836. Both Berlandier (1980:291-292) and Martinez (1983:34) exp 1icitly state that La Villita escaped the disastrous flood that struck the town at 5 A.M. on July 5, 1819 (though Berlandier errs in giving the date as 1817), hence it would not be surprising to find sheet refuse with a lengthy pedigree in La Villita of the 1830s. Likewise, if the ditch stood open for any length of time, post-1836 artifacts might have been added to the sheet refuse in the interim. Unfortunately, the chronology of glassmaking technology is still poorly understood.

We also need to ask the significance of the bulky collection of animal bone (mostly beef) from the trench. Is this, too, household trash, or does it signify something else, such as the operation of a butcher shop nearby? Again, further studies of the bone are needed before we can attempt $\bar{a}$ resolution.

Pending a final report, then, what are the paramount lessons to be learned from La Villita Earthworks? One lesson, surely, is that it is through archaeology (combined with archival research) that new data on long-past events such as the battle of the Alamo will come. Another lesson, apparently still not understood by all, is that all of downtown San Antonio is a critical historical zone, one that should be approached with caution by those who alter the city and its substrate. We might also add that well over half a dozen other military positions associated with the two battles of the Alamo existed at some time, and some may still exist, as the example of La Villita shows. We know enough now to predict the locations of many of these with a fair degree of accuracy (see Fig. 14). Until we can prove that nothing remains, each of these locations should be regarded as a critical zone in which archaeological testing must proceed hand-in-hand with development. The feasibility of such cooperation has already been demonstrated by the Rivercenter project just a few blocks away. 


\section{REFERENCES CITED}

Berlandier, J. L.

1980 Journey to Mexico During the Years 1826 to 1834 . Translated by S. M. Ohlendorf, J. M. Bigelow, and M. M. Standifer. Texas State Historical Association in cooperation with the Center for Studies in Texas History, University of Texas at Austin.

Martinez, A.

1983 Letters from Gov. Antonio Martinez to the Viceroy Juan Ruiz de Apodaca. Edited by V. H. Taylor and F. D. Almaraz, Jr. Research Center for the Arts and Humanities, The University of Texas at San Antonio.

Nevin, D.

1975 The Texans. Time-Life Books, Inc., Alexandria. 
